\title{
WestVirginiaUniversity
}

THE RESEARCH REPOSITORY @ WVU

Graduate Theses, Dissertations, and Problem Reports

2014

\section{Grass component effect on soil physical properties in an organic crop rotation}

Emily Leslie Romano

Follow this and additional works at: https://researchrepository.wvu.edu/etd

\section{Recommended Citation}

Romano, Emily Leslie, "Grass component effect on soil physical properties in an organic crop rotation" (2014). Graduate Theses, Dissertations, and Problem Reports. 6527.

https://researchrepository.wvu.edu/etd/6527

This Thesis is protected by copyright and/or related rights. It has been brought to you by the The Research Repository @ WVU with permission from the rights-holder(s). You are free to use this Thesis in any way that is permitted by the copyright and related rights legislation that applies to your use. For other uses you must obtain permission from the rights-holder(s) directly, unless additional rights are indicated by a Creative Commons license in the record and/ or on the work itself. This Thesis has been accepted for inclusion in WVU Graduate Theses, Dissertations, and Problem Reports collection by an authorized administrator of The Research Repository @ WVU. For more information, please contact researchrepository@mail.wvu.edu. 


\title{
GRASS COMPONENT EFFECT ON SOIL PHYSICAL PROPERTIES IN AN ORGANIC CROP ROTATION
}

\author{
by \\ Emily Leslie Romano \\ Thesis submitted to the College of Agriculture, Natural Resources \& Design \\ at West Virginia University \\ in partial fulfillment for the requirements \\ for the degree of \\ Master of Science \\ in \\ Agronomy \\ Approved by \\ Eugenia Pena-Yewtukhiw, PhD, Committee Chair \\ Alan J. Sexstone PhD \\ Nicole L. Waterland PhD \\ Plant and Soil Sciences \\ Morgantown, West Virginia \\ 2014
}

Keywords: soil quality, organic agriculture, crop rotations

Copyright 2014 


\title{
Abstract \\ GRASS COMPONENT EFFECT ON SOIL PHYSICAL PROPERTIES IN AN ORGANIC CROP ROTATION
}

\author{
Emily Romano
}

In the past few decades, organic productions systems have become increasingly popular due to rising environmental awareness. Much research has been done on crop rotations and fertilization in conventional agricultural systems, but because organic management practices are often different from those in conventional systems, much is unknown about the effect of organic management practices on soil quality. Composted manure and a temporary grass component within an organic crop rotation may be capable of improving soil quality, and may be particularly important in the absence of synthetic chemical inputs. The objective of this research was to evaluate soil quality changes in two different rotations: with and without grass and at two rates of manure application. Variables measured were bulk density (BD), wet/dry aggregate stability (WA/DA Geometric Mean Diameter), bioavailable nutrients (Soil Organic Matter, N, P, $\mathrm{K}, \mathrm{Ca}, \mathrm{Mg}, \mathrm{Zn}$, TotN), and biomass. Additionally, the transition was examined from crop into temporary grass component, and from grass component back into crops. This research was conducted on an existing crop rotation experiment at the WVU Organic Farm in Morgantown, WV. Two rotations were studied: of four and seven year durations, with the same crop sequence (corn, soy, wheat, kale), and three years of orchard-grass/red clover added to the 7-year rotation. Two bi-annual manure rates: unmanured (U):0 and manured $(\mathrm{M}): 22.5 \mathrm{Mg} / \mathrm{ha}$ ) were applied to corn and wheat plots. Analysis of variance (ANOVA) was performed on the data. Measurements were taken in corn $(\mathrm{C})$ and kale $(\mathrm{K})$ plots, to represent the beginning and the end of the cropping cycle, and on first (Orchardgrass 5, or O5) and last (Orchardgrass 7, or O7) years of grass component.

Two years of data (2013 and 2014) show very similar results for both experiments. Results of Experiment 1 show that, within rotation, manure application nearly always significantly improved soil physical and chemical properties (e.g. for 2013, Bulk density (BD) 4-yr Manured (M): $1.09 \mathrm{Mg} / \mathrm{m}^{3}, 4-\mathrm{yr}$ Unmanured (U): $1.22 \mathrm{Mg} / \mathrm{m}^{3}, 7-\mathrm{yr} \mathrm{M:} 1.15 \mathrm{Mg} / \mathrm{m}^{3}, 7-\mathrm{yr} \mathrm{U}: 1.24 \mathrm{Mg} / \mathrm{m}^{3}$; Soil Organic Matter 4-yr M: 3.9\%, 4-yr U: 2.7\%, 7-yr M: 4.9\%, 7-yr U: 3.2\%; pH 4-yr M: 5.8, 4-yr U: 5.0, 7-yr M: 5.9, 7-yr U: 5.2; Phosphorus 4-yr M: 96.7mg/kg, 4-yr U: 19.7mg/kg, 7-yr M: $70.8 \mathrm{mg} / \mathrm{kg}$, 7-yr U: 26.2mg/kg; Total nitrogen 4-yr M: 2.7\%, 4-yr U: 1.7\%, 7-yr M: 2.9\%, 7yr U: $2.2 \%$ ). Corn and cowpea biomass were also higher in manured plots than in unmanured plots [Corn Biomass 4-yr M: 326g, 4-yr U: 248g, 7-yr M: 436g, 7-yr U: 253g; Cowpea Biomass 4-yr M: 8.63 Mg/ha, 4-yr U: 5.69 Mg/ha, 7-yr M: 9.47 Mg/ha, 7-yr U: 4.25 Mg/ha]. "Betweenrotation" results for manure application were very similar to those found within rotation.

A significant effect of crop was observed within rotation. Soil quality was often found to be higher in corn plots than in kale plots (e.g. DA-GMD 7-yr C: $5.1 \mathrm{~mm}, 7-\mathrm{yr} \mathrm{K}: 4.3 \mathrm{~mm}$; WAGMD 7-yr C: 4.9 mm, 7-yr K: 2.6 mm; SOM 4-yr C: 3.5\%, 4-yr K: 3.1\%; 7-yr C: 3.7\%, 7-yr K: 3.5\%; pH 7-yr C: 5.6, 7-yr K: 5.4; P 4-yr C: 86.9 mg/kg, 4-yr K: 29.6 mg/kg, 7-yr C: 72.9 mg/kg, 
7-yr K: $24.5 \mathrm{mg} / \mathrm{kg}$ ). This may be due to the fact that composted manure is added directly to corn plots, and not to kale plots. Interactions were observed between manure and crop.

The 7-yr rotation significantly improved bulk density (BD 4yr C: $1.7 \mathrm{Mg} / \mathrm{m}^{3}, 7 \mathrm{yr} \mathrm{C}: 1.3 \mathrm{Mg} / \mathrm{m}^{3}$ ), DA-GMD (4yr C: $3.9 \mathrm{~mm}, 7 \mathrm{yr}$ C: $5.1 \mathrm{~mm}$ ), WA-GMD (4yr C: $3.2 \mathrm{~mm}, 7 \mathrm{yr} \mathrm{C}: 4.9 \mathrm{~mm}$ ) and soil organic matter (SOM 4yr C: 3.1\%, 7yr C: 3.5\%), and appeared to have a protective effect of SOM. Regardless of crop, Total $\mathrm{N}$ was also higher in the 7-yr rotation (C: $2.8 \%, \mathrm{~K}: 2.2 \%$ ) than in the 4-yr rotation (C: $2.3 \%, \mathrm{~K}: 2.0 \%)$. The 7-yr rotation, however, did not always improve aggregate stability or plant available nutrients (WA-GMD 4yr K: 3.0mm, 7yr K: 2.7mm; P, 7-yr C: $72.9 \mathrm{mg} / \mathrm{kg}$, 4-yr C: $86.9 \mathrm{mg} / \mathrm{kg}$, and 7-yr K: $24.5 \mathrm{mg} / \mathrm{kg}$, and $4-\mathrm{yr} \mathrm{K}: 29.6 \mathrm{mg} / \mathrm{kg}$ ). Corn and cowpea biomass were highest in plots receiving the combination of the manure treatment and the 7-yr rotation treatment (e.g. Corn Biomass 4-yr M: 326g, 4-yr U: 248g, 7-yr M: 436g, 7-yr U: $253 \mathrm{~g}$ ). An interaction was found between manure addition and rotation.

In 2013, results of Experiment 2 show the effect of the transition into and out of the temporary grass component. The transition from crops into grass showed an improvement in soil quality (e.g. BD K: 1.14, O5: 1.19; DA-GMD K: 4.4mm, O5: 6.4mm; Calcium K: $1728 \mathrm{mg} / \mathrm{kg}$, O5: $2015 \mathrm{mg} / \mathrm{kg}$ ). This improvement reversed during the transition out of the temporary grass component (e.g. BD 07: 1.24, C: 1.13; DA-GMD K: 6.1mm, O5: 5.1mm; Calcium O7: $2135 \mathrm{mg} / \mathrm{kg}, \mathrm{C}: 1938 \mathrm{mg} / \mathrm{kg}$ ). These changes reflect a pause in tillage and the effect of the grass component, and subsequent resume in tillage.

This research supports the use of manure application and the use of a temporary grass component in an organic rotation to improve soil physical quality. The research also increases the understanding of the effect of a grass component within organic rotations on soil quality, and would benefit from additional organic long-term rotational research. 


\section{Table of Contents}

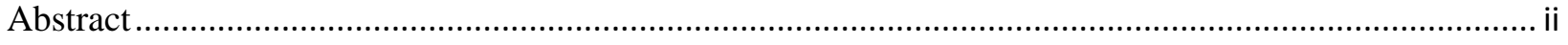

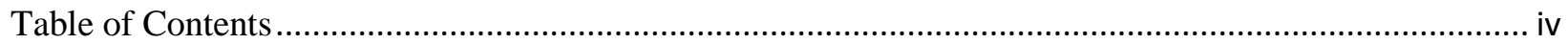

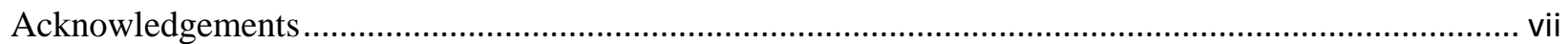

CHAPTER 1. INTRODUCTION AND JUSTIFICATION ................................................................. 1

CHAPTER 2. LITERATURE REVIEW ………............................................................................. 3

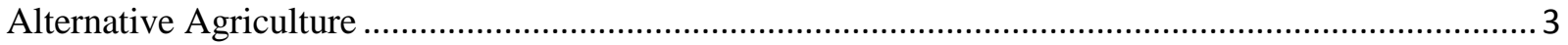

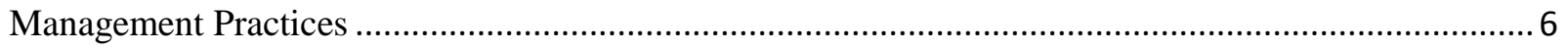

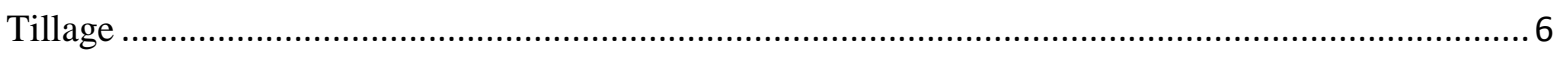

Crop Rotations

Temporary Grass Component in a Rotation............................................................................... 10

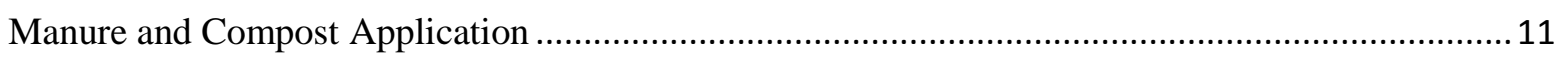

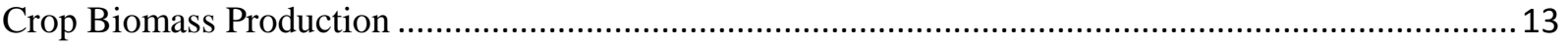

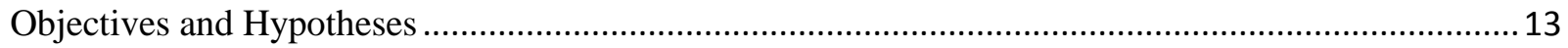

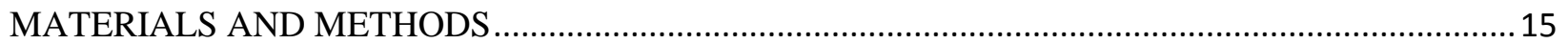

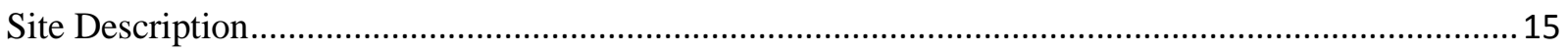

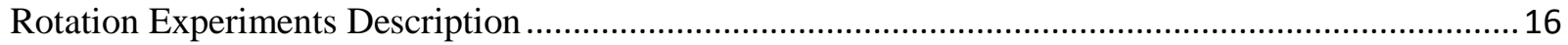

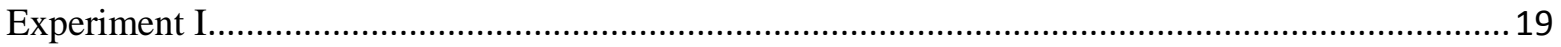

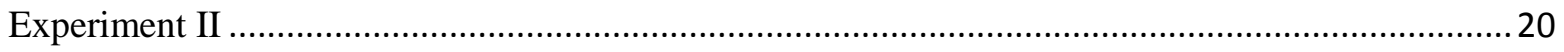

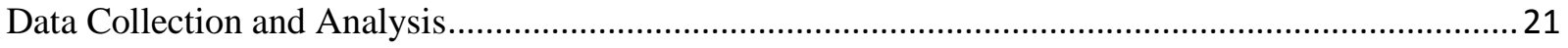

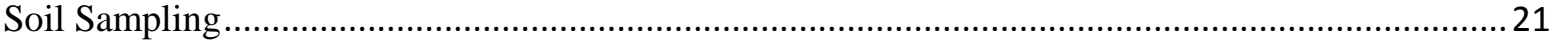

Soil Sample Processing: Methodology and Analysis..................................................................... 21

Biomass Sampling, Methodology, and Analysis ......................................................................... 23

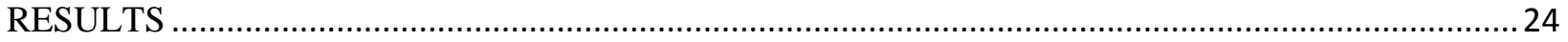

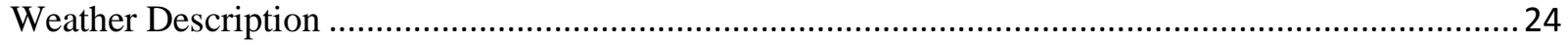

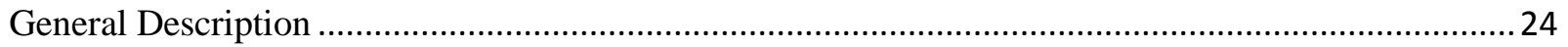

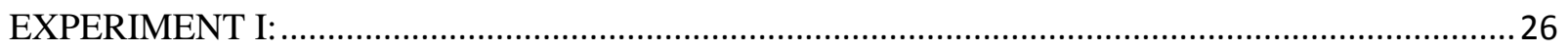

2013 Within-Rotation Effect of Manure and Crop on Physical and Chemical Quality .....................26

Manure effect within rotation type (4-yr and 7-yr) ................................................................. 26

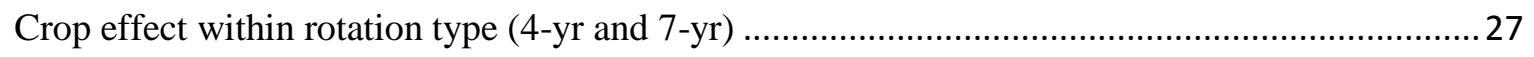

Interactions within rotation type (4-yr and 7-yr) between manure and crop ..............................28 
2013 Between-Rotation Effect of Manure and Rotation on Physical and Chemical Quality, and

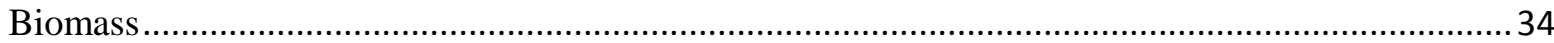

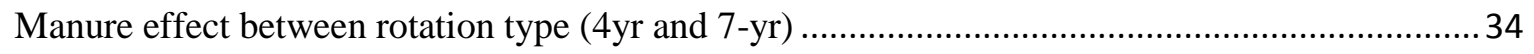

Rotation effect between rotation type (4yr and 7-yr) within crop component ..............................35

Interactions between manure and rotation type within crop component ….................................. 36

2014 Within-Rotation Effect of Manure and Crop on Physical and Chemical Quality ..................... 42

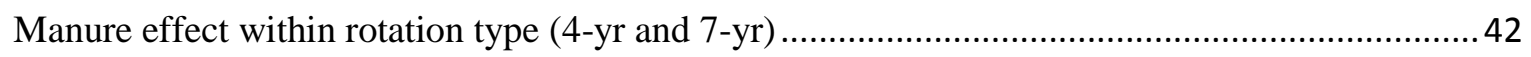

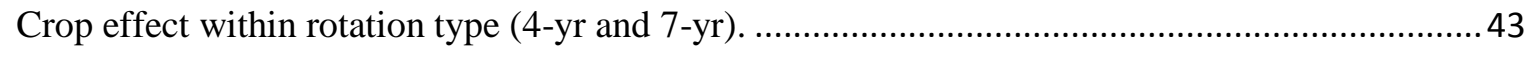

Interactions between manure and crop within rotation type (4-yr and 7-yr)............................... 44

2014 Between-Rotation Effect of Manure and Rotation on Physical and Chemical Quality, and

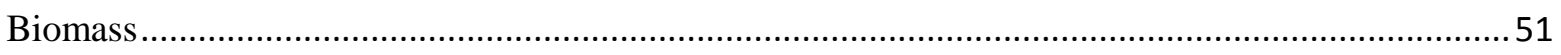

Manure effect between rotations, within first and last crop in the sequence. ................................51

Rotation type effect between rotations, within first and last crop in the sequence. .......................52

Interactions between manure and rotation, within first and last crop in the sequence...................53

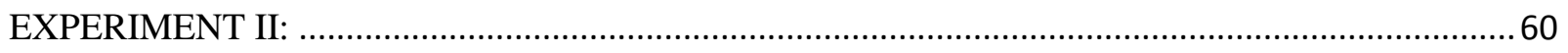

2013 Within-Rotation Effect of Manure and Crop on Transition into and out of Temporary Grass

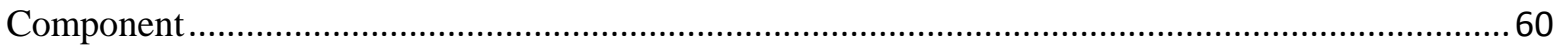

Manure effect within rotation on transition into and out of grass component .............................61

Crop effect within rotation on transition into and out of grass component..................................61

Interaction between manure and crop on transition into and out of grass component ....................62

2014 Within-Rotation Effect of Manure and Crop on Transition into and out of Temporary Grass

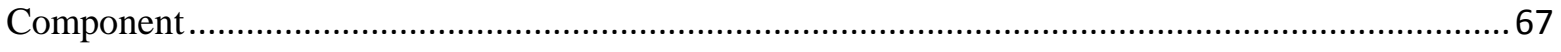

Manure effect within rotation on transition into and out of grass component ..............................67

Crop effect within rotation on transition into and out of grass component.................................6 68

Interaction between manure and crop on transition into and out of grass component ....................69

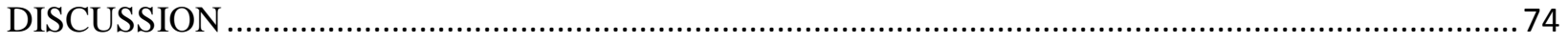

2013 Within Rotation Effect of Manure and Crop on Physical and Chemical Quality ...................... 74

Manure effect within rotation type (4-yr and 7-yr) ............................................................... 74

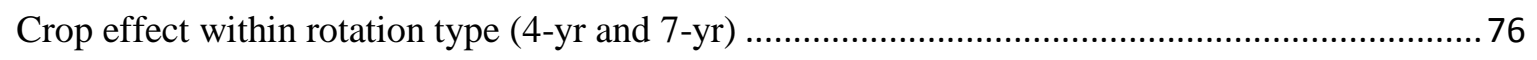

Interactions within rotation type (4-yr and 7-yr) between manure and crop ...............................77

2013 Between-Rotation Effect of Manure and Rotation on Physical and Chemical Quality, and

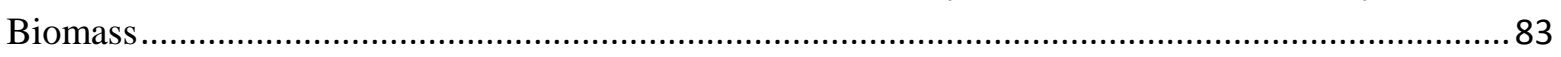

Manure effect between rotation type (4yr and 7-yr) …....................................................... 83 


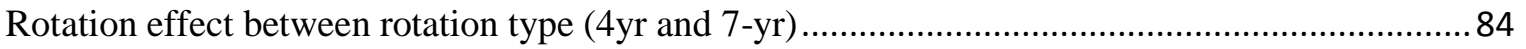

Interactions between manure and rotation, between rotation type (4yr and 7-yr) ........................86

2014 Within Rotation Effect of Manure and Crop on Physical and Chemical Quality ...................... 89

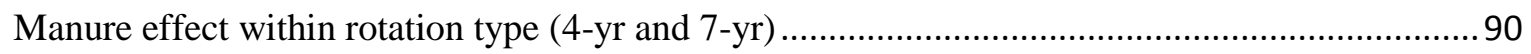

Crop effect within rotation type (4-yr and 7-yr)..................................................................... 90

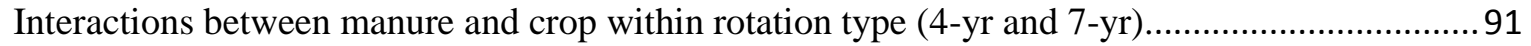

2014 Between-Rotation Effect of Manure and Rotation on Physical and Chemical Quality, and

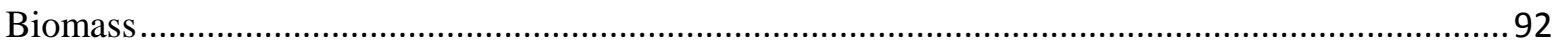

Manure effect between rotations, within first and last crop in the sequence. ...............................93

Rotation type effect between rotations, within first and last crop in the sequence. .......................94

Interactions between manure and rotation, within first and last crop in the sequence...................95

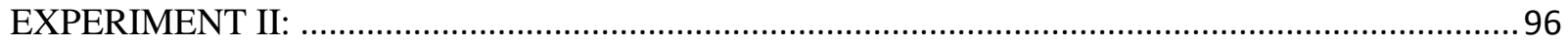

2013 Within-Rotation Effect of Manure and Crop on Transition into and out of Temporary Grass

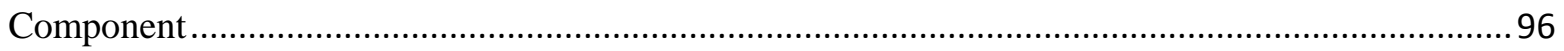

Manure effect within rotation on transition into and out of temporary grass component..............97

Crop effect within rotation on transition into and out of temporary grass component ...................97

Interaction between manure and crop on transition into and out of temporary grass component...99

2014 Within-Rotation Effect of Manure and Crop on Transition into and out of Temporary Grass

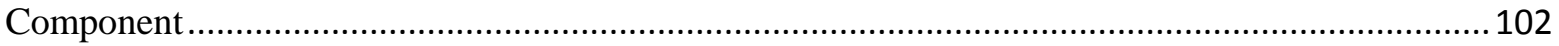

Manure effect within rotation on transition into and out of temporary grass component ............. 102

Crop effect within rotation on transition into and out of temporary grass component ................ 103

Interaction between manure and crop on transition into and out of temporary grass component. 104

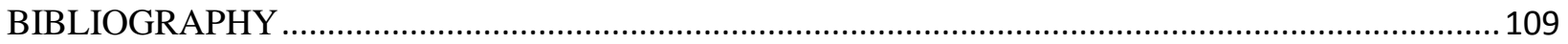

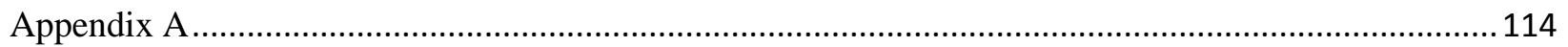

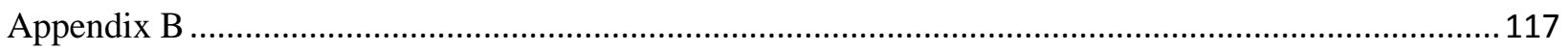

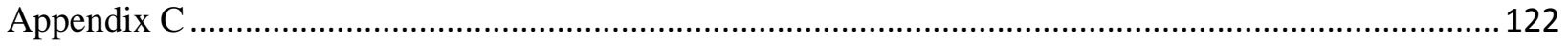




\section{Acknowledgements}

First I would like to thank the chair of my committee, Dr. Eugenia Pena-Yewtukhiw, for the incredible amount of time and support she invested in me during my time as her student. She is one of the most scientifically competent human beings I have ever known, and her passion for good science is a great asset to all who work with her. I could not have asked for a better mentor. My committee members, Dr. Alan Sexstone and Dr. Nicole Waterland, were also extremely valuable mentors to me for my research and my path through graduate school; it has been a real joy to work with them. I'd also like to thank Dr. William Bryan, Dr. Domingo Mata-Padrino, Dr. John Grove (University of Kentucky), Dr. Jim Kotcon, Dr. Dave Belesky, Dr. Barton Baker, and Mr. Marvin Clark. These members of faculty and staff in the Division of Plant and Soil Sciences provided expertise and insight, and served as valuable sounding boards. They designed, initiated, maintained, and informed me of every detail of the crop rotation, and without their careful and consistent work, it would not exist.

Several students helped with lab processing and field sampling: Caleb Griffin, Seth Adams, Kelby Fetter, Abby Facemyer, and Brittany Parks. I am so grateful for how careful they were with the samples, and how eager they were to learn and teach techniques. I will really miss working with each of them.

I'd like to thank my mother and stepfather (Alison Romano and Joseph McKeon), and my father (Dr. Joseph Romano) for their love and support throughout my pursuit of this degree. Most of all I'd like to thank my fiancé, Matthew Fouty, for supporting my career, being my late-nightgrilled-cheese-preparer, and for being my most persistent cheerleader. How lucky I am, to have found him so early in my life. 


\section{LIST OF TABLES}

Table 1.Taxonomic Classification of Soil Series in Experimental Area................... 16

Table 2. Summary of temperature, precipitation and growing degree days (GDD) for 20122014

Table 3: Within-rotations (4-yr and 7-yr) main effects of manure and crop on 2013 soil physical quality indicators

Table 4. Within-rotations (4-yr and 7-yr) main effects of manure and crop on 2013 stratified soil $\mathrm{pH}(\mathrm{KCl})$ and soil organic matter $(\mathrm{SOM})$

Table 5. Within-rotations (4-yr and 7-yr) main effects of manure and crop on 2013 stratified soil test phosphorus (STP) and soil test potassium (STK)....

Table 6. Within-rotations (4-yr and 7-yr) main effects of manure and crop on 2013 stratified soil test calcium (STCa) and soil test magnesium (STMg).

Table 7. Within-rotations (4-yr and 7-yr) main effects of manure and crop on 2013 stratified soil test zinc $(\mathrm{STZn})$ and total nitrogen $(\mathrm{Tot} N)$.

Table 8: 2013 Between-Rotations main effects of manure and rotation (4-yr and 7-yr) on soil physical quality indicators under the first (corn) and last (kale) crop component of the rotation.

Table 9. Main effects of manure and rotation (4-yr and 7-yr) on stratified 2013 stratified soil $\mathrm{pH}(\mathrm{KCl})$ and soil organic matter (SOM) under the first (corn) and last (kale) crop component of the rotation.

Table 10. Main effects of manure and rotation (4-yr and 7-yr) on 2013 stratified soil test phosphorus (STP) and soil test potassium (STK) under the first (corn) and last (kale) crop component of the rotation.

Table 11. Main effects of manure and rotation (4-yr and 7-yr) on stratified 2013 soil test calcium (STCa) and soil test magnesium (STMg) under the first (corn) and last (kale) crop component of the rotation

Table 12. Main effects of manure and rotation (4-yr and 7-yr) on 2013 stratified soil test zinc (STZn) and total nitrogen (TotN) under the first (corn) and last (kale) crop component of the rotation.

Table 14. Effect of the 2013 manure and rotation treatments on cowpea and weed biomass.

Table 15. Within-rotations (4-yr and 7-yr) main effects of manure and crop on 2014 soil physical quality indicators 
Table 16. Within-rotations (4-yr and 7-yr) main effects of manure and crop on 2014

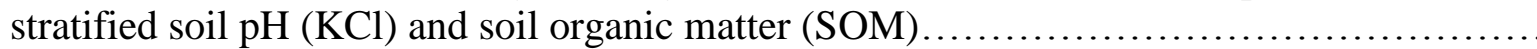

Table 17. Within-rotations (4-yr and 7-yr) main effects of manure and crop on 2014 stratified soil test phosphorus (STP) and soil test potassium (STK)...

Table 18. Within-rotations (4-yr and 7-yr) main effects of manure and crop on 2014 stratified soil test calcium (STCa) and soil test magnesium (STMg).

Table 19. Within-rotations (4-yr and 7-yr) main effects of manure and crop on 2014 stratified soil test zinc (STZn) and total nitrogen (TotN).

Table 20. 2014 Main effects of manure and rotation (4-yr and 7-yr) on soil physical quality indicators under the first (corn) and last (kale) crop component of the rotation...

Table 21. Main effects of manure and rotation (4-yr and 7-yr) on stratified 2014 stratified soil $\mathrm{pH}(\mathrm{KCl})$ and soil organic matter (SOM) under the first (corn) and last (kale) crop component of the rotation.

Table 22. Main effects of manure and rotation (4-yr and 7-yr) on 2014 stratified soil test phosphorus (STP) and soil test potassium (STK) under the first (corn) and last (kale) crop component of the rotation.

Table 23. Main effects of manure and rotation (4-yr and 7-yr) on stratified 2014 soil test calcium (STCa) and soil test magnesium (STMg) under the first (corn) and last (kale) crop component of the rotation.

Table 24. Main effects of manure and rotation (4-yr and 7-yr) on 2014 stratified soil test zinc (STZn) and total nitrogen (TotN) under the first (corn) and last (kale) crop component of the rotation.

Table 25. Means, standard deviations, and coefficient of variation for the 2014 corn biomass per plant by treatment.

Table 26. Effect of the 2014 manure treatment on cowpea, weed, and total biomass, 4-yr rotation.

Table 27. Transition from Grass into Crop Component, and Crop Component into Grass: Effect of manure and plant species on 2013 soil physical properties

Table 28. Transition from Grass into Crop Component, and Crop into Grass Component: Effect of manure and plant species on 2013 stratified soil $\mathrm{pH}(\mathrm{KCl})$ and soil organic matter (SOM)

Table 29 Transition from Grass into Crop Component, Crop into Grass Component: Effect 
of manure and plant species on 2013 stratified soil $\mathrm{P}(\mathrm{mg} / \mathrm{kg}), \mathrm{K}(\mathrm{mg} / \mathrm{kg}) \ldots \ldots \ldots \ldots \ldots \ldots$

Table 30. Transition from Grass into Crop Component, and Crop into Grass Component: Effect of manure and plant species on 2013 stratified soil $\mathrm{Ca}(\mathrm{mg} / \mathrm{kg})$ and TotN

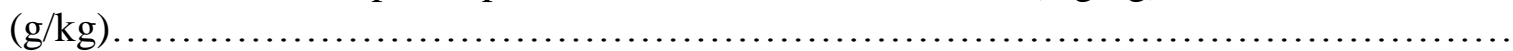

Table 31. Transition from Grass into Crop Component, and Crop Component into Grass:

Effect of manure and plant species on 2014 soil physical properties

Table 32. Transition from Grass into Crop Component, and Crop into Grass Component: Effect of manure and plant species on 2014 stratified soil $\mathrm{pH}(\mathrm{KCl})$ and soil organic matter (SOM)

Table 33. Transition from Grass into Crop Component, and Crop into Grass Component: Effect of manure and plant species on 2014 stratified soil $\mathrm{P}(\mathrm{mg} / \mathrm{kg})$ and $\mathrm{K}(\mathrm{mg} / \mathrm{kg}) \ldots \ldots \ldots \ldots$

Table 34. Transition from Grass into Crop Component, and Crop into Grass Component: Effect of manure and plant species on 2014 stratified soil Ca $(\mathrm{mg} / \mathrm{kg})$ and TotN $(\mathrm{g} / \mathrm{kg}) \ldots \ldots$

Table 35. Effect of manure treatment and year into the transition on grass biomass in 2013 and 2014 


\section{LIST OF FIGURES}

Figure 1a. Comparison of like-crop components between rotations to determine effect of temporary grass component and manure application...................................

Figure 1b. Comparison of first (corn) and last (kale) crop component within each rotation to determine the effect of crop and manure application.

Figure 2. Transition from cropping cycle $(\mathrm{K}=$ kale) into orchardgrass component $(\mathrm{OG})$, and then from $\mathrm{OG}$ to cropping cycle $(\mathrm{C}=$ corn $)$.

Figure 3. Spatial distribution of the soil map units and rotation study plots are separated by blocks.

Figure 4. Plots in the 4-yr rotation are shown in green. Plots in the 7-yr rotation are shown in purple

Figure 5. Figure 5. Interactions for bulk density (BD, 0-5mm) between manured and unmanured plots within rotation.

Figure 6. Interactions for dry aggregate stability geometric mean diameter (DA-GMD, 0$5 \mathrm{~cm}$ ) between manured and unmanured plots within rotation

Figure 7. Interactions for soil organic matter (SOM, $0-5 \mathrm{~cm}$ ) between manured and unmanured plots within rotation

Figure 8. Interactions for $\mathrm{pH}(0-5 \mathrm{~cm})$ between manured and unmanured plots within rotation

Figure 9. Interactions for soil test phosphorus (STP, $0-5 \mathrm{~cm}$ ) between manured and unmanured plots within rotation

Figure 10. Interactions for soil test potassium (STK, 5-10cm) between manured and unmanured plots within rotation

Figure 11. Interactions for soil test calcium (STCa, $0-5 \mathrm{~cm}$ ) between manured and unmanured plots within rotation

Figure 12. Interactions for soil test magnesium (STMg, $0-5 \mathrm{~cm}$ ) between manured and unmanured plots within rotation

Figure 13. Interactions for soil test magnesium $(\mathrm{STMg}, 5-10 \mathrm{~cm})$ between manured and unmanured plots within rotation

Figure 14. Interactions for soil test zinc (STZn, $0-5 \mathrm{~cm}$ ) between manured and unmanured plots within rotation 
Figure 15. Interactions for soil test zinc (STZn, 5-10cm) between manured and unmanured

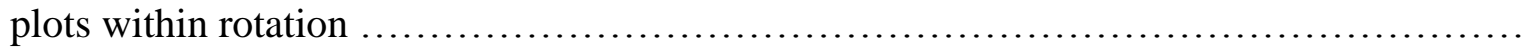

Figure 16. Interactions for total nitrogen $($ TotN, $0-5 \mathrm{~cm})$ between manured and unmanured plots within rotation

Figure 17. Interactions for bulk density $(\mathrm{BD}, 0-5 \mathrm{~cm})$ between manure and rotation between rotations (4-yr and 7-yr)

Figure 18. Interactions for wet aggregate geometric mean diameter (WA-GMD, 0-5cm)

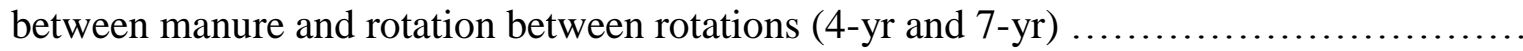

Figure 19. Interactions for $\mathrm{pH}(0-5 \mathrm{~cm})$ between manure and rotation between rotations $(4-\mathrm{yr}$ and 7-yr)

Figure 20. Interactions for $\mathrm{pH}(5-10 \mathrm{~cm})$ between manure and rotation between rotations (4yr and 7-yr)

Figure 21. Interactions for soil test phosphorus (STP, $0-5 \mathrm{~cm}$ ) between manure and rotation between rotations (4-yr and 7-yr)

Figure 22. Interactions for bulk density $(\mathrm{BD}, 0-5 \mathrm{~cm})$ between manure and crop during transition into and out of temporary grass component

Figure 23. Interactions for dry aggregate geometric mean diameter (DA-GMD, 0-5cm) between manure and crop during transition into and out of temporary grass component ...

Figure 24. Interactions for soil organic matter (SOM, 0-5cm) between manure and crop during transition into and out of temporary grass component

Figure 25. Interactions for $\mathrm{pH}$ between manure and crop during transition into and out of temporary grass component

Figure 26. Interactions for soil test phosphorus (STP, 0-5cm) between manure and crop during transition into and out of temporary grass component 


\section{CHAPTER 1. INTRODUCTION AND JUSTIFICATION}

Soil quality and environmental health are dependent upon the agricultural practices selected for a specific production system. In the past half-century, agricultural production systems have evolved to become highly mechanized and highly dependent upon external chemicals input systems with their own management strategies. These new management strategies, called conventional or traditional management practices, may have resulted in loss of soil organic matter (SOM) and nutrients, soil erosion, and increasing vulnerability of crops to pests and extreme weather (Duiker, 2006). It is believed that non-conventional or alternative management systems such as organic production systems are capable of solving problems caused by traditional synthetic chemical-dependent agriculture, notably those related to poor soil quality and harmful inputs (Pimentel et al., 2005). Increasing environmental awareness leads many farmers to consider transition to organic agriculture; the more these "new" or "alternative" systems are adopted, the greater the need for a solid scientific understanding of their effect upon soil quality.

Soil quality in the agricultural context is defined as the ability of the soil to maintain crop production and productivity over time. It is evaluated, monitored, and characterized through soil quality indicators, such as bulk density, $\mathrm{pH}$, soil organic carbon (SOC), wet and dry aggregate stability, plant yield/biomass, and measures of soil biological activity. Organic farming practices are believed to improve variables that reflect soil quality, such as high biodiversity, SOC, pools of stored nutrients (Clark et al., 1998; Pimentel et al., 2005), enhanced soil aggregation (Sainju et al., 2003; Green et al. 2005), and soil structure (Riley et al., 2008). Although crop yields from organic systems are lower than those of conventional/ traditional systems, the latter are believed to be ecologically deleterious, and encourage resistance of pests, weeds, and disease (Pimentel et al., 2005).

In the absence of synthetic fertilizers and pesticides, organically-managed systems rely on a variety of strategies to maintain production and soil quality. These strategies are included in what are referred to as Best Management Practices (BMPs). BMPs are a broad array of land management techniques which maintain, preserve, improve and restore soil and water quality. In agricultural systems, these practices are implemented to increase production, ground cover 
(White, 2006), and to manage environmental and climatological risks. BMPs include crop rotations, reduced tillage, manure, fertilizer and compost application, irrigation, planting of legumes and cover crops, green manures, and livestock grazing (Chirinda et al., 2010; Baldwin, 2006).

Crop rotations are common in agricultural systems in general, but are essential in organic agricultural systems. Crop rotation cycles are defined by the crop composition (type) and the length of time (duration) over which each crop species remains in the field. The summation of all the individual crop length of times is called the rotation duration or cycle length. Short two or three annual crop rotation cycles may reduce the need for agrochemical application. Shorter rotation cycles do not include forage crops or multi-year pasture sequences, which may increase and maintain soil organic matter (SOM) (Baldwin, 2006; NRAES, 2006). Other types of rotation cycles include periods of fallow, during which mineralization of SOM continues, reducing the amount of this essential component. A successful rotation cycle alternates between leguminous and non-leguminous crops, high- and low-requirement crops, deep-rooted and shallow-rooted crops, and may also include a grass component for sod or pasture. Green manures or cover crops may be planted, and incorporated into the soil before seeding a cash crop. If a rotation is maintained, it has the potential to increase levels of SOM and improve soil physical properties over time (Baldwin, 2006).

Including a temporary grass component could be important in organic crop rotations for maintaining soil structure, controlling pests and weeds, and enhancing nutrient cycling (Chirinda et al., 2010; Riley et al., 2008). While it is generally accepted that a grass component is beneficial to a rotation cycle, existing research on this matter has mainly been done on conventionally managed rotations. Therefore, implications for organic rotations may only be inferred (NRAES, 2006).

This study seeks to identify and measure changes in soil physical properties due to the presence or absence of a grass component in an organic crop rotation. The findings of this study could improve our understanding of the sustainability of organic agriculture, and better inform Best Management Practices (BMPs) available to organic farmers. 


\section{CHAPTER 2. LITERATURE REVIEW}

\section{Alternative Agriculture}

In the past fifty years, social and ecological problems caused by conventional agriculture have created a need for improved production systems. Sustainable agriculture can be defined as a broad set of management practices and methods which increase and maintain food production with the additional goals of enhancing environmental quality, resource efficiency, sustaining economic viability of farm operations, reduced chemical dependence, and social justice (USDA, 2009). Alternative methods within sustainable agriculture are diverse, and no single method is a perfect solution. These practices include aquaponics, ecological pest management, permaculture, agroforestry, and organic production. The ideal practice would produce good crop yields, be economical, and minimize ecological impact.

Organic systems are in the spotlight of sustainable agriculture. They rely upon BMPs such as conservation tillage, crop rotations, cover crops, green manures, multi-year pasture sequences, livestock grazing, and application of manure and crop residue as fertilizer (White, 2006). These practices have been reported to support soil structural stability, efficient nutrient cycling, and soil biodiversity without the use of synthetic pesticides and fertilizers (Chirinda et al., 2010).

Organic Certification is an option for organic producers, which allows products to be sold, labeled, and represented as organic (USDA, 2009). Certification is an important distinction from "organic practices" because it ensures compliance by the farmer to general and specific management practices, such as preserving natural resources and biodiversity, supporting animal health and welfare, providing animal access to outdoors so animals can exercise their natural behaviors, use of approved materials only, non-use of genetically modified ingredients, annual onsite inspections, and separate storage of organic and non-organic food and materials (USDA, 2009). Certification requires that land used to produce food or fiber be managed in compliance with the USDA standards for three years prior to certification.

Organic practices tend to increase SOC which enhances soil physical properties, specifically aggregate stability and water holding capacity (Green et al., 2005; Fenton et al., 1999; Siegrist et al., 1998; Riley et al., 2008). Aggregate stability has been reported to be 1060\% higher in organic systems (Mäder et al., 2002). These benefits might be expected in systems which improve SOC, because aggregates are stabilized by organic matter; however sometimes 
only slight differences are observed compared to conventional systems (Mäder et al., 2002). Six et al. (2001) reported that different organic matter percentages can be found in different aggregate fractions when subjected to slaking. Microaggregates appear to be stabilized by more persistent or recalcitrant SOM, while macroaggregates are composed of microaggregates bound by younger organic materials, roots and hyphae (Yamashita et al., 2006; Arshad et al., 2004; Freixo et al., 2002). Fine, inter-aggregate organic material appears to be more altered by microbial processes than coarse inter-aggregate organic material (Six et al., 2001).

A successful organic management plan will mitigate crop and soil vulnerability due to management practices. However, in the absence of herbicides, organic systems rely heavily on tillage and cover crops to control weeds (Liebman \& Davis, 2000). Tillage-induced aggregate destruction may negate the benefits of BMPs by accelerating SOM decomposition, aggregate breakage, and increasing the risk of erosion (Green et al., 2005; Chan et al., 1996). The deleterious effect of tillage on soil structure in organic systems may impact the sustainability of this production system. Few organic studies are long-term trials, although those in existence report some environmental benefits (Drinkwater et al., 1998; Mäder et al., 2002; Robertson et al., 2000).

Most of the existing research on soil physical property changes due to management practices in cropping systems focuses on conventional agriculture systems. This research could have implications for organic agriculture, despite the differences between conventional and organic production systems. Physical processes in the soil depend upon its chemical and biological properties, which may be dramatically different between production systems. For example, inorganic fertilizers have the potential to speed breakdown of organic residues, which has been reported to reduce aggregate stability (Chirinda et al., 2010; Mäder et al., 2002). Studies are needed to measure soil physical and chemical properties as indicators of soil quality in organic systems, including bulk density, aggregate stability, aggregate size distributions, and total C, N, and P (Green et al., 2005).

Primary productivity and yield are additional measurements used as proxies to characterize soil quality. Because conventional agriculture produces higher yields, existing research on organic systems tends to measure yield, or net primary productivity (Bell et al., 2012; Acharya et al., 2004). Yield is affected by many variables, but as a surrogate for soil quality, it has implications for the economics of organic farming. Yields may be lower in some 
organic systems, but yields from a high quality organically managed soil may eventually match those of conventional systems, and will be less dependent upon chemical inputs (Chirinda et al., 2010; Mäder et al., 2002).

Higher nutrient use efficiency has been reported in organic systems, as exhibited by large reductions in inputs paired with lesser reductions in mean crop yield (Mäder et al., 2002).

A delay is present between time of organic amendment application and the availability of nutrients to plants, due to the time required for organic materials to decompose and be mineralized in the soil. This delay is not present in conventional systems where synthetic fertilizers are applied (Liebman \& Davis, 2000). If applied at the right time, this "slow-release" fertilizer effect of organic materials may increase the likelihood that nutrients will be utilized by a crop, rather than being present in excess and consequently leached or volatized. Organic systems also exhibit slightly higher pH than conventional systems (Mäder et al., 2002), which is associated with higher levels of SOM.

A system that relies upon high levels of SOM and incorporates a greater amount of residues into the soil is likely to exhibit higher soil carbon sequestration (Drinkwater et al., 1998). While the species of the plant has been shown to have little effect on the amount of carbon sequestered, residue composition and quality appear to be very important. It has been shown that more carbon from applied manure persists in the soil than carbon from the application of crop residues. This may be due to the partially decomposed nature of manure and the chemical recalcitrance of its compounds (Drinkwater et al., 1998).

Ideally, organic agriculture will have a beneficial impact on ecological factors by building soil fertility and supporting biodiversity. A positive correlation has been found between aggregate stability and both microbial and earthworm biomass (Mäder et al., 2002). Higher activity and density of sensitive taxonomic groups, such as epigaeic arthropods, can be found in organic systems, as well as higher biomass, and abundance of earthworms and mycorrhizal root length. These measurements indicate higher soil stability, higher aggregation, and higher soil fertility (Mäder et al., 2002).

Although high biodiversity is indicative of ecosystem health, there is no solid evidence that higher diversity increases resistance to perturbation (Sims, 1990). Pesticides in conventional systems influence microbial activities in different ways. In some cases, a predator is removed and a previously controlled prey-species flourishes. In other cases, a pesticide removes nitrifying 
bacteria from the soil, after which nitrification can take several months to recover (Sims, 1990). Some research shows no response of nitrification, or even a positive response to a particular pesticide. In the event that a pollutant removes sensitive species, soil respiration may increase due to digestion by surviving species (Sims, 1990).

Conflicting results require additional investigation in the field of organic agriculture. Mäder et al. (2002) concluded that, because of increased resource use efficiency and greater biodiversity, organic farming systems are a realistic alternative to conventional farming systems.

\section{Management Practices}

\section{Tillage}

Tillage is an important practice for pest, disease and weed management, incorporation of crop residues and nutrients into the soil, and preparation of the seed-bed (Green et al., 2005). Tillage also aids in increasing soil temperature, reducing soil moisture, breaking surface crusts, and creates micro-depressions in the soil surface which are beneficial for infiltration and reducing erosion. Tillage that improves infiltration reduces problems associated with wet soil, and decreases the incidence of seedling diseases (Baldwin, 2006). Burial of weeds or infected crop residues will control some diseases, while other diseases may be transmitted to new crops by farm machinery. When tillage is performed incorrectly, it degrades soil quality.

Tillage may be deleterious to soil when it is performed in excess or at the wrong time because it may break aggregates and reduce macroporosity, creating a compacted layer below the surface (called a plowpan), and increasing decomposition of SOM. These effects leave mineral and nutrient components of the soil increasingly vulnerable to wind and water erosion (White, 2006; Jat et al., 2012). Primary tillage can bring lower quality subsoil to the surface, which promotes development of poor surface conditions. Tillage erosion (Van Oost et al., 2006) has also been identified as a consequence of improper tillage; if done up and down a slope, tillage encourages down-slope erosion and infield variability in texture and yield.

Aggregates are mechanically broken down by tillage, and as a consequence, over time the soil may develop higher bulk density, reduced porosity, higher penetration resistance, and lower infiltration (West \& Post, 2002; Bhattacharyya et al., 2006; Slepetiene et al., 2010). Soil carbon associated with these aggregates also declines under cultivation (Sims, 1990). If soil is tilled to 
the same depth each year, or if tillage is performed when the soil is too wet, a plow-pan may develop a foot or two below the surface of the soil, which roots cannot penetrate.

Wise use of machinery avoids these problems by restricting tillage practices to times when soil is neither too wet nor too dry, by reducing number of passes required to prepare the soil, and by tilling to varying depths. Contour tillage designs plow paths which run perpendicular to the greatest slope within a field, to reduce down-slope erosion.

Two main tillage systems are used: conventional tillage and conservation tillage. Conventional tillage (CT) has been broadly defined as any system that leaves $15-30 \%$ crop residue cover after planting (Duiker, 2006). Conservation tillage systems, such as reduced-till (RT) and no-till (NT), reduce the problems associated with CT by maintaining at least 30\% residue cover on the soil surface (White, 2006). Because RT and NT often disturb the soil to a lesser extent, they tend to preserve crop rotation-induced benefits (Chan et al., 1996) such as greater surface cover, higher macroporosity, higher soil moisture, slower SOM decomposition, higher soil organism populations, and higher levels of surface SOM, humus, and N (Jat et al., 2012; Freixo et al., 2002; Slepetiene et al., 2010; West and Post, 2002). Pore size distribution, pore geometry, and hydraulic properties have all been found to be distinctly improved under NT (Bhattacharyya et al., 2006).

Conversion from CT to NT can sequester $57 \pm 14 \mathrm{~g} \mathrm{C} \mathrm{m}^{-2} \mathrm{yr}^{-1}$ carbon in soil (West \& Post, 2002). These authors found carbon sequestration rates to peak at the 5-10 year mark after conversion to no-till, reaching a new equilibrium after 15 to 20 years. In the same experiment, after enhanced rotational complexity, it took 40-60 years to establish a new carbon equilibrium.

Tillage has been reported to prompt accelerated decomposition of SOM, and as a consequence more $\mathrm{N}$ could be released to be used by plants or microbes, or leached (Sims, 1990). In a case where land is tilled for the first time, a spike in microbial biomass and metabolism may occur, increasing organic matter mineralization; tillage extends this process to greater depths than in untilled soils.

Reduced tillage systems show increased concentrations of aerobes, facultative anaerobes, and nitrifiers at the soil surface (Sims, 1990). In systems which support biodiversity, exudates and hyphae from species, especially of arbuscular mycorrhizal fungi (AMF), benefit aggregate stability. 
Increase in tillage has been related to a decline in SOM, which has detrimental effects on soil structure and biology, and results in a soil's heightened vulnerability to erosion. Erosion and SOM loss can decrease microbial activity. In general, soil degradation is difficult to reverse, and preventative measures such as reduced tillage or careful timing of tillage are required. Time needed to establish a new soil system equilibrium, or for a degraded systems to recover, is highly variable and will depend upon the combination of management strategies (Sims, 1990).

\section{Crop Rotations}

A crop sequence could directly impact soil quality, and is therefore an important factor in an organic agricultural system. Crops are either grown as a monoculture, or as rotations. Major detrimental effects of growing the same crop season after season in the same area include nutrient depletion, soil compaction, and increase in pest and disease problems. Rotations alternate between two or more crops, while complex rotations have additional benefits for soil physical and biochemical properties. A successful rotation combines crops with different growth patterns and requirements, e.g. high and low soil physical protection from wind and water, crops with differing root systems (depth and shape), and crops with variable fertility demands.

An ideal rotation includes a legume component to fix atmospheric nitrogen, crops of different botanical families to break pest and disease life-cycles, and potentially a forage or grass component that could be also used for livestock production. Grazing animals directly on the rotation plots may provide extra benefits such as ensuring a supply of nutrient-rich manure and weed control. Inclusion of a grass component, such as orchardgrass or a grass/legume mixture, adds time and stability for the soil to recover from nutrient removal by crops and the mechanical disturbance of planting and harvesting. Because land-use changes from crops to grass, these rotation cycles may be considered to have transitional components. Grass components will be discussed in greater detail in the next section.

As discussed in previous paragraphs, additions of organic materials such as green manures, cover crops, manure, and compost benefit the microbial community and stabilize soil aggregates. Green manures are crops planted to be later incorporated into the soil while still green, for the benefits of trapping available nutrients, adding organic matter (OM) and erosion control. This practice improves soil structure, stability, and fertility. Green manures may also control weeds and pest life-cycles. Cover crops are grown with the intention of protecting the 
soil, and later killed and left at the soil surface or tilled under. These are often grown in the cold, dry season or during times between cash crops to reduce erosion and improve soil structure.

Management practices used in crop rotations may almost immediately benefit certain soil properties, such as biological nitrogen fixation or erosion control from a cover crop. After conversion from monocropping to multiple cropping systems, many soils require between 5 and 10 years to experience a significant increase in soil quality (West \& Post, 2002). A diverse rotation may take from 15 to 60 years for new carbon sequestration rates to stabilize. Once stabilized, it may be necessary to maintain a minimum cycle of four years of diverse crops (different families), not susceptible to the same pests and diseases, to show a rotation benefit (Baldwin, 2006). In general, a two-year rotation will control foliar diseases, since these are transmitted by contact with infected residues, but some pathogens (such as Streptomyces soil rot, Fusarium wilt, or clubroot) require between 5 and 7 years (Baldwin, 2006).

Related to the rotation composition, leguminous crops within a rotation fix nitrogen, while cover crops capture nitrate to prevent leaching. No-legume component in the rotation leads to less developed soil aggregation (Aoda et al., 1987), while enhanced soil aggregation has been attributed to cover cropping (Sainju et al., 2003; Green et al., 2005). Water retention and hydraulic conductivity are improved by channels made by fine roots of plants such as clover or mustard; these channels could also contribute significantly to water storage and water transport through the soil. Certain rotation compositions, such as soybean-pea rotations, appear to have a more beneficial effect on hydraulic conductivities than other compositions, such as soybeanlentil and soybean-wheat (Bhattacharyya et al., 2006).

Rotations that include cover crops may ameliorate compaction and as a consequence increase crop yields (Duiker, 2006). If the selected rotation component has taproots, these will create channels in the soil and improve infiltration. Crop components also leave different amounts and types of residues behind, which benefit nutrient cycling and stabilize aggregates.

Enhanced rotation complexity sequesters more carbon $\left(20 \pm 12 \mathrm{gCm}^{-2} \mathrm{yr}^{-1}\right)$ in conventionally tilled plots, although not as much as switching to no-tillage production systems (West \& Post, 2002). West and Post (2002) assert that if crop rotation and no-till are used together, short-term enhanced carbon sequestration will be a result of reduced tillage, while longterm enhanced carbon sequestration will be the result of enhanced rotational composition complexity (West \& Post, 2002). 
In addition to rotation components, the length of the rotation (duration) controls the "rotation effect". It is difficult to determine the "best" rotation length, but in general, a long enough rotation will successfully break the reproductive cycle of a pest or weed by depriving species dependent upon a specific crop of their host. A problematic fungus might persist for five years in the soil, and would only be managed by a rotation of at least six years. More persistent pests will require longer rotations or additional measures. Pests may be directly suppressed by microbial dynamics or exudates from a particular crop (NRAES, 2006).

It is well established that rotations are beneficial for an agricultural system. The details of those benefits during transition to and from a grass component will be explored by this research.

\section{Temporary Grass Component in a Rotation}

Grasses included in the rotation introduce a pause in tillage, relief from associated compaction, reduce susceptibility to erosion, and improve SOM (Arshad et al., 2004). Several of the common species used as temporary grasses in a crop rotation are orchardgrass, alfalfa, clover, ryegrass, bromegrass, lucerne, herbs, and festulolium (Acharya et al., 2012). The grass component can be grazed, mowed for residue cover, cut for hay, or turned back into the soil as a green manure.

Some soils improve considerably after 3 or 4 years of grass, while others require 6-10 years (Acharya et al., 2012; Ominski et al., 1999; Entz et al., 1995). Short-cycle rotations are most effective for farmers with a large land area, where periods of intensity are followed by longer-term (6 to 10 years, or more) perennial cover or hay crops (NRAES, 2009).

The dense root systems of grasses incorporate organic matter into the soil, which increases water availability and decreases bulk density (Riley et al., 2008); row crop systems tend to have the opposite effect because of their relatively low proportion of roots to soil, and because the bare pathways between rows are compacted by foot traffic and raindrops (NRAES, 2009). Rotational systems without grass have exhibited higher BD and mean aggregate size, and lower levels of plant available water and aggregate stability due to lower overall levels of SOM (Riley et al., 2008). Perennial grass components are more beneficial to soil structure than no-till cropping systems (Arshad et al., 2004). These plots also tend to be disturbed by mowing or cutting during times in the growing season when soil is drier, which reduces risk of compaction (Wortmann \& Jasa, 2009). 
Perennial grass areas are undisturbed, and therefore share some benefits of NT, such as greater surface cover, higher macroporosity, soil moisture, soil organism populations, higher surface SOM and N, and slower SOM decomposition (Jat et al., 2012; Freixo et al., 2002). An increase in penetration resistance may be observed at the surface of untilled perennial grass systems due to lack of disturbance by tillage (Arshad et al., 2004). As for NT systems, nutrient stratification occurs naturally in the absence of tillage (Reeves, 1994). Under NT conditions, $\mathrm{pH}$ is slightly reduced, while SOM and soluble P and K increase in the top 10cm (Gadermaier et al., 2011). When tillage resumes, nutrients and organic matter are redistributed fairly evenly to the plowed depth.

Older (increased length) grass components exhibit greater root biomass build-up and increased amounts of carbon sequestration compared to shorter grass components. Mixed grassclover component capacity for $\mathrm{C}$ storage has been reported to be between that of cropped land and permanent grassland (Soussana et al., 2004; Drinkwater et al., 1998). Organic grassland yields have been found to meet 70 to $100 \%$ of conventional grassland yields (Mäder et al., 2002).

Grass components in a rotation may reduce but not eliminate weed populations; the effectiveness depends upon leaf area and shading of emerging weeds (Liebman \& Davis, 2000) In these systems, biological activity indicators increase, such as microbial biomass $\mathrm{C}$ (Gadermaier et al., 2011).

Finally, livestock is often combined with temporary grass component in rotational systems to control weeds and deposit organic carbon in the form of manure (Soussana et al., 2004). Grazing accelerates annual shoot turnover, and increases below-ground biomass and fine root productivity (Pucheta et al., 2004; Acharya et al. 2012). Systems without grazing livestock exhibit reduced growth of fibrous roots and lower overall carbon stocks (Reeder \& Schuman, 2002).

\section{Manure and Compost Application}

Manure and composted manure are added to soil to improve biological, chemical and physical soil properties. Additions of these materials have the potential to increase macro- and micro-nutrients, soil water retention, aggregation and aggregate stability, and CEC. If applied in excess or at the wrong time, excess nutrients may run off and cause eutrophication downstream. Wise nutrient management requires minimizing excess and losses by applying amendments 
when the crop is at a growth stage to utilize the nutrients, and then to incorporate the additions with tillage (Liebman \& Davis, 2000).

Organic additions are desirable as long term supplies of fertility (Liebman \& Davis, 2000). The quality of manure or compost (as defined by age, $\mathrm{C}: \mathrm{N}$ ratio, lignin and polyphenol content) is of equal importance as soil temperature, moisture, aeration, $\mathrm{pH}$, tillage, and timing (Liebman \& Davis, 2000).

Some researchers (Klute \& Jacob, 1949; Young et al., 1960; McIntosh and Varney, 1973) have reported no direct benefit of manure on soil physical properties, and attribute improved crop performance to nutrients in the manure (Aoda et al., 1987). Other authors (Arriaga and Lowery, 2003; Bulluck et al., 2002) attribute significant changes in soil structure to manure application. More research is needed to understand the relationship between manure application and soil physical properties.

Manure and composts are rich in stable forms of soil organic matter, which allows SOM to accumulate in the soil. Under continuous manure application, these systems may exhibit higher tolerance to soil degradation by moldboard plowing than systems without consistent manure application (Gadermaier et al., 2011).

Timing of amendment application and other management practices affect the ability of a soil to hold the nutrients, or the ability of a crop to utilize them. Manure incorporated by tillage will decompose more quickly and will be held more tightly by the soil during precipitation events, than would occur if the manure is left on the surface (Green et al., 2005). Excess soil water content paired with low plant demand during winter and spring are associated with greater amounts of leached N. If manure and compost are added on a well-drained soil when plants are able to utilize nutrients, the risk of nutrient erosion will be lower. McIntosh and Varney (1973)'s report found annual applications of $44,000 \mathrm{~kg} / \mathrm{ha}$ of manure to be necessary to maintain SOM during a period of cultivation.

The potential exists for microorganisms or heavy metals contained in the manure to become pollutants in cases where livestock is confined, and manure becomes excessively concentrated (Sims, 1990). Manure application may increase C and N levels in the soil without changing bacterial, fungal, or protozoan populations (Sims, 1990), but it may also be a crucial factor in increasing microbial biomass (Gadermaier et al., 2011). 


\section{Crop Biomass Production}

Biomass is the accumulation, above and belowground, of biological material by the plant. This includes roots, stems, leaves, and reproductive structures. Crop rotations have been found to increase crop biomass production; this may be attributed to an increase in SOC or available inorganic $\mathrm{N}$ in the soil (Smith et al., 2008). It has also been found that inorganic $\mathrm{N}$ is influenced by number of species in a crop rotation, which indicates that species diversity has the potential to improve soil quality (Smith et al., 2008).

For the purposes of this research, aboveground biomass was measured for crops and orchardgrass. Because plant growth is directly linked to soil conditions, biomass is used here as a proxy for soil quality. Yield is the fraction of the biomass usable for economic purposes. In the case of corn, yield was calculated as the dry weight of kernels isolated from the cob, husk, and stalk (Sala \& Austin, 2000). In the case of cowpeas, yield was calculated from dry weight of the entire plant.

Primary productivity is the net amount of carbon assimilated by vegetation in a given period of time (Haberl et al., 2007). Vegetation growth responds to soil conditions (SOM, pore connectivity, bulk density, plant available water, nutrient availability), and therefore primary productivity may be used as a proxy for soil quality. Weather is also an important factor for primary productivity. This is typically factored in using growing-degree-days, or heat units, which are a measure of thermal time used to estimate number of days growth occurs during a given growing season, using daily minimum and maximum temperatures (McMaster \& Wilhelm, 1997)

\section{Objectives and Hypotheses}

The general aim of this study was to observe changes in soil physical properties due to the presence of a temporary grass component in two organic rotation cycles. The 4-yr rotation is defined as a four year crop cycle, and the 7-yr rotation is defined by the same four years of cropping followed by three years of orchardgrass (Dactylis glomerata). The specific objectives that guided this study were as follows:

Objective 1: Measure differences in soil properties and plant biomass between and within first and last crop components of two rotation cycles subjected to two levels of composted manure input. 
i. - Compare soil properties and biomass obtained in the 4-yr rotation corn to the 7-yr rotation corn, and compare 4-yr rotation kale to 7-yr rotation kale, both at two levels of compost input (Figure 1a).

ii. - Measure soil properties and biomass in the corn plots (first crop component) and kale (last crop component) subjected to two levels of manure application. In the 4-yr rotation, the crop components follow other crop components; in the 7-yr rotation, corn follows three years of temporary orchardgrass, and kale follows previous crops (Figure 1b).

\section{Objective 2: Determine changes in soil physical properties in the transition from} crops to grass components and from grass to crops in the 7-yr rotation, subjected to two levels of composted manure input.

i.- Measure and compare soil properties in the last crop component and first year of orchardgrass (kale and O5), and the last year of orchardgrass with the first year crop component (O7 to corn) (Figure 2).

The general hypotheses that drive this study are as follows:

In an organic crop rotation, changes in soil physical properties (soil quality) after three years of grass persist between the first (corn) and last year (kale/cowpea) crop components and will affect crop performance. An improvement will be considered a decrease in BD, and an increase in the following: DA-GMD, WA-GMD, SOM, pH, STP, STK, STCa, STMg, STZn, TotN, corn biomass, and cowpea biomass.

Soil physical properties (physical health) improve with the inclusion of a three year grass component into the organic rotation, and the improvement is measurable at the end of the third year of grass.

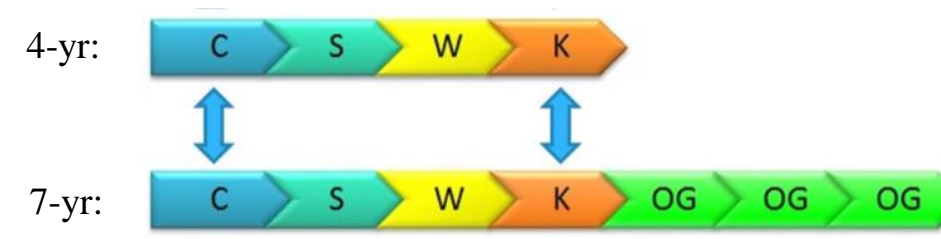

Figure 1a. Comparison of like-crop components between rotations to determine effect of temporary grass component and manure application. 


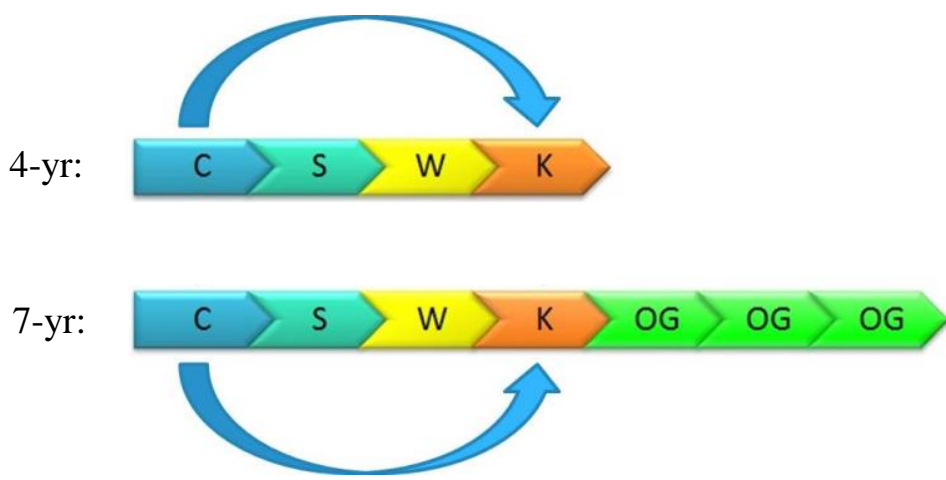

Figure 1b. Comparison of first (corn) and last (kale) crop component within each rotation to determine the effect of crop and manure application.

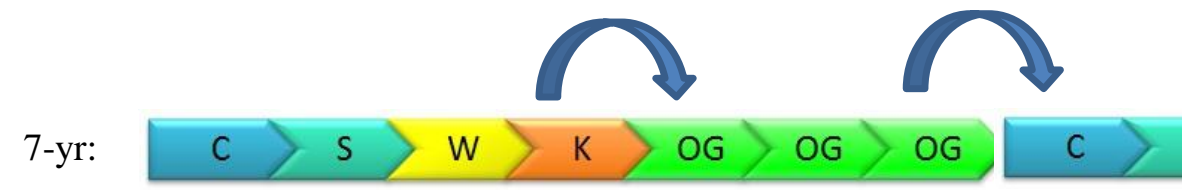

Figure 2. Transition from cropping cycle $(\mathrm{K}=$ kale) into orchardgrass component $(\mathrm{OG})$, and then from OG to cropping cycle $(\mathrm{C}=$ corn $)$.

\section{MATERIALS AND METHODS}

\section{Site Description}

The study was conducted at the West Virginia University Certified Organic Farm $\left(39.647502^{\circ} \mathrm{N}, 79.93691^{\circ} \mathrm{W}\right)$ in Morgantown, WV, USA. The weather conditions are transitional between a humid subtropical and humid continental climate, with mean air temperature in January of $-0.27^{\circ} \mathrm{C}$, mean air temperature in July of $23^{\circ} \mathrm{C}$, and mean annual precipitation of $1063 \mathrm{~mm}$. Weather data for years under study $(2012,2013$, and 2014) can be found in the Results and Discussion section in Table 2. The elevation in this area is between 243.8-475.2m (NOAA, 2006).

Soils in the study area are classified as Culleoka-Westmoreland (CwE), Dormont and Guernsey (DgB, DgC, DgD), or Tilsit (TlB) silt loams (Table 1). Figure 3 presents the spatial layout of the experimental plots and the soil map units. All soils in the area are silt loams between 3-25\% slope, 1.0-5.0\% SOM, and 1.20-1.60 Mg/m $3{ }^{3} \mathrm{BD}$, with an average $\mathrm{pH}$ of 5.4 (Web Soil Survey, 2012). More detailed soil property information may be found in Appendix A, Table A1. 
Table 1. Taxonomic Classification of Soil Series in Experimental Area

\begin{tabular}{|l|l|}
\hline Soil Series & Taxonomic Classification \\
\hline Culleoka-Westmoreland (CwE) & Fine-loamy, mixed, active, mesic Ultic Hapludalfs \\
\hline Dormont and Guernsey (DgB, DgC, DgD) & Fine-loamy, mixed, superactive, mesic Oxyaquic Hapludalfs \\
\hline Tilsit (TlB) & Fine-silty, mixed, semiactive, mesic Typic Fragiudults \\
\hline
\end{tabular}

\section{Rotation Experiments Description}

An existing crop rotation experiment that included two cycles was used to fulfill the objectives of this study. The two rotation cycles were established in the year 2000, and will be referred to in this document as the 4-yr rotation and the 7-yr rotation. Maps and cycleillustrations of the rotations may be found in Appendix A, Table A2a and A2b. The 4-yr rotation consisted of continuous four year duration crop rotation, and the 7-yr rotation consisted of seven year duration rotation, four crops followed by three years of orchardgrass. Related to the rotation composition, in both rotations, corn (Zea mays L.) was followed by soybeans (Glycine max L.), which were followed by wheat (Triticum aestivum L.). The last established crops in the rotation, were a combination of kale (Brassica oleracea L.) and cowpeas (Vigna unguiculata L.). Kale was fall-seeded as a cover crop, and harvested in early summer, followed in the same year by cowpeas which covered these plots for the summer. After the kale/cowpea crop, the plots assigned to the 4-yr rotation were seeded to rye (Secale cereale) and vetches (Vicia villosa L.) as a winter cover crop until the corn, the first crop in the rotation, was planted the following spring. Following the summer cowpeas, the plots assigned to the 7-yr rotation were seeded to an orchardgrass (Dactylis glomerata L.) and red clover (Trifolium pratense L.) mixture and left untilled for three years. In summary, the 4-yr rotation consisted of a four year duration crop rotation corn (C), soybean $(\mathrm{S})$, wheat $(\mathrm{W})$, kale/cowpea $(\mathrm{K})$, and the 7-yr rotation consisted of a seven year duration rotation, four crops (CSWK) followed by three years of orchardgrass. In Appendix A, Table A3, please find varieties of all crops planted, including relative percentages of the orchardgrass-red clover mixture.

An additional organic input treatment was imposed on the 4-yr and 7-yr rotations. Dry composted manure was spread just before seeding in May on corn plots, and in September on wheat plots, onto Manured plots (M) at the amount of $22.5 \mathrm{Mg} / \mathrm{ha}$, or $68 \mathrm{~kg}$ total $\mathrm{N}$. Unmanured plots $(\mathrm{U})$ received no manure. Soybean, kale, and orchardgrass rotation components received no 


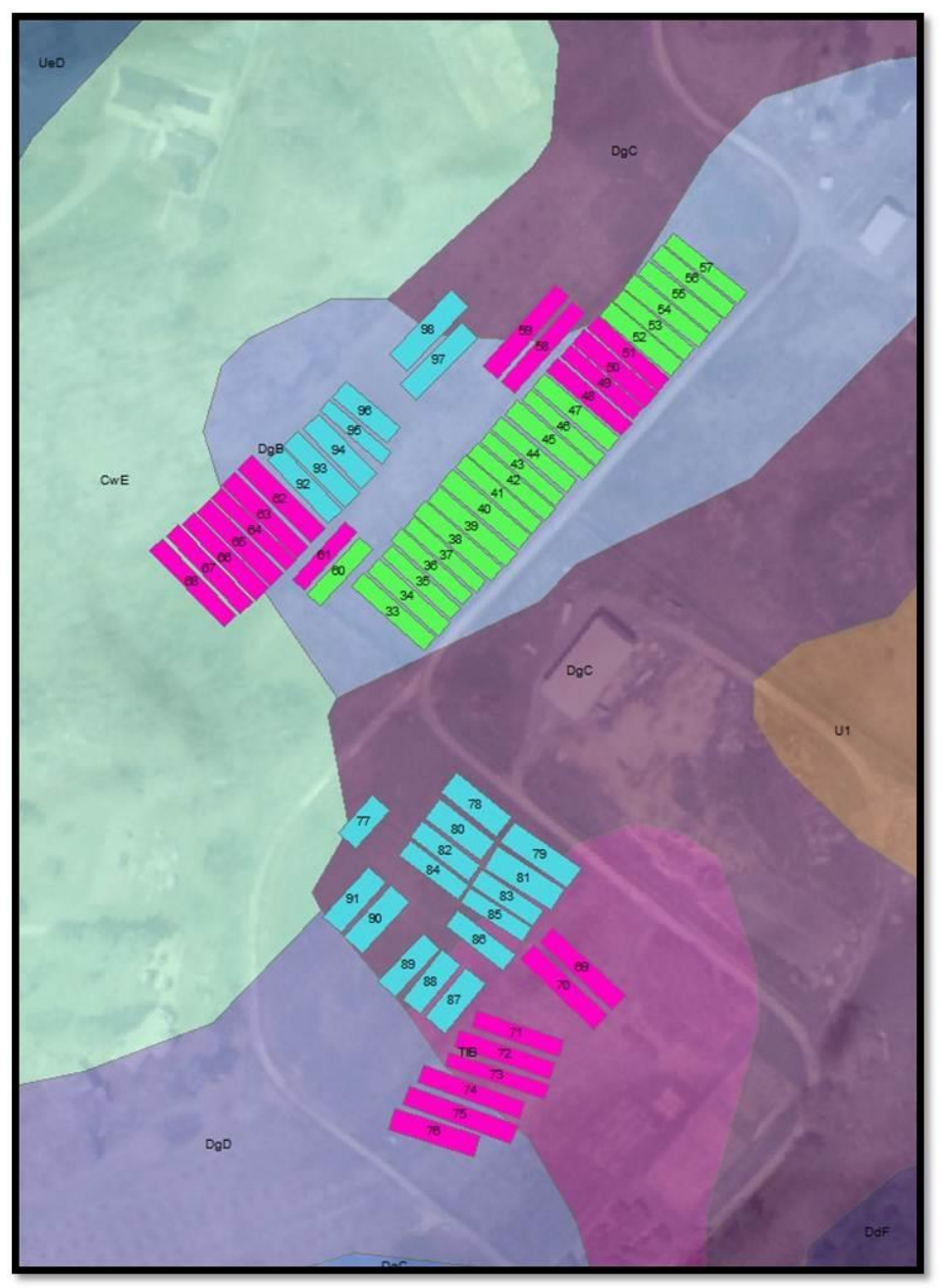

Figure 3. Spatial distribution of the soil map units and rotation study plots are separated by blocks. Soil series are presented in different colors: $\mathrm{CwE}$ (light green), $\mathrm{DgB}$ (light blue), $\mathrm{DgC}$ (mauve), DgD (periwinkle), and TlB (pink). Plots within Block 1 are shown in lime green, Block 2 in blue, and Block 3 in magenta.

manure. Manure composition was determined each year, and in 2011 contained $31.9 \mathrm{~kg} / \mathrm{ton} \mathrm{N}$, $7.0 \mathrm{~kg} /$ ton $\mathrm{P}$, and $28.2 \mathrm{~kg} /$ ton K. Values for manure added in 2012, 2013, and 2014 are available, but in Appendix A, Table A4, laboratory analysis information is available for manure composition added from 2008-2011. These data are not available for the two years soil samples were taken, but the available data provide the compositional range of this material.

The agronomic management for the rotations is described in the following paragraph. Manured plots were manured with a manure spreader, rototilled, and disked to a depth of $10 \mathrm{~cm}$, and seeded the following day to corn, wheat or rye-vetch. Wheat, orchardgrass/red clover, and kale were fall-seeded, while a rye-vetch cover crop was seeded into the corn plots. In the spring, 
the cover crops (green manure) were disked into the soil, and corn plots were planted. Kale plots, planted in fall and harvested in the spring, were seeded in spring with cowpeas as a summer cover crop, and in fall they would be grazed, and then would either be planted to orchardgrass (7-yr rotation) or rye-vetch before corn (4-yr rotation). They were seeded with a Tye No-Till Manual Seeder at a rate of $54.9 \mathrm{Mg} / \mathrm{ha}$. This was the general seeding rate for the experiment design, however differences existed between years depending on possible changes in tractor setting, crop variety or germination. For example, the planting and row distances for corn in 2013 were $0.75 \mathrm{~m}$ and $1.0 \mathrm{~m}$, respectively. This variability should be taken into account when considering biomass data for both 2013 and 2014.

Grass plots in the 7-yr rotation were grazed by sheep at least once but no more than twice during the year (Fig. 4) at stocking rates between 5.7 and 6.6 ewes and their lambs/ha for no more than one or two days at a time. Cowpea plots were also grazed in September to remove aboveground biomass. No crops in the 4-yr plots were ever grazed. Except for sheep in grass and cowpea plots, no plots were weeded, manually or otherwise.

The experimental plots were divided into three blocks following previous land-use and three soil types found within the research area, as shown by Figure 1. Before the rotation experiment was established in 2000, Block 2 had been cultivated as an apple orchard, and Blocks 1 and 3 were permanent grassland. Crop component and rotation within each block was randomly assigned; each crop component was represented evenly in each block. Rotation plots in Blocks 1 and 3 measured $167 \mathrm{~m}^{2}$, and plots in Block 2 measured $116 \mathrm{~m}^{2}$. The previously described experimental design resulted in 24 plots assigned to the 4 -yr rotation, and 42 plots assigned to the $7-y$ rotation. 


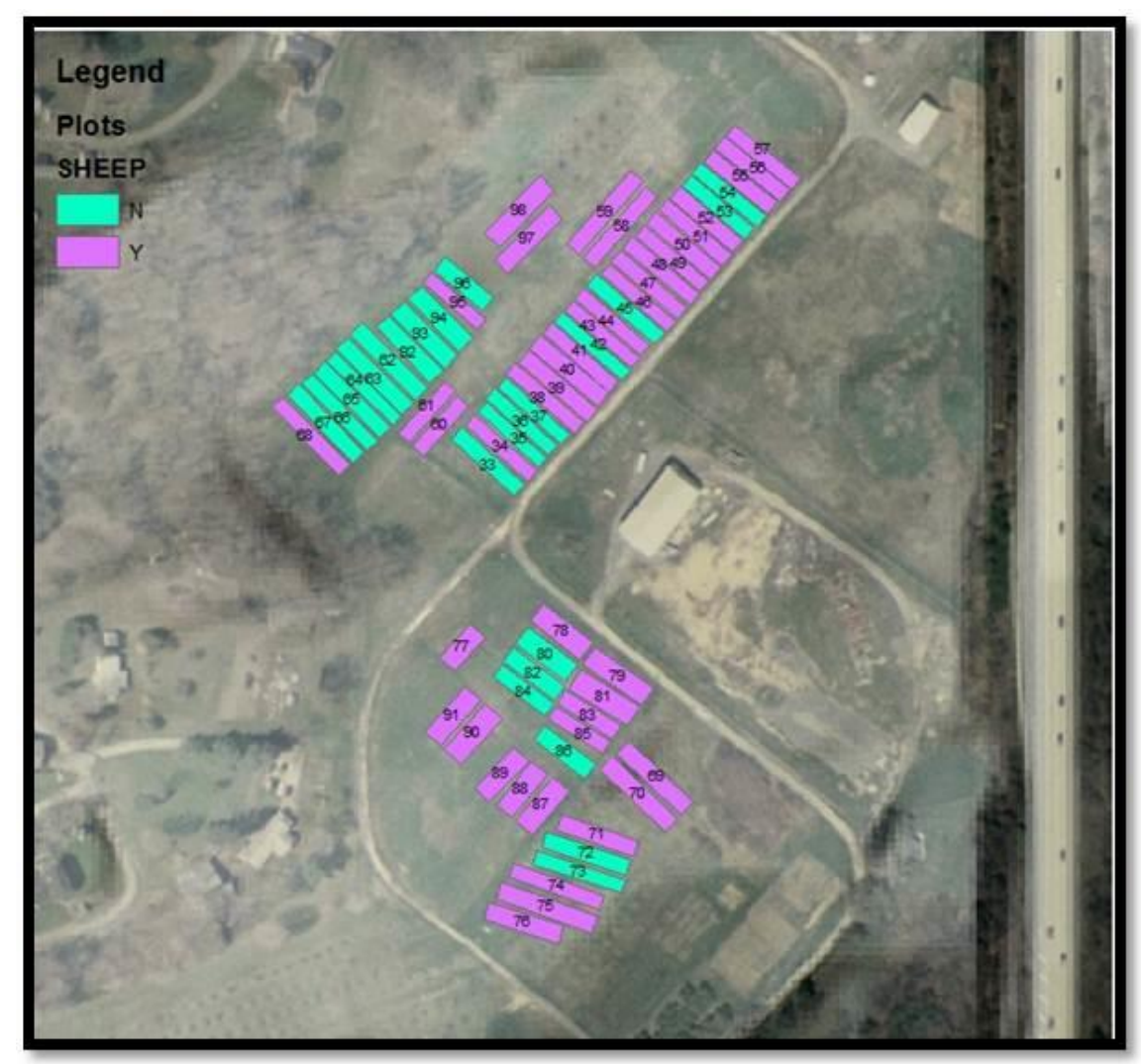

Figure 4. Plots in the 4-yr rotation are shown in green. Plots in the 7-yr rotation are shown in purple.

Using the previously established crop organic rotation, two experiments were designed to test the study's hypotheses and fulfill objectives cited in previous sections.

\section{Experiment I}

Experiment I was designed to address Objective 1: " to measure differences in soil physical properties and biomass between first and last crop components of two rotation cycles subjected to two levels of composted manure input" (sub-objectives i, ii). Measurements were made in the 4-yr rotation and the 7-yr rotation to evaluate soil physical properties and biomass (compare like-crop components and manured to unmanured plots). The hypothesis was that three years of grass in the 7-yr rotation will significantly improve soil physical properties in experimental plots: this improvement would be indicated by a decrease in BD, an increase in DA and WA-GMD, an increase in SOM and plant available nutrients, and an increase in biomass. For this experiment, properties measured included surface bulk density $(0-5 \mathrm{~cm})$, aggregate 
stability $(0-5 \mathrm{~cm}), 0-10 \mathrm{~cm}$ soil organic matter $(\mathrm{SOM}), 0-10 \mathrm{~cm}$ bioavailable nutrients, $0-10 \mathrm{~cm} \mathrm{pH}$, and crop biomass.

The experiment was designed as a randomized complete block design with three factors. The three factors studied were rotation (two levels: "7-yr = with", and " $4-\mathrm{yr}=$ without" grass component), composted manure level (two levels: manured and un-manured), and crop component (two levels: first (corn) and last (kale) year crop component) with three blocks/reps. Experimental data were analyzed using analysis of variance (ANOVA). Analysis of variance (ANOVA) was performed with PROC GLM procedure in SAS 9.2 (SAS Institute Inc., 2009). Means separation among treatments was determined by least significant difference (LSD). Although an alpha $(\alpha)$ level of 0.05 is traditional, 0.1 was used for this experiment; this $\alpha$ was selected because it is increasingly used in agricultural sciences as the standard for field sampling experiments (Stoddard et al., 1998).

\section{Experiment II}

Experiment II was designed to address Objective 2, "to determine changes in soil physical properties and biomass in the transition from crops to grass component, and from grass to crops in the 7-yr rotation, subjected to two levels of composted manure input" (sub-objectives i, ii). This experiment was performed specifically on the 7-yr rotation (with grass component). The hypothesis tested was that soil physical properties improved within the 7 -yr rotation due to and after the grass component was introduced into the rotation. The hypothesis was that soil quality would improve due to the transition from the crops to the grass component, and that this effect would be reversed during the transition from the grass component into the first year of the cropping cycle. An improvement in soil quality would be indicated by a decrease in BD, an increase in DA and WA-GMD, an increase in SOM and plant available nutrients, and an increase in biomass.

The approach used to test the hypothesis was to measure soil properties in the last crop component of the rotation (kale/cowpea plots) and compare them to year 1 of the grass component, and then to perform a separate comparison of year 3 of orchardgrass to the first crop component (corn).

Properties measured were the same as measured in Experiment 1: surface bulk density (0$5 \mathrm{~cm})$, aggregate stability $(0-5 \mathrm{~cm}), 0-10 \mathrm{~cm}$ soil organic matter (SOM), $0-10 \mathrm{~cm}$ bioavailable nutrients, $\mathrm{pH}$, and biomass. 
The experiment was designed as a randomized complete block design with two factors. The tests performed compared two factors: crops (last year of grass vs first crop of the rotation/corn, and last crop of the rotation/kale vs first year of grass) and composted manure level (two levels: manured and unmanured), with three blocks/reps. Experimental data were analyzed using analysis of variance (ANOVA). Analysis of variance (ANOVAs) was performed with PROC GLM procedure in SAS 9.2 (SAS Institute Inc., 2009). Means separation among treatments was determined by least significant difference (LSD). Although an alpha ( $\alpha$ ) level of 0.05 is traditional, 0.1 was used for this experiment; this $\alpha$ was selected because it is increasingly used in agricultural sciences as the standard for field sampling experiments (Stoddard et al., 1998).

\section{Data Collection and Analysis}

\section{Soil Sampling}

Data collection was performed between April and October 2013/2014. Soil quality indicators were sampled between April and May of both 2013 and 2014. Soil quality indicator variables measured were surface bulk density $(0-5 \mathrm{~cm})$, aggregate stability $(0-5 \mathrm{~cm}), 0-10 \mathrm{~cm}$ stratified bioavailable nutrients and SOM (0-10cm depth), $\mathrm{pH}$, and biomass.

Soil sampling was performed following a standard sampling strategy between years: five sampling points were randomly selected in each plot with the objective of acquiring a representative sample of the whole plot surface. The following soil samples were taken at each selected plot sampling point: a) two intact cores were sampled, one for surface bulk density (0$5 \mathrm{~cm}$ ) (Uhland, 1949); b) one intact soil core was obtained for surface aggregate stability wet and dry (0-5cm) (Yoder, 1936; Diaz-Zorita, et al., 2002); c) composite soil sample composed of five $0-10 \mathrm{~cm}$ soil cores per point were taken with an oakfield sampler, and cut in segments (0-5 and 510), the combined stratified pieces were dried, ground, sieved to a size of $<2 \mathrm{~mm}$, and analyzed for bioavailable nutrients (total N, P, K, Ca, Mg, Zn), pH and SOM.

\section{Soil Sample Processing: Methodology and Analysis}

Soil Bulk Density: Intact soil cores for soil bulk density were taken in the field with the Uhland sampler (Uhland, 1949) at a depth of 0-5 cm, and transported to the laboratory. Soil 
cores were weighed at field moisture. The intact soil cores were oven-dried, and re-weighed to calculate dry bulk density, using Equation 1:

$$
\rho=\text { Soil dry weight }(\mathrm{g}) / \text { cylinder volume }\left(\mathrm{cm}^{3}\right) \quad \text { Eq } 1 .
$$

Aggregate Stability: Aggregate stability was measured using a second intact core sampled with the Uhland sampler (Uhland, 1949). Samples were gathered at the same time under the same field conditions. After being weighed in an aluminum plate, the sample was placed in a brown paper bag and allowed to dry at room-temperature $\left(21.1^{\circ} \mathrm{C}\right)$ for approximately $48 \mathrm{hrs}$. Equations used to calculate mean weight diameter (MWD) and geometric mean diameter (GMD) are provided below (Eq. $2 \& 3$ ).

a) Dry aggregate stability: The sample was broken by the drop-shatter method (DiazZorita et al., 2002), shaken in a Fritsch Analysette 3 shaker for 30 seconds at an amplitude of $2 \mathrm{~mm}$. Soil was shaken through six nested sieves of the following sizes: $16 \mathrm{~mm}, 8 \mathrm{~mm}, 4 \mathrm{~mm}, 2 \mathrm{~mm}, 1 \mathrm{~mm}$, and 500 microns.

b) Wet aggregate stability: The $4-8 \mathrm{~mm}$ size fraction obtained from the aggregate stability processing was weighed, and separated for wet-sieving by the Yoder method (Yoder, 1936) at approximately 18 oscillations per minute, with a submergence time of approximately 2 seconds for a total of five minutes.

$$
M W D=\sum_{i=1}^{n} \bar{x} l w i \quad \text { Eq. } 2
$$

where $\bar{x}=$ the mean diameter of each size fraction and $w i=$ the proportion of the total sample weight occurring in the size fraction " $i$ ".

$$
G M D=\exp \left[\sum_{i=1}^{n} w i \log \overline{(x l)} / \sum_{i=1}^{n} w i\right] \quad \text { Eq. } 3
$$

Geometric Mean Diameter (GMD) and Mean Weight Diameter (MWD) are aggregate stability indices calculated from collected and processed field samples. GMD was the index selected to be discussed for the results of this study. Geometric Mean Diameter was selected because of its higher sensitivity to the ANOVA analysis performed, and its accurate representation the experimental data. Mean Weight Diameter (MWD) values for results can be found in Appendix B of this document.

Bioavailable nutrients, $\mathrm{pH}$ and soil organic matter (SOM): After obtaining the stratified samples in the field, the composite samples were oven-dried at $105^{\circ} \mathrm{C}$ for $24 \mathrm{~h}$, ground, and 
sieved. Soil organic matter and total nitrogen were determined with the dry combustion methodLECO (Nelson and Sommers, 1996; LECO, 2003). Bioavailable nutrients (P, K, Ca, Mg, and Zn) were extracted with Mehlich 3 extraction (Mehlich, 1984). Soil pH was measured in a 1:1 soil water solution (Kalra, 1995).

\section{Biomass Sampling, Methodology, and Analysis}

Aboveground crop biomass was sampled between August and October 2013 and 2014 at harvest time (full maturity). Biomass sampling method was specific for each crop. Biomass sampling method was selected based on the crop to be sampled: corn, cowpea, or orchardgrass.

Corn biomass was sampled in late October 2013 and 2014. Plots were planted to six corn rows, with an average distance of $0.75 \mathrm{~m}$ between rows in 2013, and $1 \mathrm{~m}$ in 2014 . For the corn component biomass sampling, the border effect was accounted for by not sampling $1.5 \mathrm{~m}$ at the beginning, and 1.5 the end of each row, and by eliminating two perimeter/external rows on each side. Ten meters of the two center rows were selected for biomass sampling. For these rows, a total plant count was taken (plant density estimation), and from each third of the $10 \mathrm{~m}$ row, two whole plants including ears, were harvested (a total of 6 plants per plot). To calculate biomass per unit area, planting density per unit area was estimated from the area occupied by individual plants (distance within and between rows). Weeds were also harvested in 2014 to account for total biomass produced per unit area. The six corn plants per plot were dried at $\sim 60^{\circ} \mathrm{C}$ for $72 \mathrm{hrs}$. The ears were separated from the stalks and leaves, and weighed separately. The corn kernels were separated from the cob. The kernels were weighed and reported as grain yield, while the cob biomass was added to the stalk and leaf biomass (Eck, 1986).

Cowpea biomass was harvested in September 2013 and 2014. Soil properties were gathered in kale plots, but because biomass was sampled later in the summer, kale biomass was not available. Cowpea is the cover crop following kale, and was harvested to represent growing conditions at the end of the crop component of the rotations. Cowpea rows were planted with an average row distance of $0.75 \mathrm{~m}$. Biomass was measured eliminating boarder effects, as explained in the previous paragraph. Three random samples were collected per plot using a $0.068 \mathrm{~m}^{2}$ quadrat; each sample represented two randomly selected cowpea plants. In the selected harvesting areas, total above ground biomass was determined by cutting and separating cowpea plants from weeds. Cowpeas and weeds were dried and weighed separately (Sala \& Austin, 2000). 
Orchardgrass plots were planted by broadcasting the seed in the fall, and left in the field for three full years. Orchardgrass biomass was estimated using the falling plate meter technique (Rayburn \&Rayburn, 1998). Height on the measuring-stick of the falling plate was given in $\mathrm{cm}$ (Harmoney et al., 1997). Heights were taken at twenty locations along a transect down the center of each grass plot, and heights were averaged to estimate mean height for each plot. These measurements were made before and after two annual grazing events (in July and October). In 2013, for two of the twenty locations per plot were randomly selected and aboveground biomass was harvested using a $0.068 \mathrm{~m}^{2}$ rectangular quadrat. Using the grass height and biomass measurements, a regression calibration curve relating height to biomass was built (Appendix A, Figure A1.) The experimentally obtained height-biomass calibration (Equation 6) was used to estimate the biomass for 20 randomly selected points per plot:

Estimated Biomass $\left(\mathrm{kg} \mathrm{ha}^{-1}\right)=193.29 *[$ Measured Height in $\mathrm{cm}]-39.57$ Eq.6

\section{RESULTS}

\section{Weather Description}

Precipitation and temperature data for 2012, $2013 \& 2014$ are provided below, in Table 2.

Table 2. Summary of temperature, precipitation and growing degree days (GDD) for 2012- 2014.

\begin{tabular}{lccc}
\hline \hline & \multicolumn{3}{c}{ Year } \\
\cline { 2 - 4 } Variables & 2012 & 2013 & 2014 \\
& & & (until 10/23/14) \\
Total Annual Precipitation $(\mathrm{mm})$ & 898.4 & 1045.5 & 932.9 \\
Average Annual Temperature $\left({ }^{\circ} \mathrm{C}\right)$ & 13.3 & 11.9 & 12.9 \\
Annual Maximum Temperature $\left({ }^{\circ} \mathrm{C}\right)$ & 19.0 & 17.0 & 18.7 \\
Annual Minimum Temperature $\left({ }^{\circ} \mathrm{C}\right)$ & 7.5 & 6.9 & 7.2 \\
Total GGD & 2095.0 & 1950.8 & 1893.1 \\
Total Precipitation Corn Growing Season $(\mathrm{mm})$ & 401.6 & 609.6 & 591.8 \\
Corn GGD & 1809.4 & 1679.2 & 1738.6 \\
\hline \hline
\end{tabular}

\section{General Description}

Soil and biomass variables were taken for two years: 2013 and 2014. Considering changes in weather conditions between 2013 and 2014, the associated effects on tillage quality 
(affecting macro-aggregation) and biomass production, and slight management differences discussed in the Discussion section, data from 2013 and 2014 were analyzed separately.

Overall 2013 means for physical, chemical, and biomass variables measured for the experimental plots included in Experiments 1 and 2 are provided in Appendix B, Table B1a and b. These values are for all three soil series, management histories (for which the blocks were used) included in the experiment, and all treatments (manured, unmanured, 4-yr rotation, 7-yr rotation). These values are generally within the normal range of values for silt-loam agricultural soils (Appendix A, Table A1).

All Overall Mean values in the following paragraph are for the year 2013. Overall Bulk Density (BD) values ranged from 0.91 to $1.48 \mathrm{Mg} / \mathrm{m}^{3}$. Soil Organic Matter (SOM) values ranged from $2.3 \%$ to $7.6 \%$. Overall GMD dry aggregate stability (DA-GMD) values ranged from 1.3 to $11.2 \mathrm{~mm}$. Wet GMD aggregate stability (WA-GMD) values ranged from 0.7 to $6.2 \mathrm{~mm}$.

Overall phosphorus $(\mathrm{P})$ values ranged from 2.0 to $218.5 \mathrm{mg} / \mathrm{kg}$. Potassium $(\mathrm{K})$ values ranged from 37.0 to $368.5 \mathrm{mg} / \mathrm{kg}$. Soil $\mathrm{pH}$ values ranged from 3.4 to 6.8 . Overall calcium $(\mathrm{Ca})$ values ranged from 176.0 to $4670.0 \mathrm{mg} / \mathrm{kg}$. Overall magnesium $(\mathrm{Mg})$ values ranged from 45.0 to $336.0 \mathrm{mg} / \mathrm{kg}$. Zinc ( $\mathrm{Zn})$ values ranged from 0.5 to $24.7 \mathrm{mg} / \mathrm{kg}$. Soil Organic Matter (OM) values ranged from 1.1 to $8.4 \%$. Total nitrogen $(\mathrm{N})$ values ranged from 0.6 to $4.3 \mathrm{~g} / \mathrm{kg}$.

2013 cowpea biomass (measured as the summer cover crop following the kale crop component) ranged from $1.5-3.2 \mathrm{Mg} / \mathrm{ha}$. For 2013, corn biomass values are not provided due to problems with corn stand and germination.

Overall 2014 means for physical, chemical, and biomass variables measured for the experimental plots included in Experiments 1 and 2 are also generally within the normal range of values for silt-loam agricultural soils (Appendix A, Table A1).

All values in the following paragraph are for the year 2014. Overall Bulk Density (BD) values ranged from 0.97 to $1.42 \mathrm{Mg} / \mathrm{m}^{3}$. Soil Organic Matter (SOM) values ranged from $1.1 \%$ to $8.7 \%$. Overall GMD dry aggregate stability (DA-GMD) values ranged from 1.5 to $3.0 \mathrm{~mm}$. Wet GMD aggregate stability (WA-GMD) values ranged from 1.1 to $5.8 \mathrm{~mm}$.

Overall phosphorus $(\mathrm{P})$ values ranged from 1.0 to $246.0 \mathrm{mg} / \mathrm{kg}$. Potassium $(\mathrm{K})$ values ranged from 29.0 to $462.0 \mathrm{mg} / \mathrm{kg}$. $\mathrm{pH}$ values ranged from 5.5 to 7.7 . Overall calcium (Ca) values ranged from 640 to $4680 \mathrm{mg} / \mathrm{kg}$. Overall magnesium $(\mathrm{Mg})$ values ranged from 37.0 to 
$311.0 \mathrm{mg} / \mathrm{kg}$. Zinc $(\mathrm{Zn})$ values ranged from 0.6 to $31.8 \mathrm{mg} / \mathrm{kg}$. Total nitrogen $(\mathrm{N})$ values ranged from 0.7 to $4.4 \mathrm{~g} / \mathrm{kg}$.

Corn biomass values will not be discussed on an "area" basis, but in a "plant by plant" basis. Uncontrollable management issues created uncorrectable mistakes in estimating biomass on an area basis, although treatment means may be compared without significance. Overall stalk biomass by plant averaged 176.1g \pm 35.3. Mean ear mass was $152.8 \mathrm{~g} \pm 51.0$. Mean kernel mass by plant was $115.8 \mathrm{~g} \pm 36.0$. Total biomass per plant (stalks, cobs, and kernels) was $315.7 \mathrm{~g} \pm$ 69.9. 2014 cowpea biomass was measured on a per-plant basis as total biomass (stalks, leaves, ears, and kernels), and ranged from 253g-436g. 2014 cowpea biomass ranged from 1.7-2.3 $\mathrm{Mg} / \mathrm{ha}$.

\section{EXPERIMENT I:}

\section{Within-Rotation Effect of Manure and Crop on Physical and Chemical Quality}

In the next section, the effect of manure and crop within rotation on 2013 soil physical property values [bulk density (BD), dry geometric mean diameter aggregation (DA-GMD), wet geometric mean diameter aggregation (WA-GMD), and soil organic matter at $0-10 \mathrm{~cm}$ depth (SOM)] will be discussed (Table 3).

Stratified bioavailable nutrients discussed, for the depths $0-5$ and $5-10 \mathrm{~cm}$, are $\mathrm{pH}$, soil organic matter (SOM), soil test phosphorus (STP), soils test potassium (STK), soil test calcium (STCa), soil test magnesium (STMg), soil test zinc (STZn), and total nitrogen (TotN) (Tables 5, 6,7 , and 8).

\section{Manure effect within rotation type (4-yr and 7-yr)}

In 2013, surface bulk density (BD) values were statistically significantly affected by composted manure addition regardless of rotation. In both rotations, plots receiving composted manure exhibited significantly lower bulk density than plots receiving no composted manure (Table 3). Within rotation, dry aggregate stability (DA-GMD) and wet aggregate stability (WAGMD) showed the same behavior: values were significantly larger in crops planted in the 4-yr rotational cycle not receiving composted manure, as shown below in Table 3. No significant 
difference was observed between manured and unmanured plots in the 7-yr cycle. In 2013, SOM values (average from $0-10 \mathrm{~cm}$ ) were significantly affected by composted manure addition in both the 4-yr and the 7-yr rotation cycle (Table 3). In both rotations, plots receiving composted manure exhibited significantly higher SOM than plots receiving no composted manure.

In the 4-yr rotation cycle soil $\mathrm{pH}$ values were significantly affected by composted manure addition at all depths (Table 4). In all cases, soil $\mathrm{pH}$ was higher in manured plots than in unmanured plots. The same was found to be true for stratified soil organic matter (SOM). In this study it was observed that regardless of rotation cycle or crop, there was a significant effect of manure application on the 0-10 cm bioavailable $\mathrm{P}, \mathrm{K}, \mathrm{Ca}, \mathrm{Mg}, \mathrm{Zn}$, and total nitrogen (Tables 712). In all cases where a significant difference was found, nutrients were higher in manured plots than in unmanured plots.

\section{Crop effect within rotation type (4-yr and 7-yr)}

In 2013, no significant effect of crop was observed on bulk density in either rotational cycle. Dry and wet aggregate stability showed the same behavior: values were significantly higher in corn plots than in kale plots, but this difference was only significant in 7-yr plots. No significant effect of crop was found on DA-GMD or WA-GMD in 4-yr plots (Table 3). The main effect of crop on SOM within rotation was statistically significant regardless of rotation cycle. In both the 4-yr and 7-yr plots, corn plot SOM was significantly higher than that of kale plots.

A significant effect of crop was only found on $\mathrm{pH}$ at the surface $(0-5 \mathrm{~cm})$ in the 7 -yr corn plots; the measured pH was higher in the corn plots than in the kale plots. Regardless of rotation, corn plots show a higher stratified SOM content than kale plots. Within the 4-yr and 7-yr rotations, all nutrients responded positively to manure application. Within rotation, the effect of crop is significant on many nutrients; values in corn plots are significantly higher than those in kale plots (Table 7). Regardless of rotation, corn plots exhibited statistically significant higher STZn and TotN than kale (Table 7). 


\section{Interactions within rotation type (4-yr and 7-yr) between manure and crop}

There is a highly significant interaction between manure and crop on bulk density values in the 4-yr rotation: the effect of manure on corn was higher than on kale. No interaction was present for BD values in the 7-yr rotation. A significant interaction between manure and crop was also found for DA-GMD values. The interaction was observed in 7-yr plots, but not in 4-yr plots. No interaction was found between manure and crop for wet aggregate stability.

For $\mathrm{pH}$, an interaction was observed between manure and crop in $4-\mathrm{yr}$ plots at the $0-10 \mathrm{~cm}$ depth, but not in the 7-yr plots. For stratified SOM, an interaction was observed between manure and crop in 4-yr plots, but not in 7-yr plots. Soil test P (STP) and soil test K (STK) between 0$10 \mathrm{~cm}$ showed an interaction between manure application and crop studied (corn or kale) for the 4-yr rotation; however no interaction was observed for the 7-yr rotation (Table 6). For soil test calcium (STCa), an interaction between manure application and crop was found for the 4-yr rotation; however the interaction was only observed for the $7-y$ r rotation at the $5-10 \mathrm{~cm}$ depth (Table 6). The 4-yr rotation shows a high-magnitude interaction effect of crop and manure on measured zinc (STZn) and nitrogen (TotN); at all depths unmanured corn and kale plots had a similar TotN and STZn, but significant differences were observed when the corn and kale plots were manured. No interactions were observed for the 7-yr rotation, regardless of crop. 
Table 3: Within-rotations (4-yr and 7-yr) main effects of manure and crop on 2013 soil physical quality indicators

\section{Rotation 4-yr Rotation 7-yr}

2013 Variables

$\mathrm{BD}$
$\mathrm{Mg} / \mathrm{m}^{3}$

DA-GMD

WA-GMD

SOM

BD

DA-GMD

WA-GMD

$\mathrm{mm}$

SOM

Manure

$\begin{array}{ll}\text { M } & 1.09^{\mathrm{b}} \pm 0.68 \\ \mathrm{U} & 1.22^{\mathrm{a}} \pm 0.93\end{array}$

$3.6^{\mathrm{b}} \pm 1.5 \quad 3.7^{\mathrm{a}} \pm 0.8$

$3.9^{\mathrm{a}} \pm 1.3$

$4.6^{\mathrm{a}} \pm 1.6 \quad 2.6^{\mathrm{b}} \pm 1.2$

$2.7^{\mathrm{b}} \pm 0.7$

$1.15^{\mathrm{b}} \pm 0.10$

$1.24^{\mathrm{a}} \pm 0.11$

$5.3^{\mathrm{a}} \pm 1.2$

$4.7^{\mathrm{a}} \pm 1.1$

$4.9^{\mathrm{a}} \pm 1.5$

Crop

C $\quad 1.17^{\mathrm{a}} \pm 1.22$

$$
3.9^{\mathrm{a}} \pm 1.6 \quad 3.2^{\mathrm{a}} \pm 1.4
$$

$3.5^{\mathrm{a}} \pm 1.4$
$3.1^{\mathrm{b}} \pm 0.9$

$1.13^{\mathrm{a}} \pm 0.10$

$6.4^{\mathrm{a}} \pm 2.1$

$4.6^{\mathrm{a}} \pm 0.9$

$3.2^{\mathrm{b}} \pm 1.0$

K $\quad 1.14^{\mathrm{a}} \pm 0.75$

$4.3^{\mathrm{a}} \pm 1.7 \quad 3.0^{\mathrm{a}} \pm 0.9$

$1.14^{\mathrm{a}} \pm 0.09$

$$
5.1^{\mathrm{a}} \pm 1.5
$$

$$
\begin{aligned}
& 4.9^{\mathrm{a}} \pm 0.7 \\
& 2.6^{\mathrm{b}} \pm 0.8
\end{aligned}
$$

$3.7^{\mathrm{a}} \pm 1.5$

\begin{tabular}{|c|c|c|c|c|c|c|c|c|}
\hline $\mathrm{C}^{*} \mathrm{M}$ & $1.10 \pm 0.10$ & $3.3 \pm 1.7$ & $3.9 \pm 0.8$ & $4.4 \pm 1.4$ & $1.10 \pm 0.10$ & $5.4 \pm 1.9$ & $5.0 \pm 0.5$ & $4.0 \pm 1.5$ \\
\hline $\mathrm{K} * \mathrm{M}$ & $1.20 \pm 0.10$ & $3.9 \pm 1.3$ & $3.5 \pm 0.7$ & $3.4 \pm 1.1$ & $1.10 \pm 0.10$ & $3.4 \pm 2.2$ & $2.8 \pm 0.8$ & $3.7 \pm 1.0$ \\
\hline $\mathrm{C} * \mathrm{U}$ & $1.30 \pm 0.10$ & $4.6 \pm 1.2$ & $2.5 \pm 1.4$ & $2.6 \pm 0.7$ & $1.10 \pm 0.10$ & $4.8 \pm 1.0$ & $4.9 \pm 0.8$ & $3.5 \pm 1.3$ \\
\hline $\mathrm{K} * \mathrm{U}$ & $1.20 \pm 0.10$ & $4.6 \pm 2.0$ & $2.6 \pm 0.9$ & $2.8 \pm 0.7$ & $1.20 \pm 0.10$ & $2.3 \pm 1.3$ & $2.5 \pm 0.8$ & $3.3 \pm 0.8$ \\
\hline Grand Mean & $1.16 \pm 0.10$ & $4.1 \pm 1.7$ & $3.1 \pm 1.1$ & $3.3 \pm 1.2$ & $1.19 \pm 0.11$ & $5.8 \pm 2.1$ & $4.6 \pm 1.2$ & $3.6 \pm 1.3$ \\
\hline & \multicolumn{4}{|c|}{ Pr $>\mathbf{F}$} & \multicolumn{4}{|c|}{$\operatorname{Pr}>\mathbf{F}$} \\
\hline & 0.0642 & $<.0001$ & 0.2150 & 0.0367 & 0.7736 & $<.0001$ & 0.0391 & 0.1550 \\
\hline & $<.0001$ & 0.0050 & $<.0001$ & $<.0001$ & 0.0694 & 0.1537 & 0.5412 & 0.0694 \\
\hline & 0.1536 & 0.2709 & 0.6039 & 0.0083 & 0.7252 & 0.0734 & $<.0001$ & 0.0221 \\
\hline${ }^{*}$ Crop & 0.0004 & 0.3802 & 0.3402 & 0.0003 & 0.5157 & 0.0040 & 0.5952 & 0.7334 \\
\hline
\end{tabular}

$4.3^{\mathrm{b}} \pm 2.4$

$3.5^{\mathrm{b}} \pm 0.9$

\section{Manure*Crop}

Manure*Crop

0.0004

0.3802

0.3402

0.7252
0.5157

0.0040

0.5952

0.7334

*Different letters within a column indicate significant difference at $\alpha=0.1$ within factor. Values following the \pm symbol are the standard deviation.

$\mathrm{BD}=$ Bulk Density; DA-GMD=Dry aggregate geometric mean diameter; WA-GMD=Wet aggregate geometric mean diameter; SOM (0-10cm) = Soil organic matter; $\mathrm{M}=$ Manured plots; $\mathrm{U}=\mathrm{Unmanured}$ plots; $\mathrm{C}=\mathrm{Corn}$; $\mathrm{K}=$ Kale. 
Table 4. Within-rotations (4-yr and 7-yr) main effects of manure and crop on 2013 stratified soil $\mathrm{pH}$ (KCl) and soil organic matter (SOM).

\begin{tabular}{|c|c|c|c|c|c|c|c|c|}
\hline \multirow[t]{3}{*}{2013} & \multicolumn{4}{|c|}{ "Rotation 4-yr } & \multicolumn{4}{|c|}{ "Rotation 7-yr } \\
\hline & \multicolumn{2}{|c|}{$\mathrm{pH}(\mathrm{KCL})$} & \multicolumn{2}{|c|}{$\operatorname{SOM}(\%)$} & \multicolumn{2}{|c|}{$\mathrm{pH}(\mathrm{KCl})$} & \multicolumn{2}{|c|}{$\operatorname{SOM}(\%)$} \\
\hline & $0-5 \mathrm{~cm}$ & $5-10 \mathrm{~cm}$ & $0-5 \mathrm{~cm}$ & $5-10 \mathrm{~cm}$ & $0-5 \mathrm{~cm}$ & $5-10 \mathrm{~cm}$ & $0-5 \mathrm{~cm}$ & $5-10 \mathrm{~cm}$ \\
\hline \multicolumn{9}{|l|}{ Composted Manure } \\
\hline M & $5.8^{\mathrm{a}} \pm 0.3$ & $5.8^{\mathrm{a}} \pm 0.3$ & $4.9^{\mathrm{a}} \pm 1.0$ & $4.4^{\mathrm{a}} \pm 0.8$ & $5.9^{\mathrm{a}} \pm 0.3$ & $5.8^{\mathrm{a}} \pm 0.4$ & $5.4^{\mathrm{a}} \pm 0.1$ & $4.0^{\mathrm{a}} \pm 0.8$ \\
\hline $\mathrm{U}$ & $5.0^{\mathrm{b}} \pm 0.4$ & $5.0^{\mathrm{b}} \pm 0.4$ & $3.3^{\mathrm{b}} \pm 0.6$ & $2.7^{\mathrm{b}} \pm 0.6$ & $5.2^{\mathrm{a}} \pm 0.5$ & $5.1^{\mathrm{a}} \pm 0.5$ & $4.1^{\mathrm{b}} \pm 0.8$ & $3.3^{b} \pm 0.7$ \\
\hline \multicolumn{9}{|l|}{ Crop } \\
\hline $\mathrm{C}$ & $5.4^{\mathrm{a}} \pm 0.7$ & $5.4^{\mathrm{a}} \pm 0.6$ & $4.4^{\mathrm{a}} \pm 0.1$ & $3.7^{\mathrm{a}} \pm 0.6$ & $5.6^{\mathrm{a}} \pm 0.3$ & $5.3^{\mathrm{a}} \pm 0.4$ & $5.3^{\mathrm{a}} \pm 0.9$ & $3.8^{\mathrm{a}} \pm 0.8$ \\
\hline $\mathrm{K}$ & $5.4^{\mathrm{a}} \pm 0.4$ & $5.4^{\mathrm{a}} \pm 0.4$ & $3.8^{\mathrm{b}} \pm 0.7$ & $3.4^{\mathrm{b}} \pm 0.7$ & $5.4^{\mathrm{b}} \pm 0.5$ & $5.3^{\mathrm{a}} \pm 0.6$ & $4.1^{b} \pm 0.7$ & $3.5^{\mathrm{b}} \pm 0.8$ \\
\hline \multicolumn{9}{|l|}{ Manure*Crop } \\
\hline $\mathrm{C}^{*} \mathrm{M}$ & $6.0 \pm 0.2$ & $6.0 \pm 0.2$ & $5.6 \pm 0.7$ & $4.9 \pm 0.6$ & $5.7 \pm 0.2$ & $5.5 \pm 0.3$ & $5.7 \pm 0.9$ & $3.7 \pm 0.8$ \\
\hline $\mathrm{K}^{*} \mathrm{M}$ & $5.7 \pm 0.3$ & $5.7 \pm 0.2$ & $4.2 \pm 0.6$ & $3.9 \pm 0.6$ & $5.5 \pm 0.2$ & $5.4 \pm 0.3$ & $4.4 \pm 0.6$ & $3.9 \pm 0.9$ \\
\hline$C^{*} \mathrm{U}$ & $4.8 \pm 0.5$ & $4.9 \pm 0.4$ & $3.3 \pm 0.7$ & $2.5 \pm 0.7$ & $5.5 \pm 0.4$ & $5.1 \pm 0.4$ & $4.9 \pm 0.8$ & $3.2 \pm 0.8$ \\
\hline $\mathrm{K} * \mathrm{U}$ & $5.1 \pm 0.2$ & $5.1 \pm 0.2$ & $3.4 \pm 0.4$ & $2.9 \pm 0.5$ & $5.4 \pm 0.7$ & $5.4 \pm 0.7$ & $3.7 \pm 0.6$ & $3.8 \pm 0.7$ \\
\hline Grand Mean & $5.4 \pm 0.6$ & $5.4 \pm 0.5$ & $4.1 \pm 1.1$ & $3.5 \pm 1.1$ & $5.6 \pm 0.5$ & $5.4 \pm 0.6$ & $4.7 \pm 1.2$ & $3.7 \pm 0.8$ \\
\hline & \multicolumn{8}{|c|}{ Pr $>$ F } \\
\hline Block & 0.0127 & $<.0001$ & 0.0106 & 0.0186 & 0.5107 & 0.0877 & 0.1796 & 0.0292 \\
\hline Composted Manure & $<.0001$ & $<.0001$ & $<.0001$ & $<.0001$ & 0.1090 & 0.1298 & 0.0007 & 0.0923 \\
\hline Crop & 0.7811 & 0.5072 & $<.0001$ & 0.0443 & 0.0681 & 0.6181 & $<.0001$ & 0.0735 \\
\hline Manure*Crop & 0.0009 & 0.0005 & $<.0001$ & $<.0001$ & 0.7148 & 0.1298 & 0.9960 & 0.3825 \\
\hline
\end{tabular}

*Different letters within a column indicate significant difference at $\alpha=0.1$ within factor. Values following the \pm symbol are the standard deviation.

$\mathrm{M}=$ Manured plots; $\mathrm{U}=$ Unmanured plots; $\mathrm{C}=\mathrm{Corn} ; \mathrm{K}=$ Kale. 
Table 5. Within-rotations (4-yr and 7-yr) main effects of manure and crop on 2013 stratified soil test phosphorus (STP) and soil test potassium (STK)

\begin{tabular}{|c|c|c|c|c|c|c|c|c|}
\hline \multirow[t]{3}{*}{2013} & \multicolumn{4}{|c|}{ Rotation 4-yr } & \multicolumn{4}{|c|}{ Rotation 7-yr } \\
\hline & \multicolumn{2}{|c|}{ STP (mg/kg) } & \multicolumn{2}{|c|}{ STK (mg/kg) } & \multicolumn{2}{|c|}{ STP (mg/kg) } & \multicolumn{2}{|c|}{ STK $(\mathrm{mg} / \mathrm{kg})$} \\
\hline & $0-5 \mathrm{~cm}$ & $5-10 \mathrm{~cm}$ & $0-5 \mathrm{~cm}$ & $5-10 \mathrm{~cm}$ & $0-5 \mathrm{~cm}$ & $5-10 \mathrm{~cm}$ & $0-5 \mathrm{~cm}$ & $5-10 \mathrm{~cm}$ \\
\hline \multicolumn{9}{|l|}{ Composted Manure } \\
\hline M & $96.7^{\mathrm{a}} \pm 64$ & $88.0^{\mathrm{a}} \pm 63$ & $201^{a} \pm 76$ & $160.6^{a} \pm 56$ & $70.8^{a} \pm 32.3$ & $45.4^{\mathrm{a}} \pm 20.4$ & $175.4^{\mathrm{a}} \pm 55.2$ & $123.4^{\mathrm{a}} \pm 38.0$ \\
\hline $\mathrm{U}$ & $19.7^{b} \pm 11.2$ & $16.7^{\mathrm{b}} \pm 10.1$ & $111^{b} \pm 26$ & $83.2^{b} \pm 22.8$ & $26.2^{b} \pm 25.6$ & $16.7^{b} \pm 14.9$ & $129.4^{\mathrm{b}} \pm 41.8$ & $91.0^{b} \pm 27.6$ \\
\hline \multicolumn{9}{|l|}{ Crop } \\
\hline $\mathrm{C}$ & $86.9^{a} \pm 71.7$ & $78.2^{\mathrm{a}} \pm 70.3$ & $186^{\mathrm{a}} \pm 88$ & $136.3^{\mathrm{a}} \pm 72.4$ & $72.9^{\mathrm{a}} \pm 32.4$ & $37.5^{\mathrm{a}} \pm 23.0$ & $188.3^{\mathrm{a}} \pm 70.2$ & $118.4^{\mathrm{a}} \pm 55.1$ \\
\hline $\mathrm{K}$ & $29.6^{b} \pm 20.8$ & $26.5^{b} \pm 18.8$ & $126^{\mathrm{b}} \pm 32.8$ & $107.4^{b} \pm 33.1$ & $24.5^{b} \pm 10.1$ & $20.5^{\mathrm{b}} \pm 9.0$ & $125.8^{\mathrm{b}} \pm 35.2$ & $96.5^{b} \pm 22.7$ \\
\hline \multicolumn{9}{|l|}{ Manure*Crop } \\
\hline $\mathrm{C} * \mathrm{M}$ & $150 \pm 45.5$ & $137 \pm 52.9$ & $258 \pm 64$ & $193 \pm 58.7$ & $81.9 \pm 27.6$ & $44.1 \pm 17.2$ & $211.6 \pm 78.6$ & $144 \pm 61.0$ \\
\hline $\mathrm{K} * \mathrm{M}$ & $44.0 \pm 20.6$ & $39.4 \pm 18.0$ & $144 \pm 30$ & $128 \pm 28.3$ & $30.2 \pm 9.7$ & $24.6 \pm 10.1$ & $142.4 \pm 36.7$ & $105 \pm 18.0$ \\
\hline $\mathrm{C} * \mathrm{U}$ & $24.2 \pm 13.5$ & $19.9 \pm 11.8$ & $114 \pm 27$ & $79.6 \pm 22.4$ & $63.9 \pm 35.2$ & $30.9 \pm 26.7$ & $164.9 \pm 53.4$ & $92.4 \pm 33.6$ \\
\hline $\mathrm{K}^{*} \mathrm{U}$ & $15.2 \pm 5.6$ & $13.5 \pm 7.0$ & $108 \pm 25$ & $86.7 \pm 23.5$ & $18.9 \pm 6.9$ & $16.5 \pm 5.6$ & $109.2 \pm 25.2$ & $88.5 \pm 24.5$ \\
\hline Grand Mean & $58.2 \pm 59.8$ & $52.3 \pm 57.3$ & $156 \pm 72.5$ & $121.9 \pm 57.6$ & $48.7 \pm 36.6$ & $31.1 \pm 22.9$ & $152.6 \pm 54.0$ & $107.3 \pm 36.9$ \\
\hline & \multicolumn{8}{|c|}{$\operatorname{Pr}>\mathbf{F}$} \\
\hline Block & $<.0001$ & 0.0003 & 0.6388 & 0.8789 & 0.1536 & 0.9150 & 0.0001 & 0.0113 \\
\hline Composted Manure & $<.0001$ & $<.0001$ & $<.0001$ & $<.0001$ & 0.0155 & 0.0199 & 0.0011 & 0.0005 \\
\hline Crop & $<.0001$ & $<.0001$ & $<.0001$ & 0.0038 & $<.0001$ & 0.0003 & $<.0001$ & 0.0207 \\
\hline Manure*Crop & $<.0001$ & $<.0001$ & $<.0001$ & 0.0004 & 0.5707 & 0.5698 & 0.5623 & 0.0561 \\
\hline
\end{tabular}

*Different letters within a column indicate significant difference at $\alpha=0.1$ within factor. Values following the \pm symbol are the standard deviation.

$\mathrm{M}=$ Manured plots; $\mathrm{L}=$ Unmanured plots; $\mathrm{C}=\mathrm{Corn} ; \mathrm{K}=$ Kale. 
Table 6. Within-rotations (4-yr and 7-yr) main effects of manure and crop on 2013 stratified soil test calcium (STCa) and soil test magnesium (STMg).

\begin{tabular}{|c|c|c|c|c|c|c|c|c|}
\hline \multirow[t]{3}{*}{2013} & \multicolumn{4}{|c|}{ Rotation 4-yr } & \multicolumn{4}{|c|}{ Rotation 7-yr } \\
\hline & \multicolumn{2}{|c|}{$\mathrm{STCa}(\mathrm{mg} / \mathrm{kg})$} & \multicolumn{2}{|c|}{ STMg $(\mathrm{mg} / \mathrm{kg})$} & \multicolumn{2}{|c|}{$\mathrm{STCa}(\mathrm{mg} / \mathrm{kg})$} & \multicolumn{2}{|c|}{ STMg $(\mathrm{mg} / \mathrm{kg})$} \\
\hline & $0-5 \mathrm{~cm}$ & $5-10 \mathrm{~cm}$ & $0-5 \mathrm{~cm}$ & $5-10 \mathrm{~cm}$ & $0-5 \mathrm{~cm}$ & $5-10 \mathrm{~cm}$ & $0-5 \mathrm{~cm}$ & $5-10 \mathrm{~cm}$ \\
\hline \multicolumn{9}{|l|}{$\begin{array}{l}\text { Composted } \\
\text { Manure }\end{array}$} \\
\hline tentes & $2164^{\mathrm{a}} \pm 571$ & $2204^{a} \pm 613$ & $159^{\mathrm{a}} \pm 33.4$ & $155^{\mathrm{a}} \pm 30.3$ & $2285^{\mathrm{a}} \pm 538$ & $2184^{a} \pm 599$ & $172.9^{\mathrm{a}} \pm 42.8$ & $149.9^{\mathrm{a}} \pm 42.1$ \\
\hline $\mathrm{U}$ & $1481^{b} \pm 636$ & $1549^{b} \pm 607$ & $113^{b} \pm 36.2$ & $107^{\mathrm{b}} \pm 36.2$ & $1662^{\mathrm{b}} \pm 521$ & $1655^{b} \pm 601$ & $144.8^{\mathrm{a}} \pm 42.5$ & $125.6^{\mathrm{a}} \pm 45.5$ \\
\hline \multicolumn{9}{|l|}{ Crop } \\
\hline $\mathrm{C}$ & $1939^{\mathrm{a}} \pm 843$ & $2016^{a} \pm 803$ & $137^{\mathrm{a}} \pm 44.2$ & $132.2^{\mathrm{a}} \pm 41.7$ & $1930^{\mathrm{a}} \pm 454$ & $1777^{a} \pm 569$ & $174.5^{\mathrm{a}} \pm 35.2$ & $130.4^{\mathrm{b}} \pm 34.5$ \\
\hline $\mathrm{K}$ & $1707^{\mathrm{b}} \pm 483$ & $1737^{b} \pm 531$ & $135^{\mathrm{a}} \pm 38.7$ & $129.7^{\mathrm{a}} \pm 40.8$ & $1750^{b} \pm 593$ & $1777^{a} \pm 680$ & $153.1^{\mathrm{a}} \pm 38.7$ & $142.5^{\mathrm{a}} \pm 40.0$ \\
\hline \multicolumn{9}{|l|}{ Manure*Crop } \\
\hline $\mathrm{C} * \mathrm{M}$ & $2442 \pm 455.9$ & $2493 \pm 459.9$ & $165.2 \pm 34.6$ & $160.9 \pm 30.3$ & $2142 \pm 428$ & $2043 \pm 572$ & $148.8 \pm 37.6$ & $124.4 \pm 37.7$ \\
\hline $\mathrm{K} * \mathrm{M}$ & $1887 \pm 549.1$ & $1915 \pm 623.5$ & $152.0 \pm 30.5$ & $149.2 \pm 29.2$ & $1811 \pm 488$ & $1770 \pm 460$ & $130.9 \pm 25.2$ & $112.6 \pm 27.6$ \\
\hline $\mathrm{C} * \mathrm{U}$ & $1436 \pm 849.7$ & $1540 \pm 797.9$ & $108.7 \pm 33.7$ & $103.4 \pm 30.2$ & $1735 \pm 394$ & $1498 \pm 429$ & $112.1 \pm 18.1$ & $87.9 \pm 17.8$ \\
\hline $\mathrm{K}^{*} \mathrm{U}$ & $1527 \pm 336.5$ & $1559 \pm 355.9$ & $117.8 \pm 39.2$ & $110.3 \pm 42.1$ & $1688 \pm 695$ & $1783 \pm 864$ & $154.1 \pm 49.0$ & $130.1 \pm 44.5$ \\
\hline Grand Mean & $1822.7 \pm 691$ & $1876.6 \pm 689$ & $135.9 \pm 41.2$ & $131.0 \pm 40.9$ & $1975.8 \pm 613$ & $1920.9 \pm 654$ & $158.9 \pm 44.6$ & $137.9 \pm 45.3$ \\
\hline & \multicolumn{8}{|c|}{$\operatorname{Pr}>\mathbf{F}$} \\
\hline Block & $<.0001$ & $<.0001$ & $<.0001$ & $<.0001$ & $<.0001$ & $<.0001$ & 0.0457 & 0.0122 \\
\hline Composted Manure & $<.0001$ & $<.0001$ & $<.0001$ & $<.0001$ & 0.0193 & 0.0386 & 0.4966 & 0.4205 \\
\hline Crop & 0.0241 & 0.0071 & 0.7721 & 0.7355 & 0.0913 & 0.9599 & 0.0164 & 0.1555 \\
\hline Manure*Crop & 0.0021 & 0.0041 & 0.1227 & 0.1988 & 0.2004 & 0.0303 & 0.0034 & 0.0008 \\
\hline
\end{tabular}

*Different letters within a column indicate significant difference at $\alpha=0.1$ within factor. Values following the \pm symbol are the standard deviation.

$\mathrm{M}=$ Manured plots; $\mathrm{L}=$ Unmanured plots; $\mathrm{C}=\mathrm{Corn}$; $\mathrm{K}=$ Kale. 
Table 7. Within-rotations (4-yr and 7-yr) main effects of manure and crop on 2013 stratified soil test zinc (STZn) and total nitrogen (TotN).

\begin{tabular}{|c|c|c|c|c|c|c|c|c|}
\hline \multirow[t]{3}{*}{2013} & \multicolumn{4}{|c|}{$\begin{array}{ll}\text { Rotation 4-yr }\end{array}$} & \multicolumn{4}{|c|}{ Rotation 7-yr } \\
\hline & \multicolumn{2}{|c|}{$\mathrm{STZn}(\mathrm{mg} / \mathrm{kg})$} & \multicolumn{2}{|c|}{$\operatorname{Tot} N(\mathrm{~g} / \mathrm{kg})$} & \multicolumn{2}{|c|}{ STZn (mg/kg) } & \multicolumn{2}{|c|}{ TotN $(\mathrm{g} / \mathrm{kg})$} \\
\hline & $0-5 \mathrm{~cm}$ & $5-10 \mathrm{~cm}$ & $0-5 \mathrm{~cm}$ & $5-10 \mathrm{~cm}$ & $0-5 \mathrm{~cm}$ & $5-10 \mathrm{~cm}$ & $0-5 \mathrm{~cm}$ & $5-10 \mathrm{~cm}$ \\
\hline \multicolumn{9}{|l|}{ Composted Manure } \\
\hline M & $5.9^{\mathrm{a}} \pm 2.4$ & $5.5^{\mathrm{a}} \pm 2.4$ & $2.7^{\mathrm{a}} \pm 0.5$ & $2.4^{\mathrm{a}} \pm 0.4$ & $5.6^{\mathrm{a}} \pm 1.8$ & $4.2^{\mathrm{a}} \pm 1.5$ & $2.9^{\mathrm{a}} \pm 0.6$ & $2.2^{\mathrm{a}} \pm 0.4$ \\
\hline $\mathrm{U}$ & $2.3^{\mathrm{b}} \pm 1.4$ & $2.2^{\mathrm{b}} \pm 1.8$ & $1.7^{\mathrm{b}} \pm 0.3$ & $1.2^{\mathrm{b}} \pm 0.3$ & $3.5^{\mathrm{b}} \pm 2.9$ & $2.9^{b} \pm 2.6$ & $2.2^{\mathrm{b}} \pm 0.4$ & $1.8^{\mathrm{b}} \pm 0.3$ \\
\hline \multicolumn{9}{|l|}{ Crop } \\
\hline $\mathrm{C}$ & $4.8^{\mathrm{a}} \pm 3.2$ & $4.6^{\mathrm{a}} \pm 3.3$ & $2.3^{\mathrm{a}} \pm 0.8$ & $1.9^{\mathrm{a}} \pm 0.8$ & $6.1^{\mathrm{a}} \pm 3.7$ & $4.1^{\mathrm{a}} \pm 3.6$ & $2.8^{\mathrm{a}} \pm 0.4$ & $1.9^{\mathrm{a}} \pm 0.4$ \\
\hline $\mathrm{K}$ & $3.3^{\mathrm{b}} \pm 1.5$ & $3.1^{\mathrm{b}} \pm 1.6$ & $2.0^{\mathrm{b}} \pm 2.0$ & $1.9^{\mathrm{a}} \pm 1.9$ & $3.3^{\mathrm{b}} \pm 1.0$ & $3.0^{\mathrm{a}} \pm 1.0$ & $2.2^{\mathrm{b}} \pm 0.3$ & $1.9^{\mathrm{a}} \pm 0.3$ \\
\hline \multicolumn{9}{|l|}{ Manure*Crop } \\
\hline $\mathrm{C}^{*} \mathrm{M}$ & $7.5 \pm 1.7$ & $7.0 \pm 1.9$ & $3.1 \pm 0.4$ & $2.6 \pm 0.3$ & $5.7 \pm 1.2$ & $3.8 \pm 1.2$ & $3.0 \pm 0.4$ & $2.1 \pm 0.4$ \\
\hline $\mathrm{K}^{*} \mathrm{M}$ & $4.2 \pm 1.7$ & $4.0 \pm 1.8$ & $2.3 \pm 0.3$ & $2.1 \pm 0.3$ & $3.3 \pm 0.6$ & $2.9 \pm 0.7$ & $2.3 \pm 0.3$ & $2.1 \pm 0.3$ \\
\hline $\mathrm{C} * \mathrm{U}$ & $2.2 \pm 1.9$ & $2.2 \pm 2.5$ & $1.6 \pm 0.3$ & $1.3 \pm 0.4$ & $6.4 \pm 5.2$ & $4.4 \pm 5.0$ & $2.6 \pm 0.4$ & $1.8 \pm 0.4$ \\
\hline $\mathrm{K}^{*} \mathrm{U}$ & $2.4 \pm 0.6$ & $2.3 \pm 0.6$ & $1.8 \pm 0.2$ & $1.6 \pm 0.2$ & $3.2 \pm 1.4$ & $3.1 \pm 1.3$ & $2.0 \pm 0.3$ & $1.9 \pm 0.3$ \\
\hline Grand Mean & $4.1 \pm 2.6$ & $3.9 \pm 2.6$ & $2.2 \pm 0.7$ & $1.9 \pm 0.6$ & $4.6 \pm 2.6$ & $3.6 \pm 2.2$ & $2.5 \pm 0.6$ & $2.0 \pm 0.4$ \\
\hline & \multicolumn{8}{|c|}{$\operatorname{Pr}>\mathbf{F}$} \\
\hline Block & 0.0257 & 0.1300 & 0.0091 & 0.0042 & 0.3431 & 0.1664 & 0.1751 & 0.0931 \\
\hline Composted Manure & $<.0001$ & $<.0001$ & $<.0001$ & $<.0001$ & 0.6927 & 0.6143 & 0.0003 & 0.0142 \\
\hline Crop & 0.0002 & 0.0026 & 0.0001 & 0.3093 & 0.0003 & 0.1102 & $<.0001$ & 0.5883 \\
\hline Manure*Crop & $<.0001$ & 0.0022 & $<.0001$ & $<.0001$ & 0.6033 & 0.7802 & 0.8312 & 0.4483 \\
\hline
\end{tabular}

$*$ Different letters within a column indicate significant difference at $\alpha=0.1$ within factor. Values following the \pm symbol are the standard deviation. $\mathrm{M}=$ Manured plots; $\mathrm{U}=\mathrm{Unmanured} \mathrm{plots;} \mathrm{C}=\mathrm{Corn} ; \mathrm{K}=$ Kale. 
2013 Between-Rotation Effect of Manure and Rotation on Physical and Chemical Quality, and Biomass

In this section, the effect of manure and rotation within crop and between rotations on 2013 soil physical property values will be discussed: bulk density (BD), dry geometric mean diameter aggregation (DA-GMD), wet geometric mean diameter aggregation (WA-GMD), and soil organic matter at $0-10 \mathrm{~cm}$ depth (SOM) (Table 4). Stratified bioavailable nutrients discussed, for the depths 0-5 and 5-10cm, are $\mathrm{pH}$, soil organic matter (SOM), soil test phosphorus (STP), soils test potassium (STK), soil test calcium (STCa), soil test magnesium (STMg), soil test zinc (STZn), and total nitrogen (TotN) (Tables 9, 10, 11, 12). The effects of manure and rotation on 2013 cowpea biomass measurements are discussed below (Table 14). Due to germination problems and inconsistency with the 2013 corn stand, these data are omitted in the discussion. Statistical analyses were not able to be performed on these data, as means for treatments were not representative due to poor emergence, plant damage, and weed domination.

The rotation design included the planting of cowpea as a summer cover crop after kale was harvested in the spring. Due to the planting of cowpeas after the kale harvest in spring, in this experiment cowpea biomass was selected as indicator of the productivity of the "kale" plots. The cowpea crop was allowed to grow in summer, and was harvested in September 2013 and 2014. Weeds and cowpeas were harvested to assess the overall productivity of the plots. The sampling performed in this study separates weeds biomass from cowpeas biomass.

\section{Manure effect between rotation type (4yr and 7-yr)}

In 2013, BD values were significantly affected by manure addition in the first crop of the rotation (corn) and in the last crop of the rotation (kale) (Table 8). In both crops, plots receiving composted manure exhibited significantly lower bulk density than plots receiving no composted manure. Dry aggregate stability (GMD) values were significantly larger in kale plots not receiving composted manure than those receiving composted manure, regardless of rotation type. No significant difference was observed between manured and unmanured corn plots (Table 8). Regardless of crop, wet aggregate stability (WA-GMD) was greater in plots receiving composted 
manure than in plots receiving no manure. Soil organic matter (SOM) values were significantly higher in manured corn and kale plots than in unmanured plots (Table 8).

Soil $\mathrm{pH}$ values between $0-10 \mathrm{~cm}$ in depth were significantly affected by composted manure addition, regardless of crop (Table 9). In all cases, soil $\mathrm{pH}$ was higher in manured plots than in unmanured plots. All nutrients at all depths (except STCa at the 5-10cm depth, STMG at all depths, and Tot $\mathrm{N}(0-5 \mathrm{~cm})$ were statistically affected by manure application regardless of crop; higher manure application corresponded to higher nutrient in the soil (Tables 9, 10, 11, 12).

Cowpea biomass and total biomass (weeds + cowpeas) were significantly affected by manure application (Table 14). Manured plots had greater biomass values than unmanured plots.

\section{Rotation effect between rotation type (4yr and 7-yr) within crop component}

A significant effect of rotation cycle on bulk density was observed in the corn plots, but not in kale plots. Corn plots in the 7-yr cycle had significantly lower bulk density than corn plots in the 4-yr cycle (Table 8). DA-GMD was significantly higher in the 7-year rotation corn plots, compared to the 4-year corn plots. No significant effect of rotation cycle was observed in kale plots. Rotation had a statistically significant effect on wet aggregate stability for corn and kale plots. Wet aggregate stability was significantly higher in the 7-year rotation cycle corn plots than 7-yr kale plots, while the opposite was true for kale plots (Table 8). A significant effect of rotation cycle on SOM (0-10 cm depth) was observed in the kale plots, but not in corn plots. Kale plots in the 7-yr cycle had significantly higher SOM than kale plots in the 4-yr cycle.

For $\mathrm{pH}$, a significant effect of rotation was only observed in the surface depth $(0-5 \mathrm{~cm})$ in corn, indicating that on average the soil $\mathrm{pH}$ was significantly higher in 7 -yr plots $(\mathrm{pH}=5.6)$ than in the 4-yr plots $(\mathrm{pH}=5.4)$. When comparing stratified SOM between the first and last crop of the rotation, a significant effect of rotation was observed at the $0-5 \mathrm{~cm}$ depth for the corn plots, and at all depths for kale. Soil test phosphorus (STP) (0-10cm depth) was statistically significantly higher in the 4-yr rotation than in the 7-yr rotation (Table 10). Soil test potassium (STK) (5$10 \mathrm{~cm}$ ) was also statistically significantly higher in the 4-yr rotation than in the 7-yr rotation. A significant effect of rotation was only observed at the 5-10cm depth in corn plots for Soil test calcium (STCa) (Table 11). In these plots, STCa was statistically significantly higher in the 4-yr plots than in the 7-yr plots. A significant effect of rotation on STMg was observed regardless of 
crop, but only at the $0-5 \mathrm{~cm}$ depth. In both cases, 7-yr STMg values were higher than those in the $4-\mathrm{yr}$ rotation. There was no significant effect of rotation on $\mathrm{STZn}(0-10 \mathrm{~cm})$ and $\mathrm{TotN}(5-10 \mathrm{~cm})$ in corn or kale. However there was a significant effect of rotation on TotN $(0-5 \mathrm{~cm})$ regardless of crop; in both cases the 7-yr rotation exhibited higher nitrogen concentration than the 4-yr rotation. Cowpea biomass, weed biomass, and total biomass (weeds + cowpeas) were not significantly affected by rotation (Table 14).

\section{Interactions between manure and rotation type within crop component}

There is a highly significant interaction between manure and rotation only for corn; the effect of not applying manure resulted in a higher BD in the 4-yr rotation than in the 7-yr rotation. An interaction for DA-GMD was observed between manure and rotation in corn plots, but not in kale plots (Table 8). For corn, a decrease in DA-GMD with increase in manure rate was observed in the 7-yr rotation, while the opposite was observed for the 4-yr rotation. An interaction was observed for WA-GMD between manure and rotation in corn plots, but not in kale plots. Although no main effect of rotation was observed on SOM for corn, an interaction was observed between manure and rotation. Kale plots did not show any interaction between manure and rotation (Table 8).

An interaction was observed between manure and rotation on soil $\mathrm{pH}$ and $\mathrm{SOM}$ in corn and kale plots at all depths (Table 9). An interaction was observed between manure and rotation regardless of crop for STP $(0-10 \mathrm{~cm})$. This interaction revealed that although the STP was higher in manured plots in the 4-yr rotation, STP was higher in the unmanured plots for the 7-yr rotation. STK for corn $(0-10 \mathrm{~cm})$ and for kale $(5-10 \mathrm{~cm})$ exhibited the same statistically significant interaction as the one previously described. A significant effect of block was observed on STCa values in corn and kale plots at all depths. An interaction was observed between manure and rotation in corn plots at the $0-5 \mathrm{~cm}$ and $5-10 \mathrm{~cm}$ depths. An interaction was observed between manure and rotation for STMg, but only in kale plots (Table 11). Manure by rotation interaction was observed for STZN $(0-10 \mathrm{~cm})$ and TotN $(5-10 \mathrm{~cm})$ regardless of the crop (Table 12). No interaction was observed for TotN $(0-5 \mathrm{~cm})$ for kale. Neither an interaction nor an effect of block was observed between rotation and manure for cowpea biomass values (Table 14). 
Table 8: 2013 Between-Rotations main effects of manure and rotation (4-yr and 7-yr) on soil physical quality indicators under the first (corn) and last (kale) crop component of the rotation.

\begin{tabular}{|c|c|c|c|c|c|c|c|c|}
\hline \multirow[b]{2}{*}{2013 Variables } & \multicolumn{4}{|c|}{ Corn } & \multicolumn{4}{|c|}{ Kale } \\
\hline & $\begin{array}{c}\mathrm{BD} \\
\mathrm{Mg} / \mathrm{m}^{3}\end{array}$ & $\begin{array}{c}\text { DA-GMD } \\
\mathrm{mm}\end{array}$ & $\begin{array}{c}\text { WA-GMD } \\
\mathrm{mm}\end{array}$ & $\begin{array}{c}\text { SOM } \\
\% \\
\end{array}$ & $\begin{array}{c}\mathrm{BD} \\
\mathrm{Mg} / \mathrm{m}^{3}\end{array}$ & $\begin{array}{c}\text { DA-GMD } \\
\mathrm{mm}\end{array}$ & $\begin{array}{c}\text { WA-GMD } \\
\mathrm{mm}\end{array}$ & $\begin{array}{c}\mathrm{SOM} \\
\% \\
\end{array}$ \\
\hline \multicolumn{9}{|l|}{ Manure } \\
\hline M & $1.09^{\mathrm{b}} \pm 0.09$ & $4.3^{\mathrm{a}} \pm 2.1$ & $4.4^{\mathrm{a}} \pm 0.9$ & $4.2^{\mathrm{a}} \pm 1.5$ & $1.11^{\mathrm{b}} \pm 0.07$ & $3.7^{\mathrm{b}} \pm 1.8$ & $3.1^{\mathrm{a}} \pm 0.8$ & $3.6^{\mathrm{a}} \pm 1.0$ \\
\hline $\mathrm{U}$ & $1.21^{\mathrm{a}} \pm 0.10$ & $4.7^{\mathrm{a}} \pm 1.07$ & $3.7^{\mathrm{b}} \pm 1.7$ & $3.1^{\mathrm{b}} \pm 1.2$ & $1.17^{\mathrm{a}} \pm 0.09$ & $5.0^{\mathrm{a}} \pm 2.2$ & $2.6^{\mathrm{b}} \pm 0.9$ & $3.1^{\mathrm{b}} \pm 0.8$ \\
\hline \multicolumn{9}{|l|}{ Rotation Cycle } \\
\hline $4-\mathrm{yr}$ & $1.17^{\mathrm{a}} \pm 0.12$ & $3.9^{\mathrm{b}} \pm 1.6$ & $3.2^{\mathrm{b}} \pm 1.4$ & $3.5^{\mathrm{a}} \pm 1.4$ & $1.14^{\mathrm{a}} \pm 0.08$ & $4.3^{\mathrm{a}} \pm 1.7$ & $3.0^{\mathrm{a}} \pm 0.9$ & $3.1^{\mathrm{b}} \pm 1.0$ \\
\hline $7-\mathrm{yr}$ & $1.13^{\mathrm{b}} \pm 0.10$ & $5.1^{\mathrm{a}} \pm 1.5$ & $4.9^{\mathrm{a}} \pm 0.7$ & $3.7^{\mathrm{a}} \pm 1.5$ & $1.14^{\mathrm{a}} \pm 0.09$ & $4.4^{\mathrm{a}} \pm 2.4$ & $2.7^{\mathrm{b}} \pm 0.8$ & $3.5^{\mathrm{a}} \pm 0.9$ \\
\hline \multicolumn{9}{|l|}{ Manure*Rotation } \\
\hline $\mathrm{M}^{* 4-\mathrm{yr}}$ & $1.10 \pm 0.10$ & $3.3 \pm 1.7$ & $3.9 \pm 0.8$ & $4.4 \pm 1.4$ & $1.10 \pm 0.10$ & $3.9 \pm 1.3$ & $3.5 \pm 0.7$ & $3.4 \pm 1.1$ \\
\hline $\mathrm{M} * 7-\mathrm{yr}$ & $1.10 \pm 0.10$ & $5.4 \pm 1.9$ & $5.0 \pm 0.5$ & $4.0 \pm 1.5$ & $1.10 \pm 0.10$ & $3.4 \pm 2.2$ & $2.8 \pm 0.8$ & $3.7 \pm 1.0$ \\
\hline $\mathrm{U}^{* 4-\mathrm{yr}}$ & $1.30 \pm 0.10$ & $4.6 \pm 1.2$ & $2.5 \pm 1.4$ & $2.6 \pm 0.7$ & $1.20 \pm 0.10$ & $4.6 \pm 2.0$ & $2.6 \pm 0.9$ & $2.8 \pm 0.7$ \\
\hline $\mathrm{U} * 7-\mathrm{yr}$ & $1.10 \pm 0.10$ & $4.8 \pm 1.0$ & $4.9 \pm 0.8$ & $3.5 \pm 1.3$ & $1.20 \pm 0.10$ & $5.3 \pm 2.3$ & $2.5 \pm 0.8$ & $3.3 \pm 0.8$ \\
\hline Grand Mean & $1.15 \pm 0.11$ & $4.5 \pm 1.7$ & $4.0 \pm 1.4$ & $3.6 \pm 1.5$ & $1.14 \pm 0.08$ & $4.3 \pm 2.06$ & $2.8 \pm 0.9$ & $3.3 \pm 1.0$ \\
\hline & \multicolumn{4}{|c|}{$\operatorname{Pr}>\mathbf{F}$} & \multicolumn{4}{|c|}{ Pr $>$ F } \\
\hline Block & 0.3812 & $<.0001$ & 0.2893 & 0.1688 & 0.5589 & $<.0001$ & 0.0821 & 0.0160 \\
\hline Manure & $<.0001$ & 0.3169 & 0.0047 & $<.0001$ & 0.0084 & 0.0039 & 0.0069 & 0.0001 \\
\hline Rotation & 0.0925 & 0.0005 & $<.0001$ & 0.2345 & 0.8365 & 0.8938 & 0.0464 & 0.0026 \\
\hline Manure*Rotation & 0.0010 & 0.0039 & 0.0128 & 0.0007 & 0.7919 & 0.1776 & 0.1259 & 0.2073 \\
\hline
\end{tabular}

*Different letters within a column indicate significant difference at $\alpha=0.1$ within factor. Values following the \pm symbol are the standard deviation.

$\mathrm{BD}=$ Bulk Density; DA-GMD=Dry aggregate geometric mean diameter; WA-GMD=Wet aggregate geometric mean diameter; $S O M(0-10 \mathrm{~cm})=$ Soil organic matter; $\mathrm{M}=$ Manured plots; $\mathrm{U}=$ Unmanured plot. 
Table 9. Main effects of manure and rotation (4-yr and 7-yr) on stratified 2013 stratified soil $\mathrm{pH}(\mathrm{KCl})$ and soil organic matter (SOM) under the first (corn) and last (kale) crop component of the rotation.

\begin{tabular}{|c|c|c|c|c|c|c|c|c|}
\hline \multirow[t]{3}{*}{2013} & \multicolumn{4}{|c|}{ Corn } & \multicolumn{4}{|c|}{ Kale } \\
\hline & \multicolumn{2}{|c|}{$\mathrm{pH}(\mathrm{KCL})$} & \multicolumn{2}{|c|}{$\operatorname{SOM}(\%)$} & \multicolumn{2}{|c|}{$\mathrm{pH}(\mathrm{KCl})$} & \multicolumn{2}{|c|}{$\operatorname{SOM}(\%)$} \\
\hline & $0-5 \mathrm{~cm}$ & $5-10 \mathrm{~cm}$ & $0-5 \mathrm{~cm}$ & $5-10 \mathrm{~cm}$ & $0-5 \mathrm{~cm}$ & $5-10 \mathrm{~cm}$ & $0-5 \mathrm{~cm}$ & $5-10 \mathrm{~cm}$ \\
\hline \multicolumn{9}{|l|}{ Composted Manure } \\
\hline 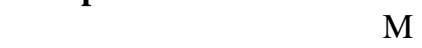 & $5.9^{\mathrm{a}} \pm 0.2$ & $5.7^{\mathrm{a}} \pm 0.3$ & $5.7^{\mathrm{a}} \pm 0.8$ & $4.3^{\mathrm{a}} \pm 0.9$ & $5.6^{\mathrm{a}} \pm 0.2$ & $5.5^{\mathrm{a}} \pm 0.3$ & $4.3^{\mathrm{a}} \pm 0.6$ & $3.9^{\mathrm{a}} \pm 0.7$ \\
\hline $\mathrm{U}$ & $5.2^{b} \pm 0.6$ & $5.0^{\mathrm{b}} \pm 0.4$ & $4.1^{b} \pm 1.2$ & $2.9^{\mathrm{b}} \pm 0.8$ & $5.2^{\mathrm{b}} \pm 0.5$ & $5.2^{\mathrm{b}} \pm 0.6$ & $3.6^{\mathrm{b}} \pm 0.5$ & $3.3^{\mathrm{b}} \pm 0.7$ \\
\hline \multicolumn{9}{|l|}{ Rotation Cycle } \\
\hline $4-\mathrm{yr}$ & $5.4^{\mathrm{b}} \pm 0.7$ & $5.4^{\mathrm{a}} \pm 0.6$ & $4.5^{\mathrm{b}} \pm 1.4$ & $3.7^{\mathrm{a}} \pm 1.4$ & $5.4^{\mathrm{a}} \pm 0.4$ & $5.4^{\mathrm{a}} \pm 0.4$ & $3.8^{\mathrm{b}} \pm 0.7$ & $3.4^{\mathrm{b}} \pm 0.7$ \\
\hline $7-\mathrm{yr}$ & $5.6^{\mathrm{a}} \pm 0.3$ & $5.3^{\mathrm{a}} \pm 0.4$ & $5.3^{\mathrm{a}} \pm 0.9$ & $3.5^{\mathrm{a}} \pm 0.8$ & $5.4^{\mathrm{a}} \pm 0.4$ & $5.4^{\mathrm{a}} \pm 0.6$ & $4.1^{\mathrm{a}} \pm 0.7$ & $3.8^{\mathrm{a}} \pm 0.8$ \\
\hline \multicolumn{9}{|l|}{ Manure*Rotation } \\
\hline $\mathrm{M} * 4-\mathrm{yr}$ & $6.0 \pm 0.2$ & $6.0 \pm 0.2$ & $5.7 \pm 0.7$ & $4.9 \pm 0.6$ & $5.7 \pm 0.3$ & $5.7 \pm 0.2$ & $4.2 \pm 0.6$ & $3.9 \pm 0.6$ \\
\hline $\mathrm{M} * 7-\mathrm{yr}$ & $5.7 \pm 0.2$ & $5.5 \pm 0.3$ & $5.7 \pm 0.9$ & $3.7 \pm 0.8$ & $5.5 \pm 0.2$ & $5.4 \pm 0.3$ & $4.5 \pm 0.7$ & $3.9 \pm 0.9$ \\
\hline $\mathrm{U} * 4-\mathrm{yr}$ & $4.8 \pm 0.5$ & $4.9 \pm 0.4$ & $3.3 \pm 0.7$ & $2.5 \pm 0.7$ & $5.1 \pm 0.2$ & $5.1 \pm 0.2$ & $3.4 \pm 0.4$ & $2.9 \pm 0.5$ \\
\hline $\mathrm{U}^{* 7-y r}$ & $5.5 \pm 0.4$ & $5.2 \pm 0.4$ & $4.9 \pm 0.9$ & $3.2 \pm 0.8$ & $5.4 \pm 0.7$ & $5.4 \pm 0.7$ & $3.8 \pm 0.6$ & $3.8 \pm 0.7$ \\
\hline Grand Mean & $5.5 \pm 0.6$ & $5.4 \pm 0.5$ & $4.9 \pm 1.3$ & $3.6 \pm 1.1$ & $5.4 \pm 0.4$ & $5.4 \pm 0.5$ & $3.9 \pm 0.7$ & $3.6 \pm 0.8$ \\
\hline & \multicolumn{8}{|c|}{$\operatorname{Pr}>\mathbf{F}$} \\
\hline Block & 0.2774 & 0.2975 & 0.0827 & 0.0272 & 0.0041 & 0.0314 & 0.0005 & 0.0562 \\
\hline Composted Manure & $<.0001$ & $<.0001$ & $<.0001$ & $<.0001$ & 0.0004 & 0.0058 & $<.0001$ & 0.0023 \\
\hline Rotation Cycle & 0.0104 & 0.3319 & $<.0001$ & 0.2335 & 0.4796 & 0.8797 & 0.0096 & 0.0123 \\
\hline Manure* Rotation & $<.0001$ & 0.0001 & 0.0001 & $<.0001$ & 0.0237 & 0.0058 & 0.6231 & 0.0293 \\
\hline
\end{tabular}

*Different letters within a column indicate significant difference at $\alpha=0.1$ within factor. Values following the \pm symbol are the standard deviation.

M=Manured plots; U=Unmanured plots. 
Table 10. Main effects of manure and rotation (4-yr and 7-yr) on 2013 stratified soil test phosphorus (STP) and soil test potassium (STK) under the first (corn) and last (kale) crop component of the rotation.

\begin{tabular}{|c|c|c|c|c|c|c|c|c|}
\hline \multirow[t]{3}{*}{2013} & \multicolumn{4}{|c|}{ 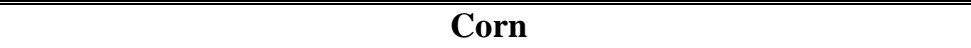 } & \multicolumn{4}{|c|}{ Kale } \\
\hline & \multicolumn{2}{|c|}{$\mathrm{STP}(\mathrm{mg} / \mathrm{kg})$} & \multicolumn{2}{|c|}{$\mathrm{STK}(\mathrm{mg} / \mathrm{kg})$} & \multicolumn{2}{|c|}{$\mathrm{STP}(\mathrm{mg} / \mathrm{kg})$} & \multicolumn{2}{|c|}{ STK $(\mathrm{mg} / \mathrm{kg})$} \\
\hline & $0-5 \mathrm{~cm}$ & $5-10 \mathrm{~cm}$ & $0-5 \mathrm{~cm}$ & $5-10 \mathrm{~cm}$ & $0-5 \mathrm{~cm}$ & $5-10 \mathrm{~cm}$ & $0-5 \mathrm{~cm}$ & $5-10 \mathrm{~cm}$ \\
\hline \multicolumn{9}{|l|}{ Composted Manure } \\
\hline $\mathrm{M}$ & $115.9^{\mathrm{a}} \pm 50.5$ & $90.3^{\mathrm{a}} \pm 60.8$ & $234.8^{\mathrm{a}} \pm 74.5$ & $169^{a} \pm 63.8$ & $37.1^{\mathrm{a}} \pm 17.3$ & $32.0^{\mathrm{a}} \pm 16.2$ & $143^{\mathrm{a}} \pm 32.9$ & $116.3^{\mathrm{a}} \pm 26.2$ \\
\hline $\mathrm{U}$ & $44.1^{\mathrm{b}} \pm 33.0$ & $25.4^{\mathrm{b}} \pm 21.0$ & $139.3^{\mathrm{b}} \pm 49.1$ & $86.0^{\mathrm{b}} \pm 28.8$ & $17.0^{\mathrm{b}} \pm 6.4$ & $15.0^{\mathrm{b}} \pm 6.4$ & $108^{\mathrm{b}} \pm 24.7$ & $87.6^{b} \pm 23.6$ \\
\hline \multicolumn{9}{|l|}{ Rotation Cycle } \\
\hline $4-y r$ & $86.9^{a} \pm 72$ & $78.2^{\mathrm{a}} \pm 70$ & $185.8^{\mathrm{a}} \pm 88$ & $136.3^{\mathrm{a}} \pm 72$ & $29.6^{a} \pm 21$ & $26.5^{\mathrm{a}} \pm 19$ & $125.6^{\mathrm{a}} \pm 33$ & $107.4^{\mathrm{a}} \pm 33$ \\
\hline $7-y r$ & $72.9^{b} \pm 32$ & $37.5^{b} \pm 23$ & $188.3^{a} \pm 70$ & $118.4^{\mathrm{a}} \pm 55$ & $24.5^{\mathrm{b}} \pm 10$ & $20.5^{\mathrm{b}} \pm 9$ & $125.8^{\mathrm{a}} \pm 35$ & $96.5^{\mathrm{b}} \pm 23$ \\
\hline \multicolumn{9}{|l|}{ Manure*Rotation } \\
\hline$M^{* 4-y r}$ & $149.5 \pm 45.5$ & $136.5 \pm 52.9$ & $257.9 \pm 64.5$ & $193 \pm 58.7$ & $44 \pm 20.6$ & $39.4 \pm 18.0$ & $144 \pm 30.0$ & $128 \pm 28.3$ \\
\hline M*7-yr & $81.9 \pm 27.6$ & $44.1 \pm 17.2$ & $211.6 \pm 78.6$ & $144 \pm 61.0$ & $30.2 \pm 9.7$ & $24.6 \pm 10.1$ & $142 \pm 36.7$ & $105 \pm 18.0$ \\
\hline $\mathrm{U} * 4-\mathrm{yr}$ & $24.2 \pm 13.5$ & $19.9 \pm 11.8$ & $113.6 \pm 26.9$ & $79.6 \pm 22.4$ & $15.2 \pm 5.6$ & $13.5 \pm 7.0$ & $108 \pm 25.1$ & $86.7 \pm 23.5$ \\
\hline $\mathrm{U} * 7-\mathrm{yr}$ & $63.9 \pm 35.2$ & $30.9 \pm 26.7$ & $164.9 \pm 53.4$ & $92.4 \pm 33.6$ & $18.9 \pm 6.9$ & $16.5 \pm 5.6$ & $109 \pm 25.2$ & $88.5 \pm 24.5$ \\
\hline Grand Mean & $79.9 \pm 55.6$ & $57.8 \pm 55.7$ & $187 \pm 78.9$ & $127 \pm 64.4$ & $27.1 \pm 16.4$ & $23.5 \pm 14.9$ & $126 \pm 33.7$ & $102 \pm 28.6$ \\
\hline & \multicolumn{8}{|c|}{$\operatorname{Pr}>\mathbf{F}$} \\
\hline Block & 0.0777 & 0.1629 & 0.0025 & 0.0010 & $<.0001$ & $<.0001$ & 0.0005 & 0.0048 \\
\hline Composted Manure & $<.0001$ & $<.0001$ & $<.0001$ & $<.0001$ & $<.0001$ & $<.0001$ & $<.0001$ & $<.0001$ \\
\hline Rotation Cycle & 0.0933 & $<.0001$ & 0.8577 & 0.1052 & 0.0599 & 0.0141 & 0.9726 & 0.0603 \\
\hline Manure* Rotation & $<.0001$ & $<.0001$ & 0.0009 & 0.0065 & 0.0016 & 0.0004 & 0.8253 & 0.0303 \\
\hline
\end{tabular}

$*$ Different letters within a column indicate significant difference at $\alpha=0.1$ within factor. Values following the \pm symbol are the standard deviation.

$\mathrm{M}=$ Manured plots; $\mathrm{U}=$ Unmanured plots. 
Table 11. Main effects of manure and rotation (4-yr and 7-yr) on stratified 2013 soil test calcium (STCa) and soil test magnesium (STMg) under the first (corn) and last (kale) crop component of the rotation.

\begin{tabular}{|c|c|c|c|c|c|c|c|c|}
\hline \multirow[t]{3}{*}{2013} & \multicolumn{4}{|c|}{ "Corn } & \multicolumn{4}{|c|}{ Kale } \\
\hline & \multicolumn{2}{|c|}{$\mathrm{STCa}(\mathrm{mg} / \mathrm{kg})$} & \multicolumn{2}{|c|}{ STMg $(\mathrm{mg} / \mathrm{kg})$} & \multicolumn{2}{|c|}{$\mathrm{STCa}(\mathrm{mg} / \mathrm{kg})$} & \multicolumn{2}{|c|}{$\mathrm{STMg}(\mathrm{mg} / \mathrm{kg})$} \\
\hline & $0-5 \mathrm{~cm}$ & $5-10 \mathrm{~cm}$ & $0-5 \mathrm{~cm}$ & $5-10 \mathrm{~cm}$ & $0-5 \mathrm{~cm}$ & $5-10 \mathrm{~cm}$ & $0-5 \mathrm{~cm}$ & $5-10 \mathrm{~cm}$ \\
\hline \multicolumn{9}{|l|}{ Composted Manure } \\
\hline $\mathrm{M}$ & $2292^{\mathrm{a}} \pm 460$ & $2268^{\mathrm{a}} \pm 559$ & $178.0^{\mathrm{a}} \pm 36$ & $154.9^{\mathrm{a}} \pm 34$ & $1849^{a} \pm 512$ & $1843^{\mathrm{a}} \pm 543$ & $147^{\mathrm{a}} \pm 30.3$ & $140^{\mathrm{a}} \pm 28.4$ \\
\hline $\mathrm{U}$ & $1585^{b} \pm 668$ & $1519^{\mathrm{b}} \pm 630$ & $133.5^{\mathrm{b}} \pm 40.2$ & $107.7^{\mathrm{b}} \pm 24.9$ & $1608^{\mathrm{b}} \pm 542$ & $1671^{\mathrm{a}} \pm 659$ & $141^{\mathrm{a}} \pm 47.2$ & $132^{\mathrm{a}} \pm 50.1$ \\
\hline \multicolumn{9}{|l|}{ Rotation Cycle } \\
\hline $4-y r$ & $1938.7^{\mathrm{a}} \pm 843$ & $2016.1^{\mathrm{a}} \pm 802$ & $137^{\mathrm{b}} \pm 44.2$ & $132.2^{\mathrm{a}} \pm 41.7$ & $1707^{\mathrm{a}} \pm 483$ & $1737^{\mathrm{a}} \pm 531$ & $135^{\mathrm{b}} \pm 38.7$ & $130^{\mathrm{a}} \pm 40.8$ \\
\hline $7-y r$ & $1938.4^{\mathrm{a}} \pm 454$ & $1770.4^{b} \pm 569$ & $174.5^{\mathrm{a}} \pm 35$ & $130.4^{\mathrm{a}} \pm 34.5$ & $1750^{\mathrm{a}} \pm 593$ & $1777^{\mathrm{a}} \pm 680$ & $153^{\mathrm{a}} \pm 39$ & $143^{\mathrm{a}} \pm 40$ \\
\hline \multicolumn{9}{|l|}{ Manure*Rotation } \\
\hline$M * 4-y r$ & $2442 \pm 455.9$ & $2493 \pm 460$ & $165.2 \pm 34.6$ & $161 \pm 30.3$ & $1887 \pm 549$ & $1915 \pm 624$ & $152 \pm 31$ & $149.2 \pm 29.2$ \\
\hline $\mathrm{M} * 7-\mathrm{yr}$ & $2142 \pm 428.0$ & $2043 \pm 572$ & $190.8 \pm 33.2$ & $149 \pm 37.6$ & $1811 \pm 488$ & $1770 \pm 460$ & $143 \pm 30$ & $130.9 \pm 25.2$ \\
\hline $\mathrm{U}^{* 4-\mathrm{yr}}$ & $1436 \pm 849.7$ & $1540 \pm 798$ & $108.7 \pm 33.7$ & $103 \pm 30.2$ & $1527 \pm 337$ & $1559 \pm 356$ & $118 \pm 39$ & $110.3 \pm 42.1$ \\
\hline $\mathrm{U} * 7-\mathrm{yr}$ & $1735 \pm 393.7$ & $1498 \pm 429$ & $158.3 \pm 29.9$ & $112 \pm 18.1$ & $1688 \pm 695$ & $1783 \pm 864$ & $163 \pm 44$ & $154.1 \pm 49.0$ \\
\hline Grand Mean & $1939 \pm 671$ & $1893 \pm 701$ & $155.8 \pm 43.9$ & $131 \pm 38.0$ & $1728 \pm 537$ & $1757 \pm 605$ & $144 \pm 39.4$ & $136 \pm 40.6$ \\
\hline & \multicolumn{8}{|c|}{ Pr $>\mathbf{F}$} \\
\hline Block & $<.0001$ & $<.0001$ & 0.0107 & 0.0022 & $<.0001$ & $<.0001$ & $<.0001$ & 0.0003 \\
\hline Composted Manure & $<.0001$ & $<.0001$ & $<.0001$ & $<.0001$ & 0.0170 & 0.1599 & 0.3994 & 0.3572 \\
\hline Rotation Cycle & 0.9982 & 0.0441 & $<.0001$ & 0.8059 & 0.6637 & 0.7434 & 0.0266 & 0.1393 \\
\hline Manure* Rotation & 0.0162 & 0.0925 & 0.1381 & 0.1443 & 0.2310 & 0.1311 & 0.0011 & 0.0006 \\
\hline
\end{tabular}

*Different letters within a column indicate significant difference at $\alpha=0.1$ within factor. Values following the \pm symbol are the standard deviation. $\mathrm{M}=$ Manured plots; $\mathrm{U}=$ Unmanured plots. 
Table 12. Main effects of manure and rotation (4-yr and 7-yr) on 2013 stratified soil test zinc (STZn) and total nitrogen (TotN) under the first (corn) and last (kale) crop component of the rotation.

\begin{tabular}{|c|c|c|c|c|c|c|c|c|}
\hline \multirow[t]{3}{*}{2013} & \multicolumn{4}{|c|}{ Corn } & \multicolumn{4}{|c|}{ Kale } \\
\hline & \multicolumn{2}{|c|}{ STZn $(\mathrm{mg} / \mathrm{kg})$} & \multicolumn{2}{|c|}{ TotN $(\mathrm{g} / \mathrm{kg})$} & \multicolumn{2}{|c|}{ STZn $(\mathrm{mg} / \mathrm{kg})$} & \multicolumn{2}{|c|}{ TotN $(\mathrm{g} / \mathrm{kg})$} \\
\hline & $0-5 \mathrm{~cm}$ & $5-10 \mathrm{~cm}$ & $0-5 \mathrm{~cm}$ & $5-10 \mathrm{~cm}$ & $0-5 \mathrm{~cm}$ & $5-10 \mathrm{~cm}$ & $0-5 \mathrm{~cm}$ & $5-10 \mathrm{~cm}$ \\
\hline \multicolumn{9}{|l|}{ Composted Manure } \\
\hline $\mathrm{M}$ & $6.6^{\mathrm{a}} \pm 1.7$ & $5.4^{\mathrm{a}} \pm 2.2$ & $3.0^{\mathrm{a}} \pm 0.4$ & $2.4^{\mathrm{a}} \pm 0.5$ & $3.8^{\mathrm{a}} \pm 1.3$ & $3.5^{\mathrm{a}} \pm 1.4$ & $2.3^{\mathrm{a}} \pm 0.3$ & $2.1^{\mathrm{a}} \pm 0.3^{3}$ \\
\hline $\mathrm{U}$ & $4.3^{\mathrm{b}} \pm 4.4$ & $3.3^{\mathrm{b}} \pm 4.0$ & $2.1^{\mathrm{b}} \pm 0.6$ & $1.5^{\mathrm{b}} \pm 0.4$ & $2.8^{\mathrm{b}} \pm 1.1$ & $2.7^{\mathrm{b}} \pm 1.1$ & $1.9^{\mathrm{a}} \pm 0.2$ & $1.8^{\mathrm{b}} \pm 0.3$ \\
\hline \multicolumn{9}{|l|}{ Rotation Cycle } \\
\hline $4-y r$ & $4.9^{\mathrm{a}} \pm 3.2$ & $4.6^{\mathrm{a}} \pm 3.3$ & $2.3^{\mathrm{b}} \pm 0.8$ & $2.0^{\mathrm{a}} \pm 0.8$ & $3.3^{\mathrm{a}} \pm 1.5$ & $3.1^{\mathrm{a}} \pm 1.6$ & $2.0^{\mathrm{b}} \pm 0.3$ & $1.9^{\mathrm{a}} \pm 0.4$ \\
\hline $7-y r$ & $6.1^{\mathrm{a}} \pm 3.7$ & $4.1^{\mathrm{a}} \pm 3.6$ & $2.8^{\mathrm{a}} \pm 0.4$ & $1.9^{\mathrm{a}} \pm 0.4$ & $3.3^{\mathrm{a}} \pm 1.0$ & $3.0^{\mathrm{a}} \pm 1.0$ & $2.2^{\mathrm{a}} \pm 0.3$ & $2.0^{\mathrm{a}} \pm 0.3$ \\
\hline \multicolumn{9}{|l|}{ Manure*Rotation } \\
\hline $\mathrm{M} * 4-\mathrm{yr}$ & $7.5 \pm 1.7$ & $7.0 \pm 1.9$ & $3.1 \pm 0.4$ & $2.6 \pm 0.3$ & $4.2 \pm 1.7$ & $4.0 \pm 1.8$ & $2.3 \pm 0.3$ & $2.1 \pm 0.3$ \\
\hline $\mathrm{M} * 7-\mathrm{yr}$ & $5.7 \pm 1.2$ & $3.8 \pm 1.2$ & $3.0 \pm 0.4$ & $2.1 \pm 0.4$ & $3.3 \pm 0.6$ & $2.9 \pm 0.7$ & $2.3 \pm 0.3$ & $2.1 \pm 0.3$ \\
\hline $\mathrm{U} * 4-\mathrm{yr}$ & $2.2 \pm 1.9$ & $2.2 \pm 2.5$ & $1.6 \pm 0.3$ & $1.3 \pm 0.4$ & $2.4 \pm 0.6$ & $2.2 \pm 0.6$ & $1.8 \pm 0.2$ & $1.7 \pm 0.2$ \\
\hline $\mathrm{U} * 7-\mathrm{yr}$ & $6.4 \pm 5.2$ & $4.4 \pm 5.0$ & $2.6 \pm 0.4$ & $1.8 \pm 0.4$ & $3.2 \pm 1.4$ & $3.1 \pm 1.3$ & $2.0 \pm 0.3$ & $1.9 \pm 0.3$ \\
\hline Grand Mean & $5.45 \pm 3.5$ & $4.4 \pm 3.4$ & $2.6 \pm 0.7$ & $1.9 \pm 3.5$ & $3.3 \pm 1.3$ & $3.1 \pm 1.3$ & $2.1 \pm 0.3$ & $1.9 \pm 0.3$ \\
\hline & \multicolumn{8}{|c|}{ Pr $>\mathbf{F}$} \\
\hline Block & 0.1591 & 0.1365 & 0.1902 & 0.0634 & 0.0310 & 0.1616 & 0.0004 & 0.0151 \\
\hline Composted Manure & 0.0033 & 0.0078 & $<.0001$ & $<.0001$ & 0.0018 & 0.0110 & $<.0001$ & $<.0001$ \\
\hline Rotation Cycle & 0.1173 & 0.5308 & $<.0001$ & 0.8414 & 0.8579 & 0.7035 & 0.0313 & 0.1416 \\
\hline Manure* Rotation & 0.0002 & 0.0010 & $<.0001$ & $<.0001$ & 0.0045 & 0.0028 & 0.3037 & 0.0207 \\
\hline
\end{tabular}

$*$ Different letters within a column indicate significant difference at $\alpha=0.1$ within factor. Values following the \pm symbol are the standard deviation.

$\mathrm{M}=$ Manured plots; U=Unmanured plots. 
Table 14. Effect of the 2013 manure and rotation treatments on cowpea and weed biomass.

\begin{tabular}{|c|c|c|c|}
\hline Variables & Cowpea Biomass & $\begin{array}{l}\text { Weed Biomass } \\
\mathrm{Mg} \mathrm{ha}^{-1}\end{array}$ & Total Biomass \\
\hline \multicolumn{4}{|l|}{ Manure } \\
\hline M & $3.21^{\mathrm{a}} \pm 1.15$ & $5.84^{\mathrm{a}} \pm 2.44$ & $9.05^{\mathrm{a}} \pm 2.44$ \\
\hline $\mathrm{U}$ & $1.57^{\mathrm{b}} \pm 1.02$ & $3.66^{\mathrm{a}} \pm 1.31$ & $4.97^{b} \pm 1.83$ \\
\hline \multicolumn{4}{|l|}{ Rotation } \\
\hline $4-y r$ & $2.91^{\mathrm{a}} \pm 1.36$ & $4.25^{\mathrm{a}} \pm 1.36$ & $7.16^{\mathrm{a}} \pm 2.57$ \\
\hline 7-yr & $1.93^{\mathrm{a}} \pm 1.25$ & $5.25^{\mathrm{a}} \pm 2.84$ & $6.86^{\mathrm{a}} \pm 3.56$ \\
\hline \multicolumn{4}{|l|}{ Manure*Rotation } \\
\hline $\mathrm{M}^{* 4-\mathrm{yr}}$ & $3.70 \pm 1.34$ & $4.93 \pm 1.02$ & $8.63 \pm 2.14$ \\
\hline $\mathrm{M}^{* 7-\mathrm{yr}}$ & $2.71 \pm 0.89$ & $6.75 \pm 3.37$ & $9.47 \pm 3.13$ \\
\hline $\mathrm{U}^{* 4-\mathrm{yr}}$ & $2.12 \pm 0.96$ & $3.57 \pm 1.48$ & $5.69 \pm 2.34$ \\
\hline $\mathrm{U} * 7-\mathrm{yr}$ & $0.75 \pm 0.34$ & $3.75 \pm 1.43$ & $4.25 \pm 1.17$ \\
\hline Grand Mean & $2.46 \pm 1.35$ & $\begin{array}{l}4.75 \pm 2.19 \\
\mathbf{P r}>\mathbf{F}\end{array}$ & $7.01 \pm 2.96$ \\
\hline Block & 0.7730 & 0.7352 & 0.9061 \\
\hline Manure & 0.0511 & 0.1418 & 0.0355 \\
\hline Rotation & 0.1487 & 0.4702 & 0.8483 \\
\hline Manure*Rotation & 0.7665 & 0.5479 & 0.4808 \\
\hline
\end{tabular}

*Different letters within a column indicate significant difference at $\alpha=0.1$ within factor. Values following the \pm symbol are the standard deviation. $\mathrm{M}=$ Manured plots; $\mathrm{U}=$ Unmanured plots.

\section{Within-Rotation Effect of Manure and Crop on Physical and Chemical Quality}

In 2014, soil property behavior was similar to that measured in 2013, although the magnitude of these properties differed slightly. In the next section, 2014 soil physical properties bulk density (BD), dry geometric mean diameter aggregation (DA-GMD), wet geometric mean diameter aggregation (WA-GMD), and soil organic matter at $0-10 \mathrm{~cm}$ depth (SOM) will be discussed within the 4-yr and 7-yr rotations (Table 15). Stratified bioavailable nutrients discussed for the depths $0-5$ and $5-10 \mathrm{~cm}$ are $\mathrm{pH}$, soil organic matter (SOM), soil test phosphorus (STP), soils test potassium (STK), soil test calcium (STCa), soil test magnesium (STMg), soil test zinc (STZn), and total nitrogen (TotN) (Tables 17, 18, 19, and 20).

\section{Manure effect within rotation type (4-yr and 7-yr)}

2014 surface bulk density values were statistically significantly affected by composted manure addition independent of rotation type. Plots receiving composted manure exhibited 
significantly lower bulk density (Table 15). Dry aggregate stability (DA-GMD) values were not affected by addition of manure in either rotation. Wet aggregate stability (WA-GMD) values were not significantly affected by addition of manure in 4-yr plots, but were significantly larger in manured plots in the 7-yr rotation (Table 15). As was found in 2013, 2014 SOM values were significantly affected by composted manure addition. In both rotations, plots receiving composted manure exhibited significantly higher SOM than plots receiving no composted manure.

In the 4 and 7-yr rotation cycles, $\mathrm{pH}$ and stratified SOM were both significantly affected by composted manure addition at all depths (Table 16). In all cases, soil $\mathrm{pH}$ and SOM were higher in manured plots than in unmanured plots. As was found for the year 2013, 2014 Soil test phosphorus values (STP), in 4-yr and 7-yr plots were significantly affected by composted manure addition at all depths. Soil test phosphorus was higher in manured plots than in unmanured plots. For the 4-yr and 7-yr rotation plots, STK was statistically significantly higher in manured plots than in unmanured plots. Soil test calcium (STCa) and soil test magnesium (STMg) between $0-10 \mathrm{~cm}$ behaved very similarly to $\mathrm{pH}$ and SOM. As measured in 4-yr and 7-yr plots, STCa values were significantly affected by composted manure addition at all depths (Table 19). Soil test calcium and STMg were higher in manured plots than in unmanured plots. Soil test Zinc and TotN values from $0-10 \mathrm{~cm}$ were statistically affected by manure application for both rotations (Table 19). In all cases, the nutrients were significantly higher in manured plots than in unmanured plots.

\section{Crop effect within rotation type (4-yr and 7-yr).}

A significant effect of crop was observed on bulk density regardless of rotation cycle (Table 15). Similarly to the year 2013, in 2014 a significant effect of crop was observed on DAGMD in both the 4-yr and 7-yr rotation cycles. Corn plots showed higher dry GMD than kale plots (Table 15). Wet GMD was significantly higher in the 4-year rotation kale than in the corn plots. No significant effect of crop was observed in the 7-year plots. 2014 SOM values were significantly affected by crop (corn or kale) in both the 4-yr and the 7-yr rotation cycle (Table 15). Corn plots in the 7-yr rotation exhibited statistically significantly higher SOM than kale 
plots. However kale plots had significantly higher SOM values than corn plots in the 4-yr rotation (Table 15$)$.

A significant effect of crop was found only at the $5-10 \mathrm{~cm}$ depth for $\mathrm{pH}$. In this case, soil $\mathrm{pH}$ values were higher in kale plots than in corn plots. No significant effect of crop was found on $\mathrm{pH}$ in the 7-yr rotation. Stratified soil organic matter (SOM) was significantly higher in kale plots than in corn plots in the 4-yr rotation, but in the 7-yr rotation, the opposite was true: SOM values in corn plots were significantly higher than in kale plots (Table 16). Soil test potassium was significantly higher in 4-yr kale plots than in 4-yr corn plots, but in the 7-yr rotation STP was significantly higher in corn plots (Table 17). Similarly to 2013 results, a significant effect of first or last crop in the rotation was also found at all depths regardless of rotation. Soil test potassium (STK) was higher in corn plots than in kale plots in both rotations (Table 17). An effect of crop was observed on STCa, but not on STMg. In 4-yr plots, STCa values were significantly higher in kale plots than in corn plots, but in the 7-yr rotation STCa values were higher in corn plots than in kale plots. A significant effect of crop was also observed on both STZn and TotN. In the 4-yr rotation, these nutrient values were higher in kale plots than in corn plots. In the 7-yr rotation STZn and TotN were significantly higher in corn plots than in kale (Table 19).

\section{Interactions between manure and crop within rotation type (4-yr and 7-yr).}

A significant interaction was observed between manure and crop on BD in the 4-yr rotation: manure corn and kale had similar BDs, however when the plots were manured, corn plots experienced a significant decrease in BD as compared to kale plots. This interaction was not observed for the 7-yr plots. An interaction was observed for DA-GMD between manure and crop in both rotations. A significant effect of block was observed in 7-yr plots for WA-GMD, but no interaction between manure and crop was observed. An interaction between manure and crop in the 4-yr plots was observed on SOM values, but not in 7-yr plots.

An interaction was observed for $\mathrm{pH}$ between manure and crop at all depths in 7-yr plots, and for stratified SOM in 4-yr plots at all depths. Interactions were observed between manure 
and crop at all depths for STP, regardless of rotation. Interactions were observed for STK between manure and crop in 7-yr plots at the 5-10cm depth, and in $4-y r$ plots at $0-5 \mathrm{~cm}$ and 5-10cm depths. A significant effect of block was observed on STCa and STMg in both rotations at all depths. No interaction was observed between manure and crop. An interaction was found between manure and crop on measured zinc and nitrogen; at all depths unmanured corn and kale plots had a similar TotN and STZn, but significant differences were observed when the corn and kale plots were manured. 
Table 15. Within-rotations (4-yr and 7-yr) main effects of manure and crop on 2014 soil physical quality indicators

\section{Rotation 4-yr Rotation 7-yr}

2014 Variables

$\mathrm{BD}$
$\mathrm{Mg} / \mathrm{m}^{3}$

DA-GMD

WA-GMD

\section{SOM}

$\mathrm{BD}$

DA-GMD

WA-GMD $\mathrm{mm}$

SOM

Manure

$\begin{array}{lll}\text { M } & 1.20^{\mathrm{b}} \pm 0.10 \quad 2.4^{\mathrm{a}} \pm 0.3\end{array}$

$4.5^{\mathrm{a}} \pm 0.6 \quad 4.2^{\mathrm{a}} \pm 3.1$

$1.10^{\mathrm{b}} \pm 0.10$

$2.3^{\mathrm{a}} \pm 0.2$

$5.1^{\mathrm{a}} \pm 0.6$

$4.3^{\mathrm{a}} \pm 1.5$

U $\quad 1.30^{\mathrm{a}} \pm 0.10 \quad 2.3^{\mathrm{a}} \pm 0.3$

$4.3^{\mathrm{a}} \pm 1.0$

$1.30^{\mathrm{a}} \pm 0.70$

$2.3^{\mathrm{a}} \pm 0.2$

$3.9^{\mathrm{b}} \pm 1.3$

$3.1^{\mathrm{b}} \pm 0.8$

Crop

C $\quad 1.30^{\mathrm{a}} \pm 0.10$

$2.6^{\mathrm{a}} \pm 0.2$

$4.9^{\mathrm{a}} \pm 0.9 \quad 3.9^{\mathrm{a}} \pm 0.9$

$1.20^{\mathrm{a}} \pm 0.70$

$2.4^{\mathrm{a}} \pm 0.2$

$2.2^{\mathrm{b}} \pm 0.2$

$4.6^{\mathrm{a}} \pm 1.0$

$3.9^{\mathrm{a}} \pm 1.2$

K $\quad 1.20^{\mathrm{b}} \pm 0.10$

$2.1^{\mathrm{b}} \pm 0.3$

$3.8^{\mathrm{b}} \pm 0.7$

$3.1^{\mathrm{b}} \pm 1.4$

$1.20^{\mathrm{a}} \pm 0.10$

$4.4^{\mathrm{a}} \pm 1.0$

$3.5^{\mathrm{b}} \pm 1.1$

Manure*Crop

$\begin{array}{rr}\mathrm{C}^{*} \mathrm{M} & 1.20 \pm 0.10 \\ \mathrm{~K} * \mathrm{M} & 1.10 \pm 0.10 \\ \mathrm{C} * \mathrm{U} & 1.30 \pm 0.10 \\ \mathrm{~K} * \mathrm{U} & 1.30 \pm 0.10 \\ & \\ \text { Grand Mean } & 1.20 \pm 0.10\end{array}$

$\begin{array}{lll}2.5 \pm 0.2 & 3.9 \pm 0.8 & 3.5 \pm 1.2 \\ 2.2 \pm 0.3 & 5.0 \pm 0.4 & 4.9 \pm 1.9 \\ 2.6 \pm 0.2 & 3.7 \pm 0.9 & 2.6 \pm 0.6 \\ 2.0 \pm 0.3 & 4.8 \pm 1.0 & 2.9 \pm 0.9 \\ 2.3 \pm 0.3 & 4.4 \pm 0.8 & 3.5 \pm 1.2\end{array}$

$1.10 \pm 0.10$
$1.10 \pm 0.10$
$1.30 \pm 0.40$
$1.20 \pm 0.10$
$1.20 \pm 0.09$

$\begin{array}{lll}2.4 \pm 0.2 & 5.0 \pm 0.8 & 4.6 \pm 1.6 \\ 2.3 \pm 0.1 & 5.2 \pm 0.4 & 4.0 \pm 1.5 \\ 2.5 \pm 0.2 & 4.2 \pm 1.1 & 3.2 \pm 0.8 \\ 2.1 \pm 0.2 & 3.7 \pm 1.5 & 2.9 \pm 0.8 \\ & & \\ 2.3 \pm 0.2 & 4.5 \pm 0.5 & 3.7 \pm 1.2\end{array}$

\begin{tabular}{lllll} 
& \multicolumn{4}{c}{ Pr>F } \\
Block & $<.0001$ & 0.0007 & 0.5892 & $<.0001$ \\
Manure & $<.0001$ & 0.1638 & 0.4049 & $<.0001$ \\
Crop & 0.0031 & $<.0001$ & $<.0001$ & $<.0001$ \\
Manure*Crop & 0.0007 & 0.0146 & 0.8611 & 0.0021 \\
\hline \hline
\end{tabular}

*Different letters within a column indicate significant difference at $\alpha=0.1$ within factor. Values following the \pm symbol are the standard deviation.

$\mathrm{BD}=$ Bulk Density; DA-GMD=Dry aggregate geometric mean diameter; WA-GMD=Wet aggregate geometric mean diameter; SOM (0-10cm)=Soil organic matter; $\mathrm{M}=$ Manured plots; $\mathrm{U}=\mathrm{Unmanured}$ plots; $\mathrm{C}=\mathrm{Corn}$; $\mathrm{K}=$ Kale. 
Table 16. Within-rotations (4-yr and 7-yr) main effects of manure and crop on 2014 stratified soil $\mathrm{pH}(\mathrm{KCl})$ and soil organic matter (SOM).

\begin{tabular}{|c|c|c|c|c|c|c|c|c|}
\hline \multirow[t]{3}{*}{2014} & \multicolumn{4}{|c|}{ "Rotation 4-yr } & \multicolumn{4}{|c|}{ "Rotation 7-yr } \\
\hline & \multicolumn{2}{|c|}{$\mathrm{pH}(\mathrm{KCL})$} & \multicolumn{2}{|c|}{$\operatorname{SOM}(\%)$} & \multicolumn{2}{|c|}{$\mathrm{pH}(\mathrm{KCl})$} & \multicolumn{2}{|c|}{$\operatorname{SOM}(\%)$} \\
\hline & $0-5 \mathrm{~cm}$ & $5-10 \mathrm{~cm}$ & $0-5 \mathrm{~cm}$ & $5-10 \mathrm{~cm}$ & $0-5 \mathrm{~cm}$ & $5-10 \mathrm{~cm}$ & $0-5 \mathrm{~cm}$ & $5-10 \mathrm{~cm}$ \\
\hline \multicolumn{9}{|l|}{ Composted Manure } \\
\hline - & $7.2^{\mathrm{a}} \pm 0.2$ & $7.2^{\mathrm{a}} \pm 0.4$ & $5.6^{\mathrm{a}} \pm 1.0$ & $4.6^{\mathrm{a}} \pm 0.9$ & $7.1^{\mathrm{a}} \pm 0.2$ & $7.2^{\mathrm{a}} \pm 0.2$ & $5.8^{\mathrm{a}} \pm 0.9$ & $4.6^{\mathrm{a}} \pm 0.8$ \\
\hline $\mathrm{U}$ & $6.4^{\mathrm{b}} \pm 0.4$ & $6.4^{\mathrm{b}} \pm 0.3$ & $3.4^{\mathrm{b}} \pm 0.6$ & $2.9^{b} \pm 0.7$ & $6.3^{b} \pm 0.2$ & $6.2^{b} \pm 0.3$ & $3.7^{\mathrm{b}} \pm 0.6$ & $3.2^{\mathrm{b}} \pm 1.2$ \\
\hline \multicolumn{9}{|l|}{ Crop } \\
\hline $\mathrm{C}$ & $6.8^{\mathrm{a}} \pm 0.3$ & $6.7^{\mathrm{b}} \pm 0.4$ & $3.8^{\mathrm{b}} \pm 0.6$ & $3.3^{\mathrm{b}} \pm 0.5$ & $6.8^{\mathrm{a}} \pm 0.2$ & $6.7^{\mathrm{a}} \pm 0.3$ & $5.1^{\mathrm{a}} \pm 0.8$ & $4.1^{\mathrm{a}} \pm 0.6$ \\
\hline $\mathrm{K}$ & $6.8^{\mathrm{a}} \pm 0.3$ & $6.8^{\mathrm{a}} \pm 0.3$ & $5.1^{\mathrm{a}} \pm 1.0$ & $4.1^{\mathrm{a}} \pm 1.0$ & $6.6^{a} \pm 0.2$ & $6.6^{\mathrm{a}} \pm 0.2$ & $4.4^{\mathrm{b}} \pm 0.8$ & $3.6^{\mathrm{b}} \pm 1.5$ \\
\hline \multicolumn{9}{|l|}{ Manure*Crop } \\
\hline $\mathrm{C}^{*} \mathrm{M}$ & $7.1 \pm 0.2$ & $7.1 \pm 0.4$ & $4.5 \pm 0.9$ & $3.8 \pm 0.6$ & $7.3 \pm 0.2$ & $7.3 \pm 0.2$ & $6.2 \pm 0.9$ & $4.9 \pm 0.7$ \\
\hline $\mathrm{K}^{*} \mathrm{M}$ & $7.2 \pm 0.1$ & $7.2 \pm 0.3$ & $6.5 \pm 1.2$ & $5.3 \pm 1.2$ & $7.0 \pm 0.2$ & $7.0 \pm 0.2$ & $5.4 \pm 0.9$ & $4.2 \pm 0.8$ \\
\hline$C^{*} \mathrm{U}$ & $6.5 \pm 0.3$ & $6.3 \pm 0.4$ & $3.0 \pm 0.4$ & $2.5 \pm 0.5$ & $6.2 \pm 0.2$ & $6.2 \pm 0.3$ & $3.9 \pm 0.7$ & $3.3 \pm 0.5$ \\
\hline $\mathrm{K} * \mathrm{U}$ & $6.5 \pm 0.4$ & $6.4 \pm 0.2$ & $3.6 \pm 0.8$ & $2.9 \pm 0.9$ & $6.3 \pm 0.2$ & $6.2 \pm 0.2$ & $3.5 \pm 0.6$ & $3.0 \pm 0.6$ \\
\hline Grand Mean & $6.8 \pm 0.3$ & $6.8 \pm 3.3$ & $4.5 \pm 0.9$ & $3.7 \pm 0.8$ & $6.7 \pm 0.2$ & $6.7 \pm 0.2$ & $4.8 \pm 0.8$ & $3.9 \pm 0.9$ \\
\hline & \multicolumn{8}{|c|}{ Pr $>\mathbf{F}$} \\
\hline Block & 0.0110 & 0.0002 & $<.0001$ & $<.0001$ & 0.3480 & 0.9583 & $<.0001$ & 0.0015 \\
\hline Composted Manure & $<.0001$ & $<.0001$ & $<.0001$ & $<.0001$ & $<.0001$ & $<.0001$ & $<.0001$ & $<.0001$ \\
\hline Crop & 0.5530 & 0.0594 & $<.0001$ & $<.0001$ & 0.0434 & 0.2086 & 0.0002 & 0.0091 \\
\hline Manure*Crop & 0.5030 & 0.7736 & 0.0006 & $<.0001$ & 0.0018 & 0.0107 & 0.3986 & 0.3019 \\
\hline
\end{tabular}

*Different letters within a column indicate significant difference at $\alpha=0.1$ within factor. Values following the \pm symbol are the standard deviation.

$\mathrm{M}=$ Manured plots; $\mathrm{U}=$ Unmanured plots; $\mathrm{C}=\mathrm{Corn} ; \mathrm{K}=$ Kale. 
Table 17. Within-rotations (4-yr and 7-yr) main effects of manure and crop on 2014 stratified soil test phosphorus (STP) and soil test potassium (STK).

\begin{tabular}{|c|c|c|c|c|c|c|c|c|}
\hline \multirow[t]{3}{*}{2014} & \multicolumn{4}{|c|}{ Rotation 4-yr } & \multicolumn{4}{|c|}{ Rotation 7-yr } \\
\hline & \multicolumn{2}{|c|}{$\mathrm{STP}(\mathrm{mg} / \mathrm{kg})$} & \multicolumn{2}{|c|}{$\operatorname{STK}(\mathrm{mg} / \mathrm{kg})$} & \multicolumn{2}{|c|}{$\mathrm{STP}(\mathrm{mg} / \mathrm{kg})$} & \multicolumn{2}{|c|}{$\operatorname{STK}(\mathrm{mg} / \mathrm{kg})$} \\
\hline & $0-5 \mathrm{~cm}$ & $5-10 \mathrm{~cm}$ & $0-5 \mathrm{~cm}$ & $5-10 \mathrm{~cm}$ & $0-5 \mathrm{~cm}$ & $5-10 \mathrm{~cm}$ & $0-5 \mathrm{~cm}$ & $5-10 \mathrm{~cm}$ \\
\hline \multicolumn{9}{|l|}{ Composted Manure } \\
\hline 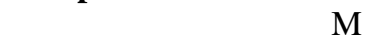 & $116^{\mathrm{a}} \pm 34.7$ & $92.4^{\mathrm{a}} \pm 38$ & $212^{\mathrm{a}} \pm 52$ & $160.6^{\mathrm{a}} \pm 44$ & $71.6^{\mathrm{a}} \pm 16.4$ & $45.1^{\mathrm{a}} \pm 16.0$ & $261.7^{\mathrm{a}} \pm 60.3$ & $164.8^{\mathrm{a}} \pm 44$ \\
\hline $\mathrm{U}$ & $14.3^{\mathrm{b}} \pm 5.7$ & $11.0^{\mathrm{b}} \pm 4.7$ & $68^{b} \pm 22$ & $83.2^{\mathrm{b}} \pm 23$ & $12.4^{\mathrm{b}} \pm 5.2$ & $9.6^{\mathrm{b}} \pm 4.2$ & $167.2^{\mathrm{b}} \pm 40.8$ & $96.0^{b} \pm 23$ \\
\hline \multicolumn{9}{|l|}{ Crop } \\
\hline $\mathrm{C}$ & $40.2^{\mathrm{b}} \pm 14$ & $30.0^{\mathrm{b}} \pm 13$ & $155^{\mathrm{a}} \pm 39$ & $136.3^{\mathrm{a}} \pm 81$ & $57.3^{\mathrm{a}} \pm 12$ & $36.0^{\mathrm{a}} \pm 12$ & $268.6^{\mathrm{a}} \pm 60$ & $181.3^{\mathrm{a}} \pm 46$ \\
\hline $\mathrm{K}$ & $90.2^{\mathrm{a}} \pm 26$ & $73.3^{\mathrm{a}} \pm 29$ & $125^{\mathrm{b}} \pm 35$ & $107.4^{\mathrm{b}} \pm 52$ & $28.3^{\mathrm{b}} \pm 9.4$ & $19.6^{\mathrm{b}} \pm 8.1$ & $163.7^{\mathrm{b}} \pm 41$ & $82.3^{\mathrm{b}} \pm 41$ \\
\hline \multicolumn{9}{|l|}{ Manure*Crop } \\
\hline $\mathrm{C} * \mathrm{M}$ & $72.9 \pm 25.1$ & $53.7 \pm 23.8$ & $239 \pm 46$ & $193.0 \pm 58.7$ & $99.9 \pm 18.0$ & $61.2 \pm 19.5$ & $311.7 \pm 68.0$ & $227.5 \pm 59.0$ \\
\hline $\mathrm{K} * \mathrm{M}$ & $59.2 \pm 44.2$ & $31.0 \pm 51.3$ & $185 \pm 58$ & $128.1 \pm 28.3$ & $43.3 \pm 14.8$ & $29.1 \pm 12.4$ & $211.7 \pm 52.5$ & $102.1 \pm 29.0$ \\
\hline $\mathrm{C}^{*} \mathrm{U}$ & $7.5 \pm 3.1$ & $6.3 \pm 2.7$ & $72 \pm 31.6$ & $79.57 \pm 22.4$ & $11.6 \pm 6.4$ & $9.1 \pm 4.5$ & $222.4 \pm 60.1$ & $131.9 \pm 33.7$ \\
\hline $\mathrm{K} * \mathrm{U}$ & $21.1 \pm 8.3$ & $15.7 \pm 6.7$ & $65 \pm 12.5$ & $86.7 \pm 23.5$ & $13.2 \pm 3.9$ & $10.1 \pm 3.8$ & $115.7 \pm 21.5$ & $62.5 \pm 12.3$ \\
\hline Grand Mean & $65.2 \pm 20.2$ & $51.7 \pm 21.1$ & $140 \pm 37$ & $121.9 \pm 33.2$ & $42.5 \pm 21.6$ & $27.7 \pm 10.1$ & $215.2 \pm 50.6$ & $131.0 \pm 33.5$ \\
\hline & \multicolumn{8}{|c|}{ Pr $>$ F } \\
\hline Block & 0.0255 & 0.0822 & 0.2213 & 0.2584 & 0.9517 & 0.5508 & 0.0354 & 0.0739 \\
\hline Composted Manure & $<.0001$ & $<.0001$ & $<.0001$ & $<.0001$ & $<.0001$ & $<.0001$ & $<.0001$ & $<.0001$ \\
\hline Crop & $<.0001$ & $<.0001$ & 0.2065 & 0.0055 & $<.0001$ & $<.0001$ & $<.0001$ & $<.0001$ \\
\hline Manure*Crop & $<.0001$ & $<.0001$ & 0.0823 & 0.0267 & $<.0001$ & $<.0001$ & 0.8539 & 0.0040 \\
\hline
\end{tabular}

*Different letters within a column indicate significant difference at $\alpha=0.1$ within factor. Values following the \pm symbol are the standard deviation.

$\mathrm{M}=$ Manured plots; $\mathrm{U}=$ Unmanured plots; $\mathrm{C}=\mathrm{Corn} ; \mathrm{K}=$ Kale. 
Table 18. Within-rotations (4-yr and 7-yr) main effects of manure and crop on 2014 stratified soil test calcium (STCa) and soil test magnesium (STMg).

\begin{tabular}{|c|c|c|c|c|c|c|c|c|}
\hline \multirow[t]{3}{*}{2014} & \multicolumn{4}{|c|}{ Rotation 4-yr } & \multicolumn{4}{|c|}{ Rotation 7-yr } \\
\hline & \multicolumn{2}{|c|}{$\mathrm{STCa}(\mathrm{mg} / \mathrm{kg})$} & \multicolumn{2}{|c|}{$\mathrm{STMg}(\mathrm{mg} / \mathrm{kg})$} & \multicolumn{2}{|c|}{$\mathrm{STCa}(\mathrm{mg} / \mathrm{kg})$} & \multicolumn{2}{|c|}{$\mathrm{STMg}(\mathrm{mg} / \mathrm{kg})$} \\
\hline & $0-5 \mathrm{~cm}$ & $5-10 \mathrm{~cm}$ & $0-5 \mathrm{~cm}$ & $5-10 \mathrm{~cm}$ & $0-5 \mathrm{~cm}$ & $5-10 \mathrm{~cm}$ & $0-5 \mathrm{~cm}$ & $5-10 \mathrm{~cm}$ \\
\hline \multicolumn{9}{|l|}{$\begin{array}{l}\text { Composted } \\
\text { Manure }\end{array}$} \\
\hline M & $2321^{\mathrm{a}} \pm 574$ & $2322^{a} \pm 648$ & $202^{\mathrm{a}} \pm 37.0$ & $188.2^{\mathrm{a}} \pm 36.4$ & $2403^{\mathrm{a}} \pm 299$ & $2298^{\mathrm{a}} \pm 381$ & $213.8^{\mathrm{a}} \pm 36.7$ & $192.2^{\mathrm{a}} \pm 42$ \\
\hline $\mathrm{U}$ & $1284^{b} \pm 345$ & $1340^{b} \pm 365$ & $114^{b} \pm 32.8$ & $111.1^{\mathrm{b}} \pm 42.7$ & $1358^{\mathrm{b}} \pm 359$ & $1346^{\mathrm{b}} \pm 346$ & $131.2^{b} \pm 42.4$ & $118.4^{b} \pm 43.7$ \\
\hline \multicolumn{9}{|l|}{ Crop } \\
\hline $\mathrm{C}$ & $1729^{b} \pm 514.3$ & $1778^{\mathrm{a}} \pm 543.7$ & $160.6^{\mathrm{a}} \pm 39.1$ & $149.1^{\mathrm{a}} \pm 40.0$ & $2120^{\mathrm{a}} \pm 380$ & $2029^{a} \pm 449$ & $173.4^{\mathrm{a}} \pm 42.5$ & $152.0^{\mathrm{a}} \pm 48.5$ \\
\hline $\mathrm{K}$ & $1876^{\mathrm{a}} \pm 404.5$ & $1885^{\mathrm{a}} \pm 469.5$ & $155.7^{\mathrm{a}} \pm 30.7$ & $150.1^{\mathrm{a}} \pm 39.1$ & $1666^{\mathrm{b}} \pm 378$ & $1638^{\mathrm{b}} \pm 277$ & $173.0^{\mathrm{a}} \pm 36.6$ & $159.7^{\mathrm{a}} \pm 37.3$ \\
\hline \multicolumn{9}{|l|}{ Manure*Crop } \\
\hline $\mathrm{C}^{*} \mathrm{M}$ & $2049 \pm 639.5$ & $2068 \pm 651.9$ & $204.8 \pm 37.3$ & $183.9 \pm 29.5$ & $2745 \pm 302$ & $2569 \pm 486$ & $209.3 \pm 34.1$ & $179.7 \pm 44.9$ \\
\hline $\mathrm{K} * \mathrm{M}$ & $2593 \pm 508.5$ & $2577 \pm 643.9$ & $199.3 \pm 36.6$ & $192.5 \pm 43.3$ & $2061 \pm 295$ & $2027 \pm 277$ & $218.3 \pm 39.2$ & $204.7 \pm 39.1$ \\
\hline $\mathrm{C} * \mathrm{U}$ & $1409 \pm 389.0$ & $1487 \pm 435.4$ & $116.4 \pm 40.9$ & $114.4 \pm 50.5$ & $1452 \pm 459$ & $1450 \pm 413$ & $135.0 \pm 50.8$ & $122.3 \pm 52.0$ \\
\hline $\mathrm{K} * \mathrm{U}$ & $1159 \pm 300.5$ & $1193 \pm 294.7$ & $112.1 \pm 24.7$ & $107.7 \pm 34.8$ & $1270 \pm 260$ & $1250 \pm 279$ & $127.7 \pm 33.9$ & $114.7 \pm 35.4$ \\
\hline Grand Mean & $1802 \pm 459.4$ & $1831 \pm 506.5$ & $158.2 \pm 34.9$ & $149.6 \pm 39.5$ & $1889 \pm 329$ & $1830 \pm 364$ & $173.2 \pm 42.9$ & $155.9 \pm 42.9$ \\
\hline & & & & $\operatorname{Pr}>\mathbf{F}$ & & & & \\
\hline Block & $<.0001$ & $<.0001$ & 0.0028 & 0.0193 & $<.0001$ & $<.0001$ & 0.0001 & 0.0009 \\
\hline Composted Manure & $<.0001$ & $<.0001$ & $<.0001$ & $<.0001$ & $<.0001$ & $<.0001$ & $<.0001$ & $<.0001$ \\
\hline Crop & 0.0434 & 0.1789 & 0.5597 & 0.9223 & $<.0001$ & $<.0001$ & 0.9002 & 0.3723 \\
\hline Manure*Crop & $<.0001$ & $<.0001$ & 0.9398 & 0.4423 & 0.0004 & 0.0406 & 0.3823 & 0.1176 \\
\hline
\end{tabular}

$*$ Different letters within a column indicate significant difference at $\alpha=0.1$ within factor. Values following the \pm symbol are the standard deviation.

$\mathrm{M}=$ Manured plots; $\mathrm{U}=$ Unmanured plots; $\mathrm{C}=\mathrm{Corn}$; $\mathrm{K}=$ Kale. 
Table 19. Within-rotations (4-yr and 7-yr) main effects of manure and crop on 2014 stratified soil test zinc (STZn) and total nitrogen (TotN).

\begin{tabular}{|c|c|c|c|c|c|c|c|c|}
\hline \multirow[t]{3}{*}{2014} & \multicolumn{4}{|c|}{ "Rotation 4-yr } & \multicolumn{4}{|c|}{ "Rotation 7-yr } \\
\hline & \multicolumn{2}{|c|}{ STZn $(\mathrm{mg} / \mathrm{kg})$} & \multicolumn{2}{|c|}{$\operatorname{Tot} \mathrm{N}(\mathrm{g} / \mathrm{kg})$} & \multicolumn{2}{|c|}{ STZn $(\mathrm{mg} / \mathrm{kg})$} & \multicolumn{2}{|c|}{$\operatorname{TotN}(\mathrm{g} / \mathrm{kg})$} \\
\hline & $0-5 \mathrm{~cm}$ & $5-10 \mathrm{~cm}$ & $0-5 \mathrm{~cm}$ & $5-10 \mathrm{~cm}$ & $0-5 \mathrm{~cm}$ & $5-10 \mathrm{~cm}$ & $0-5 \mathrm{~cm}$ & $5-10 \mathrm{~cm}$ \\
\hline \multicolumn{9}{|l|}{ Composted Manure } \\
\hline M & $9.2^{\mathrm{a}} \pm 4.6$ & $8.2^{\mathrm{a}} \pm 4.8$ & $2.9^{\mathrm{a}} \pm 0.5$ & $2.5^{\mathrm{a}} \pm 0.5$ & $6.9^{\mathrm{a}} \pm 2.0$ & $5.6^{\mathrm{a}} \pm 2.0$ & $3.1^{\mathrm{a}} \pm 0.4$ & $2.5^{\mathrm{a}} \pm 0.5$ \\
\hline $\mathrm{U}$ & $2.3^{\mathrm{b}} \pm 0.8$ & $2.0^{\mathrm{b}} \pm 0.7$ & $1.8^{\mathrm{b}} \pm 0.3$ & $1.6^{\mathrm{b}} \pm 0.4$ & $2.5^{\mathrm{b}} \pm 0.6$ & $2.2^{\mathrm{b}} \pm 0.5$ & $2.0^{\mathrm{b}} \pm 0.3$ & $1.7^{\mathrm{b}} \pm 0.2$ \\
\hline \multicolumn{9}{|l|}{ Crop } \\
\hline $\mathrm{C}$ & $4.3^{\mathrm{b}} \pm 1.5$ & $3.8^{\mathrm{b}} \pm 1.2$ & $2.1^{\mathrm{b}} \pm 0.3$ & $1.9^{\mathrm{b}} \pm 0.4$ & $5.5^{\mathrm{a}} \pm 1.5$ & $4.3^{\mathrm{a}} \pm 1.6$ & $2.8^{\mathrm{a}} \pm 0.3$ & $2.3^{\mathrm{a}} \pm 0.3$ \\
\hline $\mathrm{K}$ & $7.1^{\mathrm{a}} \pm 3.9$ & $6.4^{\mathrm{a}} \pm 4.3$ & $2.6^{\mathrm{a}} \pm 0.5$ & $2.1^{\mathrm{a}} \pm 0.5$ & $4.0^{\mathrm{b}} \pm 1.0$ & $3.5^{\mathrm{b}} \pm 1.0$ & $2.3^{\mathrm{b}} \pm 0.4$ & $2.0^{\mathrm{b}} \pm 0.3$ \\
\hline \multicolumn{9}{|l|}{ Manure*Crop } \\
\hline $\mathrm{C} * \mathrm{M}$ & $6.5 \pm 2.5$ & $5.6 \pm 2.0$ & $2.5 \pm 0.4$ & $2.2 \pm 0.3$ & $8.5 \pm 2.6$ & $6.5 \pm 2.8$ & $3.4 \pm 0.4$ & $2.8 \pm 0.5$ \\
\hline $\mathrm{K}^{*} \mathrm{M}$ & $11.8 \pm 6.6$ & $10.9 \pm 7.5$ & $3.3 \pm 0.5$ & $2.7 \pm 0.6$ & $5.3 \pm 1.3$ & $4.7 \pm 1.2$ & $2.8 \pm 0.4$ & $2.3 \pm 0.4$ \\
\hline $\mathrm{C} * \mathrm{U}$ & $2.2 \pm 0.4$ & $2.0 \pm 0.4$ & $1.7 \pm 0.1$ & $1.7 \pm 0.4$ & $2.3 \pm 0.4$ & $1.9 \pm 0.3$ & $2.0 \pm 0.2$ & $1.7 \pm 0.1$ \\
\hline $\mathrm{K} * \mathrm{U}$ & $2.4 \pm 1.1$ & $2.0 \pm 1.0$ & $1.9 \pm 0.4$ & $1.5 \pm 0.3$ & $2.7 \pm 0.7$ & $2.4 \pm 0.7$ & $1.9 \pm 0.3$ & $1.7 \pm 0.2$ \\
\hline Grand Mean & $5.7 \pm 2.7$ & $5.1 \pm 2.7$ & $2.4 \pm 0.4$ & $2.0 \pm 0.4$ & $4.7 \pm 1.3$ & $3.9 \pm 1.3$ & $2.5 \pm 0.3$ & $2.1 \pm 0.3$ \\
\hline & \multicolumn{8}{|c|}{$\operatorname{Pr}>\mathbf{F}$} \\
\hline Block & 0.0002 & 0.0004 & $<.0001$ & $<.0001$ & 0.0106 & 0.0408 & 0.0001 & 0.0168 \\
\hline Composted Manure & $<.0001$ & $<.0001$ & $<.0001$ & $<.0001$ & $<.0001$ & $<.0001$ & $<.0001$ & $<.0001$ \\
\hline Crop & 0.0010 & 0.0053 & $<.0001$ & 0.0162 & 0.0003 & 0.0735 & $<.0001$ & 0.0033 \\
\hline Manure*Crop & 0.0027 & 0.0047 & 0.0002 & 0.0002 & $<.0001$ & 0.0053 & 0.0024 & 0.0168 \\
\hline
\end{tabular}

*Different letters within a column indicate significant difference at $\alpha=0.1$ within factor. Values following the \pm symbol are the standard deviation.

$\mathrm{M}=$ Manured plots; $\mathrm{U}=$ Unmanured plots; $\mathrm{C}=$ Corn; $\mathrm{K}=$ Kale. 
2014 Between-Rotation Effect of Manure and Rotation on Physical and Chemical Quality, and Biomass

In 2014, soil property behavior was similar to that measured in 2013, although the magnitude of these properties differed slightly. In the next section, 2014 soil physical properties will be discussed between the 4-yr and 7-yr rotations: bulk density (BD), dry geometric mean diameter aggregation (DA-GMD), wet geometric mean diameter aggregation (WA-GMD), and soil organic matter at $0-10 \mathrm{~cm}$ depth (SOM) (Table 20).Stratified bioavailable nutrients discussed for the depths $0-5$ and $5-10 \mathrm{~cm}$ are $\mathrm{pH}$, soil organic matter (SOM), soil test phosphorus (STP), soils test potassium (STK), soil test calcium (STCa), soil test magnesium (STMg), soil test zinc (STZn), and total nitrogen (TotN) (Tables 21, 22, 23, and 24).

In 2014, corn rows were planted at a greater distance $(0.9-1.1 \mathrm{~m})$ than in $2013(0.75-$ $0.8 \mathrm{~m})$. Additionally, distance between plants in a row were measured to be highly variable (ranging from 0.12 to $0.30 \mathrm{~cm}$ ) and mostly toward the low end of this spectrum. This makes statistical analysis of this data inefficient for performing comparisons within 2014, and together with 2013 biomass data. Due to the previous experimental issues, the 2014 corn biomass data were presented on a per-plant basis, and no ANOVA was run on these data. In Table 25 the 2014 mean, standard deviation, and coefficient of variation per treatment for stalk + leaves, ear, kernel, and total cumulative biomass per corn plant are presented.

2014 cowpea biomass data were also incomplete, due to mismanagement of the "kale" plots before the pre-established sampling date. Biomass samples were not able to be gathered for the entire 7-yr treatment, as they were grazed by sheep earlier than expected, and the plant material was lost. Data available therefore may only be used to compare the manure treatment to the unmanured treatment within the 4-yr rotation.

\section{Manure effect between rotations, within first and last crop in the sequence.}

Similarly to the year 2013, in 2014 manured plots significantly decreased BD regardless of crop (Table 20). Dry aggregate stability values (DA-GMD) for 2014 were significantly larger in corn plots not receiving composted manure than those receiving composted manure, as shown 
below in Table 20. However, dry aggregate stability was significantly larger in manured kale plots than unmanured plots. There was significant effect of manure on WA-GMD regardless of crop. Wet aggregate stability GMD (WA-GMD) values were significantly larger in both corn and kale plots receiving composted manure than those not receiving composted manure (Table 20). This observation supports findings from 2013. Statistically significant effects of manure application were observed on SOM for the first (corn) and the last (kale) crop in the rotations. SOM values were higher in manured corn and kale plots (Table 20).

In 2014, the main effect of manure on soil $\mathrm{pH}$ and SOM was similar to the year 2013. pH and stratified SOM were higher in manured plots than in unmanured plots (Table 21). As for 2013 data, the nutrients $\mathrm{P}, \mathrm{K}, \mathrm{Ca}, \mathrm{Mg}, \mathrm{K}, \mathrm{Zn}$, and $\mathrm{N}$ were found to be significantly higher in manured plots than in unmanured plots (Tables 21, 22, 23, and 24).

Corn biomass results suggested that, regardless of rotation cycle, manured corn plot biomass was consistently higher per plant than unmanured plots (Table 25). Manure application did not appear to have an effect on cowpea biomass, which may be the consequence of kale plot mismanagement. However, similar to 2013, weeds are the main component of the total biomass (Table 26).

\section{Rotation type effect between rotations, within first and last crop in the sequence.}

The effect of rotation was observed on BD regardless of crop component: 4-yr rotation always exhibited significantly higher BD than the 7-yr rotation. In corn plots, DA-GMD was significantly higher in the 4-year rotation cycle, compared to the 7-year cycle corn plots. No significant effect of rotation cycle was observed on DA-GMD in kale plots (Table 20). There was a significant effect of rotation on WA-GMD regardless of crop. Although not significant, when corn was grown in the 4-yr rotation, WA-GMD was smaller than in corn plots in the 7-yr rotation. The opposite was observed for kale, although significant differences were observed. WA-GMD was smaller in the 7-yr rotation than in the 4-yr. A statistically significant effect of rotation was observed on SOM regardless of crop. Corn plots in the 7-yr cycle had higher SOM, while kale plots in the 4-yr cycle had significantly higher SOM than kale plots in the 7-yr cycle. 
Only in the kale plots was soil $\mathrm{pH}$ at all depths significantly affected by rotation. In these cases, $\mathrm{pH}$ was higher in the 4-yr than in the 7-yr rotation. Soil Organic Matter values were significantly higher in 7-yr corn plots than in 4-yr corn plots, but in kale plots the trend reversed; SOM values in 4-yr kale plots were higher than those in 7-yr kale plots. A significant effect of rotation was found on STP and STK, regardless of crop. Soil test phosphorus (STP) and STK were significantly higher in 7-yr corn plots than in 4-yr corn plots, but in kale STP and STK were significantly higher in the 4-yr rotation plots (Table 22). A significant effect of rotation on STCa was observed regardless of crop; in corn plots, values in the 7-yr rotation were significantly higher than those in the 4-yr rotation, while in kale plots values in the 4-yr plots were higher than those in the 7-yr plots. A significant effect of rotation was found on STMg only in kale plots at the $0-5 \mathrm{~cm}$ depth. In this case, STMg was significantly higher in 7-yr kale plots than in 4-yr kale plots (Table 23). There was a significant effect of rotation on STZn $(0-10 \mathrm{~cm})$ and TotN $(5-10 \mathrm{~cm})$ in corn and kale plots. In corn plots, STZn was significantly higher in 7-yr plots than in 4-yr plots, but only at the surface depth $(0-5 \mathrm{~cm})$. In kale, STZn values were significantly higher in the 4-yr rotation than in the 7-yr rotation (Table 24). Total nitrogen in corn plots was significantly higher in the 7-yr rotation, while in kale plots it was significantly higher in the 4-yr rotation.

Corn biomass results suggest that 7-yr rotation per-plant-biomass was always (when holding manure addition constant) higher than that of the 4-yr rotation. The effect of rotation cycle on 2014 cowpea biomass could not be established with the current biomass observations. It was not possible to relate the statistically significant effect of manure and/or rotation cycle on soil quality indicator variables (physical and chemical) to the resulting 2014 biomass production. The 2014 incomplete biomass information gathered in the field was not adequate to fulfill the study's objective to measure differences in biomass between first and last crop components of two rotation cycles subjected at two levels of composted manure.

\section{Interactions between manure and rotation, within first and last crop in the sequence.}

An interaction was observed on bulk density values between manure and rotation in corn plots on bulk density values; manure application was associated with less of a decrease in BD in 
4-yr rotation than in 7-yr rotation. An interaction was observed between manure and rotation in kale plots, but not for the corn plots. An interaction was observed between manure and rotation for $\mathrm{pH}$ and SOM at all depths in corn plots and for SOM in kale, however no interaction was observed for $\mathrm{pH}$ in kale. No significant effect of block was observed, except on STK values in corn plots at the $0-5 \mathrm{~cm}$ depth. An interaction was observed between manure and rotation at all depths for both nutrients in kale, and for both at the $0-5 \mathrm{~cm}$ depth in corn. A significant effect of block was observed for STCa in both crops at all depths. A high-magnitude interaction was found between manure and rotation for STCa values. No interaction was observed between manure and rotation for STMg. Manure by rotation interaction was observed for STZn $(0-5 \mathrm{~cm}$ in corn plots, and $0-10 \mathrm{~cm}$ in kale plots) and TotN (0-10 cm in corn and kale). 
Table 20. 2014 Main effects of manure and rotation (4-yr and 7-yr) on soil physical quality indicators under the first (corn) and last (kale) crop component of the rotation.

\begin{tabular}{|c|c|c|c|c|c|c|c|c|}
\hline \multirow[b]{2}{*}{2014 Variables } & \multicolumn{4}{|c|}{ Corn } & \multicolumn{4}{|c|}{ Kale } \\
\hline & $\begin{array}{c}\mathrm{BD} \\
\mathrm{Mg} / \mathrm{m}^{3}\end{array}$ & $\begin{array}{c}\text { DA-GMD } \\
\mathrm{mm}\end{array}$ & $\begin{array}{c}\text { WA-GMD } \\
\text { Mm }\end{array}$ & $\begin{array}{c}\text { SOM } \\
\% \\
\end{array}$ & $\begin{array}{c}\mathrm{BD} \\
\mathrm{Mg} / \mathrm{m}^{3}\end{array}$ & $\begin{array}{c}\text { DA-GMD } \\
\mathrm{mm}\end{array}$ & $\begin{array}{c}\text { WA-GMD } \\
\text { mm }\end{array}$ & $\begin{array}{c}\mathrm{SOM} \\
\%\end{array}$ \\
\hline \multicolumn{9}{|l|}{ Manure } \\
\hline M & $1.17^{\mathrm{b}} \pm 0.09$ & $2.4^{\mathrm{b}} \pm 0.2$ & $4.4^{\mathrm{a}} \pm 0.8$ & $4.1^{\mathrm{a}} \pm 1.5$ & $1.10^{\mathrm{b}} \pm 0.10$ & $2.2^{\mathrm{a}} \pm 0.2$ & $5.1^{\mathrm{a}} \pm 0.4$ & $4.5^{\mathrm{a}} \pm 1.7$ \\
\hline $\mathrm{U}$ & $1.30^{\mathrm{a}} \pm 0.07$ & $2.6^{\mathrm{a}} \pm 0.2$ & $4.0^{\mathrm{b}} \pm 1.0$ & $2.9^{\mathrm{b}} \pm 0.8$ & $1.30^{\mathrm{a}} \pm 0.07$ & $2.0^{\mathrm{b}} \pm 0.3$ & $4.3^{\mathrm{b}} \pm 1.3$ & $2.9^{\mathrm{b}} \pm 0.9$ \\
\hline \multicolumn{9}{|l|}{ Rotation Cycle } \\
\hline $4-y r$ & $1.30^{\mathrm{a}} \pm 0.10$ & $2.6^{\mathrm{a}} \pm 0.2$ & $3.8^{\mathrm{b}} \pm 0.9$ & $3.1^{\mathrm{b}} \pm 1.9$ & $1.19^{\mathrm{a}} \pm 0.10$ & $2.1^{\mathrm{a}} \pm 0.3$ & $4.9^{\mathrm{a}} \pm 0.7$ & $3.9^{\mathrm{a}} \pm 1.4$ \\
\hline $7-y r$ & $1.20^{\mathrm{b}} \pm 0.07$ & $2.4^{\mathrm{b}} \pm 0.2$ & $4.6^{\mathrm{a}} \pm 1.0$ & $3.9^{\mathrm{a}} \pm 1.2$ & $1.16^{\mathrm{b}} \pm 0.07$ & $2.2^{\mathrm{a}} \pm 0.2$ & $4.4^{\mathrm{b}} \pm 1.0$ & $3.5^{\mathrm{b}} \pm 1.1$ \\
\hline \multicolumn{9}{|l|}{ Manure*Rotation } \\
\hline $\mathrm{M}^{* 4-\mathrm{yr}}$ & $1.20 \pm 0.10$ & $2.5 \pm 0.2$ & $3.9 \pm 0.8$ & $3.5 \pm 1.2$ & $1.10 \pm 0.10$ & $2.2 \pm 0.3$ & $5.0 \pm 0.4$ & $4.9 \pm 1.9$ \\
\hline $\mathrm{M}^{* 7-y r}$ & $1.10 \pm 0.10$ & $2.4 \pm 0.2$ & $5.0 \pm 0.8$ & $4.6 \pm 1.6$ & $1.10 \pm 0.10$ & $2.3 \pm 0.1$ & $5.2 \pm 0.4$ & $4.0 \pm 1.5$ \\
\hline $\mathrm{U}^{* 4} 4-\mathrm{yr}$ & $1.30 \pm 0.10$ & $2.6 \pm 0.2$ & $3.7 \pm 0.9$ & $2.6 \pm 0.8$ & $1.30 \pm 0.10$ & $2.0 \pm 0.3$ & $4.8 \pm 1.0$ & $2.9 \pm 0.9$ \\
\hline $\mathrm{U} * 7-\mathrm{yr}$ & $1.30 \pm 0.04$ & $2.5 \pm 0.2$ & $4.2 \pm 1.1$ & $3.2 \pm 0.8$ & $1.20 \pm 0.04$ & $2.1 \pm 0.2$ & $3.7 \pm 1.5$ & $2.9 \pm 0.8$ \\
\hline Grand Mean & $1.20 \pm 0.09$ & $2.5 \pm 0.2$ & $4.2 \pm 0.9$ & $3.5 \pm 1.1$ & $1.20 \pm 0.09$ & $2.1 \pm 2.3$ & $4.7 \pm 0.8$ & $3.7 \pm 1.3$ \\
\hline & \multicolumn{4}{|c|}{$\operatorname{Pr}>\mathbf{F}$} & \multicolumn{4}{|c|}{ Pr $>\mathbf{F}$} \\
\hline Block & 0.2775 & 0.0814 & 0.0743 & 0.0207 & 0.0073 & 0.1352 & 0.0643 & $<.0001$ \\
\hline Manure & $<.0001$ & 0.0392 & 0.0486 & $<.0001$ & $<.0001$ & 0.0002 & 0.0008 & $<.0001$ \\
\hline Rotation & 0.0019 & 0.0485 & 0.0015 & $<.0001$ & 0.0661 & 0.2556 & 0.0409 & 0.0156 \\
\hline Manure*Rotation & 0.0022 & 0.3091 & 0.2778 & 0.1452 & 0.6016 & 0.9956 & 0.0044 & 0.0196 \\
\hline
\end{tabular}

*Different letters within a column indicate significant difference at $\alpha=0.1$ within factor. Values following the \pm symbol are the standard deviation.

$\mathrm{BD}=$ Bulk Density; DA-GMD=Dry aggregate geometric mean diameter; WA-GMD=Wet aggregate geometric mean diameter; $S O M(0-10 \mathrm{~cm})=$ Soil organic matter; $\mathrm{M}=$ Manured plots; $\mathrm{U}=$ Unmanured plots. 
Table 21. Main effects of manure and rotation (4-yr and 7-yr) on stratified 2014 stratified soil $\mathrm{pH}(\mathrm{KCl})$ and soil organic matter (SOM) under the first (corn) and last (kale) crop component of the rotation.

\begin{tabular}{|c|c|c|c|c|c|c|c|c|}
\hline \multirow[t]{3}{*}{2014} & \multicolumn{4}{|c|}{ Corn } & \multicolumn{4}{|c|}{ Kale } \\
\hline & \multicolumn{2}{|c|}{$\mathrm{pH}(\mathrm{KCL})$} & \multicolumn{2}{|c|}{$\operatorname{SOM}(\%)$} & \multicolumn{2}{|c|}{$\mathrm{pH}(\mathrm{KCl})$} & \multicolumn{2}{|c|}{$\operatorname{SOM}(\%)$} \\
\hline & $0-5 \mathrm{~cm}$ & $5-10 \mathrm{~cm}$ & $0-5 \mathrm{~cm}$ & $5-10 \mathrm{~cm}$ & $0-5 \mathrm{~cm}$ & $5-10 \mathrm{~cm}$ & $0-5 \mathrm{~cm}$ & $5-10 \mathrm{~cm}$ \\
\hline \multicolumn{9}{|l|}{ Composted Manure } \\
\hline 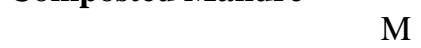 & $7.2^{\mathrm{a}} \pm 0.2$ & $7.2^{\mathrm{a}} \pm 0.2$ & $5.4^{\mathrm{a}} \pm 0.9$ & $4.3^{\mathrm{a}} \pm 0.6$ & $7.1^{\mathrm{a}} \pm 0.2$ & $7.1^{\mathrm{a}} \pm 0.2$ & $5.9^{\mathrm{a}} \pm 1.1$ & $4.8^{\mathrm{a}} \pm 1.0$ \\
\hline $\mathrm{U}$ & $6.3^{\mathrm{b}} \pm 0.3$ & $6.2^{\mathrm{b}} \pm 0.3$ & $3.5^{\mathrm{b}} \pm 0.6$ & $3.0^{\mathrm{b}} \pm 0.5$ & $6.3^{\mathrm{b}} \pm 0.3$ & $6.3^{\mathrm{b}} \pm 0.2$ & $3.6^{\mathrm{b}} \pm 0.8$ & $2.9^{b} \pm 0.8$ \\
\hline \multicolumn{9}{|l|}{ Rotation Cycle } \\
\hline $4-y r$ & $6.8^{\mathrm{a}} \pm 0.3$ & $6.7^{\mathrm{a}} \pm 0.3$ & $3.8^{\mathrm{b}} \pm 0.7$ & $3.3^{\mathrm{b}} \pm 0.5$ & $6.8^{\mathrm{a}} \pm 0.2$ & $6.8^{\mathrm{a}} \pm 0.2$ & $5.1^{\mathrm{a}} \pm 1.0$ & $4.1^{\mathrm{a}} \pm 1.0$ \\
\hline $7-y r$ & $6.8^{\mathrm{a}} \pm 0.2$ & $6.7^{\mathrm{a}} \pm 0.3$ & $5.1^{\mathrm{a}} \pm 0.8$ & $4.1^{\mathrm{a}} \pm 0.6$ & $6.6^{\mathrm{b}} \pm 0.2$ & $6.6^{\mathrm{b}} \pm 0.2$ & $4.4^{b} \pm 0.8$ & $3.6^{\mathrm{b}} \pm 0.7$ \\
\hline \multicolumn{9}{|l|}{ Manure*Rotation } \\
\hline $\mathrm{M}^{* 4-\mathrm{yr}}$ & $7.1 \pm 0.2$ & $7.1 \pm 0.3$ & $4.5 \pm 0.9$ & $3.8 \pm 0.6$ & $7.2 \pm 0.1$ & $7.2 \pm 0.2$ & $6.6 \pm 1.2$ & $5.3 \pm 1.2$ \\
\hline $\mathrm{M} * 7-\mathrm{yr}$ & $7.3 \pm 0.2$ & $7.3 \pm 0.2$ & $6.2 \pm 0.8$ & $4.9 \pm 0.8$ & $7.0 \pm 0.2$ & $7.0 \pm 0.2$ & $5.4 \pm 0.9$ & $4.2 \pm 0.8$ \\
\hline $\mathrm{U}^{* 4-\mathrm{yr}}$ & $6.4 \pm 0.3$ & $6.3 \pm 0.3$ & $3.0 \pm 0.4$ & $2.8 \pm 0.5$ & $6.4 \pm 0.3$ & $6.4 \pm 0.2$ & $3.7 \pm 0.9$ & $2.9 \pm 0.8$ \\
\hline $\mathrm{U}^{*} 7-\mathrm{yr}$ & $6.2 \pm 0.2$ & $6.2 \pm 0.3$ & $3.9 \pm 0.7$ & $3.3 \pm 0.5$ & $6.3 \pm 0.2$ & $6.2 \pm 0.2$ & $3.4 \pm 0.6$ & $3.0 \pm 0.6$ \\
\hline Grand Mean & $6.8 \pm 0.2$ & $6.7 \pm 0.3$ & $4.5 \pm 0.7$ & $3.7 \pm 0.6$ & $6.7 \pm 0.2$ & $6.7 \pm 0.2$ & $4.8 \pm 0.9$ & $3.8 \pm 0.9$ \\
\hline & \multicolumn{8}{|c|}{ Pr $>\mathbf{F}$} \\
\hline Block & 0.1717 & 0.1972 & $<.0001$ & 0.0014 & 0.0032 & 0.0260 & $<.0001$ & $<.0001$ \\
\hline Composted Manure & $<.0001$ & $<.0001$ & $<.0001$ & $<.0001$ & $<.0001$ & $<.0001$ & $<.0001$ & $<.0001$ \\
\hline Rotation Cycle & 0.9432 & 0.9523 & 0.0473 & $<.0001$ & 0.0085 & 0.0013 & 0.0008 & 0.0079 \\
\hline Manure* Rotation & 0.0088 & 0.0237 & $<.0001$ & 0.0581 & 0.3216 & 0.9904 & 0.0198 & 0.0040 \\
\hline
\end{tabular}

*Different letters within a column indicate significant difference at $\alpha=0.1$ within factor. Values following the \pm symbol are the standard deviation.

M=Manured plots; $\mathrm{U}=$ Unmanured plots. 
Table 22. Main effects of manure and rotation (4-yr and 7-yr) on 2014 stratified soil test phosphorus (STP) and soil test potassium (STK) under the first (corn) and last (kale) crop component of the rotation.

\begin{tabular}{|c|c|c|c|c|c|c|c|c|}
\hline \multirow[t]{3}{*}{2014} & \multicolumn{4}{|c|}{ Corn } & \multicolumn{4}{|c|}{ Kale } \\
\hline & \multicolumn{2}{|c|}{$\mathrm{STP}(\mathrm{mg} / \mathrm{kg})$} & \multicolumn{2}{|c|}{ STK $(\mathrm{mg} / \mathrm{kg})$} & \multicolumn{2}{|c|}{$\mathrm{STP}(\mathrm{mg} / \mathrm{kg})$} & \multicolumn{2}{|c|}{ STK (mg/kg) } \\
\hline & $0-5 \mathrm{~cm}$ & $5-10 \mathrm{~cm}$ & $0-5 \mathrm{~cm}$ & $5-10 \mathrm{~cm}$ & $0-5 \mathrm{~cm}$ & $5-10 \mathrm{~cm}$ & $0-5 \mathrm{~cm}$ & $5-10 \mathrm{~cm}$ \\
\hline \multicolumn{9}{|l|}{ Composted Manure } \\
\hline M & $86.4^{\mathrm{a}} \pm 21.6$ & $57.5^{\mathrm{a}} \pm 21.7$ & $326.3^{\mathrm{a}} \pm 57.5$ & $233.2^{\mathrm{a}} \pm 52.6$ & $101.3^{\mathrm{a}} \pm 29.5$ & $80.0^{\mathrm{a}} \pm 31.9$ & $257.7^{\mathrm{a}} \pm 60.4$ & $143.5^{\mathrm{a}} \pm 43.5$ \\
\hline $\mathrm{U}$ & $9.5^{\mathrm{b}} \pm 4.8$ & $7.6^{\mathrm{b}} \pm 3.6$ & $169.8^{b} \pm 50.7$ & $100.7^{\mathrm{b}} \pm 32.7$ & $17.2^{\mathrm{b}} \pm 6.1$ & $12.9^{\mathrm{b}} \pm 5.4$ & $121.2^{\mathrm{b}} \pm 22.5$ & $63.9^{\mathrm{b}} \pm 12.4$ \\
\hline \multicolumn{9}{|l|}{ Rotation Cycle } \\
\hline $4-y r$ & $40.2^{\mathrm{b}} \pm 14.1$ & $30.0^{\mathrm{a}} \pm 13$ & $230.8^{\mathrm{b}} \pm 44.1$ & $155.2^{\mathrm{b}} \pm 38.9$ & $90.2^{\mathrm{a}} \pm 26.3$ & $73.3^{\mathrm{a}} \pm 29.2$ & $215.2^{\mathrm{a}} \pm 45.9$ & $125.0^{\mathrm{a}} \pm 35.3$ \\
\hline $7-\mathrm{yr}$ & $57.3^{\mathrm{a}} \pm 12.2$ & $36.0^{\mathrm{a}} \pm 12$ & $268.6^{\mathrm{a}} \pm 64.1$ & $181.3^{a} \pm 46.4$ & $28.3^{\mathrm{b}} \pm 9.4$ & $19.6^{\mathrm{b}} \pm 8.1$ & $163.7^{b} \pm 37$ & $82.3^{b} \pm 20.7$ \\
\hline \multicolumn{9}{|l|}{ Manure*Rotation } \\
\hline$M * 4-y r$ & $72.9 \pm 25.1$ & $53.7 \pm 23.8$ & $340.9 \pm 46.9$ & $238.9 \pm 46.1$ & $159.2 \pm 44.2$ & $131.0 \pm 51.3$ & $303.7 \pm 68.3$ & $184.9 \pm 58.0$ \\
\hline $\mathrm{M} * 7-\mathrm{yr}$ & $99.9 \pm 18.0$ & $61.2 \pm 19.5$ & $311.7 \pm 68.0$ & $227.5 \pm 59.0$ & $43.3 \pm 14.8$ & $29.1 \pm 12.4$ & $211.7 \pm 52.5$ & $102.1 \pm 29.0$ \\
\hline $\mathrm{U} * 4-\mathrm{yr}$ & $7.5 \pm 3.1$ & $6.3 \pm 2.7$ & $120.7 \pm 41.2$ & $71.6 \pm 31.6$ & $21.1 \pm 8.3$ & $15.7 \pm 7.0$ & $126.7 \pm 23.4$ & $65.2 \pm 12.5$ \\
\hline $\mathrm{U} * 7-\mathrm{yr}$ & $11.6 \pm 6.4$ & $9.1 \pm 4.5$ & $222.4 \pm 60.1$ & $131.9 \pm 33.7$ & $13.2 \pm 3.9$ & $10.1 \pm 3.8$ & $115.7 \pm 21.5$ & $62.5 \pm 12.3$ \\
\hline Grand Mean & $48.6 \pm 13.2$ & $33.0 \pm 12.6$ & $249.4 \pm 54.1$ & $168.1 \pm 42.6$ & $59.2 \pm 17.8$ & $46.5 \pm 18.6$ & $189.5 \pm 41.4$ & $103.7 \pm 28$ \\
\hline & \multicolumn{8}{|c|}{ Pr $>F$} \\
\hline Block & 0.1898 & 0.4581 & 0.0097 & 0.4774 & 0.1704 & 0.1504 & 0.8335 & 0.2764 \\
\hline Composted Manure & $<.0001$ & $<.0001$ & $<.0001$ & $<.0001$ & $<.0001$ & $<.0001$ & $<.0001$ & $<.0001$ \\
\hline Rotation Cycle & 0.0003 & 0.2105 & 0.0108 & 0.0417 & $<.0001$ & $<.0001$ & $<.0001$ & $<.0001$ \\
\hline Manure* Rotation & 0.0083 & 0.5873 & $<.0001$ & 0.0034 & $<.0001$ & $<.0001$ & 0.0014 & $<.0001$ \\
\hline
\end{tabular}

*Different letters within a column indicate significant difference at $\alpha=0.1$ within factor. Values following the \pm symbol are the standard deviation.

M=Manured plots; $\mathrm{U}=$ Unmanured plots. 
Table 23. Main effects of manure and rotation (4-yr and 7-yr) on stratified 2014 soil test calcium (STCa) and soil test magnesium (STMg) under the first (corn) and last (kale) crop component of the rotation.

\begin{tabular}{|c|c|c|c|c|c|c|c|c|}
\hline \multirow[t]{3}{*}{2014} & \multicolumn{4}{|c|}{ Corn } & \multicolumn{4}{|c|}{ Kale } \\
\hline & \multicolumn{2}{|c|}{ STCa $(\mathrm{mg} / \mathrm{kg})$} & \multicolumn{2}{|c|}{$\mathrm{STMg}(\mathrm{mg} / \mathrm{kg})$} & \multicolumn{2}{|c|}{ STCa $(\mathrm{mg} / \mathrm{kg})$} & \multicolumn{2}{|c|}{ STMg $(\mathrm{mg} / \mathrm{kg})$} \\
\hline & $0-5 \mathrm{~cm}$ & $5-10 \mathrm{~cm}$ & $0-5 \mathrm{~cm}$ & $5-10 \mathrm{~cm}$ & $0-5 \mathrm{~cm}$ & $5-10 \mathrm{~cm}$ & $0-5 \mathrm{~cm}$ & $5-10 \mathrm{~cm}$ \\
\hline \multicolumn{9}{|l|}{ Composted Manure } \\
\hline $\mathrm{M}$ & $2397^{\mathrm{a}} \pm 470$ & $2318.3^{\mathrm{a}} \pm 456$ & $207.0^{\mathrm{a}} \pm 35.7$ & $181.8^{\mathrm{a}} \pm 37.2$ & $2328^{\mathrm{a}} \pm 402$ & $2302^{a} \pm 460$ & $209^{\mathrm{a}} \pm 37.9$ & $198.6^{\mathrm{a}} \pm 41.2$ \\
\hline $\mathrm{U}$ & $1430^{\mathrm{b}} \pm 423$ & $1469.2^{b} \pm 424$ & $125.4^{\mathrm{b}} \pm 45.9$ & $118.2^{\mathrm{b}} \pm 51.3$ & $1214^{b} \pm 280$ & $1221^{\mathrm{b}} \pm 286$ & $120^{\mathrm{b}} \pm 29.3$ & $111.2^{\mathrm{b}} \pm 35.1$ \\
\hline \multicolumn{9}{|l|}{ Rotation Cycle } \\
\hline $4-y r$ & $1729^{b} \pm 514$ & $1778^{\mathrm{b}} \pm 543$ & $160.6^{\mathrm{a}} \pm 39.1$ & $149.1^{\mathrm{a}} \pm 40$ & $1876^{\mathrm{a}} \pm 404$ & $1885^{\mathrm{a}} \pm 469$ & $155.7^{\mathrm{b}} \pm 31$ & $150.1^{\mathrm{a}} \pm 39.1$ \\
\hline $7-\mathrm{yr}$ & $2120^{\mathrm{a}} \pm 380$ & $2029^{\mathrm{a}} \pm 449$ & $173.4^{\mathrm{a}} \pm 42.5$ & $152.0^{\mathrm{a}} \pm 48.5$ & $1666^{b} \pm 277$ & $1638^{\mathrm{b}} \pm 277$ & $173.0^{\mathrm{a}} \pm 37$ & $159.7^{a} \pm 34.8$ \\
\hline \multicolumn{9}{|l|}{ Manure*Rotation } \\
\hline$M^{* 4-y r}$ & $2049 \pm 639.5$ & $2068 \pm 651.9$ & $204.8 \pm 37.3$ & $183.9 \pm 29.5$ & $2593 \pm 509$ & $2577 \pm 644$ & $199 \pm 36.6$ & $192.5 \pm 43.3$ \\
\hline $\mathrm{M} * 7-\mathrm{yr}$ & $2745 \pm 302.0$ & $2569 \pm 485.7$ & $209.3 \pm 34.1$ & $179.7 \pm .44 .9$ & $2061 \pm 295$ & $2027 \pm 277$ & $218 \pm 39.2$ & $204.7 \pm 39.1$ \\
\hline $\mathrm{U} * 4-\mathrm{yr}$ & $1409 \pm 389.0$ & $1487 \pm 435.4$ & $116.4 \pm 40.9$ & $114.4 \pm 50.5$ & $1159 \pm 301$ & $1193 \pm 295$ & $112 \pm 24.7$ & $107.7 \pm 34.8$ \\
\hline $\mathrm{U} * 7-\mathrm{yr}$ & $1452 \pm 458.7$ & $1450 \pm 413.4$ & $135.0 \pm 50.8$ & $122.3 \pm 52.0$ & $1270 \pm 260$ & $1250 \pm 279$ & $128 \pm 33.9$ & $114.7 \pm 35.4$ \\
\hline Grand Mean & $1921 \pm 447$ & $1901 \pm 496$ & $166.9 \pm 40.8$ & $150.5 \pm 44.2$ & $1771 \pm 341$ & $1761 \pm 373$ & $164 \pm 33.6$ & $155 \pm 38.2$ \\
\hline & & & & $\operatorname{Pr}>\mathbf{F}$ & & & & \\
\hline Block & $<.0001$ & $<.0001$ & 0.0004 & 0.0044 & $<.0001$ & $<.0001$ & 0.0002 & 0.0026 \\
\hline Composted Manure & $<.0001$ & $<.0001$ & $<.0001$ & $<.0001$ & $<.0001$ & $<.0001$ & $<.0001$ & $<.0001$ \\
\hline Rotation Cycle & $<.0001$ & 0.0228 & 0.2252 & 0.8657 & 0.0035 & 0.0030 & 0.0274 & 0.2903 \\
\hline Manure* Rotation & 0.0002 & 0.0060 & 0.4554 & 0.5823 & $<.0001$ & 0.0003 & 0.8245 & 0.7714 \\
\hline
\end{tabular}

$*$ Different letters within a column indicate significant difference at $\alpha=0.1$ within factor. Values following the \pm symbol are the standard deviation.

$\mathrm{M}=$ Manured plots; U=Unmanured plots. 
Table 24. Main effects of manure and rotation (4-yr and 7-yr) on 2014 stratified soil test zinc (STZn) and total nitrogen (TotN) under the first (corn) and last (kale) crop component of the rotation.

\begin{tabular}{|c|c|c|c|c|c|c|c|c|}
\hline \multirow[t]{3}{*}{2014} & \multicolumn{4}{|c|}{ Corn } & \multicolumn{4}{|c|}{ Kale } \\
\hline & \multicolumn{2}{|c|}{ STZn $(\mathrm{mg} / \mathrm{kg})$} & \multicolumn{2}{|c|}{ TotN (g/kg) } & \multicolumn{2}{|c|}{ STZn $(\mathrm{mg} / \mathrm{kg})$} & \multicolumn{2}{|c|}{ TotN $(\mathrm{g} / \mathrm{kg})$} \\
\hline & $0-5 \mathrm{~cm}$ & $5-10 \mathrm{~cm}$ & $0-5 \mathrm{~cm}$ & $5-10 \mathrm{~cm}$ & $0-5 \mathrm{~cm}$ & $5-10 \mathrm{~cm}$ & $0-5 \mathrm{~cm}$ & $5-10 \mathrm{~cm}$ \\
\hline \multicolumn{9}{|l|}{ Composted Manure } \\
\hline $\mathrm{M}$ & $7.5^{\mathrm{a}} \pm 2.6$ & $6.1^{\mathrm{a}} \pm 2.4$ & $3.0^{\mathrm{a}} \pm 0.5$ & $2.5^{\mathrm{a}} \pm 0.4$ & $8.6^{\mathrm{a}} \pm 3.9$ & $7.8^{\mathrm{a}} \pm 4.4$ & $3.1^{\mathrm{a}} \pm 0.5$ & $2.5^{\mathrm{a}} \pm 0.5$ \\
\hline $\mathrm{U}$ & $2.2^{\mathrm{b}} \pm 0.4$ & $2.0^{\mathrm{b}} \pm 0.4$ & $1.9^{\mathrm{b}} \pm 0.2$ & $1.7^{\mathrm{b}} \pm 0.3$ & $2.6^{\mathrm{b}} \pm 0.9$ & $2.2^{\mathrm{b}} \pm 0.9$ & $1.9^{\mathrm{b}} \pm 0.4$ & $1.6^{\mathrm{b}} \pm 0.3$ \\
\hline \multicolumn{9}{|l|}{ Rotation Cycle } \\
\hline $4-y r$ & $4.3^{\mathrm{b}} \pm 1.5$ & $3.8^{\mathrm{a}} \pm 1.2$ & $2.1^{\mathrm{b}} \pm 0.3$ & $1.9^{\mathrm{b}} \pm 0.4$ & $7.1^{\mathrm{a}} \pm 3.9$ & $6.4^{\mathrm{a}} \pm 4.3$ & $2.6^{\mathrm{a}} \pm 0.5$ & $2.1^{\mathrm{a}} \pm 0.5$ \\
\hline $7-y r$ & $5.5^{\mathrm{a}} \pm 1.5$ & $4.3^{\mathrm{a}} \pm 1.6$ & $2.8^{\mathrm{a}} \pm 0.4$ & $2.3^{\mathrm{a}} \pm 0.3$ & $4.0^{\mathrm{b}} \pm 1.0$ & $3.5^{\mathrm{b}} \pm 1.0$ & $2.3^{\mathrm{b}} \pm 0.4$ & $2.0^{\mathrm{b}} \pm 0.3$ \\
\hline \multicolumn{9}{|l|}{ Manure*Rotation } \\
\hline $\mathrm{M} * 4-\mathrm{yr}$ & $6.5 \pm 2.5$ & $5.6 \pm 2.0$ & $2.5 \pm 0.4$ & $2.2 \pm 0.3$ & $11.8 \pm 6.6$ & $10.9 \pm 7.5$ & $3.3 \pm 0.5$ & $2.7 \pm 0.6$ \\
\hline $\mathrm{M} * 7-\mathrm{yr}$ & $8.5 \pm 2.6$ & $6.5 \pm 2.8$ & $3.4 \pm 0.5$ & $2.8 \pm 0.5$ & $5.3 \pm 1.2$ & $4.7 \pm 1.2$ & $2.8 \pm 0.4$ & $2.3 \pm 0.4$ \\
\hline $\mathrm{U} * 4-\mathrm{yr}$ & $2.2 \pm 0.4$ & $2.1 \pm 0.4$ & $1.7 \pm 0.1$ & $1.7 \pm 0.4$ & $2.4 \pm 1.1$ & $2.0 \pm 1.0$ & $1.9 \pm 0.4$ & $1.5 \pm 0.3$ \\
\hline $\mathrm{U} * 7-\mathrm{yr}$ & $2.3 \pm 0.4$ & $1.9 \pm 0.3$ & $2.0 \pm 0.2$ & $1.7 \pm 0.1$ & $2.7 \pm 0.7$ & $2.4 \pm 0.7$ & $1.9 \pm 0.3$ & $1.7 \pm 0.2$ \\
\hline Grand Mean & $4.9 \pm 1.5$ & $4.1 \pm 1.4$ & $2.4 \pm 0.3$ & $2.1 \pm 0.3$ & $5.6 \pm 2.4$ & $5.0 \pm 2.6$ & $2.5 \pm 0.4$ & $2.1 \pm 0.4$ \\
\hline & \multicolumn{8}{|c|}{ Pr $>\mathbf{F}$} \\
\hline Block & 0.0024 & 0.0066 & 0.0137 & 0.0280 & 0.0021 & 0.0018 & $<.0001$ & $<.0001$ \\
\hline Composted Manure & $<.0001$ & $<.0001$ & $<.0001$ & $<.0001$ & $<.0001$ & $<.0001$ & $<.0001$ & $<.0001$ \\
\hline Rotation Cycle & 0.0160 & 0.3737 & $<.0001$ & 0.0007 & 0.0003 & 0.0021 & 0.0016 & 0.0952 \\
\hline Manure* Rotation & 0.0286 & 0.2215 & 0.0007 & 0.0025 & 0.0001 & 0.0007 & 0.0033 & 0.0024 \\
\hline
\end{tabular}

$*$ Different letters within a column indicate significant difference at $\alpha=0.1$ within factor. Values following the \pm symbol are the standard deviation.

$\mathrm{M}=$ Manured plots; U=Unmanured plots. 
Table 25. Means, standard deviations, and coefficient of variation for the 2014 corn biomass per plant by treatment.

\begin{tabular}{ccccc}
\hline $\begin{array}{c}\text { Manure } \\
\text { Treatment }\end{array}$ & Stalk + Leaves $(\mathbf{g})$ & $\begin{array}{c}\text { Ear } \\
(\mathbf{g})\end{array}$ & $\begin{array}{c}\text { Kernels } \\
(\mathbf{g})\end{array}$ & $\begin{array}{c}\text { Total Biomass } \\
(\mathbf{g})\end{array}$ \\
\hline & & & 4-yr Rotation & \\
Manured & $176 \pm 48(27 \%)$ & $148 \pm 22(13 \%)$ & $125 \pm 19(15 \%)$ & $326 \pm 58(18 \%)$ \\
Unmanured & $128 \pm 47(36 \%)$ & $118 \pm 37(31 \%)$ & $102 \pm 34(34 \%)$ & $248 \pm 84(34 \%)$ \\
& & & & \\
Manured & & & 7-yr Rotation & $436 \pm 115(26 \%)$ \\
Unmanured & $145 \pm 12(8 \%)$ & $134 \pm 57(42 \%)$ & $87 \pm 11(13 \%)$ & $253 \pm 22(9 \%)$ \\
\hline \hline
\end{tabular}

* The coefficient of variation $(\mathrm{CV})$ for the treatments means is presented in parenthesis

Table 26. Effect of the 2014 manure treatment on cowpea, weed, and total biomass, 4-yr rotation.

\begin{tabular}{cccc}
\hline \hline Variables & Cowpeas Biomass & Weed Biomass & Total Biomass \\
& & $\mathbf{M g ~ h a}^{-1}$ & \\
M & $1.69^{\mathrm{a}} \pm 0.57$ & $3.09^{\mathrm{a}} \pm 1.08$ & $4.78^{\mathrm{a}} \pm 0.52$ \\
$\mathrm{U}$ & $2.29^{\mathrm{a}} \pm 1.50$ & $2.78^{\mathrm{a}} \pm 1.50$ & $5.06^{\mathrm{a}} \pm 0.60$ \\
Grand Mean & $2.08 \pm 1.23$ & & $4.97 \pm 0.54$ \\
& & $2.88 \pm 1.27$ & \\
Block & $\mathbf{P r}>\mathbf{F}$ & & 0.6343 \\
Manure & 0.3381 & 0.1571 & 0.9457 \\
\hline \hline
\end{tabular}

*Different letters within a column indicate significant difference at $\alpha=0.1$ within factor. Values following the \pm symbol are the standard deviation. $\mathrm{M}=$ Manured plots; $\mathrm{U}=$ Unmanured plots.

\section{EXPERIMENT II:}

\section{Within-Rotation Effect of Manure and Crop on Transition into and out of Temporary Grass Component}

In the next section 2013 soil physical properties [bulk density (BD), dry geometric mean diameter aggregation (DA-GMD), wet geometric mean diameter aggregation (WA-GMD), and soil organic matter at $0-10 \mathrm{~cm}$ depth $(\mathrm{SOM})]$ will be discussed in the context of the transition from crops to grass, and from grass back into crops (Table 27). Soil chemical properties (each from $0-5 \mathrm{~cm}$ and $5-10 \mathrm{~cm}$ ) will also be discussed in the context of the transition from crops to grass (kale to O5), and from grass back into crops (O7 to corn). Properties discussed will be $\mathrm{pH}$ 
( $\mathrm{KCl})$, SOM (\%), soil test phosphorus (STP), soil test potassium (STK), soil test Ca (STCa) and total nitrogen (TotN).

\section{Manure effect within rotation on transition into and out of grass component}

In 2013, as measured in the transition into the grass component, manure application had a significant effect on all soil physical properties measured. Bulk density was significantly lower in manured plots, compared to unmanured plots (Table 27). Dry Aggregate stability (GMD) was higher in unmanured plots, compared to manured plots. Wet Aggregate stability (GMD) and SOM were both higher in manured plots than in unmanured plots. In 2013, as measured in the transition into the grass component, manure application had a significant effect on $\mathrm{pH}$ and SOM at all depths (Table 28). In all cases, values were higher in manured plots than in unmanured plots. Soil test phosphorus and STK behaved similarly to $\mathrm{pH}$ and SOM. An effect of manure was observed at all depths; nutrients were higher in manured plots (Table 29). Soil test calcium and TotN also behaved similarly to the previously discussed nutrients. The effect of manure was significant on both nutrients at all depths, with significantly higher values in manured plots than those in unmanured plots (Table 30).

Transitioning out of the grass component, regardless of crop (O7 or corn) manured plots had significantly lower BD than plots in the unmanured treatment; however no significant effect of manure application was observed on DA-GMD, WA-GMD, or SOM. As was found for the transition from crops to grass, $\mathrm{pH}$ and $\mathrm{SOM}$ in the transition from grass to crops (third year of orchardgrass mix (O7) and first crop corn) were significantly affected by manure application (Table 28). At all depths, manured plots exhibited higher $\mathrm{pH}$ and SOM. This was also the case for STP, STK (Table 29), STCa and TotN (Table 30).

\section{Crop effect within rotation on transition into and out of grass component}

Crop treatment, represented by kale (last crop before grass) and first year of orchardgrass mix (O5), had a significant effect on physical properties. BD in O5 was significantly higher than that in the kale plots. Crop also had a significant effect on aggregate stability. Dry Aggregate 
stability (GMD) was significantly higher in O5 plots, compared to kale plots (Table 27). Wet Aggregate stability (GMD), however, was significantly higher in kale plots than it was in O5 plots. Soil organic matter was not significantly affected by crop. No effect of crop was observed on $\mathrm{pH}$ during the transition into the grass component. An effect of crop was only observed in stratified SOM at the 0-5cm depth; O5 plots had higher SOM than kale plots. An effect of crop was observed in both STP and STK but only at the $0-5 \mathrm{~cm}$ depth, in which O5 values were greater than those in kale. The effect of crop was also significant for both STCa and TotN at all depths. Nutrient values in the O5 plots were higher than those in the kale plots.

Concerning the transition from grass plots to crops, a significant effect of crop was observed on BD; corn plots had significantly lower BD than $\mathrm{O} 7$ plots, presumably due to tillage (Table 27). Crop also had a significant effect on aggregate stability. Corn plots had significantly higher DA-GMD than $\mathrm{O} 7$ plots, while O7 plots had significantly higher WA-GMD than corn plots. An effect of crop was observed in both $\mathrm{pH}$ and SOM, but only at the 5-10cm depth (Table 28). In both cases, nutrients were higher in $\mathrm{O} 7$ plots than in corn plots. An effect of crop was observed on STP and STK values for 2013 (Table 29). For both nutrients, values in corn plots were significantly higher than those in $\mathrm{O} 7$ plots, but only at the surface depth. A significant effect of crop was observed for STCa, but not for TotN (Table 30). Soil test calcium in O7 plots is significantly larger than in corn plots at all depths.

\section{Interaction between manure and crop on transition into and out of grass component}

An interaction between manure and crop was found for BD, DA-GMD, and SOM during the transition out of the grass component. For these properties, decrease in soil quality when manure was not applied was more evident in corn plots (high magnitude interaction).

An interaction of manure and crop was observed for $\mathrm{pH}$, regardless of the point in the transition. An interaction was found between manure and crop on TotN at all depths. An effect of block was only observed for SOM at the $5-10 \mathrm{~cm}$ depth. Interactions between manure and crop were found for $\mathrm{pH}$ at both depths, and for SOM at the surface $(0-5 \mathrm{~cm})$ depth. An interaction between manure and crop was found for STP at all depths and for STK at the 5-10cm depth. An interaction between manure and crop was observed for STCa at all depths regardless of the point in the transition, and for TotN at the $0-5 \mathrm{~cm}$ depth. 
Table 27. Transition from Grass into Crop Component, and Crop Component into Grass: Effect of manure and plant species on 2013 soil physical properties.

Transition into the grass component $\quad$ Transition into the crop component

\begin{tabular}{|c|c|c|c|c|c|c|c|c|c|}
\hline 2013 Variables & $\begin{array}{c}\mathrm{BD} \\
\mathrm{Mg} / \mathrm{m}^{3}\end{array}$ & $\begin{array}{c}\text { DA-GMD } \\
\mathrm{mm}\end{array}$ & $\begin{array}{c}\text { WA-GMD } \\
\mathrm{mm}\end{array}$ & $\begin{array}{c}\text { SOM } \\
\% \\
\end{array}$ & & $\begin{array}{c}\mathrm{BD} \\
\mathrm{Mg} / \mathrm{m}^{3}\end{array}$ & $\begin{array}{c}\text { DA-GMD } \\
\mathrm{mm}\end{array}$ & $\begin{array}{c}\text { WA-GMD } \\
\mathrm{mm}\end{array}$ & $\begin{array}{c}\text { SOM } \\
\% \\
\end{array}$ \\
\hline \multicolumn{10}{|l|}{ Manure } \\
\hline $\mathbf{M}$ & $1.11^{\mathrm{b}} \pm 0.07$ & $4.4^{\mathrm{b}} \pm 1.9$ & $3.8^{\mathrm{a}} \pm 1.2$ & $3.6^{\mathrm{a}} \pm 1.1$ & $\mathbf{M}$ & $1.14^{\mathrm{b}} \pm 0.10$ & $5.4^{\mathrm{a}} \pm 1.6$ & $5.2^{\mathrm{a}} \pm 0.5$ & $4.3^{\mathrm{a}} \pm 1.5$ \\
\hline $\mathbf{U}$ & $1.20^{\mathrm{a}} \pm 0.10$ & $5.6^{\mathrm{a}} \pm 2.3$ & $3.2^{\mathrm{b}} \pm 1.2$ & $3.1^{\mathrm{b}} \pm 0.9$ & $\mathbf{U}$ & $1.23^{\mathrm{a}} \pm 0.12$ & $5.9^{\mathrm{a}} \pm 1.7$ & $5.2^{\mathrm{a}} \pm 0.7$ & $3.4^{\mathrm{b}} \pm 1.0$ \\
\hline \multicolumn{10}{|l|}{ Crop } \\
\hline $\mathbf{K}$ & $1.14^{\mathrm{b}} \pm 0.08$ & $4.4^{\mathrm{b}} \pm 2.1$ & $4.7^{\mathrm{a}} \pm 0.9$ & $3.3^{\mathrm{a}} \pm 0.9$ & O7 & $1.24^{\mathrm{a}} \pm 0.11$ & $6.1^{\mathrm{a}} \pm 1.7$ & $5.5^{\mathrm{a}} \pm 0.3$ & $3.9^{\mathrm{a}} \pm 1.3$ \\
\hline 05 & $1.19^{\mathrm{a}} \pm 0.11$ & $6.4^{\mathrm{a}} \pm 1.7$ & $2.8^{\mathrm{b}} \pm 0.8$ & $3.4^{\mathrm{a}} \pm 1.2$ & $\mathbf{C}$ & $1.13^{\mathrm{b}} \pm 0.10$ & $5.1^{\mathrm{b}} \pm 1.5$ & $4.9^{b} \pm 0.6$ & $3.7^{\mathrm{a}} \pm 1.4$ \\
\hline \multicolumn{10}{|l|}{ Manure*Crop } \\
\hline $\mathbf{K}^{*} \mathbf{M}$ & $1.11 \pm 0.07$ & $3.7 \pm 1.8$ & $3.1 \pm 0.8$ & $3.6 \pm 1.0$ & 07*M & $1.16 \pm 0.09$ & $5.3 \pm 1.4$ & $5.4 \pm 0.4$ & $4.5 \pm 1.5$ \\
\hline O5*M & $1.11 \pm 0.07$ & $5.9 \pm 1.1$ & $4.9 \pm 0.7$ & $3.7 \pm 1.2$ & $\mathbf{C} * \mathbf{M}$ & $1.12 \pm 0.11$ & $5.4 \pm 1.9$ & $4.9 \pm 0.5$ & $3.9 \pm 1.5$ \\
\hline $\mathbf{K} * \mathbf{U}$ & $1.17 \pm 0.09$ & $4.9 \pm 2.2$ & $2.6 \pm 0.8$ & $3.1 \pm 0.8$ & $\mathbf{O} 7 * \mathbf{U}$ & $1.31 \pm 0.07$ & $7.0 \pm 1.6$ & $5.6 \pm 0.3$ & $3.4 \pm 0.7$ \\
\hline $\mathbf{O 5} * \mathbf{U}$ & $1.26 \pm 0.09$ & $6.9 \pm 2.1$ & $4.5 \pm 0.8$ & $3.1 \pm 1.1$ & $\mathbf{C} * \mathbf{U}$ & $1.14 \pm 0.09$ & $4.8 \pm 1.0$ & $4.9 \pm 0.8$ & $3.5 \pm 1.3$ \\
\hline Grand Mean & $1.15 \pm 0.10$ & $5.0 \pm 2.2$ & $4.7 \pm 0.1$ & $3.9 \pm 0.9$ & $\begin{array}{l}\text { Grand } \\
\text { Mean }\end{array}$ & $1.18 \pm 0.11$ & $5.6 \pm 1.7$ & $5.2 \pm 0.6$ & $3.6 \pm 0.8$ \\
\hline & \multicolumn{4}{|c|}{ Pr $>$ F } & & \multicolumn{4}{|c|}{$\operatorname{Pr}>\mathbf{F}$} \\
\hline Block & 0.7322 & 0.0002 & 0.1375 & $<.0001$ & & 0.0128 & 0.0008 & 0.3022 & 0.1291 \\
\hline Manure & $<.0001$ & 0.0025 & 0.0043 & $<.0001$ & & 0.0002 & 0.1363 & 0.7929 & $<.0001$ \\
\hline Crop & 0.0174 & $<.0001$ & $<.0001$ & 0.4413 & & $<.0001$ & 0.0038 & 0.0001 & 0.3108 \\
\hline Manure*Crop & 0.0168 & 0.8081 & 0.8688 & 0.6031 & & 0.0100 & 0.0013 & 0.4725 & 0.0921 \\
\hline
\end{tabular}

*Different letters within a column indicate significant difference at $\alpha=0.1$ within factor. Values following the \pm symbol are the standard deviation.

$\mathrm{BD}=$ Bulk Density; DA-GMD=Dry aggregate geometric mean diameter; WA-GMD=Wet aggregate geometric mean diameter; SOM (0-10cm) = Soil organic matter; $\mathrm{M}=$ Manured plots; $\mathrm{U}=$ Unmanured plots; $\mathrm{C}=\mathrm{Corn}$; $\mathrm{O}$ = Last year in grass; K=Kale; O5=First year in grass. 
Table 28. Transition from Grass into Crop Component, and Crop into Grass Component: Effect of manure and plant species on 2013 stratified soil $\mathrm{pH}(\mathrm{KCl})$ and soil organic matter $(\mathrm{SOM})$.

\begin{tabular}{|c|c|c|c|c|c|c|c|c|c|}
\hline \multirow[b]{3}{*}{2013 Variables } & \multicolumn{4}{|c|}{ Transition into the grass component } & & \multicolumn{4}{|c|}{ Transition into the crop component } \\
\hline & \multicolumn{2}{|c|}{$\mathrm{pH}(\mathrm{KCl})$} & \multicolumn{2}{|c|}{$\operatorname{SOM}(\%)$} & & \multicolumn{2}{|c|}{$\mathrm{pH}(\mathrm{KCl})$} & \multicolumn{2}{|c|}{$\operatorname{SOM}(\%)$} \\
\hline & $0-5 \mathrm{~cm}$ & $5-10 \mathrm{~cm}$ & $0-5 \mathrm{~cm}$ & $5-10 \mathrm{~cm}$ & & $0-5 \mathrm{~cm}$ & $5-10 \mathrm{~cm}$ & $0-5 \mathrm{~cm}$ & $5-10 \mathrm{~cm}$ \\
\hline \multicolumn{10}{|l|}{ Manure } \\
\hline $\mathbf{M}$ & $5.70^{\mathrm{a}} \pm 0.27$ & $5.63^{\mathrm{a}} \pm 0.31$ & $4.5^{\mathrm{a}} \pm 0.6$ & $3.9^{\mathrm{a}} \pm 0.7$ & $\mathbf{M}$ & $5.96^{\mathrm{a}} \pm 0.27$ & $5.82^{\mathrm{a}} \pm 0.39$ & $6.0^{\mathrm{a}} \pm 0.9$ & $4.0^{\mathrm{a}} \pm 0.8$ \\
\hline $\mathbf{U}$ & $5.18^{\mathrm{b}} \pm 0.46$ & $5.14^{\mathrm{b}} \pm 0.54$ & $3.6^{\mathrm{b}} \pm 0.8$ & $3.3^{\mathrm{b}} \pm 0.7$ & $\mathbf{U}$ & $5.33^{\mathrm{b}} \pm 0.43$ & $5.07^{\mathrm{b}} \pm 0.46$ & $4.5^{\mathrm{b}} \pm 0.8$ & $3.3^{\mathrm{b}} \pm 0.7$ \\
\hline \multicolumn{10}{|l|}{ Crop } \\
\hline $\mathbf{K}$ & $5.41^{\mathrm{a}} \pm 0.44$ & $5.38^{\mathrm{a}} \pm 0.48$ & $3.9^{\mathrm{b}} \pm 0.7$ & $3.6^{\mathrm{a}} \pm 0.8$ & $\mathbf{O 7}$ & $5.66^{\mathrm{a}} \pm 0.60$ & $5.58^{\mathrm{a}} \pm 0.69$ & $5.2^{\mathrm{a}} \pm 1.3$ & $3.9^{\mathrm{a}} \pm 0.8$ \\
\hline $\mathbf{O 5}$ & $5.51^{\mathrm{a}} \pm 0.50$ & $5.40^{\mathrm{a}} \pm 0.55$ & $4.2^{\mathrm{a}} \pm 1.0$ & $3.7^{\mathrm{a}} \pm 0.8$ & $\mathbf{C}$ & $5.64^{\mathrm{a}} \pm 0.31$ & $5.33^{\mathrm{b}} \pm 0.39$ & $5.3^{\mathrm{a}} \pm 0.9$ & $3.5^{\mathrm{b}} \pm 0.8$ \\
\hline \multicolumn{10}{|l|}{ Manure*Crop } \\
\hline $\mathbf{K} * \mathbf{M}$ & $5.58 \pm 0.24$ & $5.53 \pm 0.31$ & $4.3 \pm 0.6$ & $3.9 \pm 0.7$ & $\mathbf{0 7} * \mathbf{M}$ & $6.17 \pm 0.10$ & $6.14 \pm 0.18$ & $6.4 \pm 0.7$ & $4.3 \pm 0.8$ \\
\hline $05 * M$ & $5.93 \pm 0.18$ & $5.84 \pm 0.18$ & $4.7 \pm 0.6$ & $3.3 \pm 0.6$ & $\mathbf{C} * \mathbf{M}$ & $5.74 \pm 0.19$ & $5.51 \pm 0.25$ & $5.7 \pm 0.9$ & $3.7 \pm 0.8$ \\
\hline $\mathbf{K} * \mathbf{U}$ & $5.23 \pm 0.51$ & $5.22 \pm 0.57$ & $3.5 \pm 0.5$ & $3.1 \pm 0.7$ & $\mathbf{0 7 * U}$ & $5.12 \pm 0.40$ & $4.99 \pm 0.49$ & $4.0 \pm 0.4$ & $3.4 \pm 0.6$ \\
\hline $\mathbf{0 5} * \mathbf{U}$ & $5.09 \pm 0.33$ & $4.97 \pm 0.44$ & $3.8 \pm 1.1$ & $3.3 \pm 0.7$ & $\mathbf{C} * \mathbf{U}$ & $5.53 \pm 0.37$ & $5.14 \pm 0.42$ & $4.9 \pm 0.8$ & $3.2 \pm 0.8$ \\
\hline Grand Mean & $5.44 \pm 0.46$ & $5.38 \pm 0.50$ & $4.0 \pm 0.8$ & $3.7 \pm 0.7$ & & $5.65 \pm 0.47$ & $5.45 \pm 0.57$ & $5.3 \pm 1.2$ & $3.7 \pm 0.8$ \\
\hline & \multicolumn{4}{|c|}{$\operatorname{Pr}>\mathbf{F}$} & & \multicolumn{4}{|c|}{$\operatorname{Pr}>\mathbf{F}$} \\
\hline Block & 0.0010 & 0.0309 & $<.0001$ & 0.0002 & & 0.7425 & 0.2335 & 0.2191 & 0.0006 \\
\hline Manure & $<.0001$ & $<.0001$ & $<.0001$ & $<.0001$ & & $<.0001$ & $<.0001$ & $<.0001$ & $<.0001$ \\
\hline Crop & 0.1783 & 0.7916 & 0.0227 & 0.4301 & & 0.8909 & 0.0125 & 0.4338 & 0.0365 \\
\hline Manure*Crop & 0.0016 & 0.0031 & 0.5502 & 0.2237 & & $<.0001$ & $<.0001$ & 0.0002 & 0.1755 \\
\hline
\end{tabular}

*Different letters within a column indicate significant difference at $\alpha=0.1$ within factor. Values following the \pm symbol are the standard deviation.

$\mathrm{SOM}=$ Soil organic matter; $\mathrm{M}=$ Manured plots; $\mathrm{U}=$ Unmanured plots; $\mathrm{C}=\mathrm{Corn}$; $\mathrm{O}$ = Last year in grass; $\mathrm{K}=\mathrm{Kale}$; O5=First year in grass 
Table 29. Transition from Grass into Crop Component, and Crop into Grass Component: Effect of manure and plant species on 2013 stratified soil $\mathrm{P}(\mathrm{mg} / \mathrm{kg})$ and $\mathrm{K}(\mathrm{mg} / \mathrm{kg})$.

Transition into the grass component $\quad$ Transition into the crop component

2013 Variables

$\mathrm{STP}(\mathrm{mg} / \mathrm{kg})$

$5-10 \mathrm{~cm}$ $\mathrm{STP}(\mathrm{mg} / \mathrm{kg})$

$5-10 \mathrm{~cm}$

$0-5 \mathrm{~cm}$ $\mathrm{STK}(\mathrm{mg} / \mathrm{kg})$

Manure

$\begin{array}{lllll}\mathbf{M} & 42.3^{\mathrm{a}} \pm 18.1 & 36.1^{\mathrm{a}} \pm 17.3 & 149.1^{\mathrm{a}} \pm 35.8 & 112.6^{\mathrm{a}} \pm 25 \\ \mathbf{U} & 15.1^{\mathrm{b}} \pm 6.1 & 13.2^{\mathrm{b}} \pm 5.9 & 109.4^{\mathrm{b}} \pm 25.5 & 87.0^{\mathrm{b}} \pm 23.1\end{array}$

M $\quad 84.48^{\mathrm{a}} \pm 24.6$

U $\quad 42.19^{\mathrm{b}} \pm 34.5$

$46.78^{\mathrm{a}} \pm 16.5$ $22.95^{\mathrm{b}} \pm 21.3$

$195.4^{\mathrm{a}} \pm 64.6$

$157.24^{\mathrm{b}} \pm 44$

$137.31^{\mathrm{a}} \pm 48.3$

$109.4^{\mathrm{b}} \pm 25.5 \quad 87.0^{\mathrm{b}} \pm 23.1$

Crop

$\begin{array}{rrrrr}\mathbf{K} & 27.1^{\mathrm{b}} \pm 16.4 & 23.5^{\mathrm{a}} \pm 14.9 & 125.7^{\mathrm{b}} \pm 33.7 & 102^{\mathrm{a}} \pm 28.6 \\ \mathbf{O 5} & 32.0^{\mathrm{a}} \pm 23.6 & 27.1^{\mathrm{a}} \pm 21.2 & 136.3^{\mathrm{a}} \pm 41.9 & 95.5^{\mathrm{a}} \pm 23.9\end{array}$

$27.1^{\mathrm{a}} \pm 21.2$

$136.3^{\mathrm{a}} \pm 41.9$

$95.5^{\mathrm{a}} \pm 23.9$

O7 $\quad 54.19^{\mathrm{b}} \pm 38.7$

$164.66^{\mathrm{b}} \pm 41$

$188.27^{\mathrm{a}} \pm 70$

$121.6^{\mathrm{a}} \pm 28$

C $\quad 72.88^{\mathrm{a}} \pm 32.3$

$37.52^{\mathrm{a}} \pm 23.0$

\section{Manure*Crop}

$\begin{array}{rc}\mathbf{K} * \mathbf{M} & 37.1 \pm 17.3 \\ \mathbf{O 5} * \mathbf{M} & 52.8 \pm 15.2 \\ \mathbf{K} * \mathbf{U} & 17.0 \pm 6.4 \\ \mathbf{O 5} * \mathbf{U} & 11.2 \pm 2.4\end{array}$

$\begin{array}{ccc}32.0 \pm 16.2 & 143.0 \pm 32.9 & 116.3 \pm 26.2 \\ 44.4 \pm 16.8 & 161.2 \pm 39.4 & 105.1 \pm 21.3 \\ 15.0 \pm 6.4 & 24.7 \pm 24.7 & 87.6 \pm 23.6\end{array}$

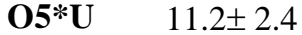

$9.7 \pm 2.5$

$27.8 \pm 27.8$

$85.8 \pm 23.0$
O7*M $\quad 87.1 \pm 22.0$
$\mathbf{C} * \mathbf{M} \quad 81.9 \pm 27.6$
O7*U $\quad 19.0 \pm 11.1$

C*U $\quad 63.9 \pm 35.2$

\section{$44.1 \pm 16.0$}

$49.5 \pm 17.2$

$179.2 \pm 43.9$

$14.4 \pm 8.16$

$211.6 \pm 78.6$

$149.0 \pm 31.4$

$164.9 \pm 53.4$

$130.2 \pm 32.0$

$144.4 \pm 61.0$

$30.9 \pm 26.7$

$63.7 \pm 36.6$

$35.1 \pm 22.4$

$176.7 \pm 58.3$

$92.4+33.6$

Grand Mean $\quad 28.7 \pm 19.1$
$24.7 \pm 17.2$
$129.2 \pm 36.8$
$99.8 \pm 27.2$

\section{Pr $>$ F}

\begin{tabular}{lllll} 
Block & 0.0119 & 0.0141 & $<.0001$ & 0.0003 \\
Manure & $<.0001$ & $<.0001$ & $<.0001$ & $<.0001$ \\
Crop & 0.0663 & 0.1803 & 0.0759 & 0.195 \\
Manure*Crop & 0.0001 & 0.0011 & 0.2098 & 0.345 \\
\hline \hline
\end{tabular}

$\begin{array}{ll}0.0003 & 0.0021 \\ <.0001 & <.0001 \\ 0.1952 & 0.0015 \\ 0.3453 & <.0001\end{array}$
0.0021
0.0015

$<.0001$
0.0317
$<.0001$
0.2020

Pr $>$ F

$<.0001$
0.0013

0.0346

0.5583

$120.0 \pm 43.7$

*Different letters within a column indicate significant difference at $\alpha=0.1$ within factor. Values following the \pm symbol are the standard deviation.

$\mathrm{SOM}=$ Soil organic matter; $\mathrm{M}=$ Manured plots; $\mathrm{U}=$ Unmanured plots; $\mathrm{C}=\mathrm{Corn}$; $\mathrm{O} 7=$ Last year in grass; K=Kale; O5=First year in grass. 
Table 30. Transition from Grass into Crop Component, and Crop into Grass Component: Effect of manure and plant species on 2013 stratified soil $\mathrm{Ca}(\mathrm{mg} / \mathrm{kg})$ and $\mathrm{TotN}(\mathrm{g} / \mathrm{kg})$.

$\begin{array}{ll}\text { Transition into the grass component } & \text { Transition into the crop component }\end{array}$

2013 Variables

$\mathrm{STCa}(\mathrm{mg} / \mathrm{kg}) \quad \operatorname{TotN}(\mathrm{g} / \mathrm{kg})$

$5-10 \mathrm{~cm}$ $\mathrm{STCa}(\mathrm{mg} / \mathrm{kg})$

$5-10 \mathrm{~cm}$
$0-5 \mathrm{~cm}$

Manure

M $\quad 1958^{\mathrm{a}} \pm 460$

$\begin{array}{rr}\mathbf{U} & 1690^{\mathrm{b}} \pm 556\end{array}$

$1975^{\mathrm{a}} \pm 502$

$1749^{\mathrm{b}} \pm 638$

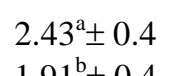

$2.20^{\mathrm{a}} \pm 0.4$

$0-5 \mathrm{~cm}$

$5-10 \mathrm{~cm}$ $0-5 \mathrm{~cm}$

$5-10 \mathrm{~cm}$

Crop

$\begin{array}{rrrrrrrrr}\mathbf{K} & 1728^{\mathrm{b}} \pm 537 & 1757^{\mathrm{b}} \pm 605 & 2.11^{\mathrm{b}} \pm 0.3 & 1.92^{\mathrm{b}} \pm 0.3 & \mathbf{O}^{\mathrm{a}} & 2135^{\mathrm{a}} \pm 714 & 2076^{\mathrm{a}} \pm 778 & 2.80^{\mathrm{a}} \pm 0.7 \\ \mathbf{O 5} & 2015^{\mathrm{a}} \pm 451 & 2072^{\mathrm{a}} \pm 476 & 2.29^{\mathrm{a}} \pm 0.6 & 2.08^{\mathrm{a}} \pm 0.6 & \mathbf{C} & 1938^{\mathrm{b}} \pm 454 & 1770^{\mathrm{b}} \pm 568 & 2.06^{\mathrm{a}} \pm 0.4\end{array}$

Manure*Crop

$\begin{array}{rrrrr}\mathbf{K} * \mathbf{M} & 1849 \pm 512 & 1843 \pm 543 & 2.3 \pm 0.3 & 2.1 \pm 0.3 \\ \mathbf{O 5} \mathbf{M} & 2177 \pm 214 & 2240 \pm 264 & 2.7 \pm 0.5 & 2.4 \pm 0.5 \\ \mathbf{K} * \mathbf{U} & 1608 \pm 542 & 1671 \pm 659 & 1.9 \pm 0.2 & 1.8 \pm 0.3 \\ \mathbf{O 5} \mathbf{U} & 1854 \pm 565 & 1905 \pm 583 & 1.9 \pm 0.5 & 1.7 \pm 0.4 \\ & & & & \\ & & & \\ & 1824 \pm 525 & 1862 \pm 582 & 2.2 \pm 0.5 & 2.0 \pm 0.4\end{array}$

$\begin{array}{rrrrr}\mathbf{O} 7 * \mathbf{M} & 2711 \pm 255 & 2552 \pm 627 & 3.4 \pm 0.3 & 2.3 \pm 0.4 \\ \mathbf{C} * \mathbf{M} & 2142 \pm 428 & 2043 \pm 572 & 3.0 \pm 0.4 & 2.1 \pm 0.4 \\ \mathbf{O 7} * \mathbf{U} & 1517 \pm 484 & 1567 \pm 583 & 2.2 \pm 0.2 & 1.8 \pm 0.2 \\ \mathbf{C} * \mathbf{U} & 1735 \pm 394 & 1498 \pm 429 & 2.6 \pm 0.4 & 1.8 \pm 0.4 \\ & & & & \\ & 2035 \pm 599 & 1921 \pm 691 & 2.8 \pm 0.6 & 2.0 \pm 0.4\end{array}$

\begin{tabular}{|c|c|c|c|c|c|c|c|c|}
\hline \multirow[b]{2}{*}{ Block } & \multicolumn{4}{|c|}{ Pr $>F$} & \multicolumn{4}{|c|}{ Pr $>$ F } \\
\hline & $<.0001$ & $<.0001$ & $<.0001$ & $<.0001$ & 0.0011 & $<.0001$ & 0.1391 & 0.0038 \\
\hline Manure & 0.0012 & 0.0202 & $<.0001$ & $<.0001$ & $<.0001$ & $<.0001$ & $<.0001$ & $<.0001$ \\
\hline Crop & 0.0010 & 0.0025 & 0.0054 & 0.0257 & 0.0638 & 0.0215 & 0.9461 & 0.1392 \\
\hline Manure*Crop & 0.6282 & 0.4215 & 0.0035 & 0.0102 & $<.0001$ & 0.0771 & $<.0001$ & 0.1608 \\
\hline
\end{tabular}

$*$ Different letters within a column indicate significant difference at $\alpha=0.1$ within factor. Values following the \pm symbol are the standard deviation.

$\mathrm{SOM}=$ Soil organic matter; $\mathrm{M}=$ Manured plots; $\mathrm{U}=$ Unmanured plots; $\mathrm{C}=\mathrm{Corn}$; $\mathrm{O} 7=$ Last year in grass; $\mathrm{K}=\mathrm{Kale}$; O5=First year in grass. 


\section{Within-Rotation Effect of Manure and Crop on Transition into and out of Temporary Grass Component}

In this section 2014 soil physical properties [bulk density (BD), dry geometric mean diameter aggregation (DA-GMD), wet geometric mean diameter aggregation (WA-GMD), and soil organic matter at $0-10 \mathrm{~cm}$ depth $(\mathrm{SOM})]$ will be discussed in the context of the transition from crops into grass, and from grass back into crops (Table 31).

The 2014 stratified elements at depths of $0-5 \mathrm{~cm}$ and $5-10 \mathrm{~cm}$ selected as indicators of possible changes occurring in the transition from crops to grass, and from grass back into crops were: $\mathrm{pH}(\mathrm{KCl}), \mathrm{SOM}(\%)$, soil test phosphorus (STP), soil test potassium (STK), soil test calcium (STCa) and total nitrogen (TotN).

In the following section biomass production for the grass component will be analyzed. Table 35 shows the yields observed in 2013 and 2014 as affected by manure application and years into the transition.

\section{Manure effect within rotation on transition into and out of grass component}

In 2014, concerning the transition into the grass component, manure application had a significant effect on $\mathrm{BD}$, which was significantly lower in manured plots, compared to unmanured plots (Table 31). Dry aggregate stability was not significantly affected by manure application. Wet aggregate stability and SOM were both higher in unmanured plots than in manured plots. In 2014, concerning the transition into the grass component, manure application had a significant effect on pH, SOM, STP, STK, STCa, and TotN at all depths (Table 32-34). In all cases, values were higher in manured plots than in unmanured plots.

In the 2014, the transition from grass to crops (third year of orchardgrass mix (O7) and first crop corn), manure application and crop had a significant effect on BD, WA-GMD and SOM. Plots in the manure treatment had significantly lower BD, higher WA-GMD and higher SOM than plots in the unmanured treatment, regardless of crop. The DA-GMD was not affected by manure application. For the transition from the third year of grass (O7 to corn), as was found 
in 2013, in 2014 manure application significantly affected pH, SOM, STP, STK, STCa, and TotN (Table 32-34). At all depths, manured plots exhibited higher nutrients content.

In both years there is a statistically significant increase in grass biomass in previouslymanured plots.

\section{Crop effect within rotation on transition into and out of grass component}

As in 2013, in 2014 crop treatment (kale or O5) also had a significant effect on BD in the transition into the grass component. Bulk density in the first year of grass (O5) was significantly higher than that in the kale plots (before the transition). Different from 2013, in 2014 crop treatment did not have a significant effect on DA-GMD, WA-GMD, or SOM. An effect of crop (kale or O5) was only observed in stratified SOM at the $0-5 \mathrm{~cm}$ depth, as was the case in 2013. O5 plots had higher SOM than kale plots (Table 32). Related to STP, at all depths O5 exhibited statistically significantly greater values than those in kale. This was not observed for STK. As was observed in 2013, in 2014 the effect of crop (kale or O5) was also significant for TotN at all depths, but not for STCa. Nutrient values in the kale plots were higher than those in the O5 plots (Table 35).

Regarding the transition from grass into crops, corn plots exhibited on average lower BD, WA-GMD and SOM than O7 plots. As was found in 2013, corn plots had significantly higher DA-GMD than 07 plots, while 07 plots had significantly higher WA-GMD than corn plots. An effect of crop was observed only on the $5-10 \mathrm{~cm}$ depth SOM (Table 32). Soil organic matter values were higher in corn plots than in $\mathrm{O} 7$ plots. An effect of crop was observed on STK values for 2014 (Table 33). On average, STK values in corn plots were significantly higher than those in $\mathrm{O} 7$ plots at all depths. A significant effect of crop was observed for TotN at the $5-10 \mathrm{~cm}$ depth, but not for STCa (Table 34). In this case TotN in corn plots was significantly larger than in $\mathrm{O} 7$ plots.

Data did not indicate a significant change in biomass production during the transition, although from the first year to the last year in both 2013 and 2014, a general increase was observed. 
Interaction between manure and crop on transition into and out of grass component

An interaction was observed between manure and crop for BD and WA-GMD both during the transition into and out of the grass component. For the transition into the grass component, an interaction of manure and crop was observed for $\mathrm{pH}$ at all depths and for SOM at the surface depth. An interaction between manure and crop was found in both nutrients $\mathrm{P}$ and $\mathrm{K}$, at all depths. An interaction was found between manure and crop on STCa at all depths, and on TotN at the surface depth.

For the transition out of the grass component, interactions between manure and crop were not observed for $\mathrm{pH}$ or SOM. An interaction between manure and crop was observed for TotN at all depths and for STCa at the 0-5cm depth. Orchardgrass biomass data did not show an interaction between "years into the transition" and manure application for either 2013 or 2014 (Table 35). 
Table 31. Transition from Grass into Crop Component, and Crop Component into Grass: Effect of manure and plant species on 2014 soil physical properties.

Transition into the grass component Transition into the crop component

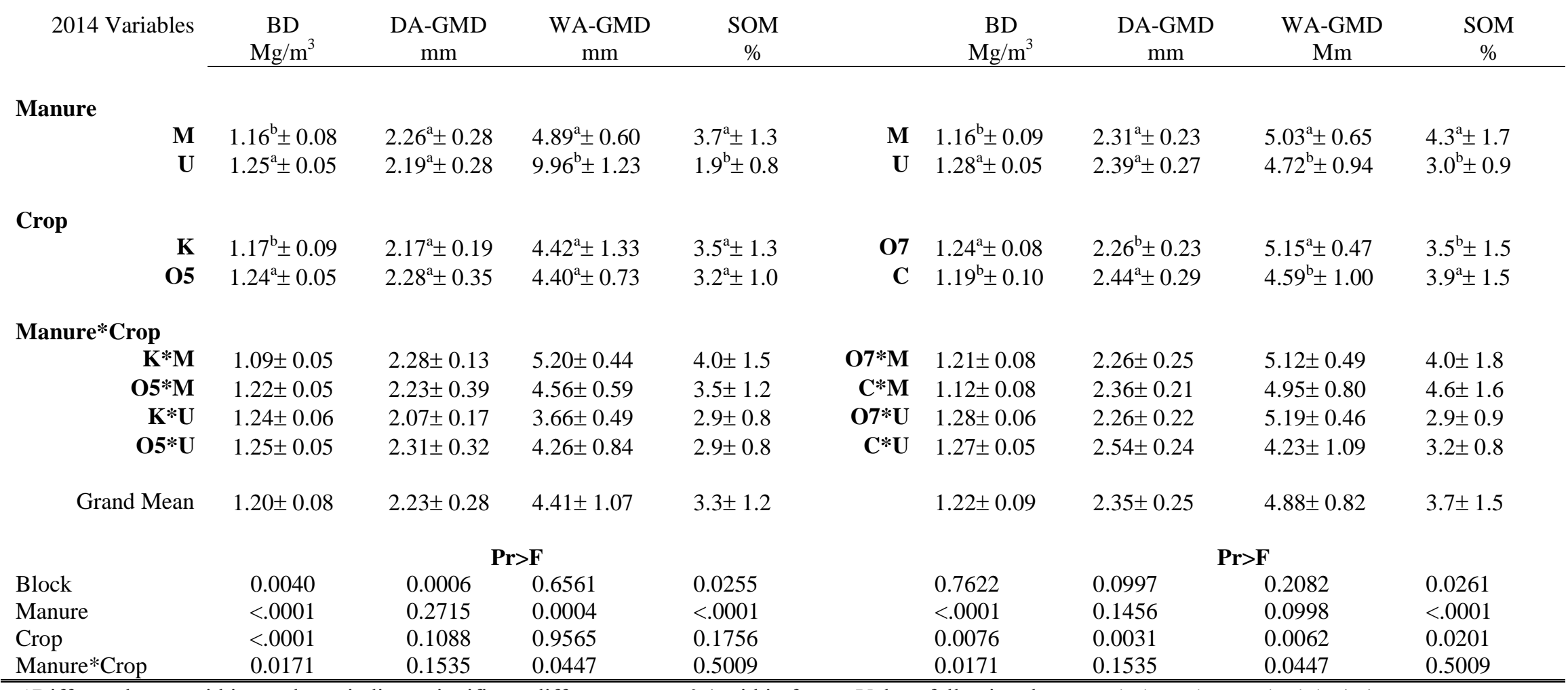

*Different letters within a column indicate significant difference at $\alpha=0.1$ within factor. Values following the \pm symbol are the standard deviation.

$\mathrm{BD}=$ Bulk Density; DA-GMD=Dry aggregate geometric mean diameter; WA-GMD=Wet aggregate geometric mean diameter; SOM $(0-10 \mathrm{~cm})=S o i l$ organic matter; $\mathrm{M}=$ Manured plots; $\mathrm{U}=$ Unmanured plots; $\mathrm{C}=\mathrm{Corn}$; $\mathrm{O}$ = Last year in grass; $\mathrm{K}=\mathrm{Kale}$; $\mathrm{O}$ 5=First year in grass. 
Table 32. Transition from Grass into Crop Component, and Crop into Grass Component: Effect of manure and plant species on 2014 stratified soil $\mathrm{pH}(\mathrm{KCl})$ and soil organic matter $(\mathrm{SOM})$.

\begin{tabular}{|c|c|c|c|c|c|c|c|c|c|}
\hline \multirow[b]{3}{*}{2014 Variables } & \multicolumn{4}{|c|}{ Transition into the grass component } & & \multicolumn{4}{|c|}{ Transition into the crop component } \\
\hline & \multicolumn{2}{|c|}{$\mathrm{pH}(\mathrm{KCl})$} & \multicolumn{2}{|c|}{$\operatorname{SOM}(\%)$} & & \multicolumn{2}{|c|}{$\mathrm{pH}(\mathrm{KCl})$} & \multicolumn{2}{|c|}{$\operatorname{SOM}(\%)$} \\
\hline & $0-5 \mathrm{~cm}$ & $5-10 \mathrm{~cm}$ & $0-5 \mathrm{~cm}$ & $5-10 \mathrm{~cm}$ & & $0-5 \mathrm{~cm}$ & $5-10 \mathrm{~cm}$ & $0-5 \mathrm{~cm}$ & $5-10 \mathrm{~cm}$ \\
\hline \multicolumn{10}{|l|}{ Manure } \\
\hline $\mathbf{M}$ & $6.85^{\mathrm{a}} \pm 0.23$ & $6.84^{\mathrm{a}} \pm 0.30$ & $4.8^{\mathrm{a}} \pm 1.1$ & $4.0^{\mathrm{a}} \pm 0.8$ & $\mathbf{M}$ & $7.21^{\mathrm{a}} \pm 0.21$ & $7.26^{\mathrm{a}} \pm 0.19$ & $6.0^{\mathrm{a}} \pm 1.0$ & $4.5^{\mathrm{a}} \pm 0.9$ \\
\hline $\mathbf{U}$ & $6.44^{\mathrm{b}} \pm 0.46$ & $6.39^{\mathrm{b}} \pm 0.52$ & $3.8^{\mathrm{b}} \pm 0.7$ & $2.9^{\mathrm{b}} \pm 0.6$ & $\mathbf{U}$ & $6.22^{\mathrm{b}} \pm 0.32$ & $6.17^{\mathrm{b}} \pm 0.39$ & $3.9^{\mathrm{b}} \pm 0.6$ & $3.0^{\mathrm{b}} \pm 0.6$ \\
\hline \multicolumn{10}{|l|}{ Crop } \\
\hline $\mathbf{K}$ & $6.65^{\mathrm{a}} \pm 0.42$ & $6.64^{\mathrm{a}} \pm 0.46$ & $4.4^{\mathrm{a}} \pm 1.2$ & $3.6^{\mathrm{a}} \pm 0.9$ & O7 & $6.67^{\mathrm{a}} \pm 0.56$ & $6.71^{\mathrm{a}} \pm 0.63$ & $4.8^{\mathrm{a}} \pm 1.3$ & $3.5^{\mathrm{b}} \pm 1.0$ \\
\hline 05 & $6.64^{\mathrm{a}} \pm 0.42$ & $6.60^{\mathrm{a}} \pm 0.51$ & $4.0^{\mathrm{b}} \pm 0.9$ & $3.4^{\mathrm{a}} \pm 0.8$ & $\mathbf{C}$ & $6.77^{\mathrm{a}} \pm 0.58$ & $6.74^{\mathrm{a}} \pm 0.62$ & $5.1^{\mathrm{a}} \pm 1.4$ & $4.1^{\mathrm{a}} \pm 1.0$ \\
\hline \multicolumn{10}{|l|}{ Manure*Crop } \\
\hline $\mathbf{K} * \mathbf{M}$ & $7.00 \pm 0.20$ & $7.04 \pm 0.22$ & $5.4 \pm 0.9$ & $4.2 \pm 0.8$ & $\mathbf{0 7} * \mathbf{M}$ & $7.12 \pm 0.21$ & $7.23 \pm 0.21$ & $5.8 \pm 1.1$ & $4.1 \pm 1.0$ \\
\hline $05 * M$ & $6.70 \pm 0.14$ & $6.65 \pm 0.24$ & $4.3 \pm 0.9$ & $3.9 \pm 0.8$ & $\mathbf{C} * \mathbf{M}$ & $7.29 \pm 0.19$ & $7.29 \pm 0.18$ & $6.2 \pm 0.7$ & $4.9 \pm 0.8$ \\
\hline $\mathbf{K} * \mathbf{U}$ & $6.29 \pm 0.22$ & $6.24 \pm 0.23$ & $3.5 \pm 0.6$ & $3.0 \pm 0.6$ & $\mathbf{O} 7 * \mathbf{U}$ & $6.21 \pm 0.4$ & $6.19 \pm 0.46$ & $3.8 \pm 0.6$ & $2.8 \pm 0.5$ \\
\hline $\mathbf{0 5} * \mathbf{U}$ & $6.60 \pm 0.59$ & $6.54 \pm 0.68$ & $3.7 \pm 0.8$ & $2.9 \pm 0.6$ & $\mathbf{C} * \mathbf{U}$ & $6.22 \pm 0.21$ & $6.15 \pm 0.31$ & $3.9 \pm 0.7$ & $3.3 \pm 0.5$ \\
\hline Grand Mean & $6.65 \pm 0.42$ & $6.62 \pm 0.48$ & $4.2 \pm 1.1$ & $3.5 \pm 0.9$ & & $6.72 \pm 0.57$ & $6.67 \pm 0.66$ & $4.9 \pm 1.4$ & $3.8 \pm 1.1$ \\
\hline & \multicolumn{4}{|c|}{$\operatorname{Pr}>\mathbf{F}$} & & \multicolumn{4}{|c|}{ Pr $>\mathbf{F}$} \\
\hline Block & 0.8834 & 0.9929 & 0.0798 & 0.0138 & & 0.0016 & 0.0387 & 0.0045 & 0.0160 \\
\hline Manure & $<.0001$ & $<.0001$ & $<.0001$ & $<.0001$ & & $<.0001$ & $<.0001$ & $<.0001$ & $<.0001$ \\
\hline Crop & 0.9940 & 0.6652 & 0.0453 & 0.2717 & & 0.1600 & 0.9355 & 0.1147 & 0.0012 \\
\hline Manure*Crop & 0.0009 & 0.0017 & 0.0039 & 0.3763 & & 0.2035 & 0.5276 & 0.5629 & 0.5181 \\
\hline
\end{tabular}

*Different letters within a column indicate significant difference at $\alpha=0.1$ within factor. Values following the \pm symbol are the standard deviation.

$\mathrm{SOM}=$ Soil organic matter; $\mathrm{M}=$ Manured plots; $\mathrm{U}=$ Unmanured plots; $\mathrm{C}=\mathrm{Corn} ; \mathrm{O} 7=$ Last year in grass; K=Kale; O5=First year in grass. 
Table 33. Transition from Grass into Crop Component, and Crop into Grass Component: Effect of manure and plant species on 2014 stratified soil $\mathrm{P}(\mathrm{mg} / \mathrm{kg})$ and $\mathrm{K}(\mathrm{mg} / \mathrm{kg})$.

Transition into the grass component $\quad$ Transition into the crop component

2014 Variables

$\mathrm{STP}(\mathrm{mg} / \mathrm{kg}) \quad \mathrm{STK}(\mathrm{mg} / \mathrm{kg})$

$5-10 \mathrm{~cm}$ $\mathrm{STP}(\mathrm{mg} / \mathrm{kg})$

$5-10 \mathrm{~cm}$

$0-5 \mathrm{~cm}$ $\mathrm{STK}(\mathrm{mg} / \mathrm{kg})$

Manure

M $\quad 31.1^{\mathrm{a} \pm 16.6} \quad 22.2^{\mathrm{a}} \pm 11.8 \quad 193.6^{\mathrm{a}} \pm 63 \quad 98.7^{\mathrm{a}} \pm 30.4$

$\begin{array}{lllll}\mathbf{U} & 12.3^{\mathrm{b}} \pm 4.4 & 9.3^{\mathrm{a}} \pm 3.7 & 123.3^{\mathrm{b}} \pm 27 & 69.5^{\mathrm{b}} \pm 18.5\end{array}$

M $\quad 93.63^{\mathrm{a}} \pm 26$

U $\quad 11.72^{\mathrm{b}} \pm 7.6$

$60.23^{\mathrm{a}} \pm 26$

$8.00^{\mathrm{b}} \pm 3.9$

$279.1^{\mathrm{a}} \pm 69$

$192.7^{\mathrm{b}} \pm 61$

$198.1^{\mathrm{a}} \pm 64$ $114.1^{\mathrm{b}} \pm 37$

Crop

$\begin{array}{rcccc}\mathbf{K} & 28.3^{\mathrm{a}} \pm 18.6 & 19.6^{\mathrm{a}} \pm 13.1 & 163.7^{\mathrm{a}} \pm 63 & 82.3^{\mathrm{a}} \pm 29.7 \\ \mathbf{O 5} & 15.1^{\mathrm{b}} \pm 6.5 & 11.9^{\mathrm{b}} \pm 5.9 & 153.2^{\mathrm{a}} \pm 57 & 85.9^{\mathrm{a}} \pm 28.7\end{array}$

$\begin{array}{rr}\text { O7 } & 49.60^{\mathrm{a}} \pm 44 \\ \mathbf{C} & 57.28^{\mathrm{a}} \pm 47\end{array}$

$33.13^{\mathrm{a}} \pm 35$ $36.03^{\mathrm{a}} \pm 30$

$205.7^{\mathrm{b}} \pm 66$ $268.6^{\mathrm{a}} \pm 78$

$133.1^{\mathrm{b}} \pm 58$

C $\quad 57.28^{\mathrm{a}} \pm 47$

$59.3 \pm 32.2$

\section{$61.2 \pm 19.5$}

$247 \pm 54.4$

$312 \pm 68.0$

$7.0 \pm 3.2$

$95.3 \pm 32.4$

$\begin{array}{rr}\mathbf{0 5} \mathbf{M} & 18.9 \pm 5.8 \\ \mathbf{K} * \mathbf{U} & 13.2 \pm 3.9\end{array}$

$15.3 \pm 6.0$

$175.5 \pm 69$

$62.5 \pm 12.3$

O5*U $\quad 11.4 \pm 4.8$

$8.5 \pm 3.6$

$130.8 \pm 31$

$76.4 \pm 21.4$

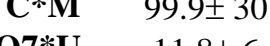

$\begin{array}{rr}\mathbf{O} 7 \mathbf{U} & 11.8 \pm 6.4 \\ \mathbf{C} * \mathbf{U} & 11.6 \pm 8.9\end{array}$

$9.1 \pm 4.5$

$222 \pm 60.1$

$168.6 \pm 56.2$

$227.5 \pm 59.0$

$97.5 \pm 32.7$

Grand Mean

$21.7 \pm 15.3$

$15.8 \pm 10.8$

$158.4 \pm 59$

$84.1 \pm 29.0$

$53.37 \pm 45.4$

$34.56 \pm 32.3$

$236.6 \pm 78.1$

$156.8 \pm 67.1$

\begin{tabular}{|c|c|c|c|c|c|c|c|c|}
\hline \multirow[b]{2}{*}{ Block } & \multicolumn{4}{|c|}{ Pr $>\mathbf{F}$} & \multicolumn{4}{|c|}{$\operatorname{Pr}>F$} \\
\hline & 0.0834 & 0.0746 & 0.0002 & 0.0045 & 0.0016 & 0.0387 & 0.0045 & 0.0160 \\
\hline Manure & $<.0001$ & $<.0001$ & $<.0001$ & $<.0001$ & $<.0001$ & $<.0001$ & $<.0001$ & $<.0001$ \\
\hline Crop & $<.0001$ & 0.0001 & 0.3273 & 0.5553 & 0.1600 & 0.9355 & 0.1147 & 0.0012 \\
\hline Manure*Crop & $<.0001$ & 0.0018 & 0.0198 & 0.0883 & 0.2035 & 0.5276 & 0.5629 & 0.5181 \\
\hline
\end{tabular}

*Different letters within a column indicate significant difference at $\alpha=0.1$ within factor. Values following the \pm symbol are the standard deviation.

$\mathrm{SOM}=$ Soil organic matter; $\mathrm{M}=$ Manured plots; $\mathrm{U}=$ Unmanured plots; $\mathrm{C}=\mathrm{Corn}$; $\mathrm{O} 7=$ Last year in grass; $\mathrm{K}=\mathrm{Kale}$; O5=First year in grass. 
Table 34. Transition from Grass into Crop Component, and Crop into Grass Component: Effect of manure and plant species on 2014 stratified soil $\mathrm{Ca}(\mathrm{mg} / \mathrm{kg})$ and $\mathrm{TotN}(\mathrm{g} / \mathrm{kg})$.

\begin{tabular}{|c|c|c|c|c|c|c|c|c|c|}
\hline \multirow[b]{3}{*}{2014 Variables } & \multicolumn{4}{|c|}{ Transition into the grass component } & & \multicolumn{4}{|c|}{ Transition into the crop component } \\
\hline & \multicolumn{2}{|c|}{$\mathrm{Ca}(\mathrm{mg} / \mathrm{kg})$} & \multicolumn{2}{|c|}{$\operatorname{TotN}(\mathrm{g} / \mathrm{kg})$} & & \multicolumn{2}{|c|}{$\mathrm{Ca}(\mathrm{mg} / \mathrm{kg})$} & \multicolumn{2}{|c|}{$\operatorname{TotN}(\mathrm{g} / \mathrm{kg})$} \\
\hline & $0-5 \mathrm{~cm}$ & $5-10 \mathrm{~cm}$ & $0-5 \mathrm{~cm}$ & $5-10 \mathrm{~cm}$ & & $0-5 \mathrm{~cm}$ & $5-10 \mathrm{~cm}$ & $0-5 \mathrm{~cm}$ & $5-10 \mathrm{~cm}$ \\
\hline \multicolumn{10}{|l|}{ Manure } \\
\hline $\mathbf{M}$ & $1867^{\mathrm{a}} \pm 441$ & $1866^{\mathrm{a}} \pm 427$ & $2.51^{\mathrm{a}} \pm 0.4$ & $2.19^{\mathrm{a}} \pm 0.4$ & $\mathbf{M}$ & $2615^{\mathrm{a}} \pm 538$ & $2472^{\mathrm{a}} \pm 626$ & $3.26^{\mathrm{a}} \pm 0.5$ & $2.53^{\mathrm{a}} \pm 0.5$ \\
\hline $\mathbf{U}$ & $1441^{b} \pm 511$ & $1527^{\mathrm{b}} \pm 778$ & $1.90^{\mathrm{b}} \pm 0.2$ & $1.64^{\mathrm{b}} \pm 0.2$ & $\mathbf{U}$ & $1470^{b} \pm 435$ & $1495^{\mathrm{b}} \pm 455$ & $2.07^{b} \pm 0.2$ & $1.66^{\mathrm{b}} \pm 0.1$ \\
\hline \multicolumn{10}{|l|}{ Crop } \\
\hline $\mathbf{K}$ & $1665^{\mathrm{a}} \pm 486$ & $1638^{\mathrm{a}} \pm 480$ & $2.34^{\mathrm{a}} \pm 0.5$ & $1.99^{\mathrm{a}} \pm 0.4$ & $\mathbf{O} 7$ & $1986^{a} \pm 758$ & $1956^{\mathrm{a}} \pm 756$ & $2.59^{\mathrm{a}} \pm 0.7$ & $1.95^{\mathrm{b}} \pm 0.5$ \\
\hline 05 & $1642^{a} \pm 559$ & $1754^{\mathrm{a}} \pm 781$ & $2.07^{\mathrm{b}} \pm 0.3$ & $1.84^{\mathrm{b}} \pm 0.4$ & C & $2120^{\mathrm{a}} \pm 758$ & $2028^{a} \pm 721$ & $2.76^{\mathrm{a}} \pm 0.7$ & $2.26^{\mathrm{a}} \pm 0.6$ \\
\hline \multicolumn{10}{|l|}{ Manure*Crop } \\
\hline $\mathbf{K} * \mathbf{M}$ & $2061 \pm 295$ & $2027 \pm 277$ & $2.79 \pm 0.39$ & $2.32 \pm 0.37$ & $\mathbf{0 7 * M}$ & $2486 \pm 689$ & $2375 \pm 746$ & $3.10 \pm 0.58$ & $2.29 \pm 0.50$ \\
\hline $05 * M$ & $1672 \pm 485$ & $1706 \pm 497$ & $2.23 \pm 0.28$ & $2.07 \pm 0.33$ & $\mathbf{C} * \mathbf{M}$ & $2745 \pm 301$ & $2569 \pm 486$ & $3.41 \pm 0.37$ & $2.77 \pm 0.46$ \\
\hline $\mathbf{K} * \mathbf{U}$ & $1270 \pm 260$ & $1250 \pm 279$ & $1.88 \pm 0.25$ & $1.67 \pm 0.23$ & $\mathbf{O} 7 * \mathbf{U}$ & $1487 \pm 429$ & $1536 \pm 502$ & $2.09 \pm 0.27$ & $1.60 \pm 0.21$ \\
\hline $05 * \mathbf{U}$ & $1612 \pm 641$ & $1803 \pm 1007$ & $1.91 \pm 0.24$ & $1.62 \pm 0.23$ & $\mathbf{C} * \mathbf{U}$ & $1452 \pm 459$ & $1450 \pm 413$ & $2.05 \pm 0.24$ & $1.72 \pm 0.14$ \\
\hline Grand Mean & $1654 \pm 520$ & $1696 \pm 646$ & $2.20 \pm 0.5$ & $1.92 \pm 0.4$ & & $2052 \pm 755$ & $1991 \pm 734$ & $2.67 \pm 0.7$ & $2.10 \pm 0.6$ \\
\hline & \multicolumn{4}{|c|}{$\operatorname{Pr}>\mathbf{F}$} & & \multicolumn{4}{|c|}{$\operatorname{Pr}>\mathbf{F}$} \\
\hline Block & $<.0001$ & 0.0007 & 0.1262 & 0.0191 & & $<.0001$ & $<.0001$ & 0.0535 & 0.0482 \\
\hline Manure & $<.0001$ & 0.0161 & $<.0001$ & $<.0001$ & & $<.0001$ & $<.0001$ & $<.0001$ & $<.0001$ \\
\hline Crop & 0.8103 & 0.3987 & 0.0007 & 0.0440 & & 0.2437 & 0.6796 & 0.1678 & 0.0024 \\
\hline Manure*Crop & 0.0004 & 0.0023 & 0.0003 & 0.2043 & & 0.0871 & 0.1690 & 0.0740 & 0.0557 \\
\hline
\end{tabular}

*Different letters within a column indicate significant difference at $\alpha=0.1$ within factor. Values following the \pm symbol are the standard deviation.

$\mathrm{SOM}=$ Soil organic matter; $\mathrm{M}=$ Manured plots; $\mathrm{U}=$ Unmanured plots; $\mathrm{C}=\mathrm{Corn} ; \mathrm{O} 7=$ Last year in grass; $\mathrm{K}=\mathrm{Kale}$; O5=First year in grass. 
Table 35. Effect of manure treatment and year into the transition on grass biomass in 2013 and 2014.

\begin{tabular}{|c|c|c|c|}
\hline \multirow[t]{2}{*}{ Variables } & & Grass 2013 & $\overline{~ G r a s s ~} 2014$ \\
\hline & & \multicolumn{2}{|c|}{$\mathrm{Mg} \mathrm{ha}^{-1}$} \\
\hline vianure & $\begin{array}{l}\mathrm{M} \\
\mathrm{U}\end{array}$ & $\begin{array}{l}4.99^{\mathrm{a}} \pm 1.27 \\
3.26^{\mathrm{b}} \pm 1.23\end{array}$ & $\begin{array}{l}6.84^{\mathrm{a}} \pm 0.70 \\
5.49^{\mathrm{a}} \pm 1.65\end{array}$ \\
\hline
\end{tabular}

Year (in pasture)
$\mathrm{O} 5=1-\mathrm{yr}$
$3.78^{\mathrm{a}} \pm 1.40$
$6.69^{\mathrm{a}} \pm 1.49$
$\mathrm{O} 6=2-\mathrm{yr}$
$3.78^{\mathrm{a}} \pm 1.79$
$6.43^{\mathrm{a}} \pm 0.84$
$\mathrm{O} 7=3-\mathrm{yr}$
$4.81^{\mathrm{a}} \pm 1.31$
$5.37^{\mathrm{a}} \pm 1.64$

\section{Manure*Year}

$\begin{array}{rll}\text { M x O5 } & 4.36 \pm 1.60 & 6.81 \pm 0.98 \\ \text { M xO6 } & 5.09 \pm 1.68 & 6.87 \pm 0.97 \\ \text { M x O7 } & 5.51 \pm 1.29 & 6.85 \pm 0.17 \\ \text { Ux O5 } & 3.19 \pm 1.13 & 6.58 \pm 2.13 \\ \text { Ux O6 } & 2.48 \pm 0.29 & 5.99 \pm 0.51 \\ \text { Ux O7 } & 4.10 \pm 1.66 & 3.89 \pm 0.36 \\ & & \\ \text { nd Mean } & 4.36 \pm 1.60 & 6.70 \pm 1.49\end{array}$

Grand Mean

$.36 \pm 1.60$

Block

0.8193

Pr $>$ F

$6.70 \pm 1.49$

Manure

0.0219

0.7779

0.3546

0.0303

Year (in pasture)

0.6291

0.1533

0.1466

*Different letters within a column indicate significant difference at $\alpha=0.1$ within factor. Values following the \pm symbol are the standard deviation. $\mathrm{M}=$ Manured plots; $\mathrm{U}=$ Unmanured plots; $\mathrm{O} 5=$ First year in grass $\mathrm{O} 7=$ Last year in grass; $\mathrm{K}=$ Kale; $\mathrm{C}=$ Corn.

\section{DISCUSSION}

\section{Within Rotation Effect of Manure and Crop on Physical and Chemical Quality Manure effect within rotation type (4-yr and 7-yr)}

In 2013, surface bulk density values were statistically significantly affected by composted manure addition regardless of rotation. Manure addition has been found to decrease bulk density by others (Hati et al., 2007, Schjonning et al, 1994). This effect may be due to the incorporation of a less-dense material into the soil (lowering overall density), the improvement in aggregation associated with increased SOM and the subsequent increase in micropore volume, or possible increased root growth in manured plots (Schjonning et al., 1994). 
Within rotation, in 2013, dry aggregate stability (GMD) values were significantly larger in crops planted in the 4-yr rotational cycle not receiving composted manure. No significant difference was observed between manured and unmanured plots in the 7-yr cycle. The grass component in the 7-yr rotation may have modified the effect of manure on GMD by increasing dry aggregation via root mass. In the 7 -yr rotation, regardless of manure application, in the corn plots the grass component may have left larger residual aggregates due to grass roots holding particles and secondary aggregates together (Tisdall \& Oades, 1979; Chan \& Heenan, 1996).

Wet aggregate stability-geometric mean diameter (WA-GMD) values were significantly larger in plots in the 4-yr rotation receiving composted manure, as compared to 4-yr plots not receiving composted manure. Several scientists have reported the benefits of organic matter on water-stable aggregation (Six et al., 2001; Bird et al., 2002; Shirani et al., 2002). No significant difference was observed between manured and unmanured plots in the 7-yr rotation; this showed evidence of the possible effect that the grass component may have on wet aggregation, which was a similar effect to that of the manure application. Increased SOM is known to correlate with increased aggregate stability (Green et al., 2005; Rachman et al., 2003).

In both rotations, plots receiving composted manure had significantly higher SOM than plots receiving no composted manure. The increase in SOM is a direct effect of manure application (Bronick \& Lal, 2005; Hati et al., 2007; Luo et al., 2009). The first crop (corn), received direct manure application, while the last crop (kale) did not.

In the 4-yr rotation cycle soil $\mathrm{pH}$ values were significantly affected by composted manure addition at all depths (Table 4). In all cases, soil $\mathrm{pH}$ was higher in manured plots than in unmanured plots. The effect of $\mathrm{pH}$ increase with the addition of manure has been observed by other scientists (Whalen et al., 2000; Walker et al., 2004; Haynes \& Naidu, 1998; Eghball, 2002). The fact that $\mathrm{pH}$ was only significantly affected in the 4-yr rotation, and not in the 7-yr may be due to a higher absolute manure quantity applied to the 4-yr plots than to the 7-yr plots; therefore the effect of manure on $\mathrm{pH}$ is more evident in 4-yr plots.

Soil Organic Matter (SOM) is the direct consequence of manure application, and rotation composition and duration. Results support the significant relationship between applied manure and soil organic matter at all depths regardless of rotation type or crop (corn and kale). As manure was applied, SOM increased (Tables 5 and 6). Manure is also a direct source of plant 
available nutrients. All measured nutrients responded positively to manure addition. As their behavior was so similar, they will be discussed together.

Within the 4-yr and 7-yr rotations, all nutrients responded positively to manure application. Zinc $(\mathrm{Zn})$ is considered a micronutrient in the soil, and is needed in small but critical bioavailable concentrations. Livestock manures are sources of $\mathrm{Zn}$ applied to the soil as fertilizers or amendments (Alloway, 2008). In this rotation study, the manure treatment applied to the rotation was expected to affect the natural background soil test zinc (STZn). As was found for soil organic matter (SOM) and STZn, changes in soil total nitrogen (TotN) were expected to directly respond to the manure treatment applied in this study.

\section{Crop effect within rotation type (4-yr and 7-yr)}

No significant effect of crop was observed on bulk density in either rotational cycle. This issue is uncommon in the literature, but because of similar tillage and planting practices, no significant difference is expected between $\mathrm{BD}$ values in corn and kale plots.

Dry aggregate stability (DA-GMD) was significantly higher in 7-yr corn plots than in 7yr kale plots. A possible explanation for this is that tillage activity during the cropping cycle results in smaller dry-stable aggregates by the end of the cropping cycle. It is interesting that there is no significant effect of crop in the 4-yr plots, which indicates that either the DA-GMD is smaller to begin with in corn plots, or there is less of a decrease in size due to the cropping cycle.

Wet aggregate stability was significantly higher in the 7-year rotation cycle corn plots than in 7-yr kale plots. It is possible that the observed benefit of the grass component was lost after three years of continuous cropping. In comparison to the 7 -yr rotation, no significant effect of crop was observed in the 4-year plots. As found for DA-GMD, it appears that in the 4-yr rotation, WA-GMD was never large enough in the first place to experience a significant decrease in size over time in the cropping cycle.

It was observed that regardless of rotation, corn plots show a higher SOM content than kale plots. As was explained in the previous soil physical properties section, manure application schedule may explain this observation.

A significant effect of crop was only found on $\mathrm{pH}$ at the surface $(0-5 \mathrm{~cm})$ in the 7 -yr corn plots; the measured $\mathrm{pH}$ was higher in the corn plots than in the kale plots. The significant 
decrease in surface $\mathrm{pH}$ three years after the first crop (corn) observed in the 7-yr rotation but not in the 4-yr rotation is evidence of the loss of the effect of the grass component after cropping.

Within rotation, the effect of crop is significant on many nutrients; values in corn plots are significantly higher than those in kale plots.

A significant effect of crop was found on STMg at the $0-5 \mathrm{~cm}$ depth in the 7-yr plots (Table 7). In this case, STMg values were higher in corn plots than in kale plots. This observation could be a consequence of the higher, recent and more frequent application of manure in the 4-yr cycle. However, STMg $(0-10 \mathrm{~cm})$ for corn plots and STMg $(0-5 \mathrm{~cm})$ for kale plots is only significantly different in kale plots at the $5-10 \mathrm{~cm}$ depth.

Regardless of rotation, corn plots exhibited statistically significant higher STZn and TotN than kale (Table 7); this observation is explained by timing of the manure application.

\section{Interactions within rotation type (4-yr and 7-yr) between manure and crop}

A highly significant interaction between manure and crop on bulk density values was observed in the 4-yr rotation: the effect of manure on corn was higher than on kale (Figure 5). This may be explained by the fact that corn received composted manure directly at planting time, while kale did not. It is interesting to observe that in the 7-yr rotation, no interaction was observed between manure application and crop, indicating that the grass component may have improved the soil bulk density in a way that it was able to override the manure effect during the crop component of the rotation.

As was found for $\mathrm{BD}$, a significant interaction between manure and crop was observed for DA-GMD in 7-yr plots, but not in 4-yr plots (Figure 6). The effect of manure application resulted in a higher DA-GMD in the 7-yr rotation regardless of crop, however the difference between manured and unmanured plots was smaller for corn than for kale. The grass component increased the DA-GMD regardless of manure application; this may be due to the physical and biochemical effect of the grass. No interaction was observed for wet aggregate stability (WAGMD). 

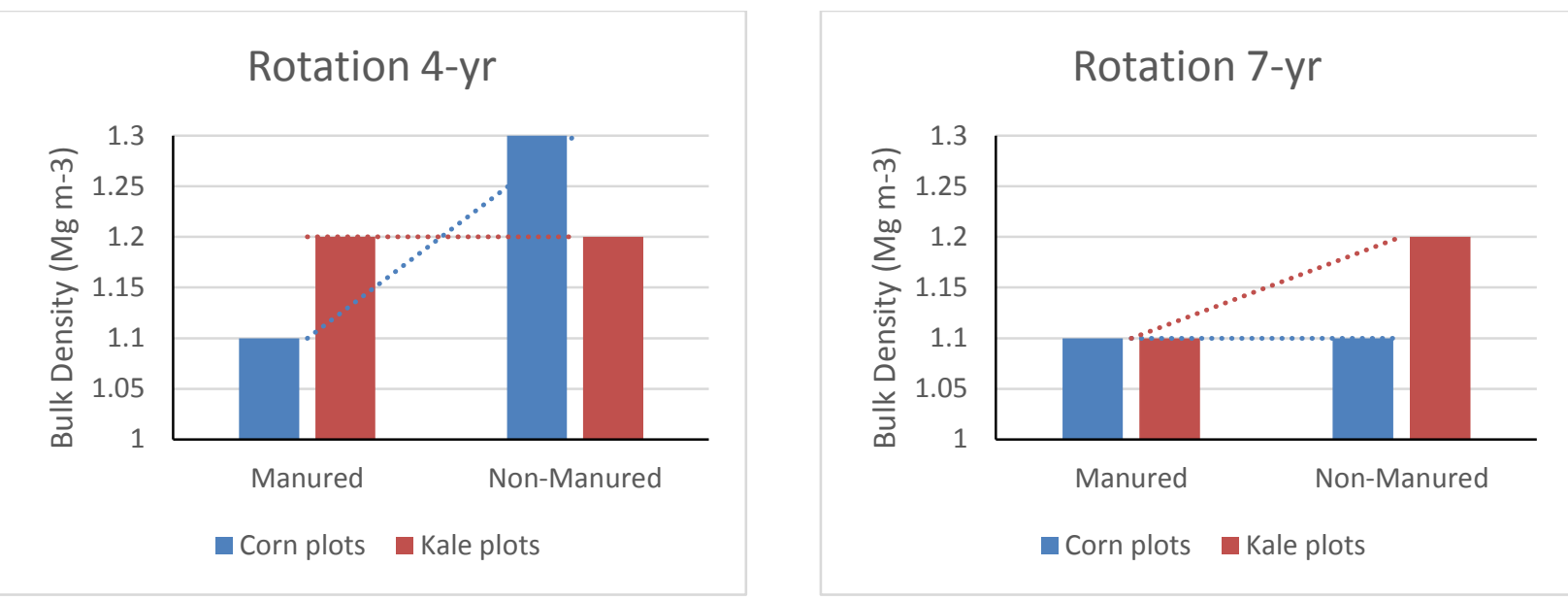

Figure 5. Interactions for bulk density (BD, 0-5mm) between manured and unmanured plots within rotation.
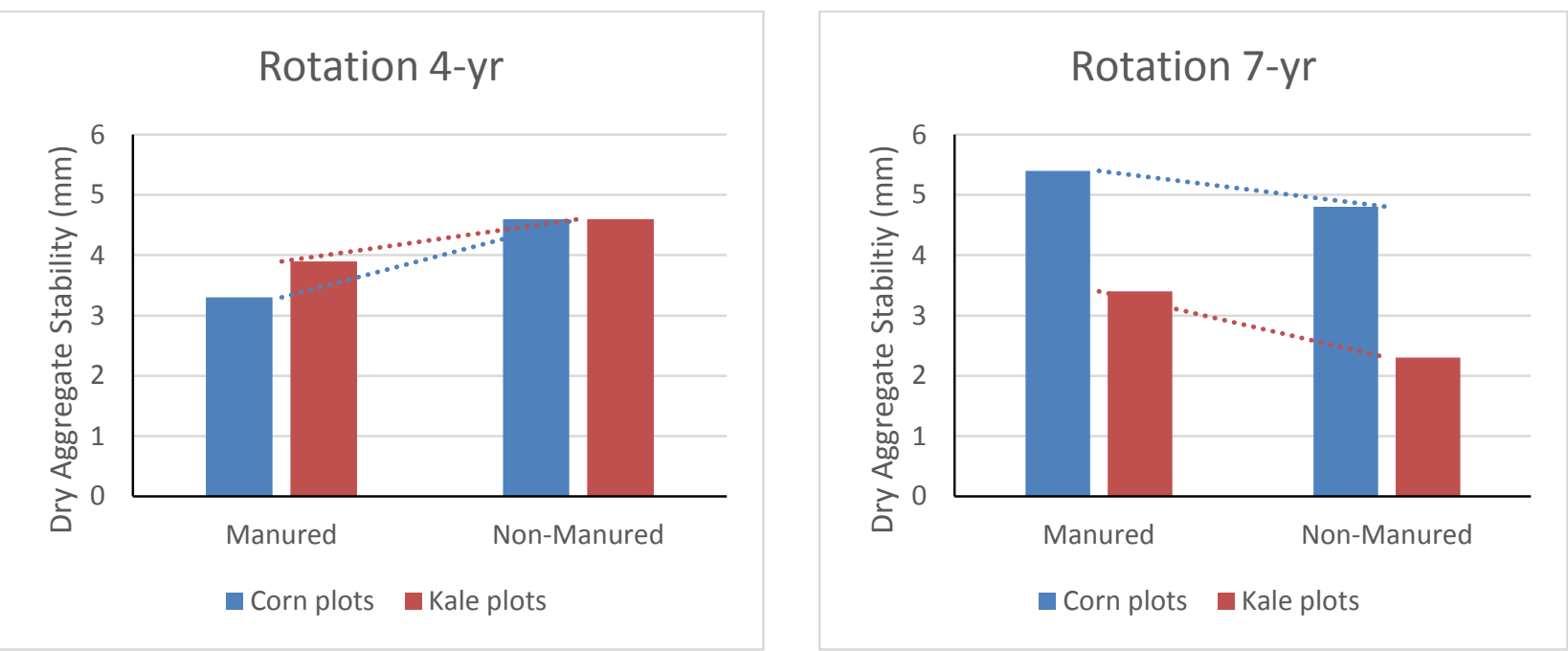

Figure 6. Interactions for dry aggregate stability geometric mean diameter (DA-GMD, 0-5cm) between manured and unmanured plots within rotation.

In the 4-yr rotation, at all depths the magnitude of the difference between SOM in the manured and unmanured corn plots was higher than that observed for the kale plots (Figure 7). In other words, regardless of crop, the decrease in SOM when manure was not applied was much larger in the corn plots than in the kale plots. Considering that manured corn plots were directly manured every year, and kale was not, this result is to be expected. The fact that this interaction was not observed in the 7-yr rotation may be the result of the grass component. 

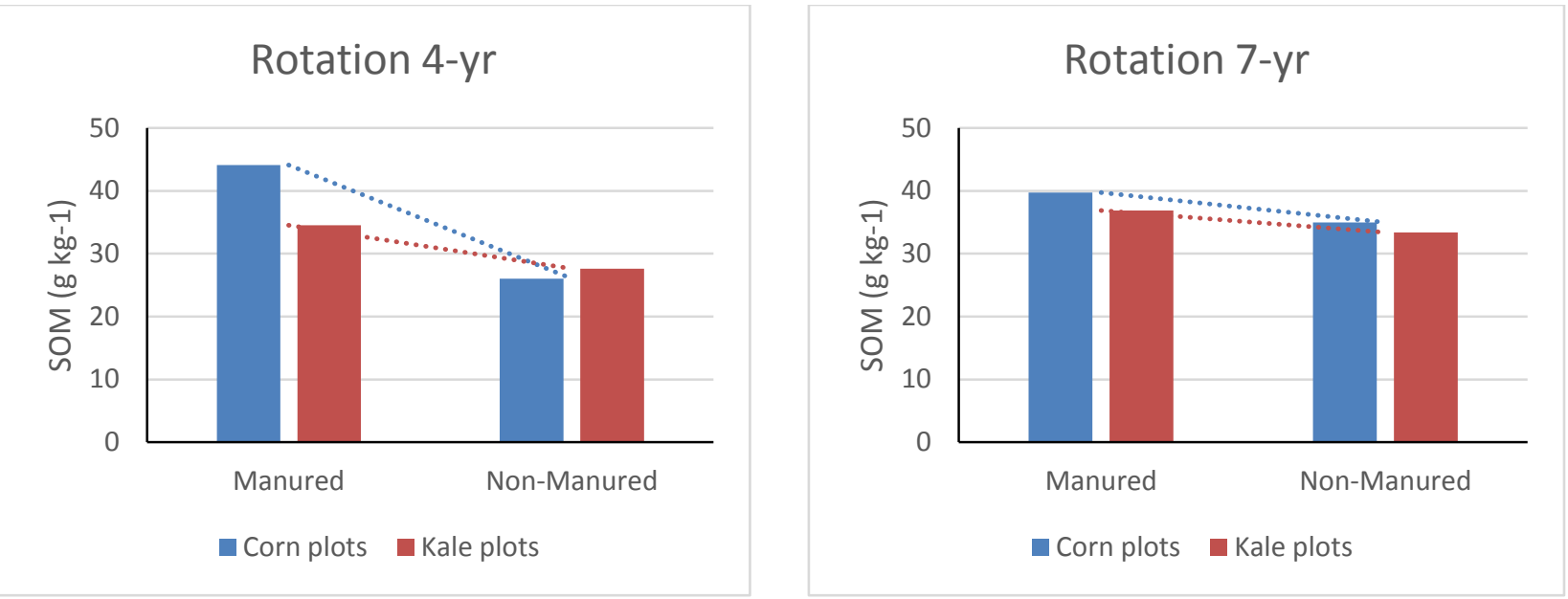

Figure 7. Interactions for soil organic matter (SOM, 0-5 $\mathrm{cm})$ between manured and unmanured plots within rotation.

For $\mathrm{pH}$, an interaction was observed between manure and crop in $4-\mathrm{yr}$ plots at the $0-10 \mathrm{~cm}$ depth, but not in the 7-yr plots (Figure 8). In the 4-yr rotation the interaction shows that although $\mathrm{pH}$ is always lower in unmanured plots, corn plots have a bigger difference in $\mathrm{pH}$ than the kale plots. This may be due to the manure application schedule in which manure is applied to the first (corn) and third (wheat) crop of the rotation, kale does not receive manure directly. Stratified soil organic matter interactions are similar to those already discussed.
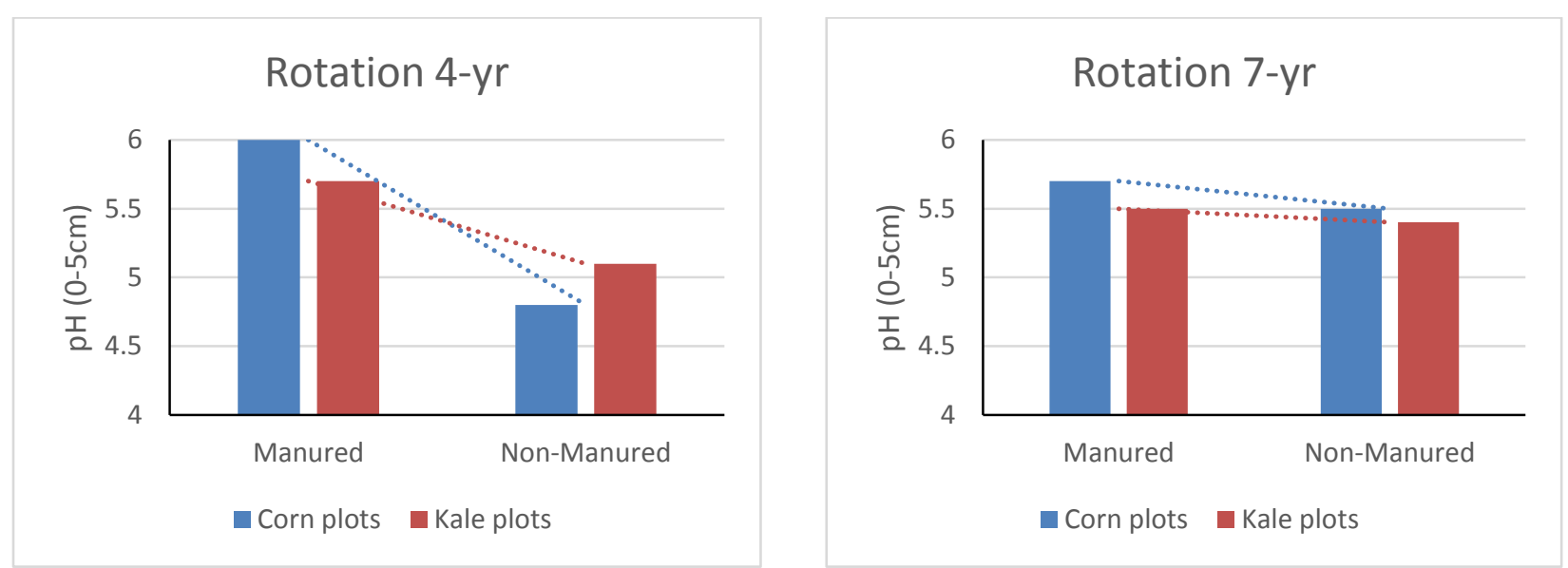

Figure 8. Interactions for $\mathrm{pH}(0-5 \mathrm{~cm})$ between manured and unmanured plots within rotation.

Soil test phosphorus (STP) showed an interaction between manure and crop (Figure 9). At the $0-5 \mathrm{~cm}$ and $5-10 \mathrm{~cm}$ depth, a decrease was observed from corn to kale plots, but in the 4-yr rotation unmanured corn plots had much lower values than 7 -yr corn plots. Therefore more of a 
decrease occurred in the 7-yr plots from corn to kale in non-manured plots than in 4-yr unmanured plots. This appears to show a beneficial effect of the 7-yr rotation on corn plots in the absence of composted manure application. Soil test potassium (STK) behavior was very similar to that of STP (Figure 10).
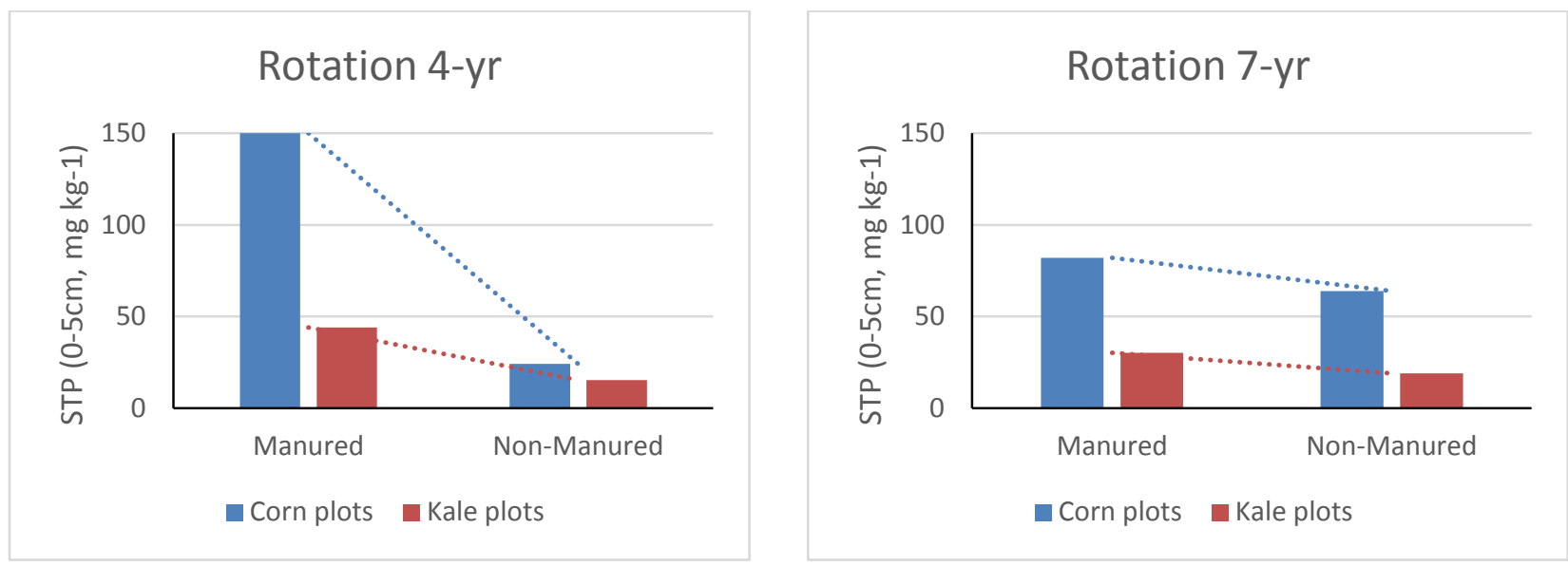

Figure 9. Interactions for soil test Phosphorus $(\mathrm{STP}, 0-5 \mathrm{~cm})$ between manured and unmanured plots within rotation.
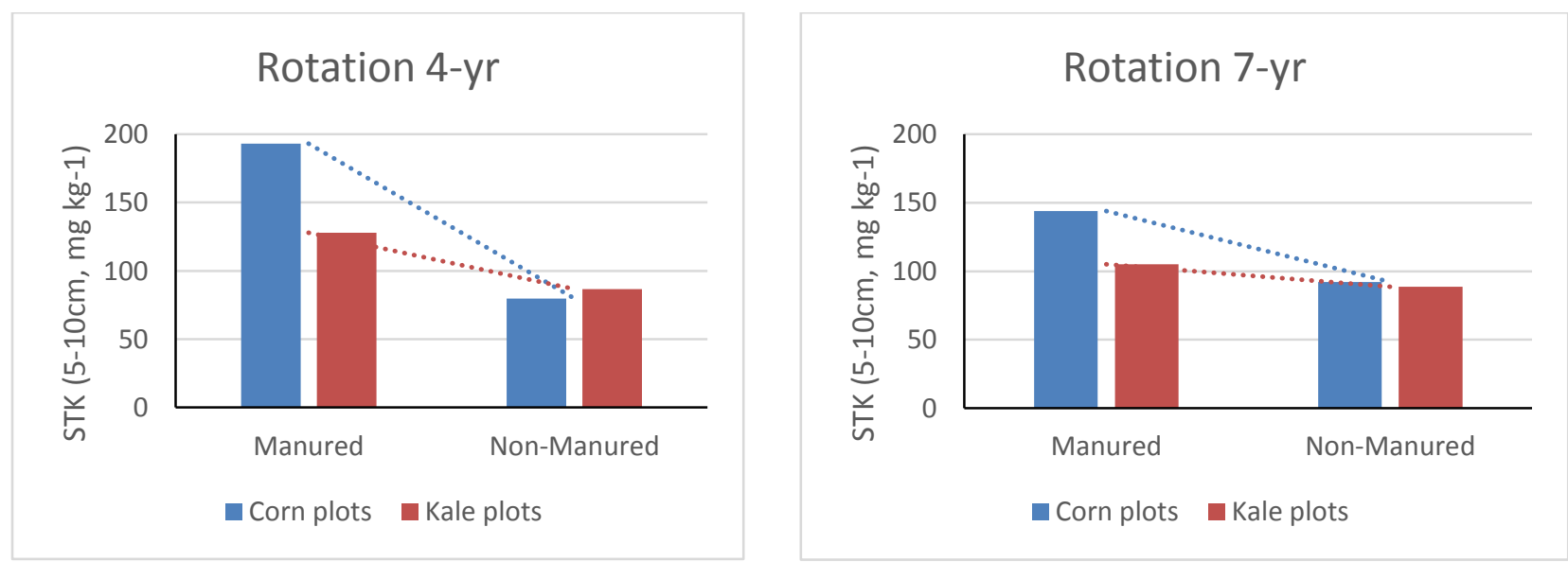

Figure 10. Interactions for soil test potassium $(\mathrm{STK}, 5-10 \mathrm{~cm})$ between manured and unmanured plots within rotation.

For soil test calcium (STCa), an interaction was found for the 4-yr rotation; however the interaction was only observed for the $7-y$ r rotation at the $5-10 \mathrm{~cm}$ depth (Figure 11). The behavior of the interaction in the 7-yr rotation is the same as observed for STK. Data indicate that STCa values in the 4-yr unmanured corn plots responded differently than the 4-yr unmanured kale plots. The interaction behavior of soil test $\mathrm{Mg}$ is the opposite of what is observed for the previous nutrients (Figure 12,13). It is possible that there is mobilization of STMg in the grass 

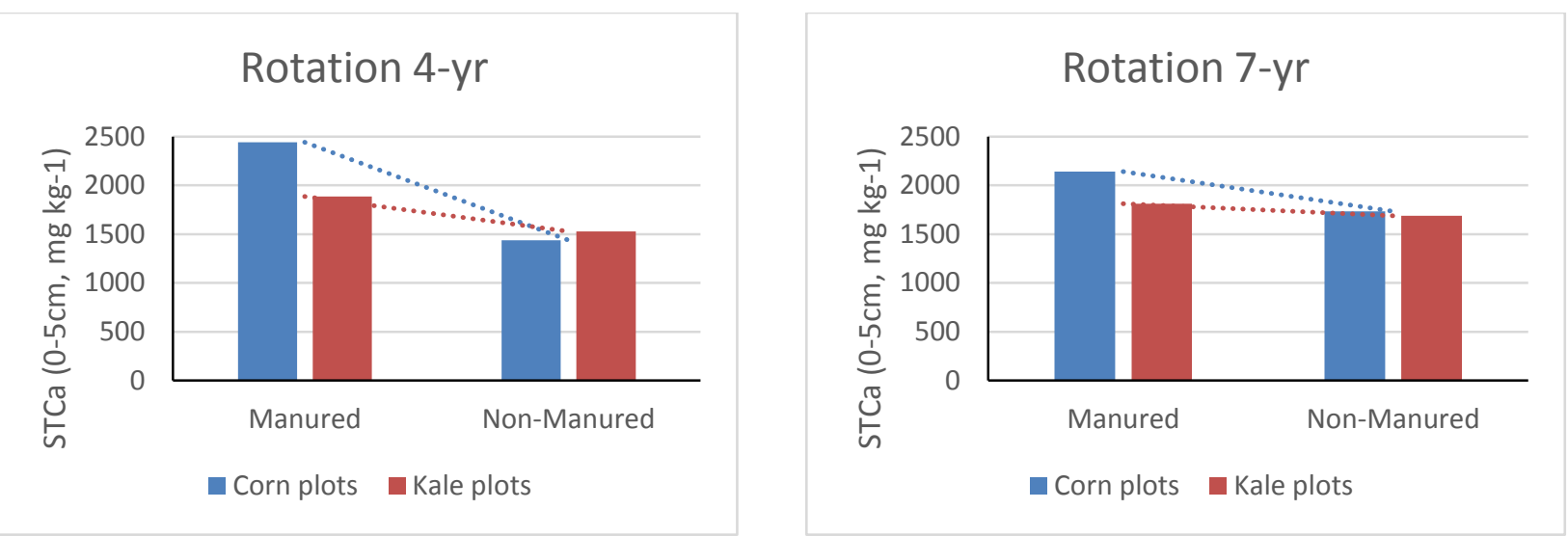

Figure 11. Interactions for soil test calcium (STCa, $0-5 \mathrm{~cm}$ ) between manured and unmanured plots within rotation.

component, leaving higher levels of STMg in the soil, but the kale crop either does not appear to remove very much from the soil, or what it removes is returned to the soil in crop residues.
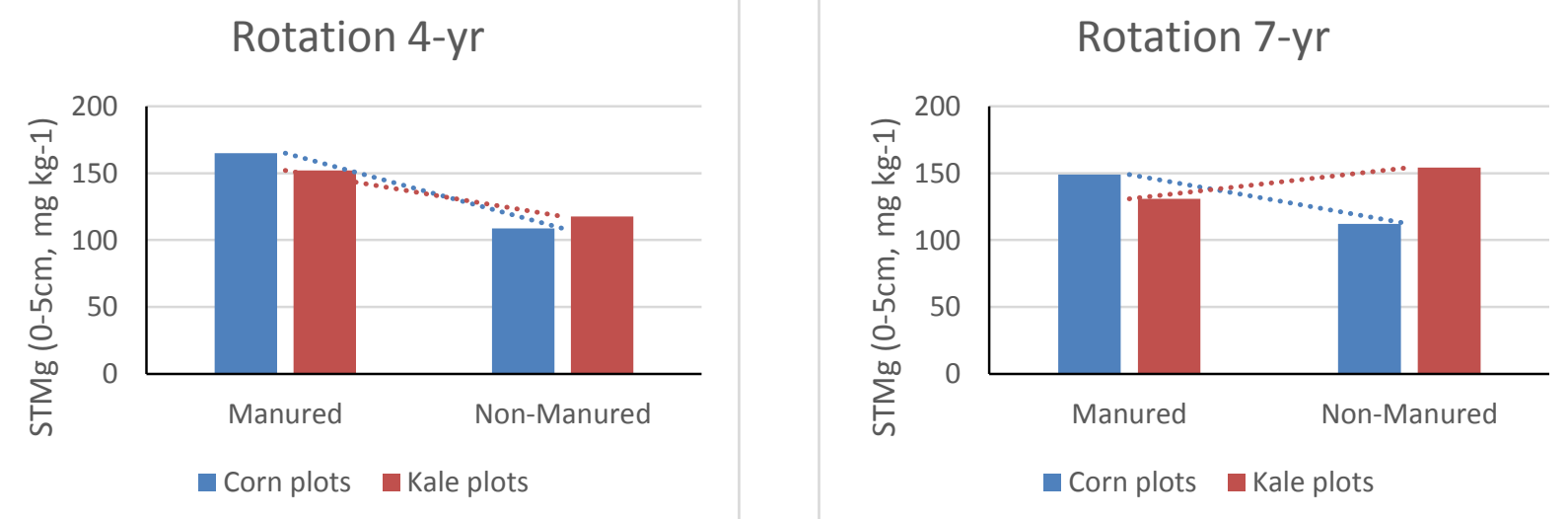

Figure 12. Interactions for soil test magnesium $(\mathrm{STMg}, 0-5 \mathrm{~cm})$ between manured and unmanured plots within rotation.
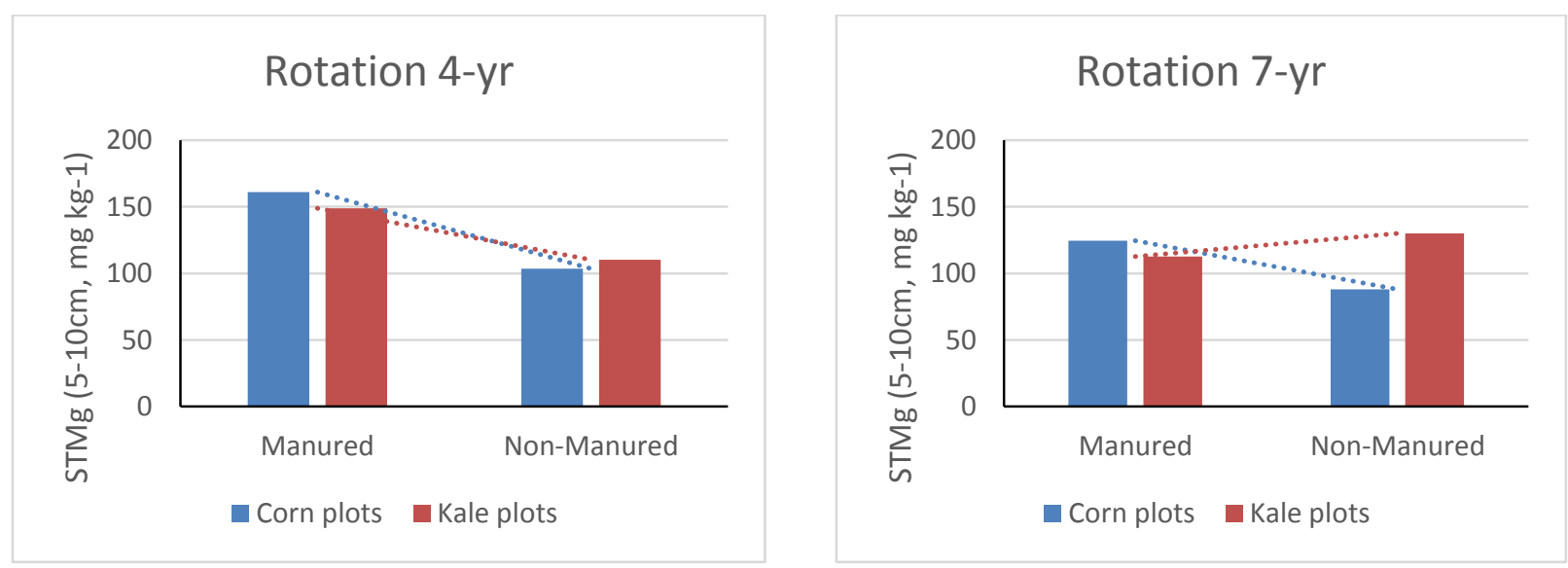

Figure 13. Interactions for soil test magnesium $(\mathrm{STMg}, 5-10 \mathrm{~cm})$ between manured and unmanured plots within rotation. 
The 4-yr rotation shows a high-magnitude interaction effect of crop and manure on measured zinc and nitrogen; at all depths unmanured corn and kale plots had a similar TotN and STZn, but significant differences were observed when the corn and kale plots were manured (Figure 14, 15). Manure application timing explains this observation. No interactions were observed for either STZn or TotN for the 7-yr rotation, regardless of crop. The interaction observed for surface TotN (0-5cm) exhibits the same behavior as STZn (Table 16).
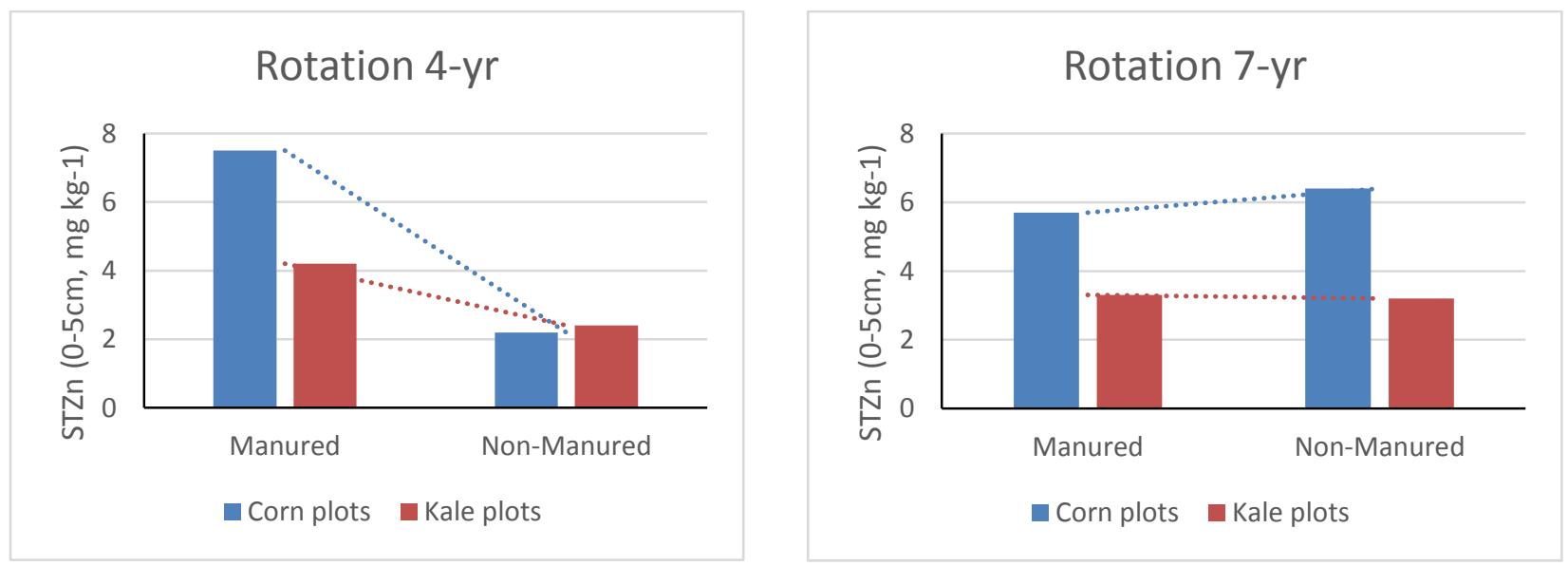

Figure 14. Interactions for soil test zinc $(\mathrm{STZn}, 0-5 \mathrm{~cm})$ between manured and unmanured plots within rotation.
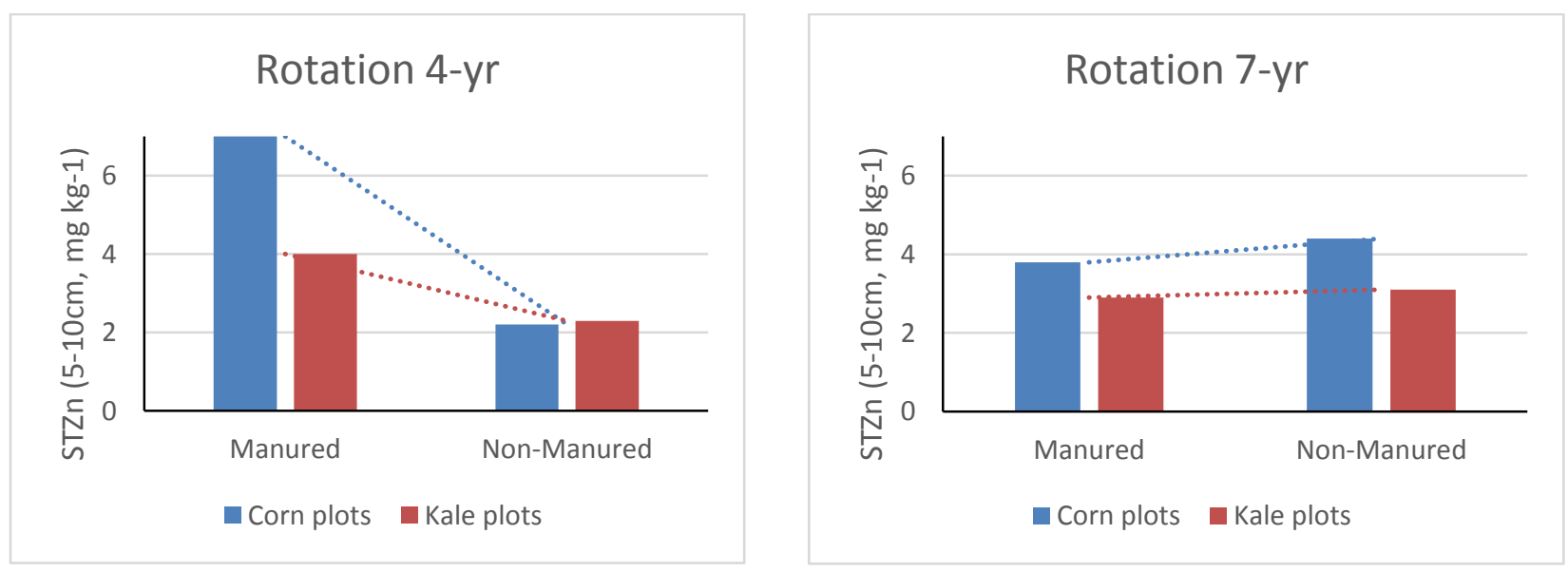

Figure 15. Interactions for soil test zinc $(\mathrm{STZn}, 5-10 \mathrm{~cm})$ between manured and unmanured plots within rotation. 

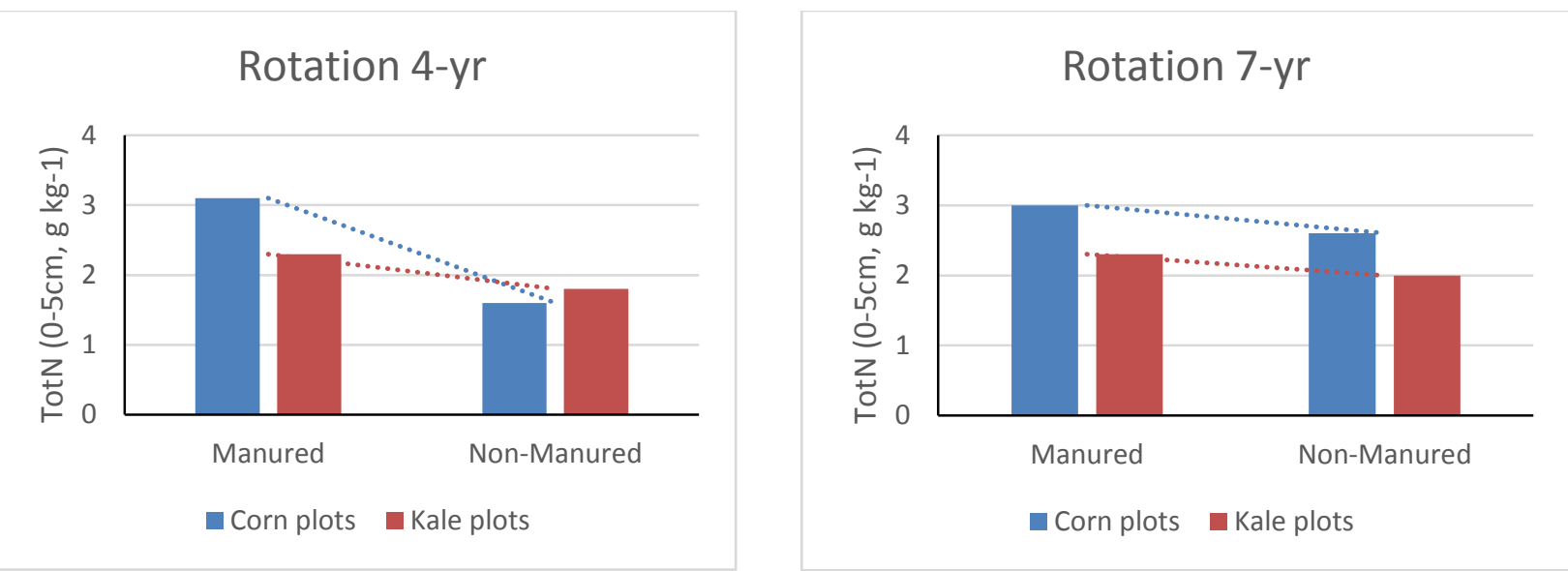

Figure 16. Interactions for total nitrogen (TotN, $0-5 \mathrm{~cm}$ ) between manured and unmanured plots within rotation.

\section{Between-Rotation Effect of Manure and Rotation on Physical and Chemical Quality, and Biomass}

\section{Manure effect between rotation type (4yr and 7-yr)}

In 2013, when comparing surface BD within crop in the 4-yr rotation against the 7-yr rotation, BD values were significantly affected by manure addition in the first crop of the rotation (corn) and in the last crop of the rotation (kale). In both crops, plots receiving composted manure exhibited significantly lower bulk density than plots receiving no composted manure.

In 2013, when comparing the same crop between rotations, dry aggregate stability (DAGMD) values were significantly larger in kale plots not receiving composted manure than those receiving composted manure, regardless of rotation type. No significant difference was observed between manured and unmanured corn plots (Figure 18). Results indicate that under the kale plots larger blocks of soil with low porosity were formed due to tillage and low organic matter after three years of continuous cropping. A higher bulk density in these plots supports this explanation.

Regardless of crop, wet aggregate stability (WA-GMD) was greater in plots receiving composted manure than in plots receiving no manure. Soil organic matter (SOM) values were significantly higher in corn and kale plots receiving composted manure ("Manured") than "Unmanured" plots (Table 8). 
Soil $\mathrm{pH}$ values between $0-10 \mathrm{~cm}$ in depth were significantly affected by composted manure addition regardless of temporal position in the rotation (first or last crop) (Table 9). In all cases, soil $\mathrm{pH}$ was higher in manured plots than in unmanured plots; the proposed explanation for this observation was given in previous paragraphs.

In general, soil fertility in this rotation experiment was managed using manure applications. Nutrients such as phosphorus $(\mathrm{P})$ and nitrogen $(\mathrm{N})$ in organic systems are commonly managed through manure application, however there are other elements such as calcium $(\mathrm{Ca})$, magnesium $(\mathrm{Mg})$, potassium $(\mathrm{K})$, zinc $(\mathrm{Zn})$ that are part of the manure composition. As a consequence $\mathrm{P}, \mathrm{K}, \mathrm{Ca}, \mathrm{Mg}, \mathrm{K}, \mathrm{Zn}$, and $\mathrm{N}$ are expected to be highly related to manure applied. In general, higher manure applications were found to be associated with significant increases in nutrient content.

Cowpea biomass and total biomass (weeds + cowpeas) were significantly affected by manure application (Table 14). Biomass was significantly higher in manured plots, however weed biomass was not affected by manure. In 2013 , over $50 \%$ of the total biomass sampled was weed biomass (Table 14).

Several problems with biomass sampling prevented the intended comparisons from being made in this study. Inconsistent weed-management and very poor plant stand in 2013 corn plots prevented accurate biomass data collection for these plots. These data have been omitted.

\section{Rotation effect between rotation type (4yr and 7-yr)}

A significant effect of rotation cycle on bulk density was observed in the corn plots, but not in kale plots. Corn plots in the 7-yr cycle had significantly lower bulk density than corn plots in the 4-yr cycle (Table 8). In 2013, dry aggregate stability was significantly higher in the 7-year rotation corn plots, compared to the 4-year corn plots. No significant effect of rotation cycle on DA-GMD was observed in kale plots. Rotation had a statistically significant effect on wet aggregate stability for corn and kale plots. Wet aggregate stability was significantly higher in the 7-year rotation cycle corn plots, while the opposite was true for kale plots (Table 8). This may be due to a residual effect of roots from the grass component causing larger aggregates in plots immediately following this treatment, which are then tilled and broken down by the end of the 
cropping cycle and compensated for by the greater absolute amount of manure present in the 4-yr rotation.

A significant effect of rotation cycle on SOM (0-10cm depth) was observed in the kale plots, but not in corn plots. Kale plots in the 7-yr cycle had significantly higher SOM than kale plots in the 4-yr cycle.

For $\mathrm{pH}$, a significant effect of rotation was only observed in the surface depth $(0-5 \mathrm{~cm})$ in corn, indicating that on average the soil $\mathrm{pH}$ was significantly higher in $7-\mathrm{yr}$ plots $(\mathrm{pH}=5.6)$ than in the 4-yr plots $(\mathrm{pH}=5.4)$. When comparing stratified SOM between the first and last crop of the rotation, a significant effect of rotation was observed at the $0-5 \mathrm{~cm}$ depth for the corn plots, and at all depths for kale. Soil test phosphorus $(0-10 \mathrm{~cm}$ depth) was statistically significantly higher in the 4-yr rotation than in the 7-yr rotation (Table 10$)$. Soil test potassium $(5-10 \mathrm{~cm})$ was also is statistically significantly higher in the $4-y r$ rotation than in the $7-y$ r rotation. This observation could be a consequence of the higher, recent and more frequent application of manure in the 4-yr cycle. However, STK for corn plots $(0-10 \mathrm{~cm})$ and for kale plots $(0-5 \mathrm{~cm})$ does not show significant differences between rotations.

A significant effect of rotation was only observed at the $5-10 \mathrm{~cm}$ depth in corn plots for soil test calcium (STCa) (Table 11). Soil test calcium was statistically significantly higher in the 4-yr plots than in the 7-yr plots. This may be due to the more recent and more often application of manure in the 4-yr cycle. A significant effect of rotation on STMg was observed regardless of crop, but only at the $0-5 \mathrm{~cm}$ depth. In both cases, 7-yr STMg values were higher than those in the 4-yr rotation. There was no significant effect of rotation on STZn $(0-10 \mathrm{~cm})$ and $\mathrm{TotN}(5-10 \mathrm{~cm})$ in corn or kale. There was a significant effect of rotation on TotN $0-5 \mathrm{~cm}$ regardless of being the first or last crop of the cropping sequence, in both cases the 7-yr rotation exhibited higher nitrogen concentration than the 4-yr rotation; grass root incorporation may explain the higher $\mathrm{N}$ at the soil surface.

Cowpea biomass, weed biomass, and total biomass (weeds + cowpeas) were not significantly affected by rotation (Table 14). 


\section{Interactions between manure and rotation, between rotation type (4yr and 7-yr)}

A highly significant interaction was found between manure and rotation only for corn; the effect of not applying manure resulted in a higher BD in the 4-yr rotation than in the 7-yr rotation (Figure 17). The grass component in the 7-yr rotation without manure application may have protected the soil $\mathrm{BD}$, by means of increasing the porosity with incorporated grass residues and roots, and by the fact that the grass component plots are not tilled (Bhattacharyya et al., 2006). In the kale crop regardless of rotation type, the grass component effect may not remain after three years of cropping, and an increase in BD was observed when manure was not applied.
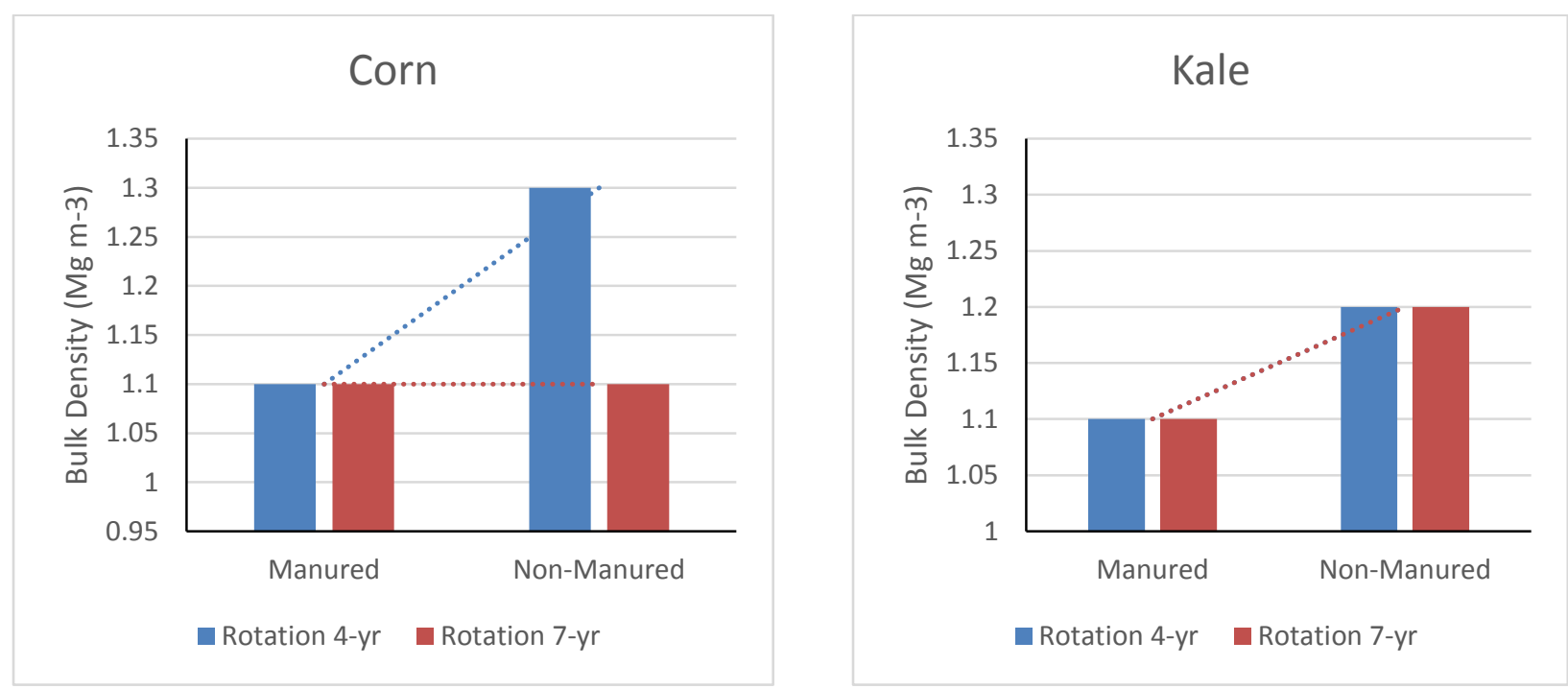

Figure 17. Interactions for bulk density $(\mathrm{BD}, 0-5 \mathrm{~cm})$ between manure and rotation between rotations (4-yr and 7-yr).

The interaction observed for dry aggregate stability (DA-GMD) between manure and rotation in corn plots but not in kale plots is similar to the description for bulk density. The slight decrease in DA-GMD in the 7-yr rotation may indicate that the grass component increased the strength of aggregates to be broken when dry, regardless of manure application.

An interaction was observed for WA-GMD between manure and rotation in corn plots, but not in kale plots. For corn, although the WA-GMD decreased as manure rate decreased regardless of rotation, in the 7-yr rotation the decrease was insignificant $(5.0 \mathrm{~mm}$ for manured plots, and $4.9 \mathrm{~mm}$ for unmanured plots) (Figure 18). As observed with previous soil physical 
properties, there is evidence that grass component improves wet aggregation despite no manure application.
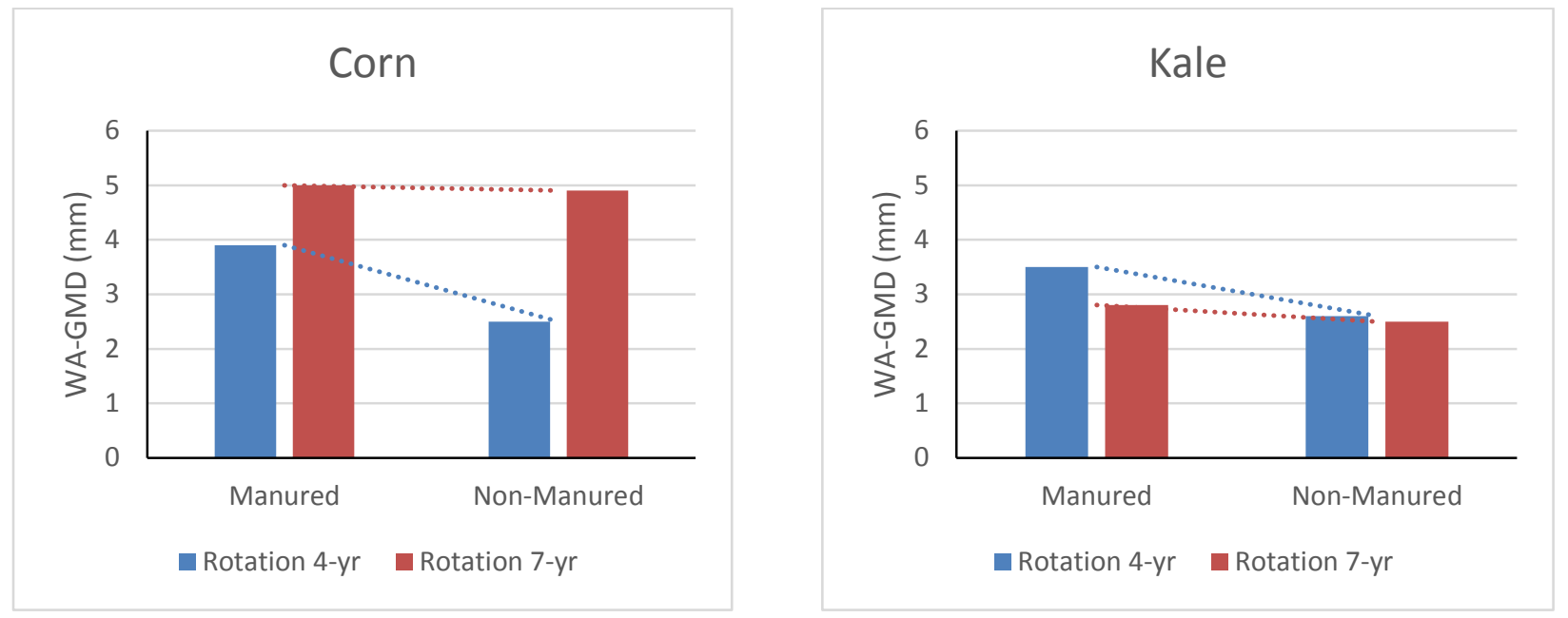

Figure 18. Interactions for wet aggregate geometric mean diameter (WA-GMD, 0-5cm) between manure and rotation between rotations (4-yr and 7-yr).

An interaction was observed between manure and rotation for soil organic matter (SOM). As with other soil properties (e.g. BD and DA-GMD), the presence of the grass component in the 7-yr rotation may explain the "protection" of organic matter; when the unmanured plots are compared for the $4-\mathrm{yr}(2.6 \pm 0.8 \%)$ and $7-\mathrm{yr}(3.5 \pm 1.3 \%), \mathrm{SOM}$ in the $7-\mathrm{yr}$ rotation is $34 \%$ higher than in the 4-yr rotation.

An interaction was observed between manure and rotation on soil $\mathrm{pH}$ in corn and kale plots at all depths (Tables 19 and 20). The interaction is expressed by an increased difference in $\mathrm{pH}$ between the manured and unmanured plots in 7-yr rotation as compared to the 4-yr rotation. It was previously mentioned that the grass component in 7-yr rotation may protect/preserve the organic matter and its related benefits (e.g. higher $\mathrm{pH}$, higher SOM content). 

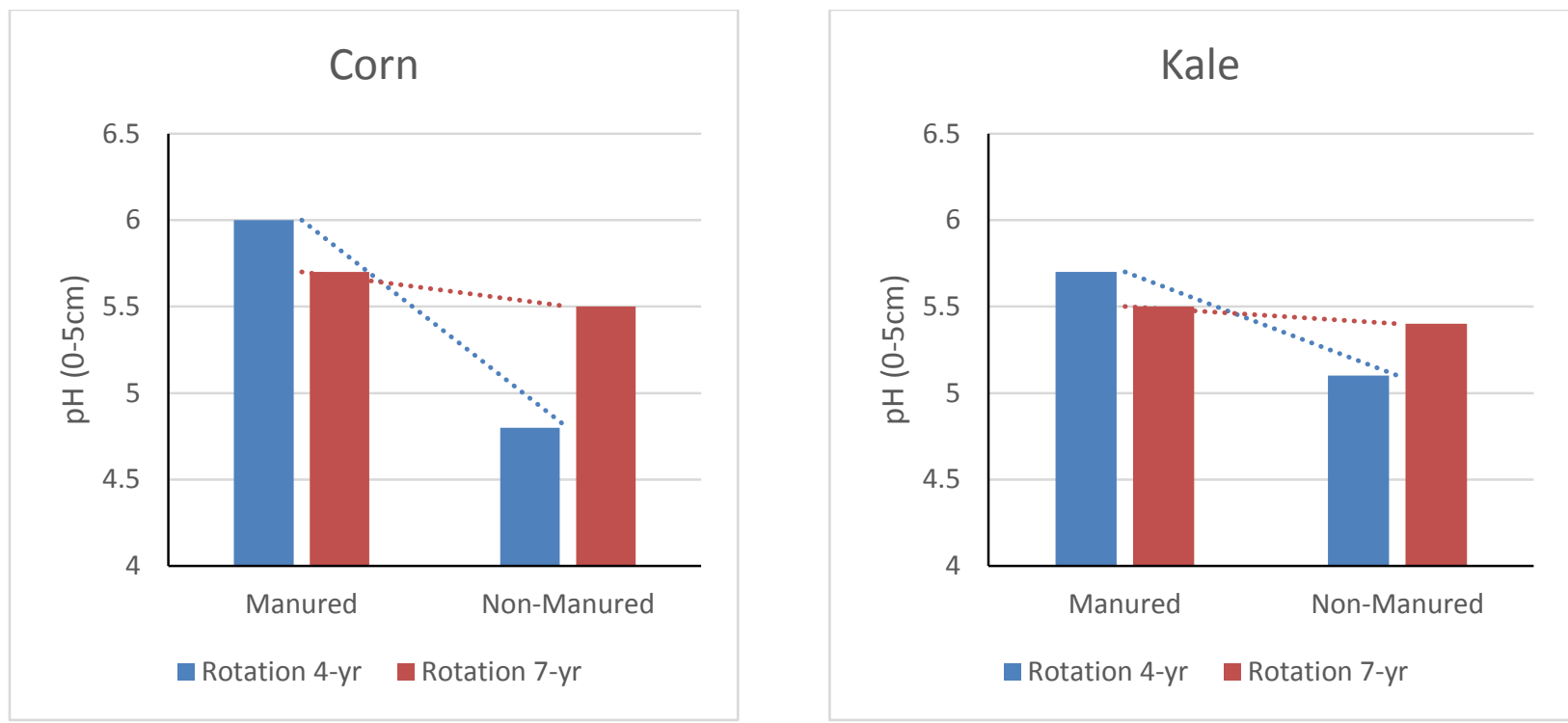

Figure 19. Interactions for $\mathrm{pH}(0-5 \mathrm{~cm})$ between manure and rotation between rotations $(4-\mathrm{yr}$ and 7-yr).
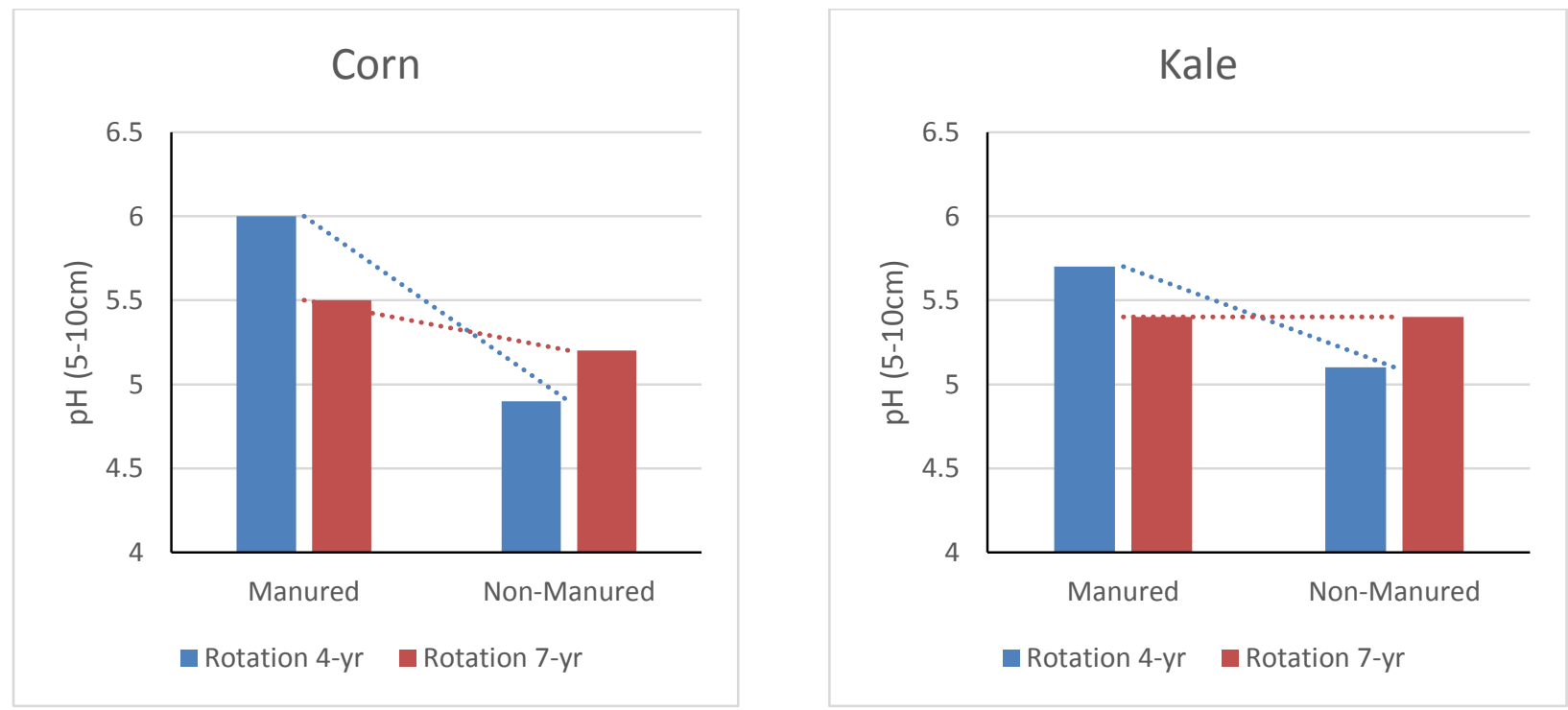

Figure 20. Interactions for $\mathrm{pH}(5-10 \mathrm{~cm})$ between manure and rotation between rotations (4-yr and 7-yr).

An interaction between manure application and rotation was observed for stratified SOM in corn plots at all depths, and in kale plots at the $5-10 \mathrm{~cm}$ depth. Behavior was similar to that discussed previously.

An interaction was observed between manure and rotation regardless of crop for STP (0$5 \mathrm{~cm}$ ) (Figure 21). Behavior was the same for the $5-10 \mathrm{~cm}$ depth. This interaction revealed that although the STP was higher in manured plots in the 4-yr rotation, STP was higher in the 
unmanured plots for the 7-yr rotation. STK for corn $(0-10 \mathrm{~cm})$ and for kale $(5-10 \mathrm{~cm})$ exhibited the same statistically significant interaction as the one previously described. The grass component included in 7-yr rotation appears to help store nutrients when no manure is applied.
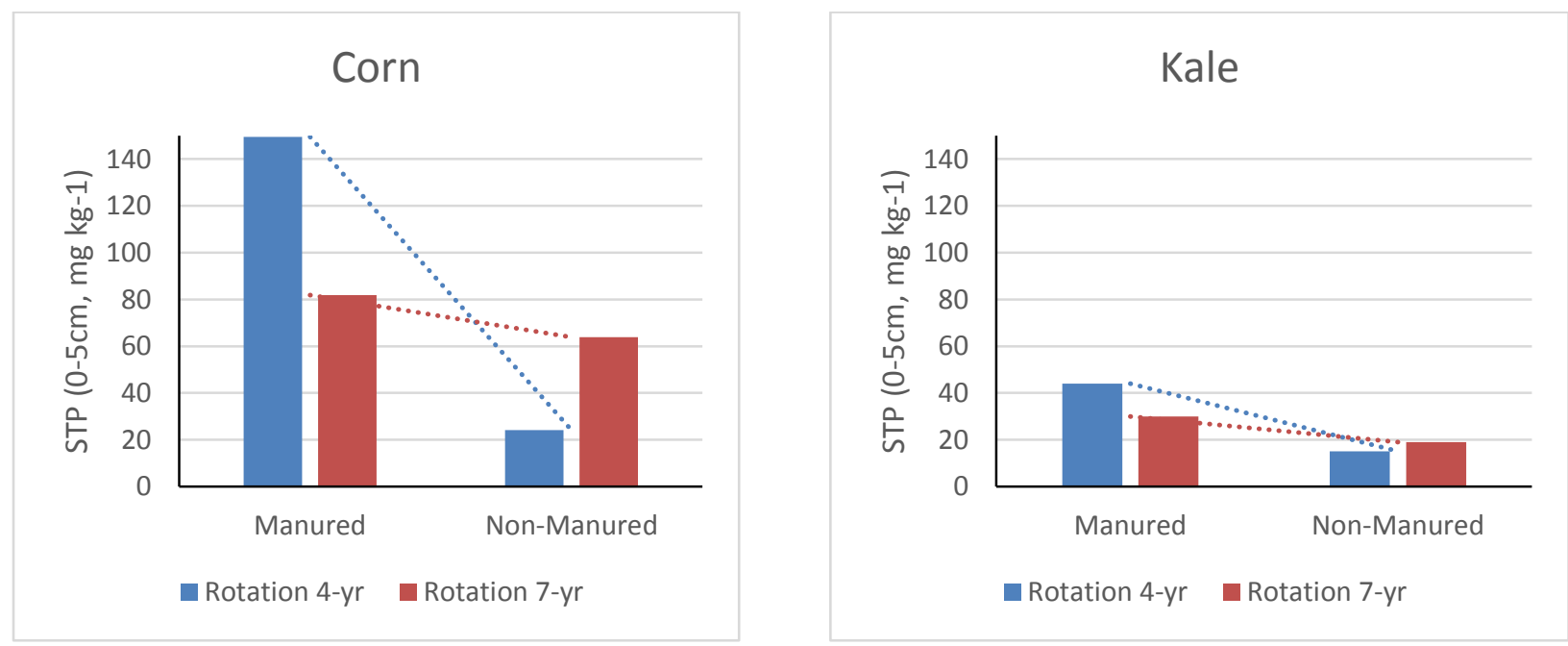

Figure 21. Interactions for soil test phosphorus (STP, $0-5 \mathrm{~cm})$ between manure and rotation between rotations (4-yr and 7-yr).

An interaction was observed between manure and rotation for STCa in corn plots, but not in kale plots. An interaction was observed for STMg, but only in kale plots. This interaction revealed that although the STMg was higher in manured plots in the 4-yr rotation, STMg was higher in the unmanured plots for the 7-yr rotation. The grass component in 7-yr rotation may store nutrients when no manure is applied.

Manure by rotation interaction was observed for zinc $(0-10 \mathrm{~cm})$ and $\operatorname{TotN}(5-10 \mathrm{~cm})$ regardless of the crop order in the cropping sequence; manured and unmanured corn and kale plots in the 7-yr rotation had similar STZn $(0$ to $10 \mathrm{~cm})$ and TotN $(5-10 \mathrm{~cm})$ behavior, but significant differences were observed when the corn and kale plots were in the 4-yr rotation. No interaction was observed for TotN $(0-5 \mathrm{~cm})$ for kale.

\section{Within Rotation Effect of Manure and Crop on Physical and Chemical Quality}

In 2014, soil property behavior was similar to that measured in 2013, although the magnitude of these properties differed slightly. Therefore discussion of 2014 results will be directed toward any differences found between the 2013 and 2014 datasets. 


\section{Manure effect within rotation type (4-yr and 7-yr)}

2014 surface bulk density values were statistically significantly affected by composted manure addition independent of rotation type. Plots receiving composted manure exhibited significantly lower bulk density (Table 15). Dry aggregate stability (DA-GMD) values were not affected by addition of manure in either rotation. Wet aggregate stability (WA-GMD) values were not significantly affected by addition of manure in 4-yr plots, but were significantly larger in manured plots in the 7-yr rotation (Table 15). Plots in the 4-yr rotation were tilled every year disrupting aggregation processes that create water stable aggregates; however three years of grass in the 7-yr rotation increases the possibility of producing large water stable aggregates (Six et al., 2001).

In the 4 and 7-yr rotation cycles, $\mathrm{pH}$ and $\mathrm{SOM}$ were both significantly affected by composted manure addition at all depths (Table 16). In all cases, soil $\mathrm{pH}$ and SOM were higher in manured plots than in unmanured plots. This effect is discussed in the 2013 nutrient analysis.

As was found for the year 2013, in 2014 stratified bioavailable nutrients responded directly to the manure application in this study. In this paragraph STP, STK, STCa, STMg, STZn and TotN are discussed together. Nutrients were higher in manured plots than in unmanured plots.

\section{Crop effect within rotation type (4-yr and 7-yr).}

As was found for 2013, a significant effect of crop was observed on bulk density, DAGMD, and SOM regardless of rotation cycle (Table 15). Corn plots showed higher DA-GMD than kale plots (Table 15). Wet GMD was significantly higher in the 4-year rotation kale than in the corn plots. No significant effect of crop was observed in the 7-year plots. No literature supporting either of the results could be found. Corn plots in the 7-yr rotation exhibited statistically significantly higher SOM than kale plots. However kale plots had significantly higher SOM values than corn plots in the 4-yr rotation (Table 15). This may be explained 
together with soil chemical properties by the fact that composted manure is added directly to corn plots and not to kale plots.

A significant effect of crop was found only at the $5-10 \mathrm{~cm}$ depth for $\mathrm{pH}$. In this case, soil $\mathrm{pH}$ values were higher in kale plots than in corn plots. No significant effect of crop was found on $\mathrm{pH}$ in the 7-yr rotation. Stratified soil organic matter (SOM) was significantly higher in kale plots than in corn plots in the 4-yr rotation, but in the 7-yr rotation, the opposite was true: SOM values in corn plots were significantly higher than in kale plots (Table 16). It is possible that the corn plots receive an increase in SOM from the grass component, which benefits corn plots in the 7-yr rotation, as this increase is absent in the 4-yr rotation.

Soil test phosphorus (STP) was significantly higher in 4-yr kale plots than in 4-yr corn plots, but in the 7-yr rotation STP was significantly higher in corn plots (Table 17). As explained previously, the fact that 7-yr corn plots have just emerged from the three years of temporary grass component, and that manure is added directly to corn plots and not to kale plots, may cause this response.

Similarly to 2013 results, a significant effect of first or last crop in the rotation was also found at all depths regardless of rotation. Soil test potassium (STK) was higher in corn plots than in kale plots in both rotations (Table 17). As mentioned previously, timing of manure addition may explain this result.

An effect of crop was observed on STCa, but not on STMg. In 4-yr plots, STCa values were significantly higher in kale plots than in corn plots, but in the 7-yr rotation STCa values were higher in corn plots than in kale plots.

A significant effect of crop was also observed on both STZn and TotN. In the 4-yr rotation, these nutrient values were higher in kale plots than in corn plots. In the 7-yr rotation STZn and TotN were significantly higher in corn plots than in kale (Table 19).

\section{Interactions between manure and crop within rotation type (4-yr and 7-yr).}

There was a significant interaction between manure and crop on BD in the 4-yr rotation: manure corn and kale had similar BDs, however when the plots were manured, corn plots experienced an important decrease in BD as compared to kale plots. This may be explained by the fact that corn received composted manure directly at planting time, while kale did not. As 
was found and discussed for 2013 data, 7-yr rotation did not show an interaction between manure application and crop, indicating that the grass component may have improved the soil bulk density in a way that it was able to override the manure effect during the crop duration of the rotation.

In 2014 and 2013, an interaction between manure and crop in the 4-yr plots was observed on SOM values. This interaction may have been caused by a mismanagement of the 2014 sampled kale plots: some of the plots were incorrectly manured.

An interaction was observed for $\mathrm{pH}$ between manure and crop at all depths in 7-yr plots, and for SOM in 4-yr plots at all depths. In the 4-yr rotation this interaction shows that although $\mathrm{pH}$ is always lower in unmanured plots, corn plots have a bigger difference in $\mathrm{pH}$ than the kale plots. As in the year 2013, this may be due to the manure application schedule in which manure is applied to the first (corn) and third (wheat) crop of the rotation, while kale does not receive manure directly.

Interactions were observed between manure and crop for STP, STK, STZn and TotN, regardless of rotation. At all depths unmanured corn and kale plots had similar nutrient values, but significant differences were observed when the corn and kale plots were manured. Timing of manure application may explain this observation. Because the behavior of these nutrients is so similar to 2013, more thorough discussion of their behavior may be found in the 2013 section.

\section{Between-Rotation Effect of Manure and Rotation on Physical and Chemical Quality, and Biomass}

In 2014, soil property behavior was similar to that measured in 2013, although the magnitude of these properties differed slightly.

In 2014, corn rows were planted at a greater distance $(0.9-1.1 \mathrm{~m})$ than in $2013(0.75-$ $0.8 \mathrm{~m})$. Additionally, distance between plants in a row were measured to be highly variable (ranging from 0.12 to $0.30 \mathrm{~cm}$ ) and mostly toward the low end of this spectrum. This makes statistical analysis of this data inefficient for performing comparisons within 2014, and together with 2013 biomass data. Due to the previous experimental issues, the 2014 corn biomass data were presented on a per-plant basis, and no ANOVA was run on these data. In Table 25 the 2014 
mean, standard deviation, and coefficient of variation per treatment for stalk + leaves, ear, kernel, and total cumulative biomass per corn plant are presented.

2014 cowpea biomass data were also incomplete, due to mismanagement of the manure application on "kale" plots before the pre-established sampling date. In addition, cowpea biomass samples were not able to be gathered for the entire 7-yr treatment, as they were grazed by sheep earlier than expected, and the plant material was lost. Data available therefore may only be used to compare the manure treatment to the unmanured treatment within the 4-yr rotation.

\section{Manure effect between rotations, within first and last crop in the sequence.}

Similarly to the year 2013, in 2014 manured plots significantly decreased BD regardless of crop (Table 20). Dry aggregate stability values (DA-GMD) for 2014 were significantly larger in corn plots not receiving composted manure than those receiving composted manure, as shown below in Table 20. However, dry aggregate stability was significantly larger in manured kale plots than unmanured plots. There was significant effect of manure on WA-GMD regardless of crop. Wet aggregate stability GMD (WA-GMD) values were significantly larger in both corn and kale plots receiving composted manure than those not receiving composted manure (Table 20). This observation supports findings from 2013. Statistically significant effects of manure application were observed on SOM for the first (corn) and the last (kale) crop in the rotations. SOM values were higher in manured corn and kale plots (Table 20).

In 2014, the main effect of manure on soil $\mathrm{pH}$ and SOM was similar to the year 2013. pH and SOM were higher in manured plots than in unmanured plots (Table 21). As stated in previous discussion, the nutrients $\mathrm{P}, \mathrm{K}, \mathrm{Ca}, \mathrm{Mg}, \mathrm{K}, \mathrm{Zn}$, and $\mathrm{N}$ were found to be highly related to manure applied. Higher manure application related to higher nutrient content.

Corn biomass results suggested that, regardless of rotation cycle, manured corn plot biomass was consistently higher per plant than unmanured plots.

Manure application did not appear to have an effect on cowpea biomass, which is different from 2013 results. This discrepancy may be the consequence of kale plot manuring mismanagement. However, similar to 2013, weeds are the main component of the total biomass. 
Rotation type effect between rotations, within first and last crop in the sequence.

The effect of rotation was observed on BD regardless of crop component: 4-yr rotation always exhibited significantly higher BD than the 7-yr rotation. In corn planted plots, DA-GMD was significantly higher when in the 4-year rotation cycle, compared to the 7-year cycle corn plots. Kale plots did not show the same behavior, as no significant effect of rotation cycle was observed (Table 20). There was significant effect of rotation on WA-GMD regardless of crop. Although not significant, when corn was grown in the 4-yr rotation, WA-GMD was smaller than in corn plots in the 7-yr rotation. The opposite was observed for kale, although significant differences were observed. WA-GMD was smaller in the 7-yr rotation than in the 4-yr rotation.

A statistically significant effect of rotations was observed on SOM regardless of crop. Corn plots in the 7-yr cycle had higher SOM (possibly due to the grass component, in spite of less frequent manure addition), while kale plots in the 4-yr cycle had significantly higher SOM than kale plots in the 7-yr cycle (possibly due to more frequent manure application, and manure mismanagement in part of the sampled plots).

Only in the kale plots was soil $\mathrm{pH}$ at all depths significantly affected by rotation. In these cases, $\mathrm{pH}$ was higher in the 4-yr than in the 7-yr rotation. Soil Organic Matter values were significantly higher in 7-yr corn plots than in 4-yr corn plots, but in kale plots the trend reversed; SOM values in 4-yr kale plots were higher than those in 7-yr kale plots. It is possible that the manure added to corn plots masked the effect of rotation on $\mathrm{pH}$ and $\mathrm{SOM}$, while in kale plots the difference is more pronounced because no annual manure is added. It is also possible that the effect of rotation has diminished by the end of the cropping cycle, so that nutrient levels are more affected by manure application (which occurs more frequently in the 4-yr cycle than in the 7-yr cycle) than by rotation.

A significant effect of rotation was found on STP and STK, regardless of crop. Soil test phosphorus (STP) and STK were significantly higher in 7-yr corn plots than in 4-yr corn plots, but in kale STP and STK were significantly higher in the 4-yr rotation plots (Table 22). This may be due to the explanation in the previous paragraph. A significant effect of rotation on STCa was observed regardless of crop; in corn plots, values in the 7-yr rotation were significantly higher 
than those in the 4-yr rotation, while in kale plots values in the 4-yr plots were higher than those in the 7-yr plots. A significant effect of rotation was found on STMg only in kale plots at the 0$5 \mathrm{~cm}$ depth. In this case, STMg was significantly higher in 7-yr kale plots than in 4-yr kale plots (Table 23). This may be due to a residual effect in kale of the 7-yr rotation. There was a significant effect of rotation on STZn $(0-10 \mathrm{~cm})$ and TotN $(5-10 \mathrm{~cm})$ in corn and kale. In corn plots, STZn was significantly higher in 7-yr plots than in 4-yr plots, but only at the surface depth $(0-5 \mathrm{~cm})$. In kale, STZn values were significantly higher in the 4-yr rotation than in the 7-yr rotation (Table 24). Total nitrogen in corn plots was significantly higher in the 7-yr rotation, while in kale plots it was significantly higher in the 4-yr rotation.

Corn biomass results suggest that 7-yr rotation per-plant-biomass was always (when holding manure addition constant) higher than that of the 4-yr rotation.

The effect of rotation cycle on 2014 cowpea biomass could not be established with the current biomass observations. It was not possible to relate the statistically significant effect of manure and/or rotation cycle on soil quality indicator variables (physical and chemical) to the resulting 2014 biomass production.

The 2014 incomplete biomass information gathered in the field was not adequate to fulfill the studies objective to measure differences in biomass between first and last crop components of two rotation cycles subjected at two levels of composted manure.

\section{Interactions between manure and rotation, within first and last crop in the sequence.}

An interaction was observed between manure and rotation in corn plots on bulk density values; manure application was associated with less of a decrease in BD in 4-yr rotation than in 7 -yr rotation. Grass roots may have provided higher porosity to the 7-yr plots; this statement is supported by the fact that kale plots, which were not following a grass component, did not show an interaction between manure and rotation.

An interaction was observed between manure and rotation in kale plots, but not for the corn plots. In previous paragraphs, mismanagement on the 2014 sampled kale plots was cited as a possible explanation for this. 
An interaction was observed between manure and rotation for $\mathrm{pH}$ and $\mathrm{SOM}$ at all depths in corn plots and for SOM in kale, however no interaction was observed for $\mathrm{pH}$ in kale. In previous paragraphs the mismanagement of some of the kale plots was discussed, and may explain this result. An interaction was observed between manure and rotation at all depths for STP, STK, STCa, STZn, and TotN regardless of crop.

2014 corn biomass values are presented as per-plant measurements, due to previously discussed problems with the plant stand. Means may be compared in a relative sense; biomass values are highest where the manure and the 7 -yr rotation treatment are combined. The same trend is visible for cowpea biomass values; the highest biomass values are in manured plots, compared to unmanured plots, and values in the manured 7-yr plots are highest overall. It is interesting to note that the lowest overall values are in unmanured 7-yr plots.

\section{EXPERIMENT II:}

\section{Within-Rotation Effect of Manure and Crop on Transition into and out of Temporary Grass Component}

The transition from crops (kale) into grass was expected to impact soil quality for reasons such as management changes from annual tillage, planting, and harvesting of crops to no tillage or mechanical activity. This pause in tillage has been reported to affect bulk density, aggregate stability, and SOM (Guo et al., 2010; Feng et al., 2011). Orchardgrass and red clover residues are left on the surface, protecting the soil surface and contributing to surface SOM, and roots of the grass impact soil structure and aggregate stability (Carter et al., 1994; Calegari et al., 2010). Because red clover is a legume, it contributes $\mathrm{N}$ to the soil. While manure is not added to the grass component, residual effects of manure application to corn and wheat plots earlier in the cropping cycle of manured plots may be measured.

The 2014 stratified elements were chosen for study because they could be mobilized and removed by the crops, and may be sensitive to transition processes. 


\section{Manure effect within rotation on transition into and out of temporary grass component}

In 2013, as measured in the transition into the grass component, manure application had a significant effect on all soil physical properties measured. Bulk density was significantly lower in manured plots, compared to unmanured plots (Table 27). Dry Aggregate stability (GMD) was higher in unmanured plots, compared to manured plots. Wet Aggregate stability (GMD) and SOM were both higher in manured plots than in unmanured plots.

In 2013, as measured in the transition into the grass component, manure application had a significant effect on $\mathrm{pH}$ and SOM at all depths (Table 28). In all cases, values were higher in manured plots than in unmanured plots. Soil test phosphorus and STK behaved similarly to $\mathrm{pH}$ and SOM. An effect of manure was observed at all depths; nutrients were higher in manured plots (Table 29). Soil test calcium and TotN also behaved similarly to the previously discussed nutrients. The effect of manure was significant on both nutrients at all depths, with significantly higher values in manured plots than those in unmanured plots (Table 30).

In 2013, as measured in the transition out of the grass component, regardless of crop (grass or corn) manured plots had significantly lower BD than plots in the unmanured treatment. No significant effect of manure application was observed on DA-GMD, WA-GMD, or SOM.

As was found for the transition from crops to grass, $\mathrm{pH}$ and SOM in the transition from grass to crops (third year of orchardgrass mix (O7) and first crop corn) were significantly affected by manure application (Table 28). At all depths, manured plots exhibited higher $\mathrm{pH}$ and SOM. This was also the case for STP, STK (Table 29), STCa and TotN (Table 30). Manure application and possible grass biomass decomposition provided bioavailable nutrients benefits when transitioning from grass into corn on indicators such as SOM.

\section{Crop effect within rotation on transition into and out of temporary grass component}

Crop treatment, represented by kale (last crop before grass) and first year of orchardgrass mix (O5), had a significant effect on physical properties. BD in O5 was significantly higher than that in the kale plots. This is to be expected, since kale plots are tilled in the spring, left to cowpeas in summer, and less intensively tilled in fall to plant O5. By the following spring, when 
O5 measurements are taken, the soil appears to have settled and increased in density (reconsolidated). It is important to note that in most cases an increase in BD is considered a decrease in soil quality, but the increase observed in this study was not limiting to plant growth.

Crop treatment also had a significant effect on aggregate stability. Dry Aggregate stability (GMD) was significantly higher in 05 plots, compared to kale plots (Table 27). Wet Aggregate stability (GMD), however, was significantly higher in kale plots than it was in O5 plots. Soil organic matter was not significantly affected by crop.

An effect of crop was only observed in stratified SOM at the $0-5 \mathrm{~cm}$ depth; O5 plots had higher SOM than kale plots. This might be attributable to the effect of the grass component increasing SOM by virtue of added root mass and surface residues. This observation supported Guo et al. (2010) findings, in which the authors reported that Total N and SOM increased significantly when cropland was converted to grassland. An effect of crop was observed in both STP and STK but only at the $0-5 \mathrm{~cm}$ depth, in which 05 values were greater than those in kale. The effect of crop was also significant for both STCa and TotN at all depths. Nutrient values in the O5 plots were higher than those in the kale plots.

The subsequent transition from grass to crops (third year of orchardgrass mix (O7) and first crop corn) was also expected to impact soil quality for the same reasons mentioned previously. The transition from grass to cropping systems has been shown to lower BD (due to tillage) (Guo et al., 2010; Feng et al., 2011), but also decrease aggregate stability due to mechanical breakdown. SOM is also known to decrease upon converting pasture to cropland due to increased microbial activity and crop demand for soil nutrients (Aslam et al., 1999).

A significant effect of crop was observed on BD; corn plots had significantly lower BD than $\mathrm{O} 7$ plots, presumably due to tillage (Table 27). Crop also had a significant effect on aggregate stability. Corn plots had significantly higher DA-GMD than O7 plots, while O7 plots had significantly higher WA-GMD than corn plots. For three years the grass component may have allowed organic matter to accumulate, which is conducive to aggregation processes and water aggregate stability, while tillage may have produced bigger massive dry aggregates in the corm plots. No significant effect of crop was observed on SOM.

An effect of crop was observed in both $\mathrm{pH}$ and SOM, but only at the $5-10 \mathrm{~cm}$ depth (Table 28). In both cases, nutrients were higher in $\mathrm{O} 7$ plots than in corn plots. This may be due to the stimulating effect tillage has on microbial decomposition of SOM, although it is interesting 
that manure added to corn plots does not bring values in corn plots to equal or surpass those in the O7 plots. An effect of crop was observed on STP and STK values for 2013 (Table 29). For both nutrients, values in corn plots were significantly higher than those in O7 plots, but only at the surface depth. A significant effect of crop was observed for STCa, but not for TotN (Table 30). Soil test calcium in $\mathrm{O} 7$ plots is significantly larger than in corn plots at all depths.

Data did not indicate a significant change in biomass production due to "year in grass" during the temporary grass component. However, a gradual increase was observed over the years in grass. In forage/grass production, the first years of establishment are characterized by a lover biomass yield; this was not observed in the data collected in this study. It was possible that at the beginning of the transition, grass growing in the manured plots took advantage of existing residual fertility and improved soil properties, increasing the establishment phase for biomass. Additionally, grass plots follow kale and cowpeas, which may, in the unmanured plots, increase nitrogen during the grass establishment phase.

\section{Interaction between manure and crop on transition into and out of temporary grass component}

An interaction between manure and crop was found for BD (Figure 22), DA-GMD (Figure 23), and SOM (Figure 24). For these properties, decrease in soil quality when manure was not applied was more evident in corn plots (high magnitude interaction).
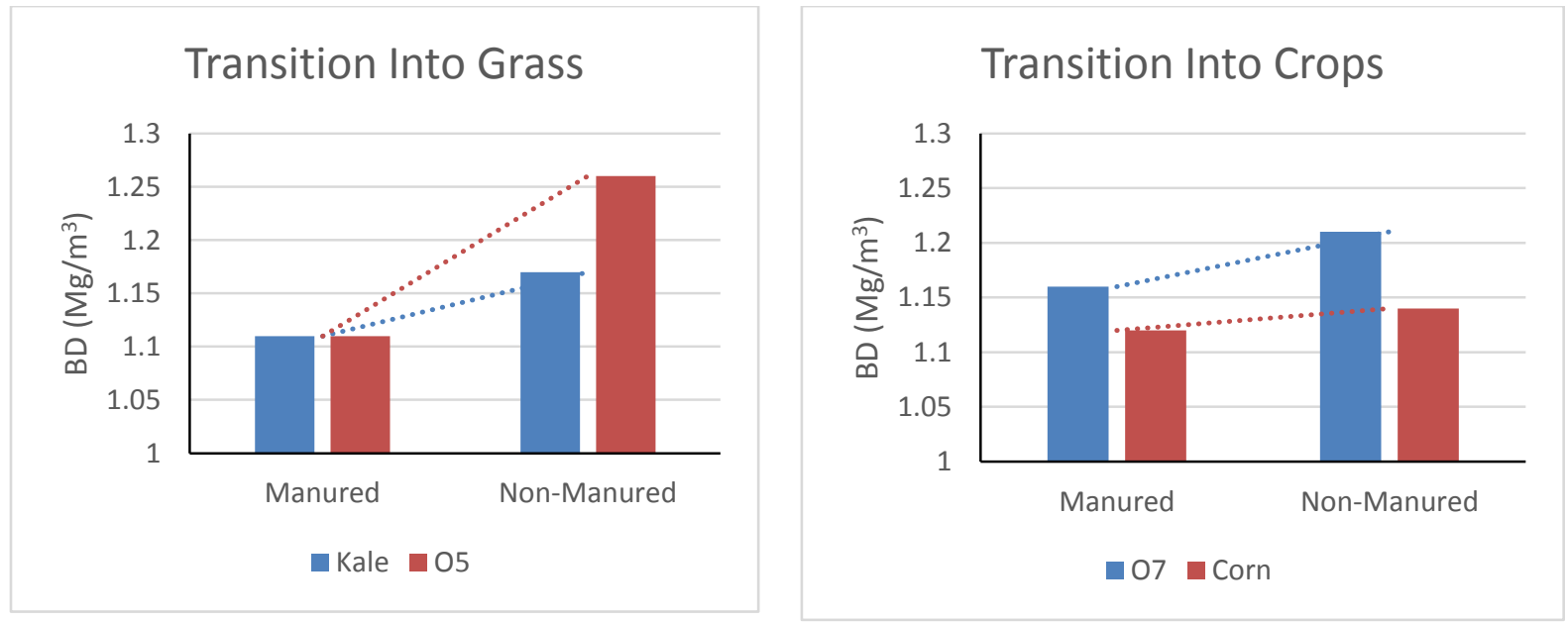

Figure 22. Interactions for bulk density $(\mathrm{BD}, 0-5 \mathrm{~cm})$ between manure and crop during transition into and out of temporary grass component. 

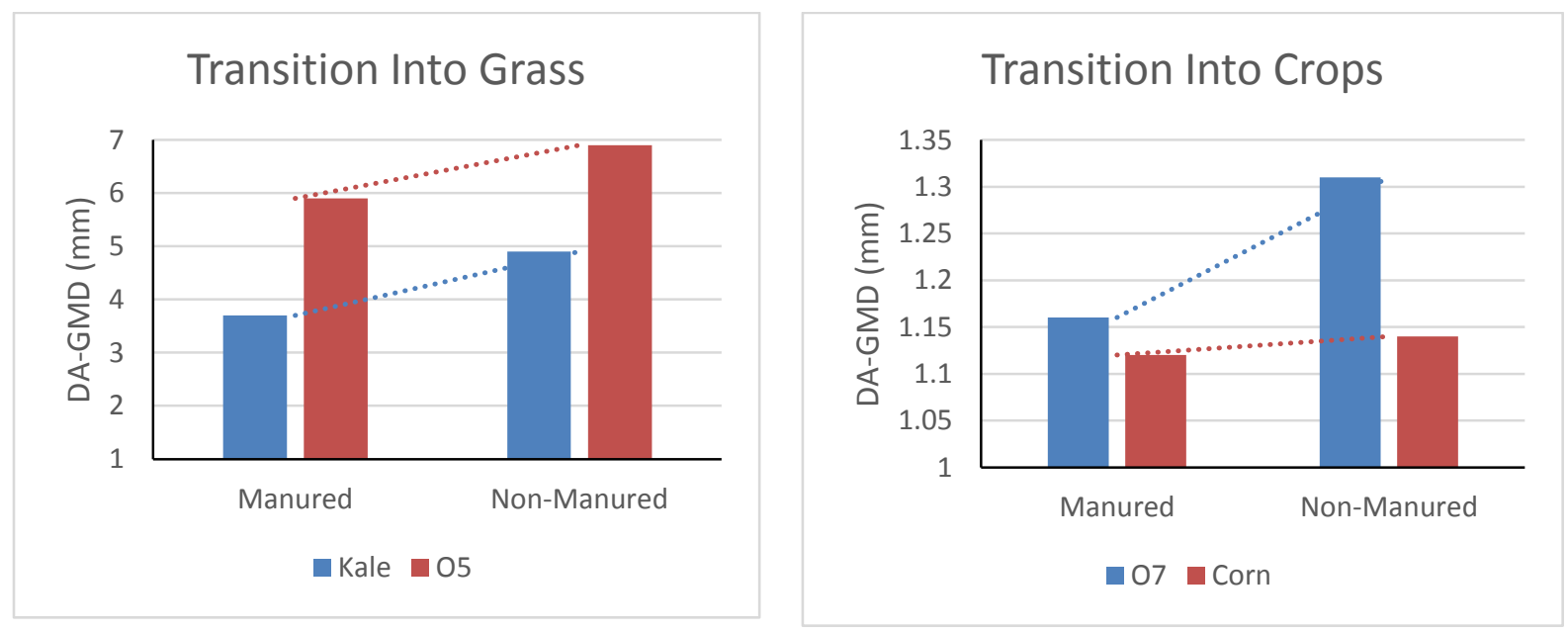

Figure 23. Interactions for dry aggregate geometric mean diameter (DA-GMD, 0-5cm) between manure and crop during transition into and out of temporary grass component.
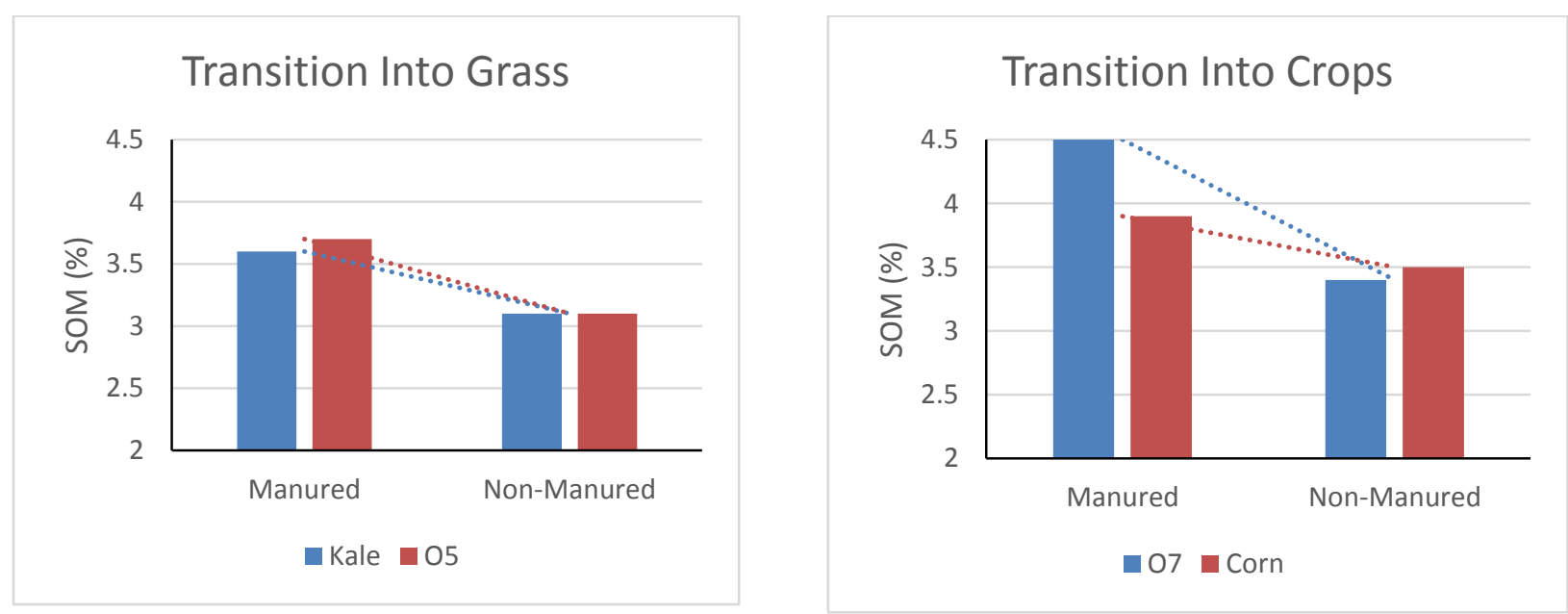

Figure 24. Interactions for soil organic matter $(\mathrm{SOM}, 0-5 \mathrm{~cm})$ between manure and crop during transition into and out of temporary grass component.

An interaction of manure and crop was observed for $\mathrm{pH}$ (Table 25). Although Guo et al. (2010) found surface $\mathrm{pH}$ to decrease significantly when cropland was converted to grassland, our data did not show a significant difference when manure was applied to the plots. 

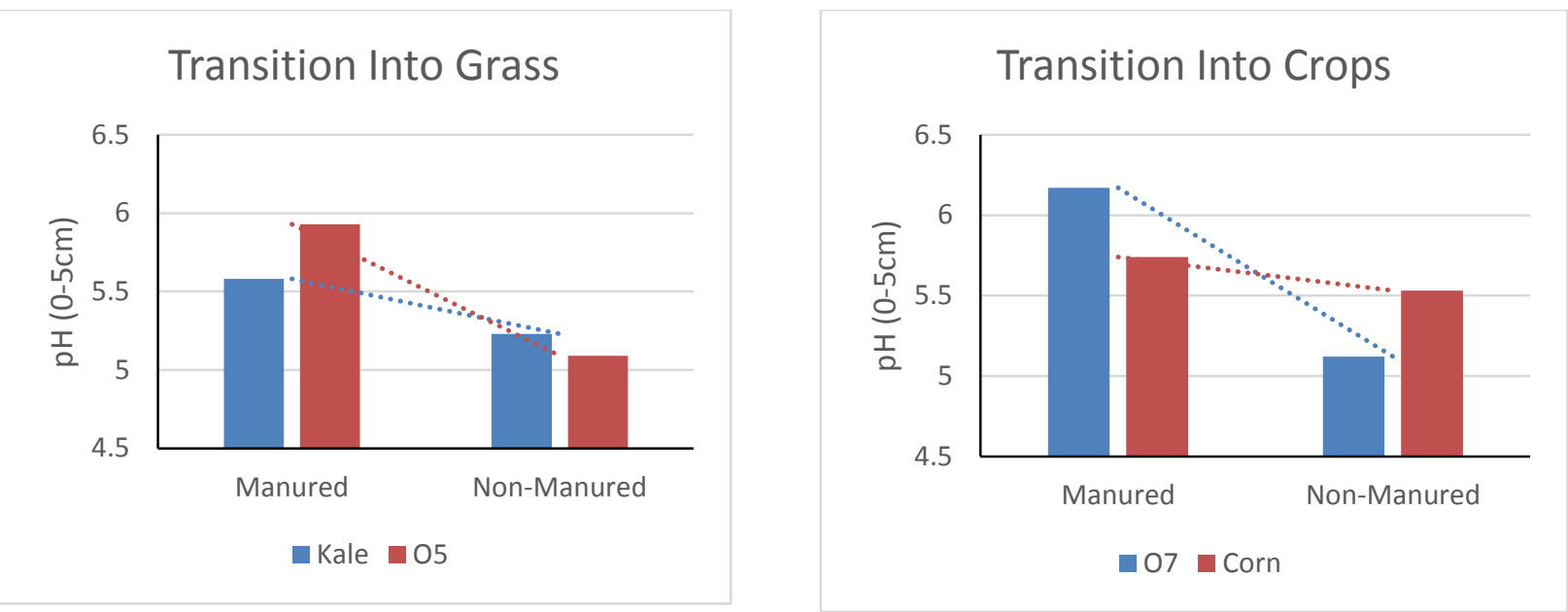

Figure 25. Interactions for $\mathrm{pH}(0-5 \mathrm{~cm})$ between manure and crop during transition into and out of temporary grass component.

The increase in overall STP observed in this experiment also does not support findings reported by Guo et al. (2010). Those authors found that STP decreased significantly during transition. However, when analyzing the significant interaction between manure and crop was found only on STP, it was possible to observe that when manure was "not applied" to the plots, STP reduction was higher in the grass plots than in the kale plots, which may indeed support Guo et al. (2010) findings. An interaction was found between manure and crop on TotN at all depths. It seems that despite the more recent application of manure onto kale plots, the effect of the grass in O5 plots has a potentially protective effect of SOM and nutrients.
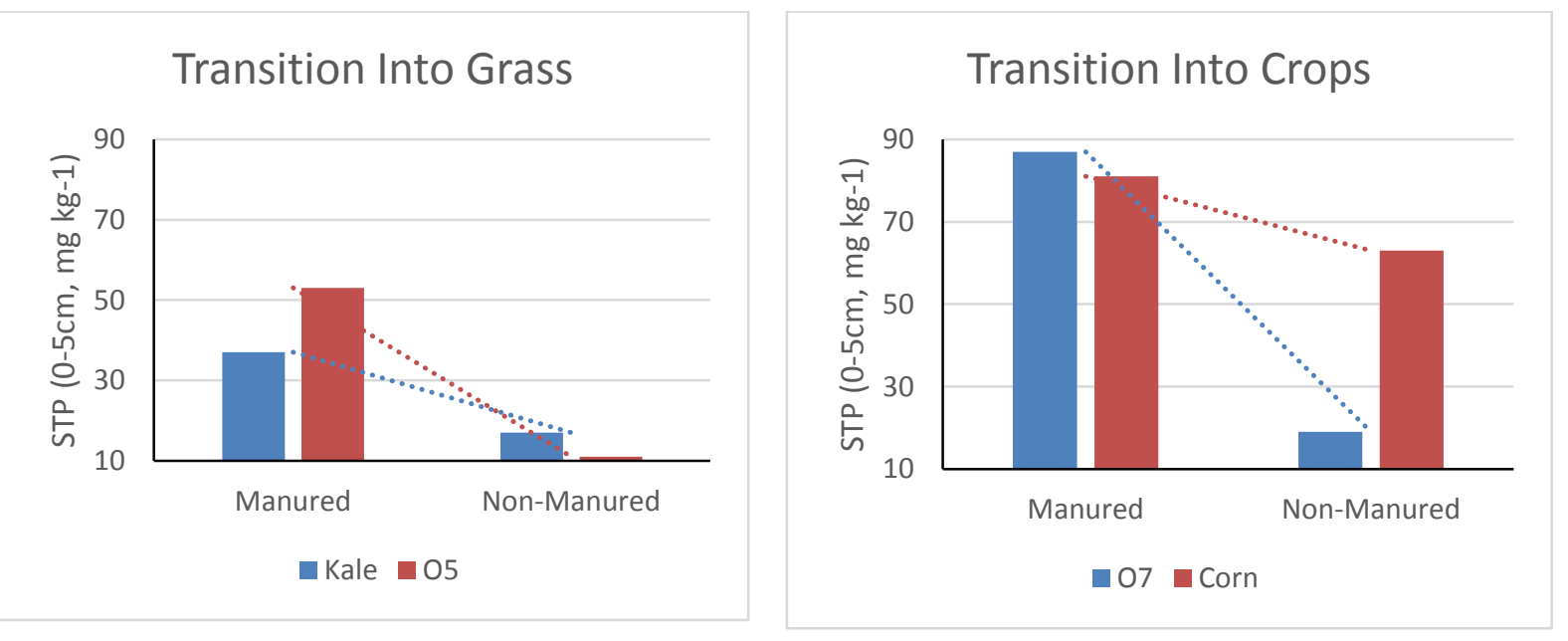

Figure 26. Interactions for soil test phosphorus (STP, 0-5cm) between manure and crop during transition into and out of temporary grass component. 
Interactions between manure and crop were found for $\mathrm{pH}$ at both depths, and for SOM at the surface $(0-5 \mathrm{~cm})$ depth. An interaction between manure and crop was found for STP at all depths and for STK at the $5-10 \mathrm{~cm}$ depth. In this case, manure application to corn plots appears to increase STP and STK above levels in the grass component. An interaction between manure and crop was observed for STCa at all depths and for TotN at the $0-5 \mathrm{~cm}$ depth.

Manure application on crops may be considered a confounding effect. However comparing corn or grass plots in which no manure was applied, and observing the increase in bioavailable nutrients in these unmanured corn plots can only be explained by the nutrients available in the grass material the year before the transition. More research is recommended in this area.

\section{Within-Rotation Effect of Manure and Crop on Transition into and out of Temporary Grass Component}

Physical properties behaved very similarly to the way they did in 2013 . Therefore some of the discussion is only included in the 2013 result section. The 2014 stratified elements were chosen for study because they could be mobilized and removed by the crops, and may be sensitive to transition processes. Some 2014 bioavailable nutrient data were very similar to those measured in 2013, and as a consequence part of the data analysis has been presented in more detail in the previous 2013 discussion.

\section{Manure effect within rotation on transition into and out of temporary grass component}

In 2014, as measured in the transition into the grass component, manure application had a significant effect on $\mathrm{BD}$, which was significantly lower in manured plots, compared to unmanured plots (Table 31). Dry aggregate stability was not significantly affected by manure application. Wet aggregate stability and SOM were both higher in unmanured plots than in manured plots.

In 2014, as measured in the transition into the grass component, manure application had a significant effect on pH, SOM, STP, STK, STCa, and TotN at all depths (Table 32-34). In all 
cases, values were higher in manured plots than in unmanured plots. This is expected, as the selected bioavailable nutrients correlate with manure application.

In the 2014, the transition from grass to crops (third year of orchardgrass mix (O7) and first crop corn), manure application and crop had a significant effect on BD, WA-GMD and SOM. Plots in the manure treatment had significantly lower BD, higher WA-GMD and higher SOM than plots in the unmanured treatment, regardless of crop. The DA-GMD was not affected by manure application.

For the transition from the third year of grass (O7 to corn), as for 2013, in 2014 manure application significantly affected pH, SOM, STP, STK, STCa, and TotN (Table 32-34). At all depths, manured plots exhibited higher nutrients content.

In both years there is a statistically significant increase in grass biomass in previouslymanured plots.

\section{Crop effect within rotation on transition into and out of temporary grass component}

As in 2013, in 2014 crop treatment (kale or O5) also had a significant effect on BD in the transition into the grass component. Bulk density in the first year of grass (O5) was significantly higher than that in the kale plots (before the transition). In the previous section we explained the possible reasons for this observation. Different from 2013, in 2014 crop treatment did not have a significant effect on DA-GMD, WA-GMD, or SOM. A mismanagement event in the kale plots that may have altered these results was discussed previously.

An effect of crop (kale or O5) was only observed in SOM at the $0-5 \mathrm{~cm}$ depth, as was the case in 2013. O5 plots had higher SOM than kale plots (Table 32). This might be attributable to the effect of the addition of organic matter by the grass component.

Related to STP, at all depths O5 exhibited statistically significantly greater values than those in kale. This was not observed for STK.

As was observed in 2013, in 2014 the effect of crop (kale or O5) was also significant for TotN at all depths, but not for STCa. Nutrient values in the kale plots were higher than those in the $\mathrm{O5}$ plots (Table 35). 
Regarding crops, corn plots exhibited in average lower BD, WA-GMD and SOM than O7 plots. As was found in 2013, corn plots had significantly higher DA-GMD than O7 plots, while O7 plots had significantly higher WA-GMD than corn plots.

An effect of crop ( $\mathrm{O} 7$ = last year in grass, or corn) was observed only at the $5-10 \mathrm{~cm}$ depth SOM (Table 32). SOM values were higher in corn plots than in $\mathrm{O} 7$ plots. An effect of crop was observed on STK values for 2014 (Table 33). On average, STK values in corn plots were significantly higher than those in $\mathrm{O} 7$ plots at all depths. Direct application of manure to the corn plots may explain this observation. A significant effect of crop was observed for TotN at the 5$10 \mathrm{~cm}$ depth, but not for STCa (Table 34). In this case TotN in corn plots was significantly larger than in $\mathrm{O} 7$ plots.

Data did not indicate a significant change in biomass production due to "year in grass" during the temporary grass component. However, a gradual increase was observed over the years in grass. Discussion of this result is found in 2013 results for this experiment.

\section{Interaction between manure and crop on transition into and out of temporary grass component}

An interaction between manure and crop was observed for BD and WA-GMD for the transition out of the grass component. For the transition into the grass component, an interaction of manure and crop was observed for $\mathrm{pH}$ at all depths and for SOM at the surface depth. As was discussed previously, there is an effect of manure and SOM on buffering soil $\mathrm{pH}$. An interaction between manure and crop was found in both nutrients $\mathrm{P}$ and $\mathrm{K}$, at all depths. The decrease in STP supports previous observations reported by Guo et al. (2010), however related to STK we observe an increase in this nutrient under the unmanured grass component. An interaction was found between manure and crop on STCa at all depths, and on TotN at the surface depth. Soil test $\mathrm{Mg}$ and STZn behaved similarly to STCa, and were therefore omitted in this discussion.

Regarding the transition from grass to crops, interactions between manure and crop were not observed for $\mathrm{pH}$ or SOM.

An interaction between manure and crop was observed for TotN at all depths and for $\mathrm{STCa}$ at the $0-5 \mathrm{~cm}$ depth. The interaction suggests that corn plots are more sensitive to manure application than $\mathrm{O} 7$ plots. However, both interactions may be explained by the manure 
application timing: manure is applied directly to corn plots increasing nutrients levels. In the case of the $\mathrm{O} 7$ plots, no manure has been added for four previous years; only residual manure application may be responsible for nutrient content. Unmanured plots for corn or $\mathrm{O} 7$ exhibit similar fertility levels for TotN and STCa.

Data did not show an interaction between "years into the transition" and manure application.

\section{Conclusions}

The results of this research increase the understanding of soil quality changes in organic crop rotations. At a time when organic agriculture is becoming more common, few studies have measured soil physical property changes associated with the inclusion of a temporary grass component in organic crop rotations. Long-term crop rotation studies are required in organic agricultural systems, and require careful logistical and temporal commitment. They present a unique opportunity to study complex agricultural systems which may take many years to stabilize. The results of this research may indicate trends in the in the rotation system. Whether or not complex rotational cropping systems ever stabilize is a topic for future research.

It is important to note that it was outside the scope of this study to determine whether changes due to the 7-yr rotation are attributable to "the effect of the grass", "the pause in tillage", or "the brief sheep grazing events". The comparison of the 7-yr rotation to the 4-yr rotation did not allow for separation of these individual agents of change, and they are therefore considered together as the effect of the "temporary grass component".

Manured plots within rotation nearly always exhibited significantly higher soil physical quality than unmanured plots (e.g. for 2013, Bulk density (BD) 4-yr Manured (M): 1.09Mg/m³, 4-yr Unmanured (U): $1.22 \mathrm{Mg} / \mathrm{m}^{3}, 7-\mathrm{yr} \mathrm{M}: 1.15 \mathrm{Mg} / \mathrm{m}^{3}, 7-\mathrm{yr} \mathrm{U}: 1.24 \mathrm{Mg} / \mathrm{m}^{3}$; Dry Aggregate stability (GMD) 4-yr M: 3.6mm, 4-yr U: 4.6mm, 7-yr M: 5.3mm, 7-yr U: 6.4mm; Wet aggregate stability (GMD) 4-yr M: 3.7mm, 4-yr U: 2.6mm, 7-yr M: 4.7mm, 7-yr U: 4.6mm; Soil Organic Matter 4-yr M: 3.9\%, 4-yr U: 2.7\%, 7-yr M: 4.9\%, 7-yr U: 3.2\%).

The same trend was found for soil chemical quality; manured plots exhibited significantly higher plant available nutrients than unmanured plots (e.g. pH 4-yr M: 5.8, 4-yr U: 5.0, 7-yr M: 5.9, 7-yr U: 5.2; Phosphorus 4-yr M: 96.7mg/kg, 4-yr U: 19.7mg/kg, 7-yr M: 70.8mg/kg, 7-yr U: 
$26.2 \mathrm{mg} / \mathrm{kg}$; Potassium 4-yr M: 201mg/kg, 4-yr U: $111 \mathrm{mg} / \mathrm{kg}$, 7-yr M: $175 \mathrm{mg} / \mathrm{kg}, 7-y r$ U: 129mg/kg; Calcium 4-yr M: 2164mg/kg, 4-yr U: 1481mg/kg, 7-yr M: 2285mg/kg, 7-yr U: $1662 \mathrm{mg} / \mathrm{kg}$; Total nitrogen 4-yr M: 2.7g/kg, 4-yr U: 1.7 g/kg, 7-yr M: 2.9 g/kg, 7-yr U: 2.2 g/kg).

Corn Biomass (2014 values), provided in per-plant measurements, and 2013 Cowpea Biomass were also higher in manured plots than in unmanured plots [Corn Biomass 4-yr M: 326g, 4-yr U: 248g, 7-yr M: 436g, 7-yr U: 253g; Cowpea Biomass 4-yr M: 8.63 Mg/ha, 4-yr U: $5.69 \mathrm{Mg} / \mathrm{ha}, 7-\mathrm{yr} \mathrm{M}: 9.47 \mathrm{Mg} / \mathrm{ha}, 7-\mathrm{yr} \mathrm{U}: 4.25 \mathrm{Mg} / \mathrm{ha}$ ]. 2014 results were very similar to 2013 results, and "between-rotation" results were very similar to those found within rotation. These values are similar to those reported by other authors.

The observed effect of crop within rotation is likely explained by the timing of manure application. Since composted manure is added directly to corn plots, soil quality was often found to be higher in corn plots than in kale plots, which do not directly receive manure (e.g. DA-GMD 7-yr C: 5.1 mm, 7-yr K: 4.3 mm; WA-GMD 7-yr C: 4.9 mm, 7-yr K: 2.6 mm; SOM 4-yr C: 3.5\%, 4-yr K: 3.1\%; 7-yr C: 3.7\%, 7-yr K: 3.5\%; pH 7-yr C: 5.6, 7-yr K: 5.4; P 4-yr C: 86.9 mg/kg, 4-yr K: 29.6 mg/kg, 7-yr C: 72.9 mg/kg, 7-yr K: 24.5 mg/kg).

Between rotations, the 7-yr rotation improved bulk density (BD 4yr C: $1.7 \mathrm{Mg} / \mathrm{m}^{3}, 7 \mathrm{yr}$ C: $1.3 \mathrm{Mg} / \mathrm{m}^{3}$ ), DA-GMD (4yr C: $3.9 \mathrm{~mm}, 7 \mathrm{yr}$ C: $5.1 \mathrm{~mm}$ ), WA-GMD (4yr C: $3.2 \mathrm{~mm}, 7 \mathrm{yr} \mathrm{C}$ :

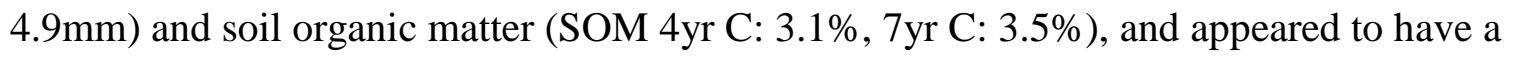
protective effect of SOM. Regardless of crop, Total $\mathrm{N}$ was also higher in the 7-yr rotation (C: 2.8 $\mathrm{g} / \mathrm{kg}, \mathrm{K}: 2.2 \mathrm{~g} / \mathrm{kg}$ ) than in the 4-yr rotation (C: $2.3 \mathrm{~g} / \mathrm{kg}, \mathrm{K}: 2.0 \mathrm{~g} / \mathrm{kg}$ ). The 7-yr rotation, however, did not always improve aggregate stability or plant available nutrients (WA-GMD 4yr K:

$3.0 \mathrm{~mm}, 7 \mathrm{yr} \mathrm{K}: 2.7 \mathrm{~mm} ; \mathrm{P}, 7-\mathrm{yr}$ C: $72.9 \mathrm{mg} / \mathrm{kg}$, 4-yr C: $86.9 \mathrm{mg} / \mathrm{kg}$, and by the end of the cropping cycle the same trend is visible, e.g. 7-yr K: $24.5 \mathrm{mg} / \mathrm{kg}$, and 4-yr K: $29.6 \mathrm{mg} / \mathrm{kg}$ ). In cases where the 7-yr rotation did not improve soil quality, the fact that the 4-yr rotation receives manure more often may have contributed to higher soil quality in 4-yr plots. Corn biomass was highest in plots receiving the manure treatment and the 7-yr rotation treatment (Corn Biomass 4-yr M: 326g, 4-yr U: 248g, 7-yr M: 436g, 7-yr U: 253g). An interaction was found between manure addition and rotation.

In some instances results show that benefits due to the temporary grass component persist between the first (corn) and last year (kale/cowpea) crop components (e.g. for DA-GMD 7-yr C: $5.1 \mathrm{~mm}, 4-\mathrm{yr} \mathrm{C}: 3.9 \mathrm{~mm}$, and by the end of the cropping cycle the same trend is visible. e.g. 7-yr 
$\mathrm{K}: 4.4 \mathrm{~mm}$, and 4-yr K: 4.3). In other cases, these benefits were not observed (e.g. for P, 7-yr C: $72.9 \mathrm{mg} / \mathrm{kg}, 4-\mathrm{yr} \mathrm{C}: 86.9 \mathrm{mg} / \mathrm{kg}$, and by the end of the cropping cycle the same trend is visible, e.g. 7-yr K: $24.5 \mathrm{mg} / \mathrm{kg}$, and 4-yr K: $29.6 \mathrm{mg} / \mathrm{kg}$ ) or lost by the end of the cropping cycle (e.g. WA-GMD 7-yr C: 4.9mm, 4-yr C: 3.2mm, but by the end of the cropping cycle the trend has reversed 7-yr K: 2.7mm, 4-yr K: 3.0).

Inconsistent weed-management in 2013 corn plots, inconsistent planting density of 2014 corn plots, and the grazing of 7-yr cowpea plots earlier than expected in 2014 all prevented accurate biomass data collection for these plots. For these instances, it was not possible to compare the statistically significant effect of manure and/or rotation cycle on soil quality indicator variables (physical and chemical) to the resulting biomass production. Future researchers have much to gain from studying biomass production associated with soil physical and chemical quality indicators. The importance of consistent management in long term studies should be emphasized.

In the 7-yr rotation, the transition from crops into grass showed an improvement in soil quality (e.g. BD K: 1.14, O5: 1.19; DA-GMD K: 4.4mm, O5: 6.4mm; Calcium K: 1728mg/kg, O5: $2015 \mathrm{mg} / \mathrm{kg}$ ). This improvement was expected to reverse upon reinstatement of cropped plots sequences, and did so in many cases (e.g. BD O7: 1.24, C: 1.13; DA-GMD K: 6.1mm, O5: $5.1 \mathrm{~mm}$; Calcium O7: 2135mg/kg, C: $1938 \mathrm{mg} / \mathrm{kg}$ ). For other properties, an improvement was observed both after the transition into the grass component, and again after the transition back into cropped plots (e.g. Phosphorus K: 27.1mg/kg, O5: 32.0mg/kg, O7: 54.2mg/kg, C: 72.9mg/kg; Potassium K: 125.7mg/kg, O5: 136.3mg/kg, O7: $164.7 \mathrm{mg} / \mathrm{kg}, \mathrm{C}: 188.3 \mathrm{mg} / \mathrm{kg}$ ) This supports the hypothesis that soil physical properties (physical quality/health) improve with the inclusion of a three year grass component into the organic rotation, and that the improvement persists into the first year of cropping.

The results of this research support the use of manure application in an organic crop rotation. The results also support the use of a temporary grass component overall to improve soil physical quality, while it is important that aggregate stability and plant available nutrient pools are most benefitted by a system with regular manure addition. It is interesting that, while nutrient pools were higher in 4-yr plots in many cases, biomass production is ultimately highest in plots receiving the manure and the 7-yr rotation treatment. Because these two practices are Best 
Management Practices, it is suggested that using them in conjunction will yield the best results for soil quality and biomass production.

Results are specific to the management system established in the WVU Certified Organic Farm, however the processes that were addressed may be generalized to organic cropping systems. This research has the ability to better inform decisions about rotational composition and management practices in organic production systems. 


\section{BIBLIOGRAPHY}

Alloway, B.J. 2008. Zinc in Soils and Crop Nutrition. International Zinc Association \& International Fertilizer Association (Ed.), Paris, France.

Aoda, M.I., L. R. Stone, K. W. Kelley and J.A. Hobbs. 1987. Influence of soil amendments and crop rotations on physical properties of a Cherokee silt loam. Transactions of the Kansas Academy of Science, 90:87-95.

Arriaga, F. J, and B. Lowery. 2003. Soil physical properties and crop productivity of an eroded soil amended with cattle manure. Soil Science 168:888-899.

Aslam, T., M. Choudhary, and S. Saggar. 1999. Tillage impacts on soil microbial biomass C, N, and $\mathrm{P}$, earthworms and agronomy after two years of cropping following permanent pasture in New Zealand. Soil and Tillage Research 51:103-111.

Baldwin, K. R. 2006. Organic Production- Crop Rotations on Organic Farms. Center for Environmental Farming Systems Publication, North Carolina Cooperative Extension Service. pp 1-15.

Bell, L. W., B. Sparling, M. Tenuta, and M. H. Entz. 2012. Soil profile carbon and nutrient stocks under long-term conventional and organic crop and alfalfa-crop rotations and reestablished grassland. Agriculture, Ecosystems and Environment 158:156-163.

Bhattacharyya, R., V. Prakash, S. Kundu, and H.S. Gupta. 2006. Effect of tillage and crop rotations on pore size distribution and soil hydraulic conductivity in sandy clay loam soil of the Indian Himalayas. Soil and Tillage Research 86:129-140.

Bird, S., J. Herrick. M. Wander, and S. Wright. 2002. Spatial heterogeneity of aggregate stability and soil carbon in semi-arid rangeland. Environmental Pollution 116:445-455.

Black, C.A. 1965. "Methods of Soil Analysis: Part I Physical and mineralogical properties". American Society of Agronomy, Madison, Wisconsin, USA.

Bronick, C., and R. Lal. 2005. Manuring and rotation effectson soil organic carbon concentration for different aggregate size fractions on two soils in northeastern Ohio, USA. Soil and Tillage Research 81:239-252.

Bulluck. III., L. R., M. Brosius, G. K. Evanylo, and J. B. Ristaino. 2002. Organic and synthetic fertility amendments influence soil microbial, physical and chemical properties on organic and conventional farms. Applied Soil Ecology 19:147-160.

Calegari, A., D. dos Santos Rheinheimer, S. de Touronnet, D. Tessier, W. Hargrove, R. Ralisch,M. de Fatima Guimaraes, and J. Tavares Filho. 2010. Effect of soil management and crop rotation on physical properties in a long term experiment in Southern Brazil. $19^{\text {th }}$ World Congress of Soul Science, Soil Solutions for a Changing World. 1-6 August, Brisbane Australia. Published on DVD.

Carter, M. D., Angers, and H. Kunelius. 1994. Soil Structural Form and stability, and organic matter under cool-season perennial grasses. Soil Sci. Soc. Am. J. 58:1194-1199.

Chan, K.Y., and D.P. Heenan. 1996. The influence of crop rotation on soil structure and soil physical properties under conventional tillage. Soil and Tillage Research 37:113-125. 
Chirinda, N., J. E. Olesen, J. R. Porter, and P. Schjonning. 2010. Soil properties, crop production and greenhouse gas emissions from organic and inorganic fertilizer-based arable cropping systems. Agriculture, Ecosystems and Environment 139:584-594.

Clark, M. S., W. R. Horwath, C. Shennan, and K. M. Scow. 1998. Changes in soil chemical properties resulting from organic and low-input farming practices. Agron. J. 90:662-671.

Diaz-Zorita, M., E. Perfect, and J. H. Grove. 2002. Disruptive methods for assessing soil structure. Soil \& Tillage Research 64:3-22.

Drinkwater, L. E., P. Wagoner, and M. Sarrantonio. 1998. Legume-based cropping systems have reduced carbon and nitrogen losses. Nature 396:262-265.

Duiker, S. W. 2006. Soil Management: Chapter 6, Mid-Atlantic Nutrient Management Handbook. Regional Water Program. 127-150.

Eck, H. V. 1986. Effects of water deficits on yield, yield components, and water-use efficiency of irrigated corn. Agronomy Journal 78:1035-1040.

Eghball, B. 2002. Soil Properties as Influenced by Phosphorus- and Nitrogen-Based Manure and Compost Applications. Agronomy Journal. 94:128-135

Entz, M. H., W. J. Bullies, and F. Katepa-Mupondwa. 1995. Rotational benefits of forage crops in Canadian prairie cropping systems. Journal of Production Agriculture 8:521-29

Feng, G., B. Sharratt, and F. Young. 2011. Influence of long-term tillage and crop rotations on soil hydraulic properties in the US Pacific Northwest. Journal of Soil and Water Conservation 66:4, 233-241.

Gadermaier, F., A. Berner, A. Fliesbach, J. K. Friedel, and P. Mader. 2011. Impact of reduced tillage on soil organic carbon and nutrient budgets under organic farming. Renewable Agriculture and Food Systems. pp 1-13.

Green, V. S., M. A. Cavigelli, T. H. Dao, and D. C. Flanagan. 2005. Soil physical properties and aggregate-associated $\mathrm{C}, \mathrm{N}$, and $\mathrm{P}$ distributions in organic and conventional cropping systems. Soil Science 170:822-831.

Guo, Z., G. Yan, R. Zhang, G. Li, Z. Zeng, and H. Liu. 2010. Improvement of Soil Physical Properties and Aggregate-Associated C, N, and P after cropland was converted to grassland in semiarid loess plateau. Soil Science 175:99-104.

Haberl, H., K. Heinz Erb, F. Krausmann, V. Gaube, A. Bondeau, C. Plutzar, S. Gingrich, W. Lucht, and M. Fischer-Kowalski. 2007. Quantifying and mapping the human appropriation of net primary production in earth's terrestrial ecosystems. PNAS 104:31.

Harmoney, K. R., K. J. Moore, J. R. George, E. C. Brummer, and J. R. Russell. 1997. Determination of pasture biomass using four indirect methods. Agronomy Journal 89:665672.

Hati, K.M., A. Swarup, A.K. Dwivedi, A.K. Misra, K. and K. Bandyopadhyay. 2007. Changes in soil physical properties and organic carbon status at the topsoil horizon of a vertisol of central India after 28 years of continuous cropping, fertilization, and manuring. Agriculture, Ecosystems and Environment 119:127-134. 
Haynes, R.J., and R. Naidu. 1998. Influence of lime, fertilizer and manure applications on soil organic matter content and soil physical conditions: a review. Agroecosystems 51:123 $-137$

Jat, R. A., S. P. Wani, and K. L. Sahrawat. 2012. Conservation agriculture in the semi-arid tropics: prospects and problems. Advances in Agronomy, Chapter Four. 117:191-272.

Kalra, Y.P. 1995. Determination of $\mathrm{pH}$ of soils by different methods: collaborative study. Journal of the Association Off. Analytical Chemistry International 78:310-321.

Klute, A. and C. Jacob. 1949. Physical properties of Sassafras silt loam as affected by long-time organic matter additions. Soil Science Society Proceedings. pp 24-28.

Leco, 2003. Total/organic carbon and nitrogen in soils. LECO Corporation, St. Joseph, MO, Organic Application Note 203-821-165

Liebman, M., and A.S. Davis. 2000. Integration of soil, crop and weed management in lowexternal-input farming systems. Weed Research: 40:27-47.

Luo, Z, E. Wang, and O. J. Sun. 2010. Soil carbon change and its responses to agricultural practices in Australian agro-ecosystems: a review and synthesis. Geoderma 155:211-223.

Mäder, P., A. Fliesbach, D. Dubois, L. Gunst, P. Fried, and U. Niggli. 2002. Soil fertility and biodiversity in organic farming. Science 296:1694-1697.

McIntosh, J. L., and K. E. Varney. 1973. Accumulative effects of manure and $\mathrm{N}$ on continuous corn and clay soil. II Chemical changes in soil. Agronomy Journal, 65:629-633.

McMaster, G. S., and W. W. Wilhelm. 1997. Growing degree-days: one equation, two interpretations. Agricultural and Forest Meteorology 87:291-300.

Mehlich, A. 1984. Mehlich-3 soil test extractant: a modification of Mehlich-2 extractant. Commun. Soil Sci. Plant Analysis 15(12):1409-1416.

Nelson, D.W., and L.E. Sommers. 1996. Total Carbon, Organic Carbon, and Organic Matter. p. 961-1010. In D.L. Sparks (ed.) Methods of Soil Analysis. Part 3. Chemical Methods. Soil Science Society of America Book Ser. 5. SSSA and ASA, Madison, Wis.

NOAA. 2006. National Weather Service Forecast Office. Access Date 30 April 30, 2013. http://www.nws.noaa.gov/climate/xmacis.php?wfo=pbz

NRAES (National Resource, Agriculture, and Engineering Service) 177, Charles L. Mohler and Sue Ellen Johnson, editors. 2009. Crop Rotation on Organic Farms- Planning Manual.

Ominski, P. D., M. H. Entz, and N. Kenkel. 1999. Weed suppression by Medicago sativa in subsequent cereal crops: A comparative survey. Weed Science 47:282-90.

Pimentel, D., P. Hepperly, J Hanson, D. Douds, and R. Seidel. 2005. Environmental, energetic, and economic comparisons of organic and conventional farming systems. Bioscience 55:7, 573-582.

Pucheta, E., I. Bonamici, M. Cabido, and S. Diaz. 2004. Below-ground biomass and productivity of a grazed site and a neighboring ungrazed exclosure in a grassland in central Argentina. Aust. Ecol. 29:2001-2008. 
Rachman, A. S. Anderson, C. Gantzer, and A. Thompson. 2003. Influence of Long-term cropping systems on soil physical properties related to soil erodibility. Soil Sci. Soc. Am. Journal 67:637-644.

Rayburn, E.B., and S.B. Rayburn. 1998. A standardized plate meter for estimating pasture mass in on-farm research trials. Agronomy Journal 90:238-241.

Reeder, J. D., and G. E. Schuman. 2002. Influence of livestock grazing on C sequestration in semi-arid mixed grass and short grass rangelands. Environ. Pollut. 116:457-463.

Reeves, D. W. 1994. Cover crops and rotations. USDA, CRC Press, Inc. 125-172.

Riley, H., R. Pommeresche, R. Eltun, S. Hansen, and A. Korsaeth. 2008. Soil structure, organic matter, and earthworm activity in a comparison of cropping systems with contrasting tillage, rotations, fertilizer levels, and manure use. Agriculture Ecosystems and Environment 124:275-284.

Robertson, G. P., E. A. Paul, and R. R. Harwood. 2000. Greenhouse gases in intensive agriculture: contributions of individual gases to the radiative forcing of the atmosphere. Science 289:1922-1925.

Sainju, U. M., W. F. Whitehead, and B. P. Singh. 2003. Cover crops and nitrogen fertilization effects on soil aggregation and carbon and nitrogen pools. Canadian Journal of Soil Science. 155-165.

Sala, O. E., and A. T. Austin, 2000. Chapter 2: Methods of Estimating Aboveground Net Primary Productivity. P. 31-43. In Methods in Ecosystem Science, O. E. Sala, R. B. Jackson, H. A. Mooney, and R. H. Howarth (eds) Springer, New York.

SAS Institute Inc. 2009. SAS/STAT 9.2 User's Guide, Second Edition: Statistics 6th ed. Vol. 2. SAS Institute Inc., Cary, NC, USA.

Schjonning, P., B. Christensen, and B. Carstensen. 1994. Physical and chemical properties of a sandy loam receiving animal manure, mineral fertilizer or no fertilizer for 90 years. European Journal of Soil Science 45:3, 257-268.

Shirani, H., M. Hajabbasi, M. Afyuni, and A. Hemmat. 2002. Effects of farmyard manure and tillage systems on soil physical properties and orn yield in central Iran. Soil \& Tillage Research 68:101-108.

Siegrist, S., D. Schaub, L. Pfiffner, and P. Mäder. 1998. Does organic agriculture reduce soil erodibility? The results of a long-term field study on loess in Switzerland. Agriculture, Ecosystems and Environment 69:253-264.

Sims, G. K. 1990. Biological degradation of soil. Advances in Soil Science 11:289-330.

Six, J. G. Guggenberger, K. Paustian, L. Haumaier, E. T. Elliott, and W. Zech. 2001. Sources and composition of soil organic matter fractions between and within soil aggregates. European Journal of Soil Science, 52:607-618.

Slepetiene, A., I. Liaudanskiene, J. Slepetys, and A. Velykis. 2010. The influence of reduced tillage, winter crops and ecologically managed long-term mono- and multi-component swards on soil humic substances. Chemistry and Ecology, Supplement, 26:97-109. 
Soussana, J.F., P. Loiseau, N. Vuichard, E. Ceschia, J. Balesdent, T. Chevallier, and D. Arrouays. 2004. Carbon cycling and sequestration opportunities in temperate grasslands. Soil Use Management. 20:219-230.

Stoddard, C.S., M. S. Coyne, J. H. Grove. 1998. Fecal Baterial Survival and Infiltration through a Shallow Agricultural Soil: Timing and Tillage Effects. Journal of Environmental Quality. 27:1516-1523.

Tisdall, J., and J. Oades. 1979. Stabilisation of soil aggregates by the root systems of ryegrass Aust. J. Soil Res., 17:429-441.

Uhland, R. E. 1949. Physical properties of soil as modified by crops and management. Soil Sci. Soc. Am. Proc. 14:361-366.

USDA, National Institute of Food and Agriculture. 2009. Legal Definition of Sustainable Agriculture.http://www.csrees.usda.gov/nea/ag_systems/in_focus/sustain_ag_if_legal.html

Van Oost, K., G. Govers, S. de Alba, and T.A. Quine. 2006. Tillage erosion: a review of controlling factors and implications for soil quality. Progress in Physical Geography 30: 443-466.

Walker, D. J., R. Clemente, and M. P. Bernal. 2004. Contrasting effects of manure and compost on soil $\mathrm{pH}$, heavy metal availability and growth of Chenopodium album L. in a soil contaminated by pyritic mine waste. Chemosphere 57:215-224;

Web Soil Survey. 2012. USDA, NRCS. http://websoilsurvey.nrcs.usda.gov/app/HomePage.htm West, T. O., and W. M. Post. 2002. Soil organic carbon sequestration rates by tillage and crop rotation: A global data analysis. Division S-6- Soil and Water Management and Conservation. Soil Sci. Soc. Am. J. 66:1930-1946.

Whalen, J.K., C. Chang, G. W. Clayton, and J. P. Carefoot. 2000. Cattle Manure Amendments Can Increase the pH of Acid Soils. Soil Sci. Soc. Am. J. 64:962-966

White, R.E. 2006. Ch 11 and 15. In Principles and Practice of Soil Science: The Soil as a Natural Resource; Fourth Edition. Blackwell Publishing.

Wortmann, C. S., and P. J. Jasa. 2009. Management to Minimize and Reduce Soil Compaction. University of Nebraska-Lincoln Extension NebGuide; G896. Institute of Agriculture and Natural Resources.

Yamashita, T., H. Flessa, B. John, M. Helfrich, and B. Ludwig. 2006. Organic matter in density fractions of water-stable aggregates in silty soils: Effect of land use. Soil Biology and Biochemistry. 38:3222-3234.

Yoder, R.E. 1936. A direct method of aggregate analysis of soils and a study of the physical nature of erosion losses. J. Am. Soc. Agron. 28:337-351.

Young, R. A., J. C. Zubriski, and E. B. Norum. 1960. Influence of long-time fertility management practices on chemical and physical properties of a Fargo clay. Soil Science Society Proceedings. 124-128. 


\section{Appendix A}

Table A1. Summary of surface soil properties $(0-15 \mathrm{~cm})$ in the study area by map unit

\begin{tabular}{|c|c|c|c|c|c|c|c|c|}
\hline Soil Unit & Texture & $\begin{array}{c}\text { Slope } \\
\%\end{array}$ & $\begin{array}{l}\text { Capability } \\
\text { Class }\end{array}$ & SOM \% & pH & $\underset{\mathrm{Mg} / \mathrm{m}^{3}}{\text { BD }}$ & $\begin{array}{c}\text { CEC } \\
\text { meq/10 } \\
0 \mathrm{~g}\end{array}$ & $\begin{array}{c}\mathbf{K}_{\text {sat }} \\
\mathrm{cm} / \mathrm{min}\end{array}$ \\
\hline CwE & Silt loam & $25-35$ & $6 e$ & $3.0-5.0$ & $5.1-6.0$ & $1.20-1.40$ & $19-21$ & $\begin{array}{c}0.024- \\
0.252\end{array}$ \\
\hline DgB & Silt loam & $3-8$ & $2 \mathrm{e}$ & $1.0-4.0$ & $4.5-6.0$ & $1.20-1.40$ & $9.0-20$ & $\begin{array}{c}0.024- \\
0.084\end{array}$ \\
\hline DgC & Silt loam & $8-15$ & $3 e$ & $1.0-4.0$ & $4.5-6.0$ & $1.20-1.40$ & $9.0-20$ & $\begin{array}{c}0.024- \\
0.084\end{array}$ \\
\hline DgD & Silt loam & $15-25$ & $4 \mathrm{e}$ & $1.0-4.0$ & $4.5-6.0$ & $1.20-1.40$ & $9.0-20$ & $\begin{array}{c}0.024- \\
0.084\end{array}$ \\
\hline TIB & Silt loam & $3-8$ & $2 \mathrm{e}$ & $2.0-4.0$ & $3.6-5.5$ & $1.20-1.60$ & $8.0-13$ & $\begin{array}{c}0.024- \\
0.084\end{array}$ \\
\hline
\end{tabular}
Source: (Web Soil Survey, 2012)

Table A2: Scanned field map, bird's eye view of 2014 planting

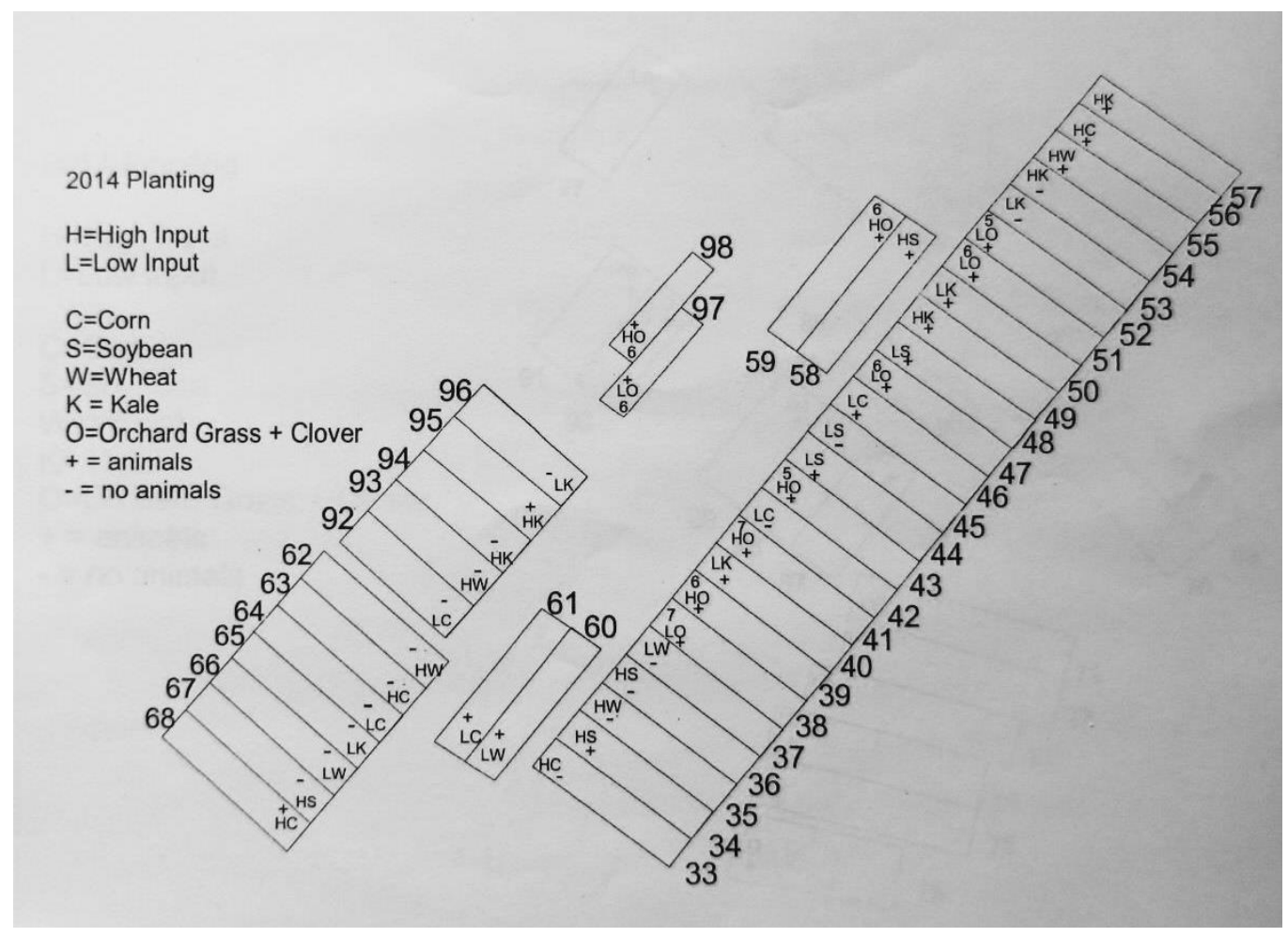


Table A2a: Scanned field map (continued), bird's eye view of 2014 planting

2014 Planting

$\mathrm{H}=$ High Input

L=Low Input

$\mathrm{C}=$ Corn

$\mathrm{S}=$ Soybean

$W=$ Wheat

$\mathrm{K}=$ Kale

$\mathrm{O}=$ Orchard Grass + Clover

$+=$ animals

- = no animals
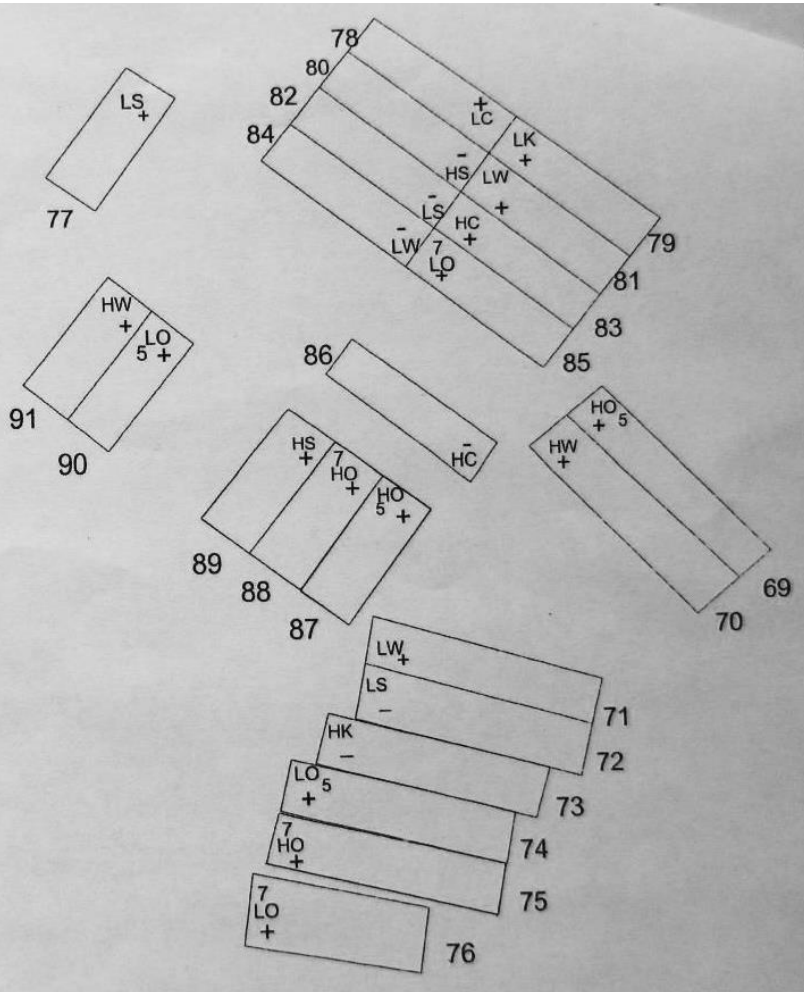

These field maps show crops for the 2014 planting season.

Manure input is indicated as High $(\mathrm{H})=$ manured, and Low $(\mathrm{L})=$ unmanured.

Orchardgrass plots are denoted as "O" with the year in grass indicated $(5,6$, or 7$)$.

"+=animals" indicates the 7-year rotation (the orchardgrass plots are grazed twice per year for approximately one day.

“- = no animals" indicates the 4-yr rotation. These plots are never grazed.

Table A2b: Rotational Cycles, 4-yr and 7-yr
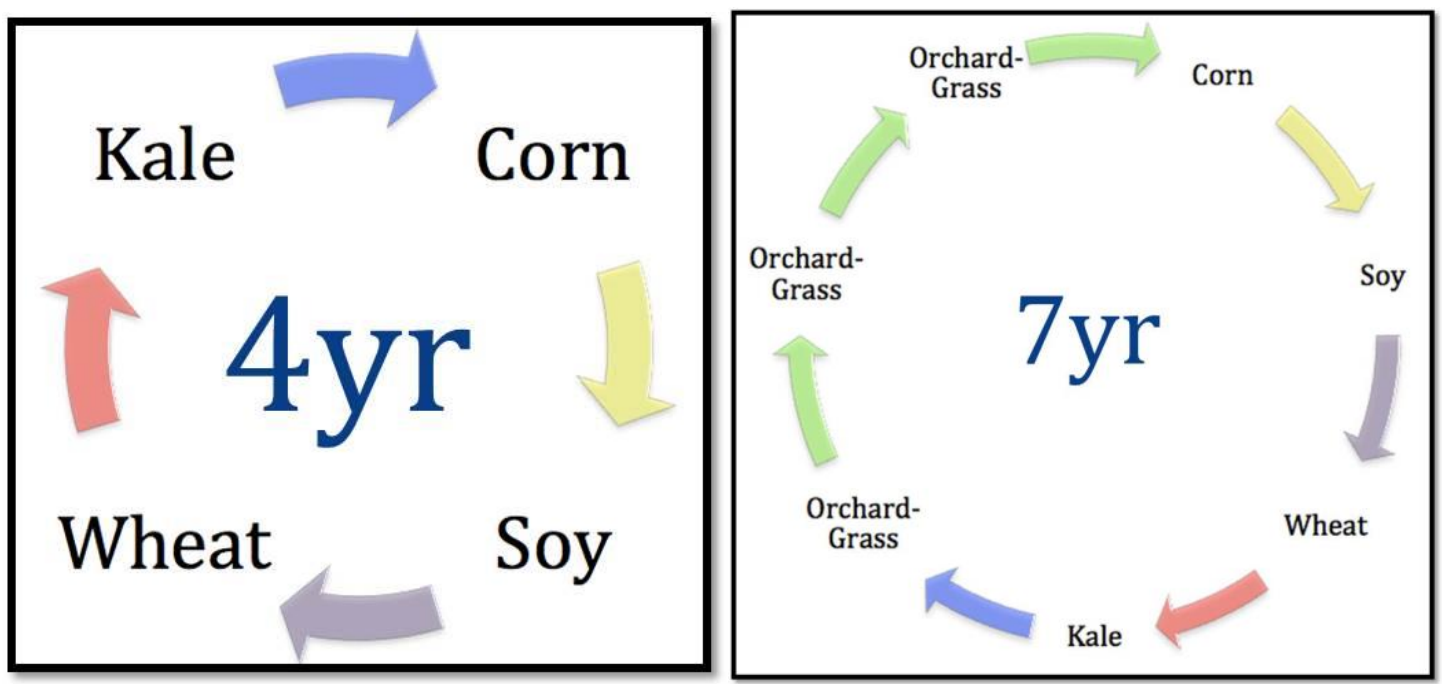
Table A3: Varieties of all planted crops:

\begin{tabular}{|l|l|l|}
\hline Crop & Variety Name & Source Company \\
\hline Corn & $\begin{array}{l}\text { N659 2000-2011 } \\
\text { 48B30 in 2012 and 2013 }\end{array}$ & Blue River Hybrids \\
\hline Soybean & 34A7 & Blue River Hybrids \\
\hline Wheat & WS44 (soft red winter wheat) & Welter Seed Co. \\
\hline Kale & "Premier" & Southern States \\
\hline Cowpea & "Iron and Clay" & Johnny Seeds \\
\hline Winter Rye & VNS* & Welter Seed Co. \\
\hline Hairy Vetch & VNS* & Albert Lee Seed Co. \\
\hline $\begin{array}{l}\text { Orchardgrass } \\
\text { (18-40lbs/ac) }\end{array}$ & "Niva" & Welter Seed Co. \\
\hline $\begin{array}{l}\text { Red Clover } \\
(10 \text { lbs/ac) }\end{array}$ & "Red Star" & Welter Seed Co. \\
\hline
\end{tabular}

$$
\text { *VNS }=\text { Variety Not Stated }
$$

Table A4: Plant Available Nutrient Laboratory Analysis Report Information

\begin{tabular}{|c|c|c|c|c|}
\hline $\begin{array}{c}\text { Date of } \\
\text { Analysis }\end{array}$ & $\begin{array}{c}\mathbf{N} \text { (Surface } \\
\text { available) } \\
\text { (lbs/ton) }\end{array}$ & $\begin{array}{c}\mathbf{N} \\
\text { (Incorporated) } \\
\text { (lbs/ton) }\end{array}$ & $\begin{array}{c}\text { Phosphate } \\
\left(\mathbf{P}_{\mathbf{2}} \mathbf{O}_{\mathbf{5}} \text { ) } \text { (lbs/ton) }\right.\end{array}$ & $\begin{array}{c}\text { Potash }\left(\mathbf{K}_{\mathbf{2}} \mathbf{O}\right) \\
\text { (lbs/ton) }\end{array}$ \\
\hline $6-16-2011$ & 4.96 & 5.52 & 7.38 & 15.44 \\
\hline $12-9-2010$ & 7.03 & 8.28 & 18.81 & 18.33 \\
\hline $6-25-2010$ & 4.17 & 0.17 & 13.98 & 7.08 \\
\hline $10-5-2009$ & 5.94 & 2.26 & 10.10 & 16.84 \\
\hline $4-14-2009(1)$ & 2.73 & 0.97 & 10.41 & 12.64 \\
\hline $4-14-2009(2)$ & 3.49 & 1.43 & 9.97 & 9.80 \\
\hline $10-2-2008$ & 3.70 & 1.72 & 14.73 & 9.89 \\
\hline
\end{tabular}

Provided for William Bryan, WVU, by: WVDA Nutrient Management Lab

Moorefield Field Office

60B Industrial Park Road

Moorefield WV 26836

(304) 538-2397 


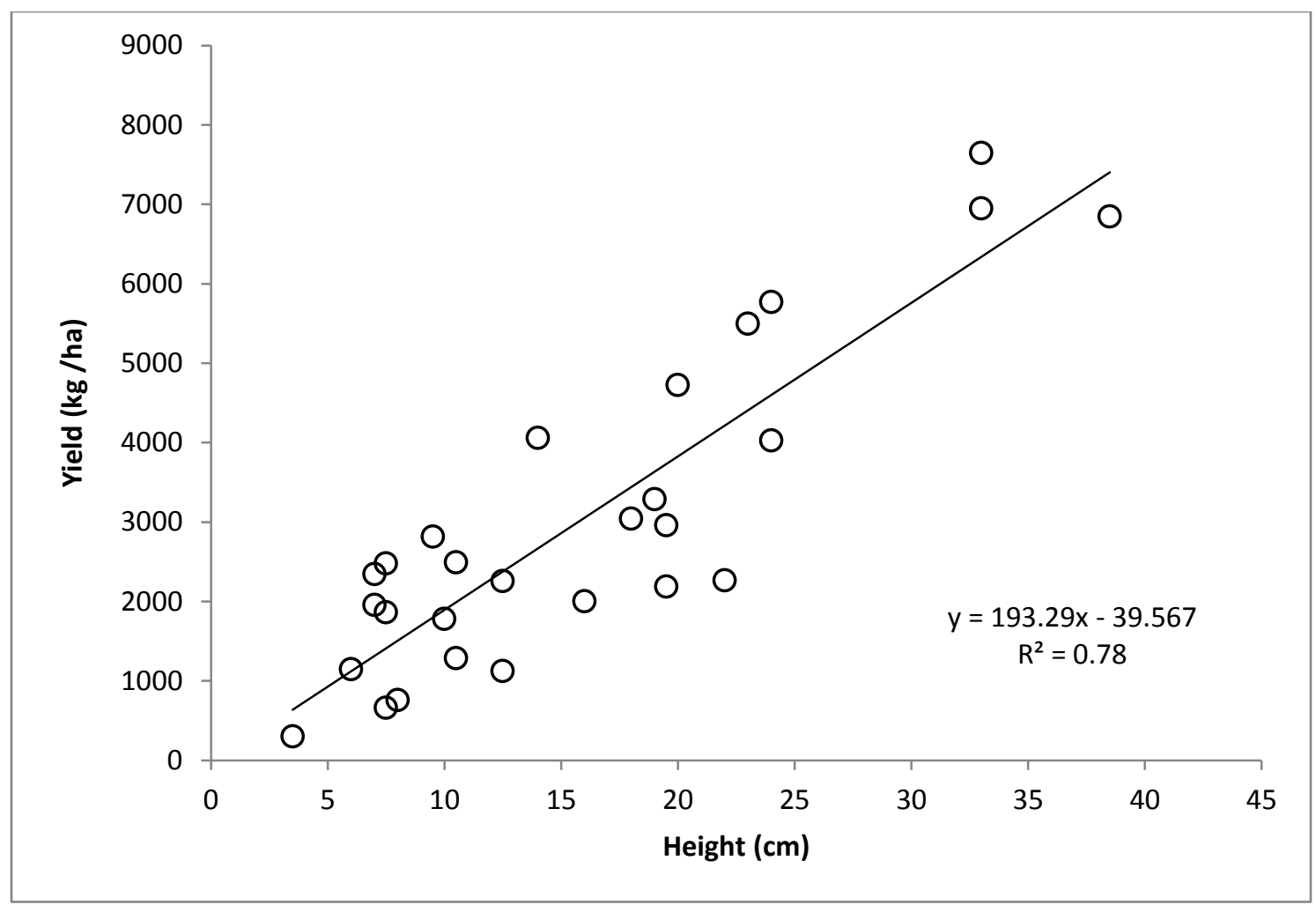

Figure A1: Calibration curve to estimate grass component biomass.

\section{Appendix B}

Overall Means for 2013, Experiment 1: physical and chemical variables measured: Table B1a

\begin{tabular}{|c|c|c|c|c|}
\hline Variable & Overall Mean & Std Dev & Min & Max \\
\hline BD $\left(\mathrm{Mg} / \mathrm{m}^{3}\right)$ & 1.18 & 1.12 & 0.91 & 1.479 \\
\hline SOM $(\%)$ & 4.1 & 1.1 & 2.3 & 7.6 \\
\hline MWDdry $(\mathrm{mm})$ & 8.2 & 3.4 & 3.0 & 45.1 \\
\hline GMDdry $(\mathrm{mm})$ & 5.3 & 2.1 & 1.3 & 11.2 \\
\hline MWDwet $(\mathrm{mm})$ & 5.2 & 1.0 & 1.5 & 6.3 \\
\hline GMDwet $(\mathrm{mm})$ & 4.2 & 1.4 & 0.7 & 6.2 \\
\hline
\end{tabular}

Table B1b

\begin{tabular}{|c|c|c|c|c|}
\hline Variable & Overall Mean & Std Dev & Min & Max \\
\hline Phos_mg/kg & 35.5 & 37.6 & 2.0 & 218.5 \\
\hline $\mathrm{K} \_\mathrm{mg} / \mathrm{kg}$ & 114.4 & 54.6 & 37.0 & 368.5 \\
\hline $\mathrm{pH} \_\mathrm{KCl}$ & 5.4 & 0.6 & 3.4 & 6.8 \\
\hline $\mathrm{pH} \_$buffer & 7.1 & 0.2 & 5.5 & 7.41 \\
\hline $\mathrm{Ca} \_\mathrm{mg} / \mathrm{kg}$ & 1844.1 & 654.6 & 176.0 & 4670.0 \\
\hline $\mathrm{Mg} \_\mathrm{mg} / \mathrm{kg}$ & 136.2 & 46.1 & 45.0 & 336.0 \\
\hline
\end{tabular}




\begin{tabular}{|c|c|c|c|c|}
\hline $\mathrm{Zn} \_\mathrm{mg} / \mathrm{kg}$ & 3.5 & 2.5 & 0.5 & 24.7 \\
\hline $\mathrm{OM}(\%)$ & 3.5 & 1.3 & 1.1 & 8.4 \\
\hline $\mathrm{TotN}(\mathrm{g} / \mathrm{kg})$ & 1.9 & 0.7 & 0.6 & 4.3 \\
\hline
\end{tabular}

Overall Means for 2014, Experiment 1: physical and chemical variables measured:

Table B1c

\begin{tabular}{|c|c|c|c|c|}
\hline Variable & Overall Mean & Std Dev & Min & Max \\
\hline BD $\left(\mathrm{Mg} / \mathrm{m}^{3}\right)$ & 1.20 & 1.01 & 0.97 & 1.42 \\
\hline SOM $(\%)$ & 3.6 & 1.5 & 1.1 & 8.7 \\
\hline MWDdry $(\mathrm{mm})$ & 9.9 & 2.0 & 5.0 & 14.2 \\
\hline GMDdry $(\mathrm{mm})$ & 2.3 & 0.3 & 1.5 & 3.0 \\
\hline MWDwet $(\mathrm{mm})$ & 5.4 & 0.8 & 2.7 & 6.2 \\
\hline GMDwet $(\mathrm{mm})$ & 4.4 & 1.1 & 1.1 & 5.8 \\
\hline
\end{tabular}

Table B1d

\begin{tabular}{|c|c|c|c|c|}
\hline Variable & Overall Mean & Std Dev & Min & Max \\
\hline Phos_mg/kg & 36.2 & 45.2 & 1.0 & 246.0 \\
\hline K_mg/kg & 145.1 & 95.3 & 29.0 & 462.0 \\
\hline pH_KCl & 6.7 & 0.5 & 5.5 & 7.7 \\
\hline pH_buffer & 7.2 & 0.1 & 6.7 & 7.4 \\
\hline Ca_mg/kg & 1751.3 & 686.6 & 640.0 & 4680 \\
\hline Mg_mg/kg & 149.4 & 56.1 & 37.0 & 311.0 \\
\hline Zn_mg/kg & 4.2 & 4.1 & 0.6 & 31.8 \\
\hline OM $(\%)$ & 3.6 & 1.5 & 1.1 & 8.7 \\
\hline TotN $(\mathrm{g} / \mathrm{kg})$ & 2.0 & 0.7 & 0.74 & 4.4 \\
\hline
\end{tabular}

Table B1e: Corn biomass overall means 2014, plant-based values

\begin{tabular}{|l|c|c|c|c|}
\hline $\begin{array}{l}\text { Corn Biomass } \\
\text { Metrics }\end{array}$ & $\begin{array}{l}\text { Stalk Biomass } \\
\text { by plant }(\mathrm{g})\end{array}$ & $\mathrm{g} /$ Ear & $\begin{array}{l}\text { Kernels only, by } \\
\text { plant }(\mathrm{g})\end{array}$ & $\begin{array}{l}\text { Total Biomass per plant } \\
\text { (Stalks, cobs, and kernels }) \\
(\mathrm{g})\end{array}$ \\
\hline & $176.1 \pm 35.3$ & $152.8 \pm 51.0$ & $115.8 \pm 36.0$ & $315.7 \pm 69.9$ \\
\hline
\end{tabular}

Table B2a: Mean weight diameter data for 2013

\begin{tabular}{|r|c|c|}
\hline \multicolumn{2}{|c|}{2013 DA-MWD } & B = 7-yr \\
\hline \multicolumn{1}{|c|}{ Treatment } & A=4-yr & \\
\hline Composted Manure & & $8.4 \mathrm{a}$ \\
\hline $\mathrm{M}$ & $6.1 \mathrm{~b}$ & $7.8 \mathrm{a}$ \\
\hline $\mathrm{U}$ & $7.5 \mathrm{a}$ & \\
\hline & & $7.9 \mathrm{a}$ \\
\hline Crop & & $8.2 \mathrm{a}$ \\
\hline $\mathrm{C}$ & $6.6 \mathrm{a}$ & \\
\hline $\mathrm{K}$ & $7.0 \mathrm{a}$ & \\
\hline & & \\
\hline
\end{tabular}




\begin{tabular}{|r|c|c|}
\hline \multicolumn{1}{|l|}{ Manure*Crop } & \multicolumn{2}{|c|}{} \\
\hline $\mathrm{C} * \mathrm{M}$ & $5.6 \pm 2.1$ & $8.4 \pm 1.8$ \\
\hline $\mathrm{K} * \mathrm{M}$ & $6.7 \pm 1.3$ & $8.4 \pm 1.5$ \\
\hline $\mathrm{C} * \mathrm{U}$ & $7.7 \pm 1.5$ & $7.5 \pm 1.3$ \\
\hline $\mathrm{K} * \mathrm{U}$ & $7.3 \pm 2.1$ & $8.1 \pm 2.7$ \\
\hline & \multicolumn{2}{|c|}{ Pr>F } \\
\hline Grand Mean & 0.0007 & 0.7894 \\
\hline Block & 0.0016 & 0.6841 \\
\hline Composted Manure & 0.4052 & 0.8363 \\
\hline Crop & 0.0704 & 0.8302 \\
\hline Manure*Crop & &
\end{tabular}

*Letters show significance at $\alpha=0.1$ within column.

\begin{tabular}{|c|c|c|}
\hline \multicolumn{3}{|c|}{2013 DA-MWD $(\mathrm{mm})$} \\
\hline Treatment & Corn & Kale \\
\hline \multicolumn{3}{|l|}{ Composted Manure } \\
\hline $\mathrm{M}$ & $7.0 \mathrm{a}$ & $7.5 \mathrm{a}$ \\
\hline $\mathrm{U}$ & $7.6 \mathrm{a}$ & $7.7 \mathrm{a}$ \\
\hline \multicolumn{3}{|l|}{ Rotation Cycle } \\
\hline $4-\mathrm{yr}$ & $6.6 \mathrm{~b}$ & $7.0 \mathrm{a}$ \\
\hline $7-\mathrm{yr}$ & $7.9 \mathrm{a}$ & $8.2 \mathrm{a}$ \\
\hline \multicolumn{3}{|l|}{ Manure*Rotation } \\
\hline $\mathrm{M} * 4-\mathrm{yr}$ & $5.6 \pm 2.1$ & $6.7 \pm 1.3$ \\
\hline$M * 7-y r$ & $8.4 \pm 1.8$ & $8.4 \pm 1.5$ \\
\hline $\mathrm{U}^{* 4-\mathrm{yr}}$ & $7.7 \pm 1.5$ & $7.3 \pm 2.1$ \\
\hline $\mathrm{U}^{* 7-\mathrm{yr}}$ & $7.5 \pm 1.3$ & $8.1 \pm 2.7$ \\
\hline Grand Mean & 7.2 & 7.6 \\
\hline & \multicolumn{2}{|c|}{$\operatorname{Pr}>F$} \\
\hline Block & 0.0072 & 0.4615 \\
\hline Composted Manure & 0.1393 & 0.9109 \\
\hline Rotation & 0.0022 & 0.3876 \\
\hline Rotation*Crop & 0.0004 & 0.7601 \\
\hline
\end{tabular}

*Letters show significance at $\alpha=0.1$ within column.

\begin{tabular}{|c|c|c|}
\hline \multicolumn{3}{|c|}{2013 WA-MWD } \\
\hline Treatment & $\mathrm{A}=4-\mathrm{yr}$ & $B=7-y r$ \\
\hline \multicolumn{3}{|l|}{ Composted Manure } \\
\hline $\mathrm{M}$ & $5.1 \mathrm{a}$ & $5.0 \mathrm{a}$ \\
\hline$\overline{\mathrm{U}}$ & $4.0 \mathrm{~b}$ & $4.8 \mathrm{a}$ \\
\hline \multicolumn{3}{|l|}{ Crop } \\
\hline $\bar{C}$ & $4.5 \mathrm{a}$ & $5.8 \mathrm{a}$ \\
\hline $\mathrm{K}$ & $4.5 \mathrm{a}$ & $4.1 \mathrm{~b}$ \\
\hline Manure*Crop & & \\
\hline
\end{tabular}




\begin{tabular}{|r|c|c|}
\hline $\mathrm{C}^{*} \mathrm{M}$ & $5.1 \pm 0.5$ & $5.8 \pm 0.3$ \\
\hline $\mathrm{K}^{*} \mathrm{M}$ & $5.0 \pm 0.5$ & $4.2 \pm 0.9$ \\
\hline $\mathrm{C}^{*} \mathrm{U}$ & $3.8 \pm 1.5$ & $5.7 \pm 0.5$ \\
\hline $\mathrm{K}^{*} \mathrm{U}$ & $4.1 \pm 0.9$ & $3.9 \pm 0.8$ \\
\hline & \multicolumn{2}{|c|}{$\mathrm{Pr}>\mathrm{F}$} \\
\hline Grand Mean & 4.5 & 4.9 \\
\hline & \multicolumn{2}{|c|}{0.0287} \\
\hline Block & 0.3123 & 0.4208 \\
\hline Composted Manure & $<.0001$ & $<.0001$ \\
\hline Crop & 0.8595 & 0.5909 \\
\hline Manure*Crop & 0.4778 &
\end{tabular}

*Letters show significance at $\alpha=0.1$ within column.

\begin{tabular}{|c|c|c|}
\hline \multicolumn{3}{|c|}{2013 WA: MWD (mm) } \\
\hline Treatment & Corn & Kale \\
\hline \multicolumn{3}{|l|}{ Composted Manure } \\
\hline 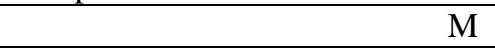 & $5.5 \mathrm{a}$ & $4.6 \mathrm{a}$ \\
\hline $\mathrm{U}$ & $4.8 \mathrm{~b}$ & $4.0 \mathrm{~b}$ \\
\hline \multicolumn{3}{|l|}{ Rotation Cycle } \\
\hline $4-y r$ & $4.5 b$ & $4.5 \mathrm{a}$ \\
\hline $7-\mathrm{yr}$ & $5.8 \mathrm{a}$ & $4.1 b$ \\
\hline \multicolumn{3}{|l|}{ Manure*Rotation } \\
\hline M*4-yr & $5.1 \pm 0.5$ & $5.0 \pm 0.5$ \\
\hline M*7-yr & $5.8 \pm 0.3$ & $4.2 \pm 0.8$ \\
\hline $\mathrm{U} * 4-\mathrm{yr}$ & $3.8 \pm 1.5$ & $4.1 \pm 0.9$ \\
\hline $\mathrm{U} * 7-\mathrm{yr}$ & $5.7 \pm 0.5$ & $3.9 \pm 0.8$ \\
\hline Grand Mean & 5.1 & 4.3 \\
\hline & \multicolumn{2}{|c|}{$\operatorname{Pr}>F$} \\
\hline Block & 0.1853 & 0.0475 \\
\hline Composted Manure & 0.0024 & 0.0032 \\
\hline Rotation & $<.0001$ & 0.0160 \\
\hline Rotation*Crop & 0.0091 & 0.0733 \\
\hline
\end{tabular}

*Letters show significance at $\alpha=0.1$ within column.

Table B2b: Mean weight diameter data for 2014

\begin{tabular}{|c|c|c|}
\hline \multicolumn{3}{|c|}{2014 DA-MWD } \\
\hline Treatment & $\mathrm{A}=4-\mathrm{yr}$ & $\mathrm{B}=7-\mathrm{yr}$ \\
\hline Composted Manure & & \\
\hline M & $10.2 \mathrm{a}$ & $9.6 \mathrm{a}$ \\
\hline $\mathrm{U}$ & $10.0 \mathrm{a}$ & $9.9 \mathrm{a}$ \\
\hline Crop & & \\
\hline $\mathrm{C}$ & $11.6 \mathrm{a}$ & $10.5 \mathrm{a}$ \\
\hline $\mathrm{K}$ & $8.6 \mathrm{~b}$ & $8.9 \mathrm{~b}$ \\
\hline Manure*Crop & & \\
\hline
\end{tabular}




\begin{tabular}{|r|c|c|}
\hline $\mathrm{C} * \mathrm{M}$ & $11.3 \pm 1.5$ & $9.8 \pm 1.6$ \\
\hline $\mathrm{K} * \mathrm{M}$ & $9.1 \pm 1.7$ & $9.4 \pm 0.9$ \\
& & $11.4 \pm 1.7$ \\
\hline $\mathrm{C} * \mathrm{U}$ & $12.0 \pm 1.3$ & $8.5 \pm 1.3$ \\
\hline & $8.1 \pm 2.6$ & \\
\hline & & 9.7 \\
\hline Grand Mean & 10.1 & \multicolumn{2}{|c|}{ Pr>F } \\
\hline Block & 0.0012 & 0.8521 \\
\hline Crop & $<.0001$ & $<.0001$ \\
\hline Composted Manure & 0.6603 & 0.3693 \\
\hline Manure*Crop & 0.0368 & 0.0009 \\
\hline
\end{tabular}

*Letters show significance at $\alpha=0.1$ within column.

\begin{tabular}{|c|c|c|}
\hline \multicolumn{3}{|c|}{2014 DA-MWD (mm) } \\
\hline Treatment & Corn & Kale \\
\hline \multicolumn{3}{|l|}{ Composted Manure } \\
\hline $\bar{M}$ & $10.6 \mathrm{~b}$ & $9.2 \mathrm{a}$ \\
\hline $\mathrm{U}$ & $11.7 \mathrm{a}$ & $8.3 \mathrm{~b}$ \\
\hline \multicolumn{3}{|l|}{ Rotation Cycle } \\
\hline $4-y r$ & $11.6 \mathrm{a}$ & $8.6 \mathrm{a}$ \\
\hline $7-\mathrm{yr}$ & $10.6 \mathrm{~b}$ & $8.9 \mathrm{a}$ \\
\hline \multicolumn{3}{|l|}{ Manure*Rotation } \\
\hline $\mathrm{M} * 4-\mathrm{yr}$ & $11.3 \pm 1.5$ & $9.1 \pm 1.7$ \\
\hline$M * 7-y r$ & $9.8 \pm 1.6$ & $9.4 \pm 0.9$ \\
\hline $\mathrm{U}^{* 4-\mathrm{yr}}$ & $12.0 \pm 1.3$ & $8.1 \pm 1.6$ \\
\hline $\mathrm{U}^{* 7-\mathrm{yr}}$ & $11.4 \pm 1.7$ & $8.5 \pm 1.3$ \\
\hline Grand Mean & 11.1 & 8.8 \\
\hline & \multicolumn{2}{|c|}{$\operatorname{Pr}>F$} \\
\hline Block & 0.1886 & 0.1648 \\
\hline Composted Manure & 0.0070 & 0.0114 \\
\hline Rotation & 0.0095 & 0.3295 \\
\hline Rotation*Crop & 0.2130 & 0.9561 \\
\hline
\end{tabular}

*Letters show significance at $\alpha=0.1$ within column.

\begin{tabular}{|l|c|c|}
\hline \multicolumn{3}{|c|}{ 2014 WA-MWD } \\
\hline \multicolumn{1}{|c|}{ Treatment } & $\mathrm{A}=4-\mathrm{yr}$ & $\mathrm{B}=7-\mathrm{yr}$ \\
\hline & & \\
\hline Composted Manure & & \\
\hline $\mathrm{M}$ & $5.4 \mathrm{a}$ & $5.8 \mathrm{a}$ \\
\hline $\mathrm{U}$ & $5.3 \mathrm{a}$ & $5.0 \mathrm{~b}$ \\
\hline Crop & & \\
\hline & & $5.5 \mathrm{a}$ \\
\hline $\mathrm{C}$ & $5.1 \mathrm{~b}$ & $5.3 \mathrm{a}$ \\
\hline
\end{tabular}




\begin{tabular}{|c|c|c|}
\hline Manure*Crop & & \\
\hline $\mathrm{C} * \mathrm{M}$ & $5.1 \pm 0.6$ & $5.7 \pm 0.5$ \\
\hline $\mathrm{K}^{*} \mathrm{M}$ & $5.8 \pm 0.2$ & $5.9 \pm 0.2$ \\
\hline $\mathrm{C} * \mathrm{U}$ & $5.0 \pm 0.7$ & $5.3 \pm 0.8$ \\
\hline $\mathrm{K} * \mathrm{U}$ & $5.6 \pm 0.7$ & $4.7 \pm 1.2$ \\
\hline Grand Mean & 5.4 & 5.4 \\
\hline & \multicolumn{2}{|c|}{$\operatorname{Pr}>F$} \\
\hline Block & 0.5727 & 0.0662 \\
\hline Composted Manure & 0.3914 & 0.0002 \\
\hline Crop & 0.0002 & 0.2407 \\
\hline Manure*Crop & 0.9036 & 0.0660 \\
\hline
\end{tabular}

*Letters show significance at $\alpha=0.1$ within column.

\begin{tabular}{|c|c|c|}
\hline \multicolumn{3}{|c|}{2014 WA: MWD (mm) } \\
\hline Treatment & Corn & Kale \\
\hline \multicolumn{3}{|l|}{ Composted Manure } \\
\hline $\mathrm{M}$ & $5.4 \mathrm{a}$ & $5.8 \mathrm{a}$ \\
\hline $\mathrm{U}$ & $5.1 \mathrm{a}$ & $5.2 \mathrm{~b}$ \\
\hline \multicolumn{3}{|l|}{ Rotation Cycle } \\
\hline $4-y r$ & $5.1 \mathrm{~b}$ & $5.7 \mathrm{a}$ \\
\hline $7-\mathrm{yr}$ & $5.5 \mathrm{a}$ & $5.3 b$ \\
\hline \multicolumn{3}{|l|}{ Manure*Rotation } \\
\hline$M * 4-y r$ & $5.1 \pm 0.6$ & $5.8 \pm 0.2$ \\
\hline $\mathrm{M} * 7-\mathrm{yr}$ & $5.7 \pm 0.5$ & $5.9 \pm 0.2$ \\
\hline $\mathrm{U} * 4-\mathrm{yr}$ & $5.0 \pm 0.7$ & $5.6 \pm 0.7$ \\
\hline $\mathrm{U}^{*} 7-\mathrm{yr}$ & $5.3 \pm 0.8$ & $4.7 \pm 1.2$ \\
\hline Grand Mean & 5.3 & 5.5 \\
\hline & \multicolumn{2}{|c|}{$\operatorname{Pr}>\mathrm{F}$} \\
\hline Block & 0.1127 & 0.0702 \\
\hline Composted Manure & 0.1111 & 0.0006 \\
\hline Rotation & 0.0095 & 0.0321 \\
\hline Rotation*Crop & 0.3548 & 0.0071 \\
\hline
\end{tabular}

*Letters show significance at $\alpha=0.1$ within column.

\section{Appendix C}

Table C1a: MWD data for aggregate stability- Transition from Crops into Grass Component, and Grass Component into Crops as affected by Manure Input

Dry Aggregate Stability (MWD) 2014 (mm)

Treatment

\begin{tabular}{l|l}
$\mathrm{M}$ & $\mathrm{U}$ \\
\hline
\end{tabular}




\begin{tabular}{|r|c|c|}
\hline & & \\
\hline Crop (Crop to Grass Transition) & & \\
\hline Kale & $9.4 \mathrm{a}$ & $8.5 \mathrm{~b}$ \\
\hline O5 & $9.4 \mathrm{a}$ & $10.0 \mathrm{a}$ \\
\hline & & 9.2 \\
\hline Grand Mean & 9.4 & \multicolumn{2}{|c|}{ Pr>F } \\
\hline Block & 0.0002 & 0.1640 \\
\hline Crop & 0.9177 & 0.0121 \\
\hline & & \\
\hline Crop (Grass to Crop Transition) & & $9.3 \mathrm{~b}$ \\
\hline O7 & $9.3 \mathrm{a}$ & $11.4 \mathrm{a}$ \\
\hline Corn & $9.8 \mathrm{~b}$ & 10.3 \\
\hline Grand Mean & 9.5 & \\
\hline & \multicolumn{2}{|c|}{ Pr>F } \\
\hline Block & 0.0994 & 0.2896 \\
\hline Crop & 0.3591 & 0.0012 \\
\hline
\end{tabular}

*Letters show significance at $\alpha=0.1$ within column.

Table C1b Transition from Crops into Grass Component, and Grass Component into Crops as affected by Manure Input

\begin{tabular}{|c|c|c|}
\hline \multicolumn{3}{|c|}{ Wet Aggregate Stability (MWD) 2014 (mm) } \\
\hline Treatment & $\mathrm{M}$ & $\mathrm{U}$ \\
\hline \multicolumn{3}{|l|}{ Crop (Crop to Grass Transition) } \\
\hline Kale & $5.9 \mathrm{a}$ & $4.7 \mathrm{a}$ \\
\hline $\mathrm{O} 5$ & $5.5 b$ & $5.3 \mathrm{a}$ \\
\hline Grand Mean & 5.7 & 5.0 \\
\hline & \multicolumn{2}{|c|}{$\mathrm{Pr}>\mathrm{F}$} \\
\hline Block & 0.5346 & 0.3853 \\
\hline Crop & 0.0051 & 0.1006 \\
\hline \multicolumn{3}{|l|}{ Crop (Grass to Crop Transition) } \\
\hline $\mathrm{O} 7$ & $5.8 \mathrm{a}$ & $5.9 \mathrm{a}$ \\
\hline Corn & $5.7 \mathrm{a}$ & $5.3 b$ \\
\hline Grand Mean & 5.8 & 5.6 \\
\hline & \multicolumn{2}{|c|}{$\operatorname{Pr}>F$} \\
\hline Block & 0.2035 & 0.8232 \\
\hline Crop & 0.5143 & 0.0119 \\
\hline
\end{tabular}

*Letters show significance at $\alpha=0.1$ within column. 